UNIVERSIDADE DE SÃO PAULO

Instituto de Psicologia

Departamento de Psicologia Social e do Trabalho

\title{
DRAGÕES: \\ GÊNERO, CORPO, TRABALHO E VIOLÊNCIA NA FORMAÇÃO DA IDENTIDADE ENTRE TRAVESTIS DE BAIXA RENDA
}

MARCOS ROBERTO VIEIRA GARCIA

São Paulo

2007 
UNIVERSIDADE DE SÃO PAULO

Instituto de Psicologia

Departamento de Psicologia Social e do Trabalho

\title{
DRAGÕES:
}

\section{GÊNERO, CORPO, TRABALHO E VIOLÊNCIA NA FORMAÇÃO DA IDENTIDADE ENTRE TRAVESTIS DE BAIXA RENDA}

\begin{abstract}
Tese apresentada ao Programa de Pós-Graduação em Psicologia Social do Instituto de Psicologia da Universidade de São Paulo, como parte dos requisitos para obtenção do título de Doutor em Psicologia Social
\end{abstract}

Orientadora: Profa. Dra. Yvette Piha Lehman.

São Paulo 


\author{
UNIVERSIDADE DE SÃO PAULO \\ Instituto de Psicologia \\ Departamento de Psicologia Social e do Trabalho
}

\begin{abstract}
DRAGÕES:
GÊNERO, CORPO, TRABALHO E VIOLÊNCIA NA FORMAÇÃO

DA IDENTIDADE ENTRE TRAVESTIS DE BAIXA RENDA
\end{abstract}

Doutorando: Marcos Roberto Vieira Garcia

Orientadora: Profa. Dra. Yvette Piha Lehman.

\title{
BANCA EXAMINADORA
}

(Nome e assinatura)

(Nome e assinatura)

(Nome e assinatura)

(Nome e assinatura)

(Nome e assinatura)

Dissertação defendida e aprovada em: 
Para minha "ohana"

Lê, Nã e Lu, com todo o meu amor 


\title{
Agradecimentos
}

\author{
À Professora Yvette Piha Lehman, pelas elucidativas discussões durante \\ todo meu percurso;
}

Às Professoras Vera Paiva e Marília Carvalho, pelas sugestões apresentadas no Exame de Qualificação;

Aos amigos e colegas Luís Lima, Roberto MacFadden, Marcelo Ribeiro, Conrado Ramos, João Carvalho, Luís Galeão e Iraí Carone, pelas discussões de várias idéias aqui expostas em alguns Congressos;

Aos inúmeros amigos e colegas com os quais tive o prazer de trocar idéias a respeito dos temas desta tese;

À Nalva e Cecília, por suportarem com bom humor as dezenas de dúvidas e encaminhamentos burocráticos;

À minha esposa e companheira Letícia, pelo apoio e por ter aberto mão de muita coisa que poderíamos ter feito juntos em todo este tempo;

Às minhas filhas Ananda e Luara, pelos mesmos motivos acima e pelo silêncio precioso nos momentos em que mais precisei;

À todos os amigos e familiares pelo incentivo;

À CAPES, pela bolsa concedida;

E, finalmente, a todas as travestis do Grupo, que, de uma forma ou de outra, são também um pouco autoras desta tese.

"De tudo que é nego torto, 
Do mangue, do cais do porto,

Ela já foi namorada.

O seu corpo é dos errantes,

Dos cegos, dos retirantes,

É de quem não tem mais nada.

Dá-se assim desde menina,

Na garagem, na cantina;

Atrás de tanque, no mato.

É a rainha dos detentos,

Das loucas, dos lazarentos,

Dos moleques do internato.

E também vai amiúde,

Com os velhinhos sem saúde

$E$ as viúvas sem porvir.

Ela é um poço de bondade,

E é por isso que a cidade,

Vive sempre a repetir:

Joga pedra na Geni, joga pedra na Geni,

Ela é feita pra apanhar, ela é boa de cuspir,

Ela dá pra qualquer um, maldita Geni ! ’

Chico Buarque, em "Geni e o Zepelim"

"Nada é mais lamentável numa mulher ou num homem do que ter orgulho do seu sexo"

(Virginia Woolf, na voz $d(a)$ personagem Orlando) 


\section{SUMÁRIO}

INTRODUÇÃO

Método 9

Cuidados Éticos $\quad 13$

$\begin{array}{ll}\text { IDENTIDADE } & 15\end{array}$

Travestismo e transexualismo na Psiquiatria e Psicologia $\quad 15$

O conceito de Identidade 22

$\begin{array}{lr}\text { Identidade entre transgêneros } & 27\end{array}$

Panorama histórico do surgimento das travestis 31

A identidade travesti 38

Identidade como colcha de retalhos ("patchwork") 41

GÊNERO 44

Origem social das travestis $\quad 50$

Infância e Adolescência 53

O "viado" ("bicha")

$\begin{array}{ll}\text { Tornando-se travesti } & 59\end{array}$

O "marido" e a "mulher submissa" 66 
O "vício"

$\begin{array}{ll}\text { CORPO } & 75\end{array}$

$\begin{array}{ll}\text { Transgêneros e corpo } & 81\end{array}$

Os Hormônios $\quad 85$

$\begin{array}{ll}\text { O Silicone } & 88\end{array}$

A "mulher super-sedutora" $\quad 92$

$\begin{array}{ll}\text { A“neca” (pênis) } & 97\end{array}$

A “Tia” (AIDS) 101

$\begin{array}{ll}\text { TRABALHO } & 105\end{array}$

O "Trottoir" 109

A "puta" 113

Travestis como trabalhadoras informais autônomas 116

$\begin{array}{ll}\text { Os Clientes } & 129\end{array}$

O "malandro" 132

$\begin{array}{lr}\text { VIOLÊNCIA } & 141\end{array}$

Os “alibãs” (polícia) 143

Roubos e furtos 146

A "pedra" (crack) 151

$\begin{array}{ll}\text { A prisão } & 154\end{array}$

O "bandido" 157

$\begin{array}{ll}\text { CONCLUSÃO } & 161\end{array}$ 
REFERÊNCIAS BIBLIOGRÁFICAS 


\section{RESUMO}

Garcia, Marcos Roberto Vieira. "Dragões": gênero, corpo, trabalho e violência na formação da identidade entre travestis de baixa renda. São Paulo, 2007, 148p. Tese (Doutorado). Instituto de Psicologia. Universidade de São Paulo.

O presente estudo se iniciou a partir de uma intervenção de cerca de quatro anos, na área da promoção de saúde, voltada a um grupo de travestis de baixa renda, que realizava encontros em uma instituição pública na região central de São Paulo. O método de pesquisa utilizado foi o da observação participante ativa, priorizando-se o caráter interativo e dialógico na obtenção dos dados. Buscou-se investigar a constituição da identidade social entre as referidas travestis, pela descrição e análise de quatro eixos fundamentais para o entendimento de seu universo - gênero, corpo, trabalho e violência - na perspectiva de transcender o privilégio dado à categoria gênero nos estudos existentes sobre travestis. Procurou-se submeter cada um destes eixos a uma análise social ampliada e referida à realidade brasileira. A partir de uma abordagem crítica à categoria "identidade", foi proposto o entendimento desta, em relação ao grupo estudado, como uma "colcha de retalhos" ("patchwork"), formada a partir da assimilação de fragmentos de diferentes identidade sociais presentes em nossa sociedade. Considerou-se que as principais identidades incorporadas pelas travestis estudadas foram as da "mulher submissa", da "puta" e da "mulher super-sedutora", no campo da feminilidade e as do "viado", do "malandro" e do "bandido", no campo da masculinidade. A “identidade travesti” resultante mostrou não apenas a ambiguidade masculino/feminina, mas também contradições e tensões entre as próprias identidades femininas - e masculinas - incorporadas. 


\begin{abstract}
Garcia, Marcos Roberto Vieira. "Dragões" ("Dragons"): gender, body, work and violence in the identity formation among low-income brazilian travestis..São Paulo, 2007, 148p. PHD Thesis. Instituto de Psicologia. Universidade de São Paulo.

This study had its origin in a four-year health promotion work, directed to low-income travestis, within a public health institution in the central area of São Paulo, Brazil. The research method comprised active participant observation, with interactive, and dialogical data collection. The social identity formation among these travestis was investigated by description and analysis of four axis; gender, body, work, and violence, each of them fundamental for the understanding of their universe, attempting to transcend the status given to gender category in other studies with this population. Each one of these axis were submitted to a wider social analysis and referred to the current situation in Brazil. The identity category was subjected to a critical analysis and was proposed, in the referred group, the understanding of identity as a "patchwork", built by the assimilation of different identity fragments that are common in Brazilian society. The major identities incorporated by the studied travestis were, in the field of feminility, the "submissive woman", the "puta" ("whore"), and the "seductress". In the field of masculinity the "viado" ("queer"), the "malandro" ("rogue"), and the "bandido" ("bandit"). The resultant travesti identity showed not only a masculine and/or feminine ambiguity, but also contradictions amongst the incorporated feminine identities, in the same way as the masculine ones.
\end{abstract}




\section{INTRODUÇÃO}

Este estudo pretende refletir sobre a constituição da identidade entre travestis de baixa renda. Tem como subsídio um trabalho de intervenção, realizado durante pouco mais de 4 anos, de 1999 a 2003. Tal trabalho correspondeu ao acompanhamento de um grupo de travestis, que se encontrava semanalmente em uma instituição pública voltada à Saúde Mental, localizada na região central de São Paulo.

O Grupo ${ }^{1}$ em questão tinha a finalidade de propiciar reflexão a respeito de diversos aspectos relacionados à vida das travestis que o frequentavam, tais como a prostituição, a competição entre as mesmas, a violência policial, o sexo seguro, a moradia, o enfrentamento do preconceito, o abuso de drogas, etc. No contato semanal com estas todo um universo de vivências e significações foi sendo aos poucos revelado, passando algumas destas a serem objeto de minhas reflexões, que se aprofundaram a partir do contato com algumas obras relacionadas ao tema.

O Grupo teve início com uma prática de distribuição de preservativos realizada por uma Assistente Social da referida instituição. Tal prática era individualizada e foi sendo divulgada boca-a-boca entre travestis. Com a entrada de um psicólogo na instituição, com experiência prévia de trabalho com esta população ${ }^{2}$, formou-se o Grupo em questão. Com a saída deste psicólogo fui convidado a ajudar na coordenação do mesmo $^{3}$. Nos primeiros dois anos tal função foi compartilhada com uma enfermeira e depois segui sozinho, por falta de profissionais técnicos adequados e disponíveis para o trabalho.

\footnotetext{
1 Serão omitidos o nome do Grupo e da instituição como forma de resguardar a identidade das participantes.

${ }^{2}$ Refiro-me a Marcus de Amorim Moraes, que já havia trabalhado na Casa Brenda Lee, instituição voltada ao tratamento de travestis com AIDS.

${ }^{3}$ Permaneci como funcionário da referida instituição no período de 1997 a 2004.
} 
Neste período de quatro anos de intervenção, aproximadamente duzentas travestis passaram pelo Grupo. Entre elas, travestis de diferentes estilos, níveis de renda e pontos de prostituição. Grande parte das mesmas, porém, participou de poucos encontros. As mais constantes nos encontros eram as de baixa renda, que trabalhavam na avenida Cruzeiro do Sul, rua Voluntários da Pátria e na região da Santa Efigênia e da Luz. Os locais de moradia eram bastante variados, embora uma parcela significativa morasse em pensões para travestis existentes próximas aos locais de prostituição.

Os encontros do Grupo eram semanais e abertas à participação de quem quisesse vir. Além das travestis, compareciam com certa frequência, embora em número bem menor, alguns companheiros delas ("maridos"), michês e prostitutas que mantinham relações de amizade com as mesmas. Nas reuniões eram feitas regularmente distribuição gratuita de preservativos. Estes eram disponibilizados pelo Ministério da Saúde, segundo normas específicas ${ }^{4}$. Tal distribuição era certamente um dos motivos para o comparecimento, embora não o único. Muitas travestis eram criticadas constantemente pelas colegas quando mostravam pouco compromisso com as discussões que ali se davam.

A frequência média nos encontros era por volta de 15 pessoas, embora este número fosse bastante inconstante - houve situações onde compareceram mais de quarenta pessoas e outras onde apenas duas fizeram parte. A dinâmica de interação dos mesmos era basicamente verbal, embora em alguns casos fossem propostas atividades de interação grupal para intervenções particulares. Por vezes, o Grupo também recebia convidados para discorrerem sobre temas específicos. Aos finais de ano, as travestis promoviam uma festa de encerramento.

O funcionamento do Grupo foi orientado pelos princípios da promoção de saúde. Esta tem sido descrita como um modelo de atenção à saúde que extrapola a assistência médica, resgatando a concepção de saúde como um produto social (Sícoli e Nascimento, 2003; Souza e Grundy, 2004). Entre os componentes importantes deste processo estão a disseminação de informações e a educação, de forma a promover a capacitação dos indivíduos e comunidades para assumirem maior controle sobre os

\footnotetext{
${ }^{4}$ Em 2002, a referência era de 30 preservativos por semana para cada profissional do sexo.
} 
fatores pessoais, sócio-econômicos e ambientais que afetam a saúde (WHO, 1998). Subjacente a essa abordagem, estão as concepções de empoderamento e da busca pela emancipação e autonomia dos grupos sociais, termos que frequentemente se superpõe nas diferentes ciências humanas que abordam as gestões de práticas comunitárias. Para Paiva (1996), que reflete sobre estas concepções no campo dos direitos sexuais e reprodutivos, é necessária a crítica no interior das mesmas tanto às propostas de intervenção universalizantes quanto às noções individualizantes de sujeito às vezes presentes (p. 225-9).

Se a promoção de saúde pressupõe a prevenção, baseada na concepção de risco ou da probabilidade de se tornar doente, também a transcende na medida em que o foco se desloca da doença para o dos fatores sócio-culturais que a atravessam, fatores estes que serão melhor descritos no transcorrer deste estudo. No caso das travestis investigadas, a insuficiência das abordagens centradas apenas na prevenção foi, desde o início, evidente, uma vez que eram constantes as reclamações a respeito de "não se aguentar mais falar de doença" quando alguma estratégia deste tipo era proposta ${ }^{5}$.

À promoção de saúde, foi frequentemente associada uma intervenção baseada nas estratégias de "redução de danos". Surgida no campo da dependência em relação a substâncias psicoativas, a redução de danos corresponde a "uma tentativa de minimizar as consequências adversas do consumo de drogas do ponto de vista da saúde e dos seus aspectos sociais e econômicos sem, necessariamente, reduzir seu consumo" (WODAK, 1998, pg 55). Tal proposta foi inicialmente disseminada em práticas como a substituição de heroína por metadona, entre usuários de heroína, e a distribuição de seringas para usuários de drogas injetáveis, grupo profundamente atingido pela epidemia da AIDS. Ultrapassando o campo da dependência química, a redução de danos passou a ser defendida como um princípio aplicável a outras modalidades de intervenção em saúde pública, dentre elas a relacionada ao uso de

\footnotetext{
${ }^{5}$ É possível se pensar aqui em um movimento de resistência deste segmento da população às políticas de prevenção de DST/AIDS no Brasil.
} 
hormônios e silicone industrial entre travestis ${ }^{6}$. No caso específico do Grupo, a preocupação em se respeitar as escolhas das travestis, implícita na abordagem de redução de danos, manifestou-se não somente com relação ao uso do hormônio ou silicone, ao consumo de substâncias psicoativas ou ao sexo seguro, mas também em outros temas, como os relacionados aos conflitos pelos melhores "pontos" de prostituição e às práticas de extorsão dos clientes.

A proposta de desenvolvimento da consciência grupal e da busca por transformações concretas foi objeto de constante preocupação nos encontros. Com relação aos resultados obtidos neste sentido, houve certamente vários momentos de mobilização do Grupo para a resolução de conflitos específicos, que oscilavam com outros onde era predominante a passividade frente a busca por mudanças. Isso ocorria certamente pelo seu próprio caráter aberto e pela presença intermitente de algumas travestis que exerciam alguma liderança entre suas colegas. Embora o ideal de emancipação, constantemente desejado pelas integrantes na materialização de uma "Associação de Travestis", não tenha sido alcançado, a experiência de discussão da realidade vivenciada por elas, em uma relação de diálogo constante comigo e com os demais técnicos que participaram dos encontros, foi certamente enriquecedora para a construção de uma maior aceitação por sua própria condição entre as travestis presentes e para o fortalecimento dos laços de união entre muitas delas.

O Grupo passou por um processo de esvaziamento e acabou se desfazendo em 2003. Uma das razões para este término foi meu afastamento parcial da instituição por um ano e meio, devido a uma licença para tratar de assuntos pessoais, período em que continuei acompanhando o mesmo voluntariamente, em reuniões quinzenais. Tal processo foi acompanhado por uma dificuldade em se estabelecer um fluxo de informações adequado na Instituição com respeito às datas e horário dos encontros, tendo em vista algumas modificações profundas pelas quais a Instituição passou no mesmo período. Ocorreu também uma disputa bastante violenta por pontos de

\footnotetext{
${ }^{6}$ Em relação a travestis, é provável que o primeiro documento que foi inspirado na proposta de redução de danos tenha sido a cartilha "Silicone: Redução de Danos para Travestis", produzida pelo Grupo Gay da Bahia. A proposta passou a ser pouco a pouco disseminada por diversas ONGs e serviços públicos de atendimento a travestis. Recentemente foi adotada como política oficial junto a essa população pela Prefeitura de Campinas - SP.
} 
prostituição na região da Avenida Cruzeiro do Sul, que colocou em conflito algumas integrantes do Grupo, as quais deixaram de comparecer ao mesmo. Além disso, a travesti que assumia com maior frequência a posição de liderança entre elas acabou se afastando, ao assumir um cargo de agente comunitária em uma outra instituição pública da cidade de São Paulo.

As travestis de baixa renda se auto-denominavam e se referiam umas às outras de várias maneiras. Optamos por utilizar o termo "dragão" para designá-las no título deste estudo. Tal termo, utilizado coloquialmente em nosso idioma para designar uma pessoa considerada feia, se referia, entre elas, à aparência física pouco feminina, que não correspondia a um padrão estético hegemônico e/ou que mostrava sinais de envelhecimento, como rugas e queda de cabelos. Esse último termo era mais comumente utilizado como auto-representação do que os demais, como "penosa" ou "varejeira", daí ser aqui apropriado para nomear tal segmento da população travesti. Ao termo "dragão" contrasta o termo "deusa", referência à travesti de aparência mais feminina, mais jovem, com traços que muitas vezes mostram ascendência européia. São "deusas" ${ }^{8}$ as diversas ícones travestis (Roberta Close, Thelma Lipp, etc) e aquelas com frequente exposição na mídia, contribuindo para a formação de uma representação hegemônica das mesmas em nossa sociedade. Da mesma forma, as travestis de baixa renda tem menor visibilidade nos movimentos associativos, pouco participando dos mesmos ${ }^{9}$.

Considerar a especificidade das travestis de baixa renda implica em filiar este estudo não somente ao campo de estudos de gênero e sexualidade, como também ao dos estudos sobre trabalho e desigualdade social. É importante esta consideração

\footnotetext{
${ }^{7}$ Outra razão para a escolha deste termo no título de nosso estudo é a associação que sugere com a figura do dragão, presente em diversas mitologias e representada de diferentes maneiras. Essa figura tem sua imagem construída a partir da incorporação de elementos de origem distinta, como, por exemplo, de diversos animais. Daí a analogia com a tentativa de fusão de diversos fragmentos identitários, que propomos como algo fundamental para o entendimento da formação da identidade entre as travestis de baixa renda.

${ }^{8}$ Pelúcio (2005b) cita os termos "tops" ou "européias" como comuns nos segmentos de alta renda em São Paulo.

${ }^{9}$ As travestis investigadas, por exemplo, não participavam - e por vezes até desconheciam - a Parada Gay da São Paulo, que congrega diversos segmentos do universo homoerótico.
} 
porque pouco espaço tem sido dado às dimensões trabalho e renda como fundamentais no entendimento do universo das travestis ${ }^{10}$. A desconsideração das diferenças de segmento de renda se torna ainda mais evidente em uma comparação com os estudos sobre a prostituição feminina, onde esta dimensão é fartamente discutida e analisada. É possível que tal fato se deva a uma certa separação historicamente estabelecida entre os campos de estudo de gênero e de classe social ${ }^{11}$. Da mesma forma há, no caso das travestis, uma evidente concentração de estudos em linhas de pesquisa antropológicas, em detrimento de estudos sociológicos, onde tal dimensão é objeto de preocupação mais intensa, e de outras disciplinas.

Recentemente mais atenção tem sido dada à questão do trabalho e das diferenças de renda em estudos sobre o homoerotismo. Os recentes trabalhos de Trindade (2004) e Andrade (2005), por exemplo, mapeiam o universo homoerótico em São Paulo e apontam com clareza a constituição nesta cidade de demarcações claras de regiões frequentadas por diferentes perfis de homossexuais, de acordo com a disponibilidade financeiras dos mesmos. A consideração a respeito do trabalho e da renda em nosso estudo mostra-se ainda mais necessária se observarmos o progressivo descolamento dos locais de moradia e de prostituição travesti em relação às maiores áreas de concentração de lazer da população homossexual de São Paulo - Centro e Jardins. Embora tal ponto seja considerado em extensão mais adiante, é importante adiantar aqui que parece haver um deslocamento de travestis pela cidade, que se dá em função da busca por clientes mais do que por locais de aceitação com relação a sua condição.

Em relação à sequência a ser desenvolvida, este estudo está organizado em cinco partes. A primeira é dedicada a uma reflexão sobre o conceito de identidade e sobre como esta se constitui entre as travestis pesquisadas, partindo-se da idéia de que sua identidade é construída a partir da apropriação de diferentes modelos de

\footnotetext{
10 Um notável exceção é o trabalho de Perlongher (1987a), que ao abordar michês desenvolve longamente as divisões existentes na região central de São Paulo, de acordo com o segmento de renda. Tal estudo refere-se também, ainda que tangencialmente, à prostituição travesti.

11 A primazia da categoria gênero em detrimento das outras tem sido criticada por diversos autores. Connell (1997) considera, neste sentido, que, para se entender o gênero, devemos ir constantemente além dele próprio (p. 38).
} 
masculinidades e feminilidades presentes na sociedade brasileira. As quatro seguintes são dedicadas a cada um dos eixos que consideramos relevantes para o entendimento da realidade das mesmas. Na segunda, é abordada a relação das travestis com o gênero, ou seja, o posicionamento frente ao sistema de gêneros masculino/feminino hegemônico nas sociedades ocidentais. Na terceira, a relação com o corpo, tornado cada vez mais maleável e esculpido pelas novas tecnologias de transformação corporal. Na quarta é abordada a relação das travestis com o trabalho, ou seja, a forma pela qual a prostituição como atividade predominante de renda se relaciona com diversos aspectos de sua subjetividade. Na quinta, finalmente, é descrita e analisada a violência presente de diversas formas em suas vivências.

Considerar as travestis a partir dos eixos gênero, corpo, trabalho e violência não significa afirmar que os mesmos "esgotam" a possibilidade de entendimento de seu universo. Pode-se dizer que tais eixos não são nem mesmo onipresentes: há várias travestis que não se prostituem ou não são hormonizadas/siliconadas ou se colocam de forma heterogênea em relação ao sistema de gêneros. Cabe ressaltar, finalmente, que outros temas, como, por exemplo, a AIDS e o consumo de substâncias ilícitas tem também um lugar importante neste estudo, embora não sejam tratados em capítulos específicos.

Há um número pequeno, porém não desprezível, de estudos na área das Ciências Humanas que envolvem trabalho de campo com travestis no Brasil. As descrições e interpretações do universo das travestis de baixa renda em São Paulo será cotejada com as de alguns destes estudos. Entre eles, os de Hélio Silva (1993), com trabalho de campo no Rio de Janeiro, de Neusa Oliveira (1994) e de Kulick (1998), em Salvador, de Marcelo Oliveira (1997), em Florianópolis, de Florentino (1998) e de Benedetti (2000), com trabalho de campo em Porto Alegre, de Vale (2000), em Fortaleza, de Ferreira (2003), em Belém, de Pelúcio (2005a, 2005b e 2005c), em São Paulo e de Araújo Jr (2006) em Londrina ${ }^{12}$.

\footnotetext{
${ }^{12}$ Há também alguns trabalhos aos quais não tive acesso: de Fontanele (1999), em Fortaleza e de Patrício (2002), em Campina Grande.
} 
Com exceção dos estudos de Pelúcio citados, todos os outros se voltaram majoritariamente a travestis de baixa renda, a julgar pelas descrições que fazem das mesmas. Mesmo assim, o fator renda não é tratado como um diferencial em relação ao conjunto das travestis como um todo, uma vez que suas características são apresentadas como intrínsecas às travestis como segmento social ${ }^{13}$. Por causa da seleção de uma população predominantemente de baixa renda, há uma grande concordância entre diversas características das travestis descritas nestas pesquisas e as de São Paulo, observadas no Grupo aqui estudado. Tal constatação se relaciona sem dúvida ao fato de que há uma grande circulação das mesmas pelas grandes cidades brasileiras. É muito comum o trânsito entre duas grandes metrópoles (São Paulo e Rio de Janeiro), metrópoles regionais (Belo Horizonte, Porto Alegre, Salvador, Recife, Fortaleza, etc) e as demais cidades de grande e médio porte no Brasil, sem contar o movimento sazonal Brasil/Europa, acessível às travestis de segmentos de renda mais altos. Tal movimento se deve a diversos fatores: à busca de um novo mercado, que possa proporcionar maior ganho financeiro na prostituição ${ }^{14}$, às ameaças sofridas em um determinado local, por parte dos clientes, policiais ou outras travestis, ao desejo de estar em locais onde se possa transformar mais facilmente o corpo, principalmente via silicone - o que explica a migração para as metrópoles, ao desejo de se manter longe da dependência relacionada a alguma substância ilícita ${ }^{15}$, à necessidade de tratamento médico, principalmente para as que tem AIDS e que buscam os locais onde há melhor atendimento, dentre outros.

\footnotetext{
${ }_{13}$ Benedetti (2000) observa a diferença de renda, mas considera que as travestis de segmentos altos e baixos tem um ideário homogêneo, apresentando valores morais e estéticos semelhantes (p. 31-2). Em outro trecho de sua obra, contudo, aponta uma hierarquia na ocupação de territórios na cidade, considerando que

"os clientes mais pobres, os caminhoneiros, os que não tem carro e os que são mais feios compartilham espaços com travestis que são mais velhas, que vivem em situação de maior pobreza e que fazem investimentos(subjetivos e objetivos) menos apurados na fabricação do feminino, ao passo que clientes com mais dinheiro, com veículos próprios e que pertencem a um estrato social mais elevado frequentam as zonas ocupadas por travestis mais jovens, que realizam grande investimento na construção do feminino, com gosto estético atualizado com as tendências da moda, etc”. (p. 116)
}

14. A referência à vantagem se ser “carne nova” era frequentemente citada pelas travestis nos encontros. Movimento análogo parece ocorrer na prostituição feminina.

${ }_{15}$ Algumas travestis pesquisadas, usuárias de crack, buscavam passar algum tempo no Rio de Janeiro ou em outro local onde não existisse a mesma disponibilidade da substância, como forma de evitar seu uso. 
Se a descrição da vida, cotidiano e linguagem das travestis são convergentes, o mesmo não se pode dizer das interpretações dadas pelos autores citados, como veremos mais adiante. Com exceção do trabalho de Hélio Silva (1993), os demais se dedicam muito mais à descrição do universo das travestis do que a tentativas de interpretação do mesmo ou de relacioná-lo aos de outros grupos sociais. Há uma série de dissensos nestes estudos, referentes à forma como é interpretada a constituição da identidade entre elas, que serão abordados no próximo capítulo.

\section{Método}

A coordenação do Grupo citado demandou de minha parte uma compreensão específica do universo das travestis, construída por leituras e, principalmente, pelo compartilhar das discussões estabelecidas nos encontros. Após aproximadamente um ano exercendo esta função, surgiu a idéia de valer-me de tal experiência para a realização de um estudo sobre esta população. Houve desta forma, em um primeiro momento informalmente e em um segundo formalmente, uma dupla função por mim exercida frente ao Grupo: a de coordenador dos encontros e a de pesquisador do universo das travestis.

Após a idéia de realização de uma pesquisa com a população travesti, foi iniciado o registro sistemático dos encontros, o que era feito sempre após o encerramento dos mesmos e de forma a se priorizar a descrição dos elementos mais relevantes. Seguindo-se esta estratégia, cerca de 100 páginas de anotações foram conservadas referentes ao período de existência do Grupo. Grande parte delas referem-se a situações-modelo vivenciadas, ou seja, a histórias que se repetiam com frequência entre as travestis pesquisadas. Em alguns casos, referem-se a situações menos comuns, importantes de serem ressaltadas para se evitar a excessiva generalização muitas vezes feita sobre o universo vivencial das travestis.

A proposta de subsidiar este estudo com estes dados pressupõe a valorização do contexto em que as informações foram obtidas. A qualidade dos dados obtidos é muitas vezes superior quando se assume o contexto relacional e interativo em sua 
obtenção. Os encontros, estruturados a partir de conversas entre (muitas) travestis e (poucos) técnicos, possibilitaram um riqueza de diálogo indispensável para se penetrar de forma mais aprofundada na realidade das mesmas. Inúmeras vezes os encontros tomaram direções inesperadas a partir das discussões entre as próprias travestis, trazendo dados jamais suspeitados por mim, seja na figura de coordenador do Grupo, seja na de pesquisador deste universo.

Embora houvesse a idéia inicial de utilização de entrevistas gravadas como um recurso adicional mais formal para a obtenção de dados para esta pesquisa, tal idéia foi abandonada justamente pelo fato dela não possibilitar a riqueza de dados que surge na situação de interação grupal. Pelo mesmo motivo, descartou-se a gravação dos encontros, uma vez que a maior fidedignidade dos dados não compensaria a quebra da espontaneidade dos discursos nesta situação. Isso ficou particularmente claro em uma ocasião onde o Grupo recebeu a visita de uma pesquisadora ${ }^{16}$, que conseguiu autorização delas para a gravação de um encontro. $O$ fato de ter sido gravado tornou-o completamente atípico: mudaram não só os assuntos e os discursos das travestis, como também a dinâmica de interação do grupo.

Tal proposta de investigação é constantemente referida nas Ciências Humanas pelo nome de observação participante. Esta teve suas origens na Sociologia (Escola de Chicago) e Antropologia (Malinowski) e é definida por Lofland e Lofland ${ }^{17}$ (apud May, 2004) como

\footnotetext{
“o processo no qual um investigador estabelece um relacionamento multilateral e de prazo relativamente longo com uma associação humana na sua situação natural com o propósito de desenvolver um entendimento científico daquela associação” (p. 177)
}

\footnotetext{
${ }^{16}$ Refiro-me à antropóloga canadense Natasha Prèvost

${ }^{17}$ LOFLAND, J. e LOFLAND, L. Analysing Social Settings: a guide to qualitative observation and analysis. Belmont, CA, Wadsworth, 1984
} 
Uma outra definição, próxima a esta, é dada por Schwartz e Schwartz ${ }^{18}$ (apud Haguette, 2000)

\footnotetext{
"Definimos a observação participante como um processo no qual a presença de um observador numa situação social específica é mantida para fins de investigação científica. O observador está em relação face a face com os observados, e, em participando com eles em seu ambiente natural de vida, coleta dados" ( p. 71):
}

Um dos aspectos importantes em relação a observação participante refere-se à necessidade de se estar "aberto" para o grupo ou comunidade que se está pesquisando, uma vez que envolve a entrada em universo no qual as pessoas já estão interpretando e entendendo seu ambiente. Em relação à minha inserção junto às travestis, tal necessidade foi bastante evidente desde o princípio, demandando uma necessidade até mesmo de "tradução" de determinados termos utilizados por elas com frequência ${ }^{19}$.

Outra necessidade frequente na observação participante é a da eliminação dos preconceitos e da busca por um entendimento empático frente ao ambiente social em questão. Isso significa um envolvimento maior do pesquisador, que compartilha não só das atividades, mas também dos processos subjetivos - interesses e afetos - do grupo pesquisado (Haguette, 2000). Tal processo nem sempre é fácil, uma vez que determinados grupos sociais, como certamente é o caso das travestis, questionam muitas vezes valores profundamente incutidos pelo pesquisador. Em alguns momentos estas dificuldades se manifestaram quando de minha participação no Grupo. Um dos pontos onde isto ficou particularmente evidente foi em relação à aceitação da prática de roubo ou furto de clientes, comum entre as travestis de baixa renda, tema que será abordado mais adiante. .

\footnotetext{
${ }^{18}$ SCHWARTZ, M. S e SCHWARTZ, C. G. Problems in Participan Observation. In: MCCALL, G.J. e SIMMONS, J. C. (orgs). Issues in Participant Observation, a text reader. Massachusetts, AddisonWesley Publishing Company, 1969.

19 As travestis utilizam uma linguagem específica, em grande parte derivada do iorubá, como forma de garantir uma certa proteção em relação ao que está sendo dito. Tal linguagem será abordada mais adiante.
} 
A metodologia da observação participante pressupõe também que a observação é sempre permeada pela teoria (May, 2004, p. 179). Desta forma, rompe-se definitivamente com qualquer possibilidade de coleta de dados "neutra". Como resposta à impossibilidade de se recorrer à evidência dos dados coletados como parâmetro para avaliar a qualidade da pesquisa, uma das possibilidades é a de se buscar uma inserção mais profunda junto ao grupo pesquisado, de forma a se obter dados mais significativos, permitindo interpretações mais elaboradas. Isso demanda inserções mais demoradas no campo de pesquisa e uma postura mais ativa por parte do pesquisador, elementos que estão intrinsecamente ligados. Essa modalidade de observação participante é denominada de "observação participante ativa" por Haguette (2000), que refere que a mesma acaba por assumir alguns elementos da pesquisa-participante, 0 que penso ter ocorrido neste estudo sobre travestis.

A pesquisa-participante ou pesquisa-ação tem como elemento central a participação da comunidade ou grupo pesquisados na construção conjunta do conhecimento (Thiollent, 2002, p. 14), o que não se pode afirmar que ocorreu no caso deste estudo. Certamente grande parte das reflexões a serem apresentadas mais adiante foram posteriores ao término do Grupo, fruto de leituras que permitiram novas interpretações dos dados. Por outro lado, exatamente por exercer o duplo papel de coordenador do mesmo e de pesquisador, uma série de elementos típicos da pesquisaparticipante estiveram presentes no momento de intervenção e de coleta de dados para esta pesquisa:

- a busca por uma relação horizontal com os sujeitos de pesquisa, marcada por uma interação dialógica, que prioriza ações, discussões e decisões coletivas. Há um envolvimento pessoal entre o pesquisador e aqueles que este investiga , uma vez que quando "o outro se transforma em uma convivência, a relação obriga que o pesquisador participe de sua vida, de sua cultura" (Brandão, 1987, pg 12).

- o estabelecimento de uma relação de respeito para com o grupo pesquisado, o que envolve a pressuposição de que os sujeitos pesquisados detém um conhecimento e uma forma de lidar com os acontecimentos do seu cotidiano que não pode ser condenada de antemão com errada e passível de modificação. Como afirma Thiollent 
(2002), o pesquisador deve procurar ter uma atitude de elucidação dos aspectos das situações apresentadas, sem imposição unilateral de suas concepções próprias.

- a postura de facilitação da superação dos conflitos existentes no grupo ao qual a pesquisa se dirige. Nesse sentido, presume-se que há a observação, participação, problematização e proposição de soluções, sem, contudo, haver a imposição da visão do pesquisador na situação específica. A busca de soluções coletivas aos problemas enfrentados como característica da pesquisa-ação é apontada, entre outros, por Oliveira e Oliveira (1985) e Gajardo (1987), que enfatizam que o pesquisador deve utilizar-se deste tipo de pesquisa como forma de favorecer a aquisição de um conhecimento e de uma consciência crítica do processo de transformação por parte do grupo que o vivencia.

\section{Cuidados éticos}

O trabalho de intervenção realizado teve como uma das preocupações centrais a possibilidade de livre frequência das travestis. Por ter como diretriz a aceitação de sua condição transgênero, não era solicitado a elas que se identificassem com seu nome de registro. Da mesma forma, as travestis não eram identificadas como "pacientes" da referida instituição de saúde, o que implicaria na necessidade de se ter um prontuário, demandando a apresentação de documentos de identificação.

O único registro de frequência era feito por um livro onde as travestis colocavam seu "nome de mulher" 20 . Tal registro era necessário, devido à distribuição de preservativos feita, o que demandava algum tipo de comprovação de frequência. Com o transcorrer do tempo, tal registro foi substituído por um registro feito pessoalmente por mim ou por alguma travesti, uma vez que observei um número significativo de travestis iletradas, que se constrangiam por não saber escrever o "nome de mulher".

\footnotetext{
${ }^{20} \mathrm{O}$ nome feminino adotado pelas travestis era comumente chamado de "nome de mulher" ou "nome de bicha”.
} 
A possibilidade de ir-e-vir aos encontros sem a necessidade de registro formal possibilitou também o comparecimento de travestis que tinham alguma preocupação em serem identificadas, especialmente as que eram procuradas judicialmente por algum crime praticado ou as que eram objeto de perseguição policial. Estas mesmas travestis mudavam também com constância seu "nome de mulher", como forma de fugir a uma possível identificação.

O contexto em que ocorreu o Grupo impossibilitou também a autorização formal das travestis para a realização deste estudo. As travestis eram informadas com frequência de que os encontros eram também objeto de trabalho de campo deste estudo, mas não houve a preocupação em formalizar seu consentimento, uma vez que isto implicaria um rompimento com a diretriz de funcionamento do Grupo, contrária à identificação das integrantes. Mesmo na ausência de tal impedimento, podemos considerar que tal preocupação teria sido inviável devido à própria dinâmica de interação dos encontros, uma vez que era permitida a entrada e a saída a qualquer momento.

Como cuidados éticos neste estudo, além da omissão do nome da instituição e do Grupo referidos, serão modificados seus "nomes de mulher" e as descrições que possam levar a qualquer tipo de identificação das travestis investigadas. Estas serão tratadas sempre pelos pronomes femininos, em virtude de ser este o uso corrente entre elas. 


\section{IDENTIDADE}

O entendimento das diferentes modalidades de transgêneros tem sido marcado por posições bastante divergentes, principalmente entre aquelas advindas das Ciências Biológicas e as desenvolvidas nas Ciências Humanas ${ }^{1}$. Embora o presente estudo se utilize de conceitos próprios às últimas, como o de identidade, tema deste capítulo, é importante que algumas considerações críticas sejam feitas a respeito da forma como as diferentes modalidades de transgêneros são muitas vezes compreendidas no campo das Ciências Biológicas, em especial na Psiquiatria. Isso se deve ao fato de tais concepções serem hegemônicas em diversos contextos sociais, determinando políticas públicas de saúde e, em alguns casos, delimitando a própria configuração de algumas identidades transgenéricas, como veremos adiante.

\section{Travestismo e Transexualismo na Psiquiatria e Psicologia}

Os termos travestismo e transexualismo ${ }^{2}$ foram historicamente reservados na literatura médica e psicológica a indivíduos que buscavam de alguma forma atributos considerados como típicos do sexo oposto ao próprio. Tais termos, contudo, não incluem os fenômenos relacionados à chamada intersexualidade ou hermafroditismo, que corresponde aos diversos tipos de síndromes cromossômicas, de disfunções hormonais e de má formação fetal que geram alterações nos órgãos genitais primários ou secundários. Embora alguns teóricos postulem a existência de alterações

\footnotetext{
${ }^{1}$ Ver, a esse respeito, os artigos do International Journal of Transgenderism, periódico onde ambas as posições estão presentes, mas em artigos distintos.

${ }^{2}$ Para evitar leituras equivocadas, utilizaremos os termo em itálico quando estivermos nos referindo a categorias psiquiátricas (por exemplo, o transexual, como alguém portador de um distúrbio) e sem destaque quando nos referirmos a uma compreensão identitária (por exemplo, o transexual como alguém que participa de movimentos associativos).
} 
cromossômicas e hormonais nos casos de travestismo e transexualismo, tal posição é minoritária entre os estudiosos do tema.

As definições nos manuais médicos e psiquiátricos contemporâneos dos quadros referidos diferem pouco uma das outras. Utilizamos aqui as definições que constam da Décima Revisão da Classificação Internacional de Doenças e de Problemas Relacionados à Saúde (CID 10), produzida pela Organização Mundial da Saúde (OMS). Tais definições são bastante próximas às do Manual de Diagnóstico e Estatística de Doenças Mentais, produzido pela American Psychiatric Association, em sua quarta edição (DSM IV) $)^{3}$.

\section{Seguem as definições de tais termos:}

Transtorno de identidade sexual na infância (CID: F64.2)

Transtorno que usualmente primeiro se manifesta no início da infância (e sempre bem antes da puberdade), caracterizado por um persistente e intenso sofrimento com relação a pertencer a um dado sexo, junto com o desejo de ser (ou a insistência de que se é) do outro sexo. Há uma preocupação persistente com a roupa e as atividades do sexo oposto e repúdio do próprio sexo. O diagnóstico requer uma profunda perturbação de identidade sexual normal; não é suficiente que uma menina seja levada ou traquinas ou que o menino tenha uma atitude efeminada.

\section{Transexualismo (CID: F64.0)}

Trata-se de um desejo de viver e ser aceito enquanto pessoa do sexo oposto. Este desejo se acompanha em geral de um sentimento de mal estar ou de inadaptação por referência a seu próprio sexo anatômico e do desejo de submeter-se a uma intervenção cirúrgica ou a um tratamento hormonal a fim de tornar seu corpo tão conforme quanto possível ao sexo desejado.

\section{Travestismo bivalente (CID: F64.1)}

Este termo designa o fato de usar vestimentas do sexo oposto durante uma parte de sua existência, de modo a satisfazer a experiência temporária de pertencer ao sexo oposto, mas sem desejo de alteração sexual mais permanente ou de uma transformação cirúrgica; a mudança de vestimenta não se acompanha de excitação sexual.

\footnotetext{
${ }^{3}$ No caso do DSM, o transexualismo foi catalogado como um novo distúrbio em sua edição de 1980, conforme mostra Stone (1991)
} 
Travestismo fetichista (CID: F65.1)

Vestir roupas do sexo oposto, principalmente com o objetivo de obter excitação sexual e de criar a aparência de pessoa do sexo oposto. O travestismo fetichista se distingue do travestismo transexual pela sua associação clara com uma excitação sexual e pela necessidade de se remover as roupas uma vez que o orgasmo ocorra e haja declínio da excitação sexual. Pode ocorrer como fase preliminar no desenvolvimento do transexualismo.

In OMS / FSP / OPAS, 1993.

Há alguns dados que podemos perceber nas definições consideradas. $O$ principal deles é que a presença desses quadros em tais Manuais os configuram enquanto doenças - lembrando aqui que o homossexualismo deixou apenas na década de 70 de ser considerado como uma. Um outro ponto importante é o de que um quadro único na infância, o transtorno de identidade sexual, passa a ser claramente dividido em dois mais gerais na vida adulta, ou seja, o transexualismo e o travestismo, que por sua vez se divide em outros dois. Finalmente é importante observar que tais definições sustentam-se em um critério tríplice: de haver ou não o desejo de pertencimento ao sexo oposto, algo de uma esfera subjetiva, da presença ou ausência da busca de uma transformação corpórea na direção do sexo oposto e da existência (ou não) do hábito de se vestir conforme alguém do sexo oposto, sendo cada um dos quadros uma combinação distinta entre estes três critérios.

Frente ao que foi exposto, há uma série de elementos que merecem ser objeto de avaliação crítica. O primeiro deles refere-se à ausência em tais conceitos do entendimento da sexualidade como socialmente construída. Embora as explicações a respeito da origem do travestismo e do transexualismo não estejam presentes nestas definições, elas fazem pensar em um determinismo psíquico, na medida em que o desejo aparece como um elemento primordial na definição de tais quadros. Mas o desejo parece ser entendido aqui em uma dimensão a-histórica, na medida em que não há referência ao seu processo de construção social, nem mesmo contextualização cultural. Tal posição, de "explicar as propriedades de um todo complexo por referência a uma suposta verdade ou essência interior" é o que caracteriza a visão essencialista da sexualidade, segundo Weeks (2000, p. 43). 
Um segundo ponto importante refere-se ao fato de que a atribuição de um status de doença a tais quadros confere aos mesmos um lugar de anormalidade. Para Rubin (1999) a consideração da anormalidade de um indivíduo a partir de sua prática sexual é um fenômeno bastante presente nas sociedades ocidentais contemporâneas e está diretamente relacionada ao estabelecimento de uma hierarquia de aceitabilidade entre as práticas sexuais, onde algumas passam a ser consideradas "superiores" e outras "inferiores". Segundo a mesma autora, tal atribuição legitima o discurso moralista a respeito da sexualidade, que historicamente se faz presente em uma série de perseguições aos desviantes. Weeks (2000) complementa esta idéia, mostrando que a definição de anormalidade serve também, nos discursos médicos, políticos e judiciários, para delimitar de forma precisa o conceito correlato, ou seja, o de normalidade. Nos casos do transexualismo e travestismo, está implícita a idéia de que os indivíduos devam desejar fazer parte de seu próprio sexo.

As definições de tais quadros promovem também uma visão uniforme das condutas: passam a existir o transexual e o travestido como tipos de indivíduos que são diferentes dos demais (os "normais"), o que configura uma terceira crítica possível a ser feita. Tal atribuição de uma realidade visível e permanente às perversões, que se dá pelo mecanismo da especificação dos indivíduos, é descrita por Foucault (1976). Citando como exemplo a sodomia, Foucault mostra como um tipo de ato proibido anteriormente vai transformar seu praticante, a partir do século XIX, em um personagem específico, um tipo diferente de ser humano, ou seja, o homossexual. ${ }^{4}$. Em seu estudo sobre cross-dressers londrinos(as), Woodhouse (1989) faz a crítica à universalização das condutas, observando que não há um "transvestite type", algo que os distinga dos homens "normais", em termos de personalidade, fatores psicológicos ou história de vida em comum (p. 56 e 73).

Um outro aspecto importante nestas definições é o da tentativa de se conter a diversidade sexual em um número limitado de formas. Os seres humanos são classificados segundo uma lógica binária em termos da tríade desejo, corpo e forma de se vestir, conforme foi observado anteriormente, o que nos dá um número limitado de

\footnotetext{
4. Foucault (2001) cita um processo análogo ocorrendo também com a figura do masturbador (p. 78)
} 
combinações. A tentativa de limitação da diversidade e pluralidade sexuais é criticada por Rubin (1999), que propõe que se lute por uma moralidade democrática onde haja o reconhecimento do direito a essa pluralidade.

Um outro ponto ainda, referente às definições psiquiátricas de transexualismo e travestismo, refere-se à idéia subjacente na descrição destes "distúrbios" de haver uma identidade interior a tais indivíduos, na medida em que passam a ser definidos - e provavelmente a se definir - segundo o desejo e a forma de se comportar. Tal idéia remete a uma concepção de identidade como parte essencial da personalidade, concepção esta criticada por Weeks (2000), por des-historicizar o conceito de identidade, algo que para ele é objeto de uma lenta construção coletiva, seja ela imposta e/ou escolhida

As críticas aos conceitos médico-psiquiátricos de transexualismo e travestismo dizem respeito, em última instância, à própria forma como se constituiu o saber acerca da sexualidade. Referência fundamental de algumas concepções surgidas nas Ciências Humanas, geralmente agrupadas sob o termo "construcionismo", Foucault (1976) mostra que o próprio termo "sexualidade" já se refere a um campo discursivo específico sobre o sexo, nascido sob os auspícios da Medicina e outras Ciências, a partir da técnica de confissão. Pensar tais conceitos dentro de um referencial construcionista, portanto, implica necessariamente em uma desconstrução dos mesmos. Para tanto são necessárias diversas rupturas:

- com o referencial médico e psiquiátrico que está na origem de tais termos, que leva a entendê-los como algo da ordem da interioridade dos seres humanos, configurando um essencialismo biologizante e/ou psicologizante. Grande parte do debate médico a respeito do transexualismo, por exemplo, remete-se a um embate esses dois "tipos" de determinismo: de um lado, os que defendem a solução cirúrgica para "correção do distúrbio", o que implica pensar que o corpo deve se adaptar ao psiquismo; de outro, posição cada vez mais minoritária, os que defendem os métodos psicoterápicos, na expectativa que o psiquismo possa se conformar ao corpo. A esse respeito, ver, por exemplo, as obras dos brasileiros Farina (1982) e Vieira (1996). Embora rivais, ambas 
as correntes buscam uma "verdade interior" ao indivíduo, no corpo ou no psiquismo, deixando em segundo plano as análises sócio-históricas de tais fenômenos.

- com o conceito de normalidade que é inerente a sua definição como doença ou distúrbio, conceito este que também deve ser entendido como uma construção histórica. Foucault (1975) situa a idéia de normalidade como uma decorrência do poder disciplinar, que surge no Ocidente a partir do final do século XVII, a partir da necessidade de transformação e aperfeiçoamento do corpo em algo dócil e útil e que vai estabelecer toda uma série de controle sobre tal corpo, buscando a homogeneização dos indivíduos e coibindo seus desvios. Daí necessidade de definição do que é "normal" ou não. No campo construcionista, alguns autores tem chamado a atenção para a necessidade de se estudar não somente a constituição histórica do que é considerado anormal, como também do que é tido como normal, como forma de desconstruir tais noções. A esse respeito, Katz (1996) observa:

\footnotetext{
Falamos sobre travestismo (dando-lhe este nome) problemático, o desejo de vestir roupas do sexo oposto. Geralmente não falamos sobre o forte desejo de vestir roupas do nosso próprio sexo (ou damos a isso um nome). Mas por que a maioria de nós se sentiria profundamente mal vestindo publicamente roupas do sexo oposto ? O nosso forte desejo de vestir roupas do próprio sexo não sugere um mistério a ser explicado? Falamos sobre transexualismo (dando este nome) problemático, a sensação de ser do sexo oposto, o desejo de ter o corpo do outro sexo. Não falamos muito sobre a sensação de ser do próprio sexo (ou damos a isso um nome) - o sexo que acreditamos ser o nosso, o que a maioria de nós deseja conservar. Mas o fato de nos sentirmos relativamente bem com o nosso sexo e o forte desejo de manter a nossa integridade sexual não indicam algo que precisa ser explicado, tanto quanto o transexualismo ? (p. 26)
}

- com a uniformização das condutas que é subjacente a tais conceitos, aceitando-se em contrapartida uma idéia radical de diversidade, da possibilidade humana quase infinita de construir novas formas de subjetividade. Gordo-Lopez (1996) ao observar clínicas de realinhamento sexual em Londres, mostra como indivíduos muito diversos entre si se tornam parecidos, em termos do comportamento e opiniões, após todo trabalho psicoterápico e de esclarecimento prestados pelos profissionais dessas clínicas. Para Shapiro (1991) os(as) transexuais sofrem enorme pressão para produzir histórias de 
vida com o intuito de conseguir o que querem do establishment médico-psiquiátrico, reprimindo informações que criam problemas para as narrativas canônicas da identidade (p. 251). De forma semelhante, Stone (1991) observa que a variedade de experiências transexuais era deixada de lado em prol da dominante, cirúrgica, por transexuais que se orientavam pelo mesmo livro de referência utilizado pelo staff clínico (p.291-2). Isso nos leva a pensar que a própria visão médica delimita a subjetividade de tais indivíduos. O transexualismo, desta forma, pode ser entendido não como um distúrbio, mas como um possibilidade identitária, ainda que regulada pelo poder médico-jurídico, nos moldes definidos por Weeks (2000).

- com o entendimento que a divisão binária de gêneros é algo dado, natural. O entendimento do transexualismo e do travestismo dentro de uma perspectiva construcionista deve levar em conta o fato destas condições estarem em íntima relação com a organização do sistema de gêneros masculino/feminino. Lewins (1995) considera, inclusive, que o transexualismo é um fenômeno que contribui para a manutenção de uma divisão binária de gêneros, uma vez que, à medida que o indivíduo escolhe pertencer ao outro gênero e não a uma posição intermediária, acaba por reforçar tal divisão.

Se refletirmos sobre as travestis de baixa renda que se prostituem nas ruas de São Paulo, a inadequação das categorias médico-psiquiátricas fica ainda mais evidente. Qual seria, por exemplo, o limite entre o uso de uma vestimenta feminina e a busca de um corpo feminino, que é um dos principais critérios da diferenciação entre o travestismo e o transexualismo? Quais elementos deveriam ser considerados como diferenciais: o corte de cabelo, o uso de depilação, o uso de hormônios, a aplicação de silicone ou ainda algum outro ? Em relação ao modo de se vestir, as travestis pesquisadas, aliás, se permitiam o uso de roupas tipicamente masculinas sem se sentirem ameaçadas em relação a feminilidade por elas alcançada, algo que foi observado também por Hélio Silva (1993). Como definir em termos essencialistas tal fenômeno? Como o ato de um transexual (que se modifica na direção de um corpo feminino) que se traveste na direção oposta (em direção ao seu sexo de origem)? Sem 
dúvida tais definições parecem impróprias para se refletir sobre a experiência das travestis.

\section{O conceito de Identidade}

Uma alternativa possível levando-se em consideração as críticas feitas, é a de encarar as diversas modalidade de transgêneros (entre elas a das travestis) como identidades socialmente construídas. Tal perspectiva é comum nas Ciências Humanas, o que não significa afirmar que as diferentes concepções de identidade presentes sejam sempre compatíveis entre si. Para apresentar a proposta deste estudo, portanto, se faz necessária a discriminação entre algumas destas concepções e as implicações das mesmas, principalmente em virtude da utilização frequente desta categoria como instrumento de ação política, pela via das chamadas "políticas de identidade".

Uma vez que o conceito de identidade implica na consideração da relação entre indivíduo e sociedade, fica claro que o entendimento de tal conceito resulta da forma como tal relação é entendida em diferentes teorias. Consideramos aqui que tais concepções podem ser classificadas em três modalidades: aquelas que privilegiam o estudo da dimensão subjetiva da identidade, mais comuns na Psicologia Clínica, as que se concentram no estudo dos processos grupais, com enfoque microssocial, frequentes na Psicologia Social, e, finalmente, as que privilegiam uma dimensão social mais ampliada, onde se insere, por exemplo, a discussão acerca dos mecanismos geradores da proliferação das identidades nas sociedades contemporâneas, mais comuns nas Ciências Sociais.

A concepção da identidade como um atributo individual, no campo da Psicologia Clínica, tem forte influência das idéias de Erik Erikson (1968), para quem a identidade tem como um de seus atributos centrais a presença de um sentimento consciente da singularidade individual $(p, 187)^{5}$. Tal conceito em sua obra se sobrepõe em certa medida ao de ego, na medida em que a obtenção de um ego estruturado pressupõe o

\footnotetext{
${ }_{5}^{5}$ Discuto o conceito de identidade em Erikson mais extensamente em estudo anterior (Garcia, 2004)
} 
desenvolvimento de um "firme sentido de identidade" (p. 89). Erikson sofreu críticas não só pela excessiva individualização a que foi submetido o conceito de identidade ${ }^{6}$, como pela própria concepção de ego subjacente a sua teoria. Considerado um dos expoentes da denominada "Psicanálise do Ego", que se desenvolveu principalmente nos Estados Unidos, reproduz em sua obra a idéia central de que caberia ao processo psicanalítico o desenvolvimento de um "ego saudável", o que acabou sendo objeto de crítica de outras importantes escolas de psicanálise, como a kleiniana e a lacaniana. Em um estudo clássico, Lacan (1949) mostrou que a imagem de um eu unificado não se desenvolve naturalmente a partir da criança, mas sim a partir do olhar dos outros, o que dá a ela a noção de que é uma pessoa inteira. O ego, deste modo, corresponde a uma fantasia de si mesmo como pessoa unificada, o que sugere que a identidade deva ser entendida como algo necessariamente fragmentado, concepção esta bastante diversa da de Erikson.

Como alternativa a este entendimento monolítico da identidade no campo psicanalítico, alguns autores ${ }^{7}$ tem retomado o conceito freudiano de identificação, pelo fato deste permitir uma construção teórica compatível com a visão contemporânea que concebe os sujeitos como irremediavelmente cindidos entre diferentes identidades. Para Freud (1998), na obra de 1921, Psicologia de Grupo e Análise do Ego”, há, desde a infância, uma série de identificações com todas as figuras significativas para a criança, o que possibilita a existência de uma "pluralidade de pessoas psíquicas" em um mesmo indivíduo.

Nos desenvolvimento teóricos na Psicologia Social, por sua vez, o conceito de identidade que teve mais influência foi o proposto por Henri Tajfel, na que passou a ser denominada Social Identity Theory. Tajfel (1983) define a identidade social como a "parcela do autoconceito de um indivíduo que deriva do seu conhecimento da sua pertença a um grupo (ou grupos) social, juntamente com o significado emocional e de valor associado àquela pertença" (p 290). A partir desta definição, Tajfel e alguns seguidores, o principal dos quais foi Turner (1984), buscaram entender como se daria o

\footnotetext{
${ }^{6}$ Ver, a esse respeito, Slugovski \& Ginsburg (1990, p. 37-39)

7 Ver, a esse respeito, Manonni (1992)
} 
processo da formação da identidade nos grupos sociais, propondo uma concepção universalista do fenômeno, baseada em evidências experimentais. Nestas experiências, os sujeitos mostravam uma tendência a acentuar as diferenças entre os grupos e as similaridades dentro de cada um dos grupos, buscando distinguir positivamente o próprio grupo em detrimento dos demais, o que levou Tajfel (1983) a propor que a identidade social seria sempre "positiva" uma vez que era calcada no favorecimento relativo do próprio grupo de pertença ${ }^{8}$. As críticas direcionadas à Social Identity Theory foram baseadas principalmente no fato de que suas premissas desprezavam uma necessária análise "macrossocial" das condições dos grupos estudados, o que implicava em localizar o processo de formação da identidade positiva descrito como algo específico de países capitalistas centrais e como algo não aplicável a grupos submetidos a um processo histórico de dominação ${ }^{9}$.

Apesar das críticas de cunho sociológico aos desenvolvimentos teóricos da identidade no campo da Psicologia Social, cabe ressaltar que tal conceito permanece tema de inúmeras pesquisas na área, como mostram algumas revisões dedicadas ao tema $^{10}$. Nestas, parece haver uma progressiva aproximação com as concepções sociológicas de identidade, sem abandonar, contudo, a dimensão grupal como objeto central de análise. Por serem construídas como posições dentro do campo simbólico de uma cultura, como mostra Duveen (2001), as identidades são sempre, em alguma medida, construídas externamente ao indivíduo ou seu grupo, ao mesmo tempo que organizam os significados aos sujeitos, provendo-os com um sentido de estabilidade. Assume-se que o tema da identidade é necessariamente complexo, uma vez que cada um de nós incorporamos diferentes identidades, ativadas em determinadas ocasiões (Cassidy e Trew, 1998), e que estudos voltados a uma só modalidade de identidade como de raça ou de gênero - acabam por excluir populações particulares que porventura se organizem identitariamente de maneiras diversas (Frable, 1997, p 155).

\footnotetext{
${ }^{8}$ Caso isto não ocorresse, o indivíduo tenderia a mudar de grupo, ou, se isto fosse impossível, buscaria reinterpretar as características do próprio grupo na busca de uma positividade e/ou se engajaria em tentativas de mudança das características concretas do grupo ao qual pertencesse (Tajfel, 1983, p 291)

${ }_{9}$ Ver, a esse respeito, Amâncio (1999, p. 298-9)

${ }^{10}$ Ver Frable (1997) e Ellemers, Spears \& Doosje (2002). Em relação às pesquisas brasileiras, ver Paiva (2004).
} 
Nas contribuições de cientistas sociais ao estudo da identidade, a utilização do termo por si só é objeto de polêmica. Ao reconhecer o fato das identidades serem produto da história da sociedade e cultura em que vivemos, alguns autores importantes vão acentuar o caráter normativo das mesmas. Guattari (1986) considera que as identidades correspondem à forma de subjetividade típica do Capitalismo contemporâneo, que impede a singularidade, a qual, por sua vez, se manifestaria sob o signo da pluralidade e multiplicidade. Há, desta forma, uma negação da diversidade quando se afirma uma dada identidade. De uma forma menos incisiva, Foucault (1982b) também situa os riscos de constrangimento dos movimentos criativos quando ocorre uma fixação das identidades. Para estes e outros autores, a criação de uma identidade leva necessariamente a uma uniformização das condutas e, se o sentimento de inadequação que leva a sua busca poderia suscitar inúmeras formas de subjetividade como resposta, estas serão controladas e legitimadas pelos grupos sociais que sustentam a nova identidade, impedindo uma efetiva subversão.

Um outro aspecto relevante, referente aos movimentos de afirmação identitária, diz respeito ao fato de muitas vezes estas levarem a uma sujeição a formas de dominação sofisticadas e, por isso, invisíveis aos sujeitos que afirmam tais identidades. Em sua discussão a respeito da identidade "mulheres", por exemplo, Butler (1993) considera que sua utilização implica no encobrimento do fato de que o termo "mulher" só faz sentido quando pensado em um contexto heterossexual oposicional, o que significa privilegiar normativamente as relações heterossexuais como a base de uma política feminista.

Como resposta a estas implicações relacionadas ao próprio conceito de identidade alguns autores tem tentado resgatá-lo, aceitando, contudo, suas contradições. Para Hall (2000), tal conceito pertence a uma classe daqueles que 
É necessário, neste sentido, o reconhecimento de que as identidades implicam em posições de sujeito a serem por nós ocupadas e de que trazem de forma intrínseca a elas aspectos coercitivos. Mas é possível se pensar, também, que podem trazer consigo um espaço para uma constante alteração desta mesma identidade. Para isso, é necessário um movimento permanente de crítica às reivindicações essencialistas que são feitas por inúmeras afirmações identitárias, nas quais passa a ser vista como algo fixo e imutável (Woodward, 2000, p 13) e uma ênfase na percepção de que as identidades são construídas discursivamente e, portanto, em locais históricos e institucionais específicos (Hall, 2000, p 111). Implica na necessária análise das dimensões de seu desenvolvimento, manutenção e mudança, um desafio proposto por Frable (1997) para os estudos que utilizam a identidade como categoria central, e ao qual buscamos responder de forma adequada em nosso estudo.

A identidade é aqui, portanto, compreendida a partir desta ambiguidade que lhe é inerente, uma vez que implica necessariamente, por um lado, em uma sujeição a lugares engendrados por estruturas sociais históricas particulares (Berger e Luckman, 1966, p. 229) e, por outro, na possibilidade implícita de transformação destes mesmos lugares e de criação de novos, o que sugere uma possibilidade de se contrapor às diversas formas de dominação existentes. Trata-se de se discutir, em cada caso particular, em que medida uma dada identidade corresponde a uma confirmação do poder e em que medida corresponde a uma resistência ao mesmo, se nos utilizarmos dos termos foucaultianos. A decorrência desta compreensão para as chamadas "políticas de identidade", utilizadas por alguns movimentos sociais como forma de luta por reconhecimento e por direitos, manifesta-se sob a forma de um apoio crítico: reconhece-se ao mesmo tempo a necessidade de afirmação das identidades bem como a de crítica e desestabilização das mesmas. Para Butler (1993) os discursos que mobilizam categorias identitárias são politicamente importantes, mas ao mesmo tempo cultivam identificações unitárias, o que leva à necessidade de um movimento de desidentificação no interior destes movimentos, caso se deseje promover uma contestação democrática de fato (p.4) $)^{11}$.

\footnotetext{
${ }_{11}$ Discussão semelhante, em relação ao movimento homossexual, é feita por Gamson (1998)
} 


\section{Identidade entre transgêneros}

Um aspecto relevante em qualquer discussão que diga respeito ao conceito de identidade refere-se ao fato de que estamos em um período histórico onde muitas delas estão sendo fracionadas. O impacto das novas tecnologias surgidas, principalmente após a Segunda Guerra Mundial, gerou mudanças importantes no campo da subjetividade. O mundo da modernidade, construído sob a égide do lluminismo, tinha como característica marcante o fato de ser administrável, controlável e previsível e como contrapartida o sujeito racional, pleno, unificado e soberano, como mostra Figueiredo (1995). Mas tal sujeito é des-substancializado na pós-modernidade ${ }^{12}$. Há uma pulverização de modelos identificatórios neste período, o que faz com que o indivíduo tenha o sentido de identidade abalado. Com a perda das referências universais, o indivíduo fica invadido pela multiplicidade de signos e atomizado pelos meios de comunicação de massa. Enquanto o sujeito da modernidade buscava as transformações sociais, o indivíduo pós-moderno se concentra em si mesmo, privatizando cada vez mais sua vida ou, quando luta por algo, esse algo é sempre parcial e fragmentário.

O período atual corresponde, assim, de acordo com Hall (2003), a um período histórico de fragmentação das identidades de gênero, sexualidade, etnia, raça e nacionalidade, justamente aquelas que mais eram definidoras da estabilidade social. Esta desarticulação das identidades passadas ao mesmo tempo, porém, contribui para a criação de novas, as quais, contudo, são muitas vezes contraditórias, parciais, móveis, e não são, na maior parte das vezes, assumidas pelos indivíduos em sua totalidade. Para Hall (2003), o sujeito pós-moderno não tem identidade fixa e convive com identidades incoerentes entre si a partir da construção da narrativa (ilusória) de um "eu", que tenta assimilar tais contradições.

O surgimento das diversas modalidades de transgêneros na contemporaneidade, sob a forma de novas identidades "transgenéricas", como no caso das travestis, pode

\footnotetext{
12 Utilizo o termo pós-modernidade aqui por ser um termo já consagrado, embora esteja ciente das objeções feitas ao mesmo.
} 
ser pensado como uma consequência do processo anteriormente exposto. Esse entendimento, porém, não é isento de críticas. Uma delas refere-se à possibilidade de tal processo de dissolução das identidades "tradicionais" ser específico de sociedades capitalistas tecnologicamente avançadas e que, portanto, tal compreensão não poderia ser meramente transposta para países capitalistas periféricos. Embora reconheça a pertinência dessa crítica, penso que é possível considerar também que o contexto social em que se dá o surgimento das novas identidades transgenéricas no Brasil, entre elas a travesti, tem características em comum com o contexto descrito por Hall (2003) Entre estas, a serem melhor exploradas no decorrer deste estudo, está a apropriação de novas tecnologias - no presente caso, de transformação corpórea. $O$ fato das travestis passarem a existir enquanto grupo social primariamente metropolitano faz pensar também na necessidade prévia de rompimento nesse segmento com as identidades brasileiras "tradicionais"13.

Historicamente o termo transgênero surgiu como uma espécie de "guarda-chuva" para englobar diversos grupos sociais onde a ambigüidade de gêneros tem um lugar marcante, como transexuais, travestis, cross-dressers, transformistas e drag-queens (drag-kings). Não há, contudo, uma definição clara para delimitar o significado do termo. Tal definição seria mais simples se considerássemos haver a existência de somente uma masculinidade e de uma feminilidade possíveis. Neste caso, o(a) transgênero seria alguém que rompe com o gênero socialmente esperado, se identificando com o oposto. Porém, supor uma oposição masculino/feminino como universal leva ao ocultamento do fato de que cada uma destas categorias é heterogênea, como mostra Scott (1994, p 21), e à negação do fato de que o que chamamos masculino e feminino tem uma história que os determina (Connell, 1997, p 34). A idéia da existência de múltiplas masculinidades e feminilidades - ou de múltiplas identidades masculinas e femininas torna o conceito de "transgênero" mais problemático, uma vez que é possível que em algumas masculinidades e feminilidades periféricas ocorra um rompimento com o que é considerado tipicamente masculino ou feminino, sem que haja a reivindicação por um

\footnotetext{
${ }_{13}$ Para Parker (2002) a própria construção da homossexualidade no Brasil só se tornou possível pelo processo de urbanização acentuado, o que fez com que ruas, parques e outros lugares públicos se tornassem palco para contatos homoeróticos muitas vezes impessoais, algo impensável, para ele, em um cenário social de menor escala (p. 89).
} 
gênero oposto ou por uma posição intermediária entre ambos. Como exemplo, podemos citar o caso das prostitutas de São Paulo, no final do século XIX e início do XX, analisadas por Rago (1991). Ao ocuparem o espaço público, domínio por excelência masculino, rompem com a concepção hegemônica de feminilidade, associada ao lar e à maternidade. Elas seriam, dessa forma, em alguma medida "transgêneros", se seguíssemos a idéia do masculino e do feminino como gêneros monolíticos. Obviamente mais apropriado, porém, seria a referência a este fenômeno como o desenvolvimento de uma outra identidade, ainda no campo da feminilidade, o que implica no entendimento do sistema de gêneros ocidental como binário, mas como algo que agrega ao mesmo tempo a diversidade em cada uma de suas polaridades. Argumento semelhante cabe no caso do homossexualismo masculino, no que diz respeito à formação de identidades onde há a incorporação de elementos tidos como tipicamente femininos, como no caso do "viado" e do "bicha", a serem analisados mais adiante.

Seguindo-se esta idéia de masculinidades e feminilidades plurais, porém, chegamos a outro impasse: transexuais que mudam cirurgicamente seu sexo para o feminino passariam a adotar uma das várias possibilidades de feminilidade existentes ou criariam uma nova identidade dentro do campo da masculinidade? A esse respeito, é interessante resgatar o comentário de uma travesti em um encontro do Grupo, direcionado a outra participante, operada:

\footnotetext{
"Você pode operar, fazer uma buceta, que você vai continuar a ser uma bicha como nós”.
}

Neste caso, não importaria a remoção do pênis e a construção cirúrgica de uma vagina, uma vez que a transexual em questão continuaria a ter uma identidade dentro das masculinas possíveis ("bicha"). É nesse sentido que o termo "transgênero" permanece útil, pois, embora de difícil definição, sugere tipos de experiências e subjetividades onde se insere a ambigüidade de gêneros, na medida em que os(as) transgêneros criam identidades sociais não facilmente classificáveis como masculinas ou femininas. 
A existência de diferentes modalidades de transgêneros, embora unidas pala ambiguidade de gêneros, faz pensar em identidades demarcadas umas das outras. Quando falamos em identidades sociais há sempre esse duplo aspecto: se por um lado o surgimento de uma nova possibilita a realização de potencialidades humanas que ainda não tinham sido expressas, por outro tal identidade vai constranger as possíveis subjetividades que lhe são contíguas em uma certa direção. Nesse sentido, é interessante notar o esforço comum em diversos tipos de transgêneros de diferenciar sua experiência de formas contíguas: travestis de transexuais, transformistas de crossdressers e assim por diante. Ao mesmo tempo, qualquer trabalho de campo aprofundado leva à constatação de que as diferenças entre os membros de um mesmo grupo são bem mais acentuadas do que a identidade "oficial" faz supor ${ }^{14}$. Tal observação é feita em estudos sobre algumas modalidades de transgêneros. Newton (1979) observa que os(as) transformistas que estuda procuram se diferenciar de crossdressers pelo fato de não sentirem prazer sexual em usar roupas femininas, mas ao mesmo tempo observa que vários(as) deles(as) apontam ser comum tal prazer entre transformistas, principalmente no início de carreira. Da mesma forma, Woodhouse (1989) observa que os(as) cross-dressers por ela estudados procuram se diferenciar dos(as) transexuais pelo fato de não buscarem mudança definitiva de sexo, embora relate casos de cross-dressers que procuram por cirurgias de transgenitalização após algum tempo.

Finalmente, cabe ressaltar que, embora existam configurações regionais definidoras das possíveis identidades "transgenéricas", há uma grande semelhança de algumas delas em sociedades ocidentais diversas. As características dos(as) crossdressers londrinos(as) descritas por Woodhouse (1989) se assemelham às dos(as) mesmos(as) no Brasil ${ }^{15}$. Os(as) transformistas analisados(as) por Newton (1979) em Chicago se parecem aos(às) descritos(as) por Green (2000), em São Paulo e no Rio de Janeiro. Tal fato, longe de sugerir qualquer universalismo baseado na biologia, faz

\footnotetext{
14 Para Cassidy \&Strew ( 1998) a construção de um “protótipo” por parte de um grupo, frente ao qual os indivíduos do mesmo se avaliam em termos de sua adequação a ele, é um processo inerente à constituição identitária de qualquer grupo.

${ }^{15}$ Não tive acesso a nenhuma pesquisa específica sobre cross-dressers no Brasil. Tal impressão se deve a consulta a diversas páginas na Internet de cross-dressers brasileiros(as)
} 
pensar na existência de comunidades que rompem barreiras nacionais e se moldam a partir do contato com comunidades similares. Altman ${ }^{16}$ (apud Parker, 2002, p. 17) denomina tal processo, no interior do homoerotismo, de "homossexualização global" (global queering) e considera que o mesmo é resultado da crescente influência dos meios de comunicação de massa sobre as sociedades em todo o mundo. O advento da pandemia da AIDS, para Parker (2002), acelerou ainda mais este processo, na medida em que provocou um debate mundial sobre os fenômenos ligados ao homoerotismo ${ }^{17}$.

\section{Panorama histórico do surgimento das travestis}

Uma vez que as novas identidades se constituem em um processo de transformação histórica que as possibilita, é importante traçar aqui um breve panorama histórico do surgimento das travestis enquanto grupo social. Não foi localizado nenhum estudo específico sobre este tema, mas é possível levantar alguns elementos relevantes a partir da obra de alguns estudiosos do homoerotismo masculino no Brasil, principalmente na de Green (2000), que se atém ao século XX.

Green (2000) adota como eixo de análise a idéia de que há no decorrer da história uma série de formas pelas quais se estruturam papéis sociais no universo homoerótico das grandes cidades brasileiras, com uma grande predominância, porém, de papéis estruturados em torno da díade ativo/passivo, pelo menos até a década de $70^{18}$. Parte-se da idéia de que em uma relação homoerótica há (ou deveria haver) sempre um indivíduo "ativo", que em uma relação sexual penetra o parceiro, e o "passivo", que é penetrado, papéis estes que remetem diretamente a uma concepção de masculinidade e feminilidade, na qual se supõe que o indivíduo "ativo" também

\footnotetext{
${ }^{16}$ ALTMAN, Dennis. On global Queering. Australian Humanities Review, n. 2 , 1997.

${ }_{17} \mathrm{O}$ fato de haver constelações familiares mais fluidas entre homossexuais também ajuda a explicar esse fenômeno, uma vez que o afastamento de muitos homossexuais de suas famílias de origem e o fato de grande parte não ter filhos possibilita uma maior mobilidade geográfica.

18 A idéia de um homoerotismo estruturado em torno dos papéis complementares ativo e passivo é uma constante nas obras de cientistas sociais e historiadores no Brasil, a começar por Peter Fry (1982), sendo referendada por Parker (1992, 2002).
} 
esteja ligado ao pólo masculino e o "passivo" ao feminino. Tal suposição está relacionada à idéia de que o indivíduo "passivo" deva ter características de personalidade também femininas, enquanto não haveria diferenças substantivas entre os indivíduos ativos e os heterossexuais quanto ao temperamento ou caráter. Há, assim, um descolamento, nessa atribuição, da idéia da masculinidade como algo que se refere a homens e da feminilidade como algo referente a mulheres: em um universo basicamente composto por homens, ambos os gêneros estão todo o tempo presentes. Embora a representação do homossexual como ativo ou passivo atravesse os primeiros três quartos do século $X X$ de forma quase absoluta, há, para o mesmo autor, vários registros históricos que mostram que tal divisão não se deu de forma rígida, como mostram inúmeros relatos de fontes médicas, policiais, jurídicas e artísticas por ele citados, que apontam indivíduos efeminados exercendo sua sexualidade de forma "ativa" e vice-versa (p. 175).

Green (2000) observa que na virada do século XIX para o XX popularizou-se no Rio de Janeiro, então capital e maior cidade do Brasil, o termo "fresco" para designar homens com aparência e/ou comportamentos efeminados. O termo "fresco" era utilizado sobretudo de forma pejorativa em charges e piadas da época e tinha como contraponto a figura do "fanchono", que se referia a um homem com aparência e comportamentos tipicamente masculinos e que se relacionava sexualmente com homens efeminados (ou "frescos"). Ao mesmo tempo, o autor observa que havia uma constante associação dos "frescos" com a prática da prostituição na mídia, o que fica claro em outro termo constantemente utilizado para homens efeminados na época "puto". Embora a prática da prostituição masculina existisse, era bastante incipiente, o que sugere que essa associação era muito mais imaginária do que real ${ }^{19}$. Falta contudo, na obra do autor, uma explicação para o porquê da existência de uma representação do "fresco" como "puto" (ou seja, do homem efeminado como prostituto). Há, naquele momento histórico, uma clara associação dos "frescos" com as mulheres em termos de aparência e da preferência pelo comportamento sexual passivo, o que o autor ressalta em sua análise. Mas seria o comportamento amoroso dos mesmos um

\footnotetext{
19 São vários as passagens em que essa associação surge na obra de Green (2000) - ver, por exemplo, p. $63,69,81-2$ e 89.
} 
comportamento tipicamente "feminino"? Se cruzarmos a história do homoerotismo com a história das mulheres no Brasil, podemos perceber que não. Soihet (1997) e Abreu (1999) mostram que, no Rio de Janeiro do final do século XIX e início do XX, a prescrição de códigos de conduta para as mulheres era bastante rígida, em especial quanto à freqüência às ruas da cidade, que eram consideradas um domínio dos homens. As mulheres de segmentos populares que rompiam as restrições burguesas, na maior parte das vezes por necessidade, sofriam muitas vezes a acusação de prostituição. Para Rago (1991), que estuda o universo da prostituição em São Paulo no mesmo período, a associação da esfera pública (as ruas) com a prostituição funcionava de forma explícita como instrumento de contenção das mulheres no ambiente privado (a "casa"), impedindo-as de ocupar os espaços considerados masculinos. Da mesma forma, a sedução era tida como um atributo exclusivo de prostitutas. Podemos pensar, portanto, que embora os "frescos" fossem tidos como figuras feminizadas, os mesmos ocupavam um espaço eminentemente masculino, as ruas e parques, colocando em questão as próprias prescrições de gênero: um "fresco" era feminino na aparência e no comportamento sexual, mas masculino quanto ao espaço público que ocupava e às estratégias de sedução, flertando com possíveis parceiros de forma muito mais explícita do que seria possível às mulheres que seguiam as regras de decoro. As acusações e perseguições sofridas por eles deviam-se ao rompimento com a rígida separação das atribuições de gênero da sociedade de então, não diferindo das acusações que eram feitas às mulheres que representavam o mesmo rompimento. Talvez se houvesse uma conformação total às normas do feminino (como a ocupação do espaço tipicamente feminino, ou seja, a casa) os "frescos" sofreriam apenas a opressão direcionada às mulheres "normais" e não aquela ainda mais feroz destinada aos que rompem a barreira das normas de gênero, como fizeram as prostitutas ${ }^{20}$.

Na década de 20 surge o termo "viado" e na década de 30 o termo "bicha" como referência aos homens que preferiam ter relações sexuais passivamente (Green, 2000, p 144-7). A díade ativo/passivo se reproduz aqui com a figura complementar ao "bicha",

\footnotetext{
${ }^{20}$ Tal idéia é desenvolvida pelo próprio Green (2000, p 104) quando o mesmo fala da aceitação de determinados costureiros, cabeleireiros e transformistas em décadas mais recentes. A idéia de que determinados fenômenos questionam apenas superficialmente a binariedade de gêneros, mas acabam por confirmá-la em uma outra perspectiva é desenvolvida por diversos autores.
} 
que é o "macho" a princípio e o "bofe" a partir da década de 50 . A década de 50 vai corresponder ao início do surgimento de novas modalidades de relacionamento homoerótico nos grandes centros do Brasil. Aos poucos, o modelo ativo/passivo cede lugar a um outro, baseado na interação sexual entre homens onde tais posições são flexíveis. Surgem as figuras do "entendido" na década de 60 e finalmente a do "gay" na década de 70, como mostra Fry (1982)

O surgimento de uma nova identidade que rompe com o modelo de atividade e passividade é relacionada por Green (2000) e Parker (2002) ao incremento populacional das grandes cidades brasileiras e ao crescimento ainda maior das "comunidades gays" das mesmas, devido principalmente à migração de indivíduos com preferências sexuais por pessoas do mesmo sexo, fugindo do preconceito mais exacerbado das pequenas cidades. A partir da década de 70 , a difusão, por via da televisão, revistas e jornais, dos movimentos gays europeus e norte-americanos, além do maior intercâmbio e viagens internacionais, aceleram ainda mais este processo de criação de uma "identidade gay" no Brasil. Tal identidade vai surgir, assim, principalmente nos segmentos de renda médios e altos metropolitanos, por causa do maior peso que tais segmentos passam a ter na sociedade brasileira no período, como afirma Perlongher(1987a, p.62 e 84), mesmo segmento que tradicionalmente manteve contato e foi influenciado pelas culturas norte-americana e européia, de acordo com Parker (2002, p 66)

O modelo gay "igualitário" não fez desaparecer, contudo, o modelo tradicional ativo/passivo entre homens que se relacionam sexualmente com homens no Brasil. Diversos autores ${ }^{21}$ observam que, enquanto o modelo gay "globalizado" impera nos segmentos médios e altos, o "antigo" modelo continua a existir de forma predominante em camadas populares. Green (2000) considera que o modelo igualitário, por pressupor relações mais "assumidas", só é acessível em contextos onde os homens com preferências homoeróticas consigam uma relativa independência financeira em relação à família, algo para ele mais difícil de ser conquistado em áreas rurais e segmentos de baixa renda ( $p$ 458).

\footnotetext{
${ }^{21}$ Por exemplo, McRae (1983), Green (2000) e Parker (2002)
} 
No que diz respeito à prostituição masculina, o mesmo autor observa a existência de alguns homens efeminados vivendo como profissionais do sexo em São Paulo já na década de 30, conforme mostram registros médicos e policiais. Era de certa forma comum a prática de se dar uma gratificação financeira ao homossexual passivo, o que servia como fonte de renda para alguns $(p 124,131)^{22}$. Da mesma forma, alguns homossexuais efeminados trabalhavam em pensões e bordéis, o que facilitou seu contato com o universo da prostituição feminina, levando-os a se prostituir ocasionalmente nestes locais ( $p$ 131, 150 e 167), que passaram a reunir, portanto, dois grupos marginalizados, facilitando sua aproximação (p. 151 e 161). O mesmo autor, porém, considera que a prostituição se disseminou de forma ampla dentro do universo homoerótico somente a partir das décadas de 60, com o surgimento da figura do "michê", e de 70, com a figura da "travesti", mais uma vez representando a díade de gêneros, uma vez que corresponderiam, de acordo com Perlongher (1987a, p. 19) aos estereótipos do homem e da mulher. ${ }^{23}$

O termo "michê" era - e ainda é, em alguns locais do país - originalmente utilizado como sinônimo de uma relação sexual paga com uma prostituta, significando algo como o termo "programa" nos dias de hoje. Aos poucos, a figura do indivíduo que fazia "michês" foi se profissionalizando e crescendo em número, com o aumento das grandes cidades, passando o termo a designar uma figura específica dentro do universo homoerótico. Para Parker (2002) o michê é uma figura expressiva deste universo e é justamente pela negação de sua preferência sexual por homens que mantém sua identidade de "macho" e seu fascínio sobre os clientes, em busca desse estereótipo para um relacionamento sexual. A violência muitas vezes praticada pelos michês é pressuposta no sistema de gêneros brasileiro: o michê é violento porque é isto que se espera do "macho", o que é observado por alguns michês entrevistados por

\footnotetext{
${ }_{22}$ Também citado por informante de Ferreira (2003, p 41) no mesmo período, em Belém do Pará.

23 As figuras do travesti e do michê, se por um lado parecem representar fielmente a dicotomia ativo/passivo ou masculino/feminino, rompem com essa separação por outro, pois esses estereótipos não se reafirmam sempre no mundo concreto, uma vez que há freqüentemente uma inversão dos papéis sexuais no relacionamento desses profissionais do sexo com seus clientes, com as travestis penetrando e os michês sendo penetrados pelos mesmos. Tal processo nos domínios do sexo comercial, para Parker (2002), reflete justamente a emergência de um novo modelo homoerótico onde ambos os comportamentos sexuais são comumente realizados pelos mesmos indivíduos.
} 
Parker (2002 p 78-9), que referem que são muitas vezes solicitados por seus clientes a agir de forma agressiva.

O termo travesti, por outro lado, até a década de 60 era reservado a indivíduos que se vestiam como mulheres, seja em paródias carnavalescas, em shows ou mesmo no cotidiano, não havendo, ainda, a conotação de prostituição, como mostra Green (2000, p 384). Barbosa da Silva (2005), no estudo clássico realizado em 1958 na cidade de São Paulo e resgatado recentemente, define travesti como "indivíduo que usa roupas femininas para exibição da orientação valorativa do grupo homossexual", acrescentando que o termo é "também utilizado no sentido depreciativo por um homossexual dissimulado em relação a um ostensivo"(p 191).

$\mathrm{Na}$ década de 60 o termo passou a se referir principalmente às transformistas ${ }^{24}$ de shows que proliferaram pelo país (Green, 2000), as quais "associavam glamour, sedução feminina, corpos esculturais e rostos cuidadosamente maquiados", encarnando e às vezes exagerando "os estereótipos associados como o gênero que adotavam" ( $p$ 377-8). A aceitação das mesmas era condicionada à presença de marcas de gênero apropriadas ( $p$ 372). Segundo um informante de Perlongher (1987a, p 87), no começo dos anos 60 haviam poucas travestis em São Paulo, que se limitavam aos teatros e boates e passavam desapercebidas, e, embora houvesse contiguidade em relação às áreas ocupadas pela prostituição feminina, não havia mistura entre estes dois grupos.

A partir da década de 70 o termo travesti passou a ser utilizado para designar um grande número de indivíduos que passaram a ocupar determinados espaços nas grandes cidades para se prostituir, se utilizando não somente de roupas e adereços tidos como tipicamente femininos, como cabelos longos, unhas pintadas e depilação de algumas áreas do corpo, mas também modificando o próprio corpo, pela via hormonal ou uso de silicone, em busca de um corpo semelhante ao feminino. João Silvério Trevisan, outro historiador importante do homoerotismo no Brasil, relata de forma bastante viva esta "explosão" das travestis nas metrópoles brasileiras:

\footnotetext{
24 O termo "transformista” está sendo por mim utilizado para distinguir as travestis que vivem profissionalmente de shows daquelas que se prostituem. Tal distinção era comumente feita pelas travestis objeto de nosso estudo.
} 
“Em 1976, quando voltei do meu exílio voluntário de três anos entre Estados Unidos e México, muita coisa tinha mudado no Brasil. Mas o que mais me surpreendeu foi a presença maciça de travestis prostitutos nas ruas do centro de São Paulo. Não eram um ou dois, mas dezenas que se multiplicavam a cada semana. Como no período de ausência eu não acompanhara sua conquista de terreno, meu olhar os examinava, perplexo. Mesmo porque até então eu só vira transformistas em boates gays brasileiras (...) As pessoas que passavam pelo centro, vindas de todos os pontos de São Paulo, olhavam entre boquiabertas e fascinadas aquelas putas escandalosas, de voz grossa, traços geralmente mais duros e pés grandes, assediados por carros que paravam e acertavam o preço. Mas não era só em São Paulo. Tratava-se de um fenômeno recorrente nas grandes cidades brasileiras, como pude comprovar.” (Trevisan, 1997, p. 74-75)

Entre as causas que podem ser apontadas para a disseminação das travestis pelas grandes cidades brasileiras, a partir da década de 70, uma delas refere-se aos novos recursos existentes de transformação corpórea, que possibilitaram a busca por um corpo de aparência mais feminina. Embora tenha surgido comercialmente na década de 60 , foi na década seguinte que a pílula anticoncepcional se popularizou no Brasil, tornando fácil o acesso aos hormônios femininos. O uso do silicone injetável é pouco posterior, citado por algumas travestis como ocorrendo já no final da década de 70 e por outras no início da década seguinte ${ }^{25}$.

Um segundo fator relevante é o da crescente desigualdade de classes a partir da década de 70 , que levou muitos homossexuais de camadas populares a buscar a prostituição como alternativa de renda (Trevisan, 1997, p 75). Se este fenômeno é descrito entre os michês estudados na década de 80 por Perlongher (1987a), parece ter se intensificado ainda mais entre homossexuais efeminados, devido ao preconceito existente em relação a sua condição, que dificulta outras formas de inserção profissional (Green, 2000, p 403) ${ }^{26}$. A relação entre a estigmatização de transgêneros e

\footnotetext{
${ }^{25}$ As informações que tive das próprias travestis do Grupo e as que constam na bibliografia são bastante discrepantes a respeito de quem foram as primeiras "bombadeiras", mas convergem em relação ao momento histórico.

26 Um dos argumentos problematizados nos estudos sobre a prostituição refere-se à frequente atribuição a motivos financeiros pela entrada na prostituição. Para Welzer-Lang (1994) este é um discurso construído nas diversas modalidades de prostituição para justificar sua prática. Perlongher (1987a, p 205) refere-se a este argumento como um "enunciado coletivo do negócio” entre michês, o qual concebe a prostituição como a única possibilidade de fuga da miséria e delinquência, negando relativa margem de
} 
a entrada na prostituição parece seguir a lógica do que chamamos "círculo vicioso": quanto mais estigmatizados, menos carreiras profissionais são a eles(as) acessíveis, levando muitos deles a se prostituir, o que contribui para aumentar o estigma frente ao grupo, e assim por diante.

Soma-se a essas duas razões ainda uma terceira, também referente ao universo da prostituição, muito mais difícil de ser estudada e que será objeto de consideração mais adiante, que é a do aumento da demanda pela prostituição de transgêneros, o qual pode ser relacionado tanto à ascensão social das classes médias e ao crescimento da população homoerótica nas grandes cidades, como à busca específica pelo relacionamento sexual com pessoas que trazem a ambiguidade sexual como marca ${ }^{27}$.

\section{A identidade travesti}

Embora os estudos sobre travestis realizados no Brasil, citados anteriormente, não tenham a identidade como categoria central, alguns se aventuram em discutir tal questão. Entre estes fica claro não haver um consenso a respeito de como se definiria a identidade das travestis. Há autores que afirmam a própria ambiguidade de gêneros, em uma mistura masculino-feminino, como definidora de sua identidade, como Florentino $(1998)^{28}$ e Benedetti $(2000)^{29}$. Uma posição próxima é a de que esta

escolha quanto ao ingresso na mesma. Embora concorde que tal argumento deva ser analisado de forma cautelosa, considero que o estigma social voltado às travestis é sem dúvida um fator fortemente responsável por sua entrada no universo da prostituição, conforme veremos no capítulo específico sobre o tema.

${ }_{27}$ Outras razões são apresentadas por Green (2000), que associa a disseminação de travestis e michês à "crescente comercialização e mercantilização do sexo na sociedade brasileira" (p. 403) e por Perlongher (1987b), que analisa de forma interessante a "explosão" das travestis como uma forma de resistência das homossexualidades populares à tentativa de imposição de um "identidade homossexual" típica de segmentos médios e altos, feita por militantes que se consideravam os legítimos representantes dos homossexuais como um todo (p 75-6). A primeira delas, em minha opinião, necessitaria ser melhor fundamentada pelo autor, uma vez que historiadoras da prostituição feminina, como Rago (1991) e Engel (1988) mostram que, pelo menos desde meados do século XIX, houve intensa mercantilização do sexo na sociedade brasileira. Já a segunda desconsidera o fato de que a disseminação das travestis pelas ruas das grandes metrópoles é anterior ao surgimento do chamado "movimento gay" no Brasil, que começa a se organizar no final da década de 70.

28 "Uma das características essenciais desse fenômeno é a ambiguidade, a dupla condição" (pg 164) 
ambiguidade na verdade representaria um "não-lugar", uma "não-identidade", o que podemos perceber em Neusa Oliveira $(1994)^{30}$ e Silva (1993) ${ }^{31}$. Há quem afirme um "gênero travesti", como uma espécie de terceiro gênero, para além do masculino e do feminino, como Ferreira (2003) ${ }^{32}$. Kulick (1998) interpreta tal questão diferentemente, afirmando que a identidade das travestis na verdade é a de "bichas verdadeiras", ou seja, de que acreditam carregar em sua condição a "verdadeira homossexualidade" e pretendem assumi-la em toda sua plenitude ${ }^{33}$.

Refletindo sobre esta divergência, um dos pontos que merecem ser levados em consideração é o da primazia da utilização da categoria gênero para se referir à identidade travesti. Se as categorias corpo, prostituição e violência são também abordadas nesses trabalhos, elas são deixadas de lado quando se fala no que define

29 "É a incorporação do feminino que autoriza as travestis a personificarem a ambiguidade, a camaleonidade de suas relações. Ao mesmo tempo que produzem meticulosamente traços e formas femininas no corpo, estão construindo e recriando seus valores de gênero, tanto no que concerne ao feminino bem como ao masculino." (pg 130)" "Vivem a experiência do gênero como um jogo artificial e passível de recriação. Por isso criam um feminino particular, com valores ambíguos. Um feminino que se constrói e define em relação ao masculino. Um feminino que é por vezes masculino. Vivem, enfim, um gênero ambíguo, borrado, sem limites e separações rígidas” (pg 131)

30 “Os travestis preferem não se definirem nem se auto-classificarem. Preferem ser o fator desordem nas trocas simbólicas entre identidades sexuais. Desejam abarcar as várias imagens que o espelho lhes devolve e, principalmente, permanecer definitivamente nas zonas de transição, em estado permanente de liminaridade" (pg 115). "Na aventura de não se colocarem em nenhum lugar social visível, os travestis não querem ser mulher, apesar de muitos se sentirem uma delas, não querem ser homossexuais e, muito menos, homens. Querem ser a diferença”. (pg 115)

31 "Tateando o terreno em sentido exploratório, poder-se-ia falar de uma transcondição ? Não no sentido de que "elas" tudo possam ser, mas no sentido de que há em sua condição um princípio de mutação que, por incidir sobre aspectos, dimensões, características extremamente básicas e estruturantes, as torna virtualmente mutantes, mutáveis. Nesse sentido, a transcondição não implica um exercício redundante de tudo ser, mas na afirmação básica (pelo exemplo), de um mutação radical, que tudo se pode ser.” (pg 127)

32 “... há outras possibilidades de gênero que vão além da tradicional dicotomia masculino e feminino. Fala-se nesse sentido de um gênero travesti, construído de sentimentos, práticas, comportamentos, linguagem, sexualidade e símbolos ambíguos, situado num espaço descontínuo entre dois pontos extremos de um sistema bipolar." (p. 33.). "Enquanto o binômio macho/fêmea representou o único modelo de gênero aceitável pelos europeus, pesquisas etno-históricas têm apontado que nas sociedades tribais as orientações sóciosexuais dos indivíduos ocorrem em contextos mais diversificados. Diferentemente da sexualidade européia, a ambigüidade que bem caracteriza o gênero travesti é um elemento cultural institucionalizado em muitos povos indígenas. ( $p$ 34)

33 "Just as travestis are not striving for womanhood, neither are they rejecting identity or striving for ambiguity. What they are striving for, they readily tell anybody who will listen, is homossexuality. They desire to embody homossexuality. And they desire to do this in the most complete, beautiful, and perfect manner possible.” (pg 224) 
as travestis em última instância ${ }^{34}$. A questão corporal parece ficar subsumida na de gênero, na medida em que se fala da construção de um corpo feminino, enquanto a da prostituição e a da violência simplesmente desaparecem. Como foi afirmado no começo deste estudo, tal problema parece se uma consequência de como o próprio campo de estudos de Gênero e Sexualidade se estruturou no Brasil e, talvez, no mundo, afirmando tal categoria de uma forma um tanto independente das demais.

Outro ponto a ser destacado refere-se à própria noção de identidade que está por detrás destes estudos. Considerar um fenômeno do ponto de vista da identidade social não significa que estejamos livres de reificá-lo. Certas concepções de identidade, como vimos, parecem carregar em si mesmas certos vieses essencialistas, ao tentar afirmar uma verdade última por detrás da aparente diversidade dos fenômenos. Os estudos considerados parecem, por vezes, reforçar a idéia da existência de uma identidade travesti "monolítica", o que acaba por negar a diversidade e pluralidade sexuais, ao transmitir implicitamente a idéia de que todas as travestis seriam em, última instância, semelhantes. A afirmação da "ambiguidade", da "transcondição", de um "gênero travesti" ou da busca por um "verdadeiro homossexualismo" sugere a existência de uma "verdadeira identidade", que pode ser resumida, de uma forma definitiva. Em nosso entender, mais apropriado seria assumir o estudo da identidade em sua complexidade, muitas vezes em tensão, contradição, permanência e mudança. Não há, portanto, como resumi-la em um elemento central e não será certamente esse o objetivo deste estudo. A impressão que mantenho, após o trabalho de campo realizado com travestis, é de que as "identidades últimas" descritas por estes autores acabam sendo ao mesmo tempo parcialmente acertadas, mas insuficientes, exatamente pelo fato de excluírem a complexidade inerente a este tema em sua análise.

\footnotetext{
34. Uma exceção importante é o estudo de Benedetti (2000), que traz a dimensão corporal como fundamental na constituição identitária das travestis: "O corpo das travestis é antes de tudo linguagem; é no corpo e através dele que os significados do feminino e do masculino se concretizam e conferem à pessoa suas qualidades sociais. É no corpo que as travestis de produzem enquanto sujeitos” (p 46)
} 
Conceber uma identidade como fragmentária, como não-monolítica ou não definitiva ${ }^{35}$, traz à tona o questionamento a respeito de quais fragmentos constituem essa identidade. Implica em se analisar quais os lugares sociais que um determinado grupo ocupa, em quais identidades socialmente reconhecidas sua identidade se apóia. Isso significa dizer que os fragmentos que compõem a identidade tem em si algo de sólido, caso contrário qualquer análise se tornaria inviável. Em relação ao caso das travestis, não é suficiente, embora correto, afirmar a ambiguidade masculino/feminina, propondo que as travestis reproduzam parcialmente a identidade masculina e a feminina ao mesmo tempo. Se há uma identidade masculina (ou feminina) hegemônica, há, como vimos, diversas identidades periféricas que configuram diferentes masculinidades e feminilidades possíveis. As travestis se relacionam não somente com as identidades masculina e feminina dominantes, mas também, e certamente mais do que a grande maioria dos outros grupos sociais, com aquelas tidas como marginais.

\section{Identidade como colcha de retalhos ("patchwork")}

Os estudos clássicos de Psicologia Social vão enfatizar o papel da comparação social como fundamental no processo de formação da identidade social. Para Tajfel (1983), por exemplo, é pelo processo de categorização e comparação social das diferenças presumidas entre os grupos que a identidade social se forma. A identidade social pode ser entendida, então, como resultado de um processo de diferenciação progressiva entre os grupos sociais Embora questionem o caráter universal do modelo de formação da identidade proposto por Tajfel, autores como Doise e Deschamps (apud Amâncio, 1999, p. 299-300) mantém a idéia de que a categorização e comparação sociais tem um papel importante nesse processo.

Ao mesmo tempo, porém, é importante considerar o fato de que, em ambientes sociais complexos, diversos grupos sociais, "portadores" de diferentes identidades, muitas vezes convivem de forma próxima, assimilando características uns dos outros.

\footnotetext{
35 A fragmentação da identidade no universo homossexual masculino a partir da década de 80, em São Paulo, é descrita por Trindade (2004, p 84)
} 
Isso significa dizer que, em alguma medida, há, na formação da identidade de um grupo, a incorporação de características que são definidoras de outras identidades sociais. Propomos considerar aqui que tal processo tem uma importância fundamental na constituição identitária das travestis e que ocorre, no contexto grupal, de forma análoga ao processo de identificação, descrito pela Psicanálise freudiana e que se refere a um processo individual.

A identificação é considerada, na Psicanálise, o mecanismo principal de formação do ego ${ }^{36}$. Em Psicologia de Grupo e Análise do Ego, obra de 1921, Freud (1998) considera esta como o processo pelo qual o próprio ego do indivíduo se modifica, segundo o aspecto de alguém tomado como modelo. Implica, da mesma forma, em uma relação afetiva da criança com a mesma pessoa. As sucessivas identificações tornam o ego necessariamente um tanto quanto fragmentado, uma vez que pressupõem a interiorização de um conjunto de traços muitas vezes incoerentes entre si por parte dos indivíduos. São estas diversas identificações que possibilitam ao sujeito um sentimento de identidade diferenciada.

Uma das decorrências da proposta freudiana é a consideração de que é por uma tentativa inconsciente de se assemelhar aos outros que alguém se torna único. Esta aparente contradição deve-se exatamente à multiplicidade de identificações pelas quais passamos no decorrer de nossas vidas. A "originalidade" de cada um de nós não está em uma diferença essencial que nos constitui, mas sim na configuração específica resultante de nossa busca inconsciente por semelhanças em relação aos outros.

Se considerarmos a constituição da identidade social de forma análoga à descrita por Freud em relação à formação da identidade individual, é possível pensar que alguns grupos sociais, ao incorporar características de outros grupos, tem sua identidade social constituída como uma resultante dessas diversas incorporações. Sua especificidade se dá, então, mais pela singularidade do conjunto do que pela originalidade de suas partes, o que significa afirmar que sua identidade tem um caráter multifacetado exatamente por causa das apropriações de elementos muitas vezes dissonantes entre si.

\footnotetext{
${ }_{36}$ Tal conceito freudiano é analisado por mim em estudo anterior (Garcia, 2004)
} 
Sugerimos considerar tal proposta de entendimento da identidade social usando como metáfora a "colcha de retalhos" (patchwork). No caso das travestis, isso equivale a afirmar que a identidade social (como "colcha") se forma a partir da apropriação de elementos presentes em outras mais solidamente estabelecidas (os "retalhos"). Consideramos que é possível supor que tal processo possa se dar a partir de vivências concretas, pelo compartilhar de espaços sociais em comum, uma vez que "é nos vínculos afetivos tecidos com outros, na possibilidade de dividir objetos e projetos, que se desenvolve o sentimento de identidade" (Giust-Desprairies, 2005, p 211), bem como imaginariamente, pela via, por exemplo, de modelos presentes nos meios de comunicação de massa.

Pensar a identidade como "colcha-de-retalhos" nos permite superar a perspectiva essencializante de identidade anteriormente criticada, voltada à busca por uma "verdade última" por detrás das aparências, e assumi-la em seu caráter histórico, em dinamismo constante. Significa afirmar que a "colcha" está em permanente construção, mas que é possível retratá-la em um momento específico, o que é nosso objetivo neste estudo, com referência às travestis estudadas. Propomos, neste sentido, analisar as masculinidades e feminilidades que são por elas incorporadas, de forma a se tornarem partes constitutivas de sua identidade social. No transcorrer deste estudo, são consideradas como identidades parcialmente incorporadas pelas travestis a "mulher submissa", a "prostituta" e a "mulher super-sedutora" no campo da feminilidade e o "viado", o "malandro" e o "bandido", no campo da masculinidade A forma complexa pela qual elas se articulam para formar a identidade travesti - os "nós", "costuras" e "buracos" da colcha - será objeto de consideração ao final do mesmo. 


\section{GÊNERO}

Analisar a relação que determinadas identidades transgenéricas estabelecem com o sistema de gêneros ocidental, e, mais especificamente, o brasileiro, traz à tona a questão de em que medida tais identidades o reproduzem e em que medida o questionam. Se, como vimos anteriormente, o(a) transexual caminha muito mais no sentido de afirmar a binariedade masculino/feminina do que de negá-la, o que dizer da travesti?

Pesquisas transculturais a respeito da sexualidade mostram que a binariedade de gêneros está distante de ser algo universal, como podemos observar nos estudos sobre o berdache entre os indígenas norte-americanos (Roscoe, 1994) e sobre os hijras na Índia (Nanda, 1994). Embora existam outros gêneros, além do masculino e do feminino, em outros contextos culturais, nas sociedades ocidentais a binariedade se impõe de forma bastante evidente. Como adverte Lewins (1995), o desejo de que a sociedade não seja dualista não pode obscurecer a percepção de que estamos em uma "gendered society" (pg 159). Atribuir, portanto, às travestis o poder de viver "fora" desta divisão binária seria considerá-las, como estando "fora" da sociedade, algo que não seria pertinente em nossa abordagem.

Antes de considerar a complexidade das relações estabelecidas pelas travestis pesquisadas em diferentes contextos relacionais, o que mostra uma configuração bastante original do grupo em relação ao sistema de gêneros masculino/feminino, é interessante refletir sobre esta relação a partir do impacto que as travestis causam comumente nas pessoas.

Recordo de maneira muito clara o primeiro encontro do Grupo que tomei parte. Embora tivesse tido experiência de trabalho prévia com travestis, em contexto individualizado, no período de 1994 a 1997, quando funcionário do Centro de Referência e Treinamento em DST/AIDS, da Secretaria de Estado da Saúde, e tivesse 
tido por vezes uma sensação de estranhamento, essa em nada era comparável à que foi por mim experienciada em meu primeiro dia no Grupo. Enquanto as pessoas que vivem nas grandes cidades estão, em maior ou menor grau, acostumadas a ver travestis nas ruas se prostituindo, devidamente vestidas e montadas, nos encontros estas estavam quase sempre em trajes cotidianos, sem a preocupação de ressaltar os traços femininos. Embora algumas mesmo assim se aproximassem do padrão feminino de aparência, causando menos estranhamento, a maioria apresentava uma mistura de traços masculinos e femininos, ou, melhor dizendo, de traços hiper-masculinos e hiperfemininos. Não se tratava assim de uma androginia, onde há uma predominância de traços que não se remetem de forma evidente aos masculinos ou femininos, mas de uma mistura de traços que remetem claramente aos dois gêneros. Se os traços femininos diziam respeito principalmente aos cabelos, gestuais e às formas corporais modificadas por hormônio e silicone, os masculinos diziam respeito ao porte físico e feições faciais, que entre aquelas travestis de baixa renda se assemelhavam, não por acaso, aos de operários e trabalhadores da construção civil, segmentos estes que reproduzem uma masculinidade típica de camadas populares. Pode-se pensar que as "dragões" geraram em mim naquele momento uma vivência típica de relação com o monstruoso'.

Foucault (2001), em seu curso de 1975 no College de France, intitulado "Les Anormaux", trata do tema da mostruosidade de forma bastante instigante. Observa que, da Idade Média ao início do século XVII, o monstro se define a partir da mistura, seja de dois reinos, como o animal e humano (homem/touro), de duas espécies (por exemplo, porco com cabeça de carneiro), de dois indivíduos (siameses) ou de dois sexos (hermafrodita, mulher barbada) e é personagem frequente dos circos de então. A partir do final do século XVIII passa a ser visto cada vez mais como uma figura que questiona

\footnotetext{
1 Obviamente esta é uma sensação que se desfaz gradualmente com a convivência com o grupo, mas parece ser bastante comum entre as pessoas não familiarizadas com travestis. Por diversas vezes pude presenciar olhares assustados, de estranhamento, muitas vezes acompanhados por comentários jocosos direcionadas a elas. Como resposta, estas buscam frequentemente não "chocar" as pessoas, andando em pequenos grupos, olhando para baixo. Em uma visita com cerca de 20 travestis a um Centro de Referência de AIDS municipal, situado a poucas quadras, notei que estas se dispersaram rapidamente pelo caminho, se reagrupando somente na entrada do referido prédio. Quando indaguei sobre o porque não andavam juntas, uma delas respondeu que várias travestis “em bando” causavam muito escândalo e por isso era melhor se separarem nessas ocasiões.
} 
não somente as leis da natureza, mas também as da sociedade, combinando o impossível, algo pertinente à natureza, com o proibido, que pertence ao domínio jurídico. O monstro não é contra a lei, na medida em que a lei não o prevê. Ele é o impensado, o fora-da-lei. Dessa forma suscita entre as pessoas não a imposição da lei, mas a supressão pura e simples. Por representar, para o autor, o modelo ampliado de todas as imperfeições e irregularidades possíveis, o monstro configura-se como "a forma natural da contranatureza"(p. 70).

No século XIX a figura do monstro, para Foucault (2001), se funde a outras, como a do indivíduo a ser corrigido e a do masturbador, gerando o indivíduo anormal, que passa a ser "um monstro cotidiano, um monstro banalizado" (pg. 71). A Medicina e o Direito buscam o que há de monstruoso em cada anormal. O monstro é desta maneira domado pelas concepções médicas, o que pode ser observado no caso do hermafroditismo. Neste momento histórico, não mais se concebe o hermafroditismo como mistura "verdadeira" de dois sexos, passando a haver o entendimento de que há sempre a predominância de um deles, com o outro sendo mero apêndice. Passa-se a conceber a Natureza como sujeita a deslizes e imperfeições que necessitam ser catalogadas. A classificação das diversas anomalias correspondem, assim, à domesticação do que é considerado monstruoso.

Se aplicarmos essas observações de Foucault aos quadros médico-psiquiátricos de travestismo e transexualismo, descritos no capítulo anterior, fica evidente esse processo de domesticação. A condição dos indivíduos que atravessam os limites imaginados que definem os gêneros masculino e feminino passa a ser catalogada, constituindo anomalias perfeitamente classificáveis segundo critérios estritos.

Tendo a obra de Foucault como um de suas referências, Judith Butler (1993) observa que os sistemas de saber e poder criam territórios de inteligibilidade, mas também seu exterior. Há sempre algo que é excluído pelos domínios de inteligibilidade presentes em uma dada sociedade (p. xi), ou seja, há sempre algo "de fora" daquilo que sabemos e definimos a partir da razão. Se entendemos a Natureza, assim como as ciências que dela se ocupam, como a Biologia, como criações discursivas, a definição do que é "natural" necessariamente cria o que é não-natural, os domínios do grotesco, do monstruoso, ou, se utilizarmos o termo foucaultiano, do "contra-natural". Butler 
(1993, p 190) chama de "abjetas" as organizações da sexualidade que excedem à estruturação ditada pelas normas, barradas de inteligibilidade cultural. Essa abjeção é uma consequência da forma como o sistema de gêneros nas sociedades ocidentais se organiza, a partir do que a autora denomina "matriz heterossexual". Tal matriz implica no entendimento da masculinidade e da feminilidade como binárias e oposicionais e na concepção de que estas entidades se atraem mutuamente, uma vez que o desejo é entendido como sendo sempre heterossexual. ${ }^{2}$

Argumento semelhante é desenvolvido por Haraway (1992), retomando o conceito de "inappropriate/d others" de Minh-ha ${ }^{3}$, conceito este que se refere ao posicionamento daqueles que não ocupam o lugar do "self" ou do "outro" oferecidos pelas narrativas ocidentais modernas de identidade. Estes "outros inapropriados" não cabem nas taxonomias e estão deslocados dos mapas acessíveis que especificam os tipos de atores e de narrativas existentes, estando, portanto, fora dos territórios da racionalidade. Daí o duplo sentido do termo: são "inapropriados" por não serem "apropriados" pelos domínios de inteligibilidade existentes e por não ocuparem as posições de sujeito "apropriadas”, o que gera intensa marginalização.

Seguindo-se esta discussão, levantamos aqui a possibilidade da travesti ser entendida como uma figura que excede às classificações normativas associadas ao gênero e sexualidade presentes em nossa sociedade. Tornada possível pela apropriação particular de algumas tecnologias médicas, a travesti parece corresponder ao ressurgimento da figura monstruosa descrita por Foucault, não classificada ou prevista pelo aparato médico-jurídico. Da mesma forma, configura-se como um "outro inapropriado", por reivindicar um lugar social não reconhecido como legítimo, pertencendo aos domínios do "abjeto", daquilo que se situa, em larga medida, fora dos sistemas de saber e poder estabelecidos. Ao fazê-lo, as travesti nos desafiam, nos desconstróem, nos suscitam eliminação pura e simples, como as figuras monstruosas

\footnotetext{
${ }^{2}$ Não se concebe, por exemplo, o desejo do masculino pelo masculino em uma relação homoerótica, uma vez que presume-se que o desejante ou o desejado ocupem um lugar feminino.

s MINH-HA, Trinh T. Woman, Native, Other. Writing postcoloniality and feminism. Indiana University Press, 1989
} 
descritas por Foucault, mas também permitem que nos questionemos sobre quais os campos de saber e poder que construímos.

O desejo de eliminação das travestis, por ocuparem um lugar que excede a inteligibilidade cultural da matriz heterossexual, era claramente perceptível nos relatos das travestis do Grupo. Se utilizamos com frequência o termo "homofobia" para designar o preconceito e a discriminação voltada a indivíduos com preferência homoerótica, podemos utilizar o termo transfobia como mais apropriado para designar tais fenômenos, ainda mais intensos, em relação às travestis. Entre elas a transfobia se manifestava envolta em formas extremas de violência. Por envolver muitas vezes situações onde outros atores sociais frequentes no universo das travestis, como policiais e clientes, estavam presentes, será objeto de consideração mais adiante em nosso estudo, em um capítulo específico. Como exemplo inicial, porém, é interessante resgatar aqui uma conhecida figura histórica que mostra a transgressão às normas relacionadas ao sistema de gêneros no Brasil: trata-se de "Madame Satã", que viveu no Rio de Janeiro entre as décadas de 10 e de 60 do século passado.

Green (2000) mostra "Madame Satã"4 como uma personalidade controvertida da vida da Lapa carioca, que se considerava ao mesmo tempo "malandro" e "bicha", por preferir se relacionar sexualmente de forma passiva. Um dos relatos das "Memórias de Madame Satã" citados por Green (2000, p. 155-6) diz respeito ao fato dos policiais prenderem indivíduos efeminados em locais de concentração homoerótica apenas para fazer a faxina das delegacias, fato com o qual ele se rebelava. Há aqui a presença de uma forma de humilhação para com estes indivíduos, mas ao mesmo tempo a pressuposição de que os mesmos deveriam realizar as funções tidas como tipicamente femininas. Se considerarmos a violência e a agressão como atributos masculinos em nossa cultura, como mostra Parker $(1992)^{5}$, a contradição no comportamento de

\footnotetext{
4 A história de "Madame Satã" inspirou o filme "A Rainha Diaba", de 1971, dirigido por Antônio Carlos Fontoura e foi retratada no filme homônimo, de 2002, dirigido por Karim Ainouz.

${ }^{5}$ Um dos argumento de Parker (1992) neste sentido é em referência ao fato de muitos termos de nossa língua serem utilizados igualmente como referência aos órgãos e comportamento sexual masculino ou a formas e instrumentos de agressão Como, por exemplo, "cacete", "pau" e "pistola", como referências concomitantes ao pênis e a instrumentos de agressão; "porrada" como referência 'a ejaculação, mas também a um golpe agressivo em alguém; "foder", como um ato sexual mas também como um sinônimo
} 
"Madame Satã" parece estar no fato de responder à agressão sofrida por ser "bicha", ou seja, feminino, com violência, um atributo considerado masculino, desafiando a obrigatoriedade do pertencimento a uma das polaridades - masculina ou feminina - e gerando ainda mais preconceito e violência. $O$ que transparece na história de Madame Satã, assim, é que, paralelamente a uma violência de gênero direcionada ao feminino, outra mais intensa aparece direcionada a quem não reproduz a binariedade esperada. A história de contravenções e prisões pelas quais passa "Madame Satã" é muito mais longa e notória do que a sofrida por outros homens que correspondiam mais proximamente ao que é considerado como tipicamente feminino ${ }^{6}$.

Em relação às travestis, é bastante provável que a violência a elas direcionada tenha como um de seus determinantes o fato das mesmas não ocuparem um local definido nos "catálogos" identitários reconhecidos na sociedade brasileira. Tal fato suscita reações adversas mais intensas do que as direcionadas aos segmentos que ocupam um lugar periférico, ainda que estigmatizado, como ocorre, por exemplo, no caso de homossexuais não-transgêneros ou prostitutas. Silva (1993, p 109), nesse sentido, considera que as travestis sofrem perseguição não por ocupar um lugar feminino, mas pela pretensão à transitividade e por escapar à classificação social”"7

de submeter alguém a uma ato de violência física ou de outra ordem; etc. Connell (1997) aponta esta conexão entre masculinidade e agressividade como algo comum nas sociedades contemporâneas.

${ }^{6}$ Clastres (2003), em seu clássico ensaio de 1966 "O Arco e o Cesto", mostra de forma magistral a diferença entre estar no lugar social "errado" e não estar em lugar algum. Em seu estudo sobre os índios nômades amazônicos Guayaki, observa que há entre estes uma divisão absoluta entre os papéis dos homens e das mulheres em relação ao trabalho, onde os primeiros caçam e coletam recursos naturais da floresta enquanto as últimas se dedicam à fabricação de instrumentos, ao cuidado dos filhos e ao transporte dos bens familiares. Tal divisão gera uma outra, entre um espaço masculino, a floresta, e um feminino, o acampamento, e se reflete no uso do arco como um instrumento masculino e do cesto como feminino, instrumentos estes que não devem ser tocados por uma pessoa do sexo que não lhe corresponde. Em tal sociedade, o autor descreve dois indivíduos que não ocupavam o lugar social esperado. Um deles, no entanto, ocupava o lugar feminino, vivendo entre as mulheres, mantendo os cabelos mais longos e executando somente trabalhos femininos, sendo proprietário de um cesto. Por isso, não despertava nenhuma atenção especial. O outro, ao contrário, era considerado pane - o que naquela sociedade significava ter o azar na caça - não acompanhava os outros homens em suas expedições e não possua arco, o que fazia com que não conseguisse uma esposa e fosse "eliminado do círculo dos homens, sem, entretanto, com isso integrar-se ao das mulheres" (p. 127), tornando-se objeto de desprezo por parte de todos. Por não ocupar um lugar social identificável, para o autor, esse indígena introduzia no sistema Guayaki uma elemento de desordem, sendo por isso objeto de escárnio naquela cultura.

${ }^{7}$ Kulick (1998) desenvolve um argumento diferente. Para ele as travestis somente são objeto de escárnio quando não conseguem ser sexualmente atrativas e não pelo fato de serem transgêneros por si só (p 235 ). 


\section{Origem social das travestis}

O Grupo objeto deste estudo era frequentado basicamente por travestis oriundas de famílias de baixa renda. Obviamente trata-se aqui de uma amostragem "viciada" em relação às travestis em sua totalidade, uma vez que este, por suas características e localização, atraía basicamente travestis de baixa renda. Outros estudos, porém, como os de Kulick (1998), Benedetti (2000) e Ferreira (2003), são concordantes em relação à hipótese de que a grande maioria das travestis brasileiras seja oriunda destes segmentos. Tal consideração levanta imediatamente a questão de haver ou não alguma relação entre a forma como o sistema de gêneros é estruturado em camadas populares no Brasil e a própria existência das travestis enquanto grupo social.

Um das interpretações possíveis frente à relação entre sistema de gêneros e segmentos de renda no Brasil é a de que a valorização da masculinidade é maior nas camadas populares em nosso país como compensação para a escassez de recursos que tais camadas tem em outras esferas, proposta feita por Pedro Oliveira (2002) em seu estudo sobre a construção social da masculinidade. A afirmação da identidade masculina se faria mais necessária nessas camadas em função de haver uma diminuição do poder de atuação e intervenção em diversas esferas da vida social (pg. 246). Isso poderia nos levar à hipótese de que uma demarcação mais rígida entre os gêneros masculino e feminino, nestas camadas, levaria alguns indivíduos homossexuais a procurar por um lugar feminino de forma incisiva, buscando inclusive transformações corpóreas para fazê-lo, como no caso das travestis ${ }^{8}$, enquanto em segmentos de renda médios e altos haveria maior tolerância à expressão da

\footnotetext{
Esta interpretação, porém, pode ser objeto de questionamento, uma vez que é provável que o que o autor esteja chamando de "ser sexualmente atrativa" esteja relacionado a ter aparência mais feminina. Neste sentido, a travesti que tem mais atributos femininos se aproxima mais de um lugar social definido, deixando de desafiar - ou o fazendo em menor grau - o sistema de gêneros binário, o que aumenta a possibilidade de ser socialmente aceita.

8 Essa hipótese me foi sugerida, em comunicação pessoal, pelo próprio Pedro Paulo Oliveira (outubro de 2002) e por José Moura Gonçalves Filho (abril de 2004). Hipótese similar em relação a outra modalidade de transgêneros, no contexto norte-americano, é feita por Newton (1979) que relaciona os(as) transformistas estudados(as) a sua origem social, geralmente de cidades pequenas do sul e meio-oeste dos EUA, onde impera um sistema moral mais rígido, tipicamente rural.
} 
feminilidade por parte de indivíduos com as mesmas características, que não necessitariam desta forma buscar por tais transformações.

Embora tentadora, tal hipótese pode ser objeto de questionamentos. O primeiro deles refere-se à questão de como as regras e valores de um determinado segmento social são de fato incorporadas por ele. Pollak (1987), revendo estudos sobre homossexualidade na Alemanha e Estados Unidos na década de 70, sustenta a tese de que nas camadas populares destes países

\footnotetext{
“a socialização é muito rígida e definida em termos de proibição e de exigências relativamente claras" [mas] “as crianças são menos vigiadas de modo permanente" [o que faz com que] "as normas bastante estritas próprias à socialização das camadas populares sejam muitas vezes seguidas sem serem interiorizadas” (pg 63).
}

Isso explicaria para este autor o início de uma vida sexual frequente desde cedo e a permanência de atividades sexuais de forma intensa após os 40 anos entre homossexuais das camadas populares destes países, fato que não ocorre entre os de camadas de alta renda.

Um segundo questionamento possível refere-se ao fato de se tomar as camadas populares como um todo homogêneo, coisa difícil de se afirmar no Brasil. O estudo de Benedetti sobre travestis de Porto Alegre, por exemplo, traz hipótese contrária à levantada acima, em relação à Região Sul do Brasil. Benedetti (2000) constata a existência de poucas travestis oriundas das regiões de colonização italiana e alemã, majoritariamente de segmentos de renda médios, em comparação com aquelas que se caracterizam pela miscigenação entre portugueses, negros e índios e considera ser “impossível não dissociar a rígida moral católica e a dura ideologia alemã no que concerne às diferenças entre os gêneros do pouco espaço social para sexualidade e gêneros diferentes nestas regiões" (pg 31). No caso da Região Sul, para ele, portanto, os valores de gênero menos rígidos parecem estar mais associados às camadas populares.

Apesar de não ser o objetivo deste estudo comparar diferentes modalidades de transgêneros, é interessante levantar algumas hipóteses alternativas à apresentada acima como contribuição para esse debate. Duas profissionais que trabalham em 


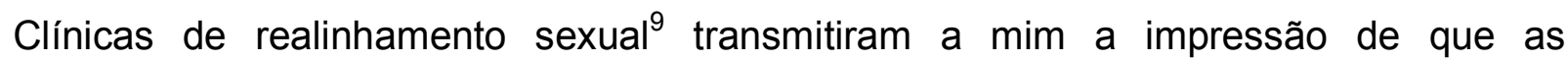
transexuais que buscam por cirurgia de mudança de sexo são comparativamente oriundas de segmentos de renda mais alto do que as travestis ${ }^{10}$. O mesmo certamente ocorre com as "drag-queens", personagens que se disseminaram pela noite paulistana a partir da década de $90^{11}$. Comparando tais realidades com a das travestis, pode-se pensar que o fato das últimas serem oriundas principalmente de segmentos de baixa renda, portanto, não se deve à existência de normas de gênero mais rígidas, mas sim à própria dinâmica da prostituição, que as direciona para uma identidade transgenérica específica, diferente das citadas. O menor investimento em educação desde a infância e o fato de haver poucos recursos financeiros na família para o direcionamento para outras ocupações faz com que esta seja em grande parte das vezes a única alternativa para transgêneros oriundos(as) de camadas populares. A constituição das travestis como um grupo social com identidade específica é, portanto, inseparável da prostituição.

Em relação à origem geográfica, no Grupo havia uma clara predominância de travestis oriundas das regiões Norte e Nordeste do país. Em um dos encontros, tal origem foi contabilizada. Naquela ocasião, com onze travestis presentes, sete eram de estados do Norte ou Nordeste e quatro do Sudeste. A proporção das que vinham das capitais ou regiões metropolitanas em relação às oriundas do interior dos estados também era de quatro para sete. Se a origem predominantemente de segmentos populares é algo que parece comum em relação às travestis brasileiras, como foi

\footnotetext{
${ }^{9}$ Refiro-me a Maria Jaqueline Coelho Pinto, membro da Equipe Multidisciplinar de Adequação Sexual da Faculdade de Medicina de São José do Rio Preto - FAMERP (comunicação pessoal em março de 2003) e a Kathya Regina Mutti, membro do Prosex do Instituto de Psiquiatria do Hospital das Clínicas da Faculdade de Medicina da Universidade de São Paulo (comunicação pessoal em junho de 2002).

${ }^{10}$ Benedetti (2000) refere que as transexuais no Brasil tem escolaridade mais alta, o que as leva a ter acesso à bibliografia existente sobre sua condição, especialmente à de origem médica-psiquiátrica, que como vimos, reifica sua condição (p 112)

${ }^{11}$ Os perfis de várias drag-queens descritos por Palomino (1999) mostra uma frequência quase exclusiva a locais de segmentos de renda alto e médio, além de uma escolaridade certamente maior do que a da grande maioria das travestis. A "montagem" das drags envolvem custos consideráveis, uma vez que as roupas e adereços não costumam ser repetidos. Conclusão semelhante pode ser abstraídas do estudo de Vencato (2005) com drag-queens de Florianópolis, que chama atenção especificamente para as caras maquiagens utilizadas.
} 
observado anteriormente, a origem geográfica nortista/nordestina não ${ }^{12}$. Uma interpretação possível em relação à maior frequência de travestis nortistas/nordestinas no Grupo é a de que talvez exista uma correlação entre origem geográfica e padrão de beleza requerido pelos clientes: as travestis com traços que revelam ascendência européia, mais comuns em estados do Sul e Sudeste, talvez sejam preferidas pelos clientes com maior poder aquisitivo, o que faz com que acabem se situando entre os segmentos de travestis com renda mais alta. No caso do Grupo, poderíamos supor que havia predominância de travestis destas regiões brasileiras justamente por este concentrar travestis de baixa renda ${ }^{13}$.

\section{Infância e Adolescência}

Traçar uma história de vida comum às travestis é algo que pode ser criticável por duas razões. A primeira delas refere-se às generalizações indevidas que podem ser feitas, uma vez que certamente há diferenças profundas em relação a sua história familiar e de vida. A segunda refere-se ao fato de estarmos lidando com um discurso sobre o passado. Se considerarmos o tornar-se travesti como um processo de ressocialização, como será defendido mais adiante, é lícito supor que o passado descrito "é reinterpretado para se harmonizar com a realidade presente, havendo a tendência a retrojetar no passado vários elementos que não eram acessíveis naquela época" (Berger e Luckmann, 1966, p. 215). Respeitadas estas limitações, contudo, a abordagem da história da infância e adolescência é importante, na medida em que elas determinam para as futuras travestis a assunção da identidade de "viado" ou "bicha", que se configura como um elemento importante a constituir a identidade travesti posterior.

\footnotetext{
12 Como exemplo contrário, podemos citar a predominância de travestis gaúchas no estudo de Benedetti (2000) em Porto Alegre. Os dados das reuniões para travestis o Gapa da mesma cidade, citados por Florentino (1998) mostram que 84\% delas eram oriundas do próprio estado do Rio Grande do Sul.

${ }^{13}$ Green (2000), em consulta aos arquivos de Guido Fonseca, delegado de polícia da região central de São Paulo que documentou as travestis detidas naquela área, no biênio 1976-7, refere que 40 \% delas eram naturais do estado de São Paulo.
} 
Nos relatos das travestis pesquisadas apareceram com frequência episódios mostrando o desajustamento delas em relação ao que era esperado de um menino em suas famílias e comunidades de origem. A preferência por companhias e brincadeiras tipicamente femininas eram repetidamente evocadas, de forma paralela ao afastamento do grupo de meninos e de suas brincadeiras. A impressão que esses relatos me deram desde o princípio foi a de que estes futuros travestis viviam em um universo dominado pelas mães, tias e outras familiares do sexo feminino. ${ }^{14}$

O pertencimento a um universo marcadamente feminino parece ser relevante para se entender o posicionamento social destes futuros travestis. Não estamos aqui afirmando que estes meninos "viraram" travestis por causa de suas famílias. Tal consideração a respeito de uma origem do travestismo só faria sentido em uma abordagem essencialista, que considerasse tal quadro como um distúrbio, nos moldes da abordagem de Stoller (1982) que busca identificar a etiologia familiar do transexualismo ${ }^{15}$. Por outro lado, não podemos desprezar tal influência como irrelevante ${ }^{16}$. Há relatos de travestis que remetem a processos precoces de ruptura com as expectativas relacionadas ao sexo masculino, que são inclusive tolerados pela família:

S. contou que sempre teve cabelo comprido na infância devido a uma promessa que sua mãe havia feito quando grávida. Aos sete anos, momento em que a promessa se encerrava, S. se recusou a cortar o cabelo. Pressionado pela família, concordou em cortá-lo, desde que o deixassem “compridinho” (fez o gesto mostrando que teria ficado na altura dos ombros).

\footnotetext{
14. A localização pelo desejo de transformação ainda na infância é citada por Benedetti (2000, p 95). |Segundo Pelúcio (2005a), ser travesti é um imperativo que as acompanha desde a infância. Para Silva (1993, 146), contudo, a história de vida é convocada como um dos elementos para a construção de uma mulher, ao lado de outros como o corpo ou a forma de se vestir, o que sugere a possibilidade de ressignificação do passado, citada anteriormente.

${ }_{15}$ Para Stoller (1982) o transexualismo corresponde a uma não-superação da fase simbiótica em que o menino se identifica com a mãe, o que o leva a se comportar permanentemente como menina. Caracteriza-se, portanto, pelo prolongamento da fase simbiótica e pela ausência do conflito edípico, uma vez que não há a castração.

${ }_{16}$ Penso que é possível uma posição ponderada a respeito deste tema. Isso significa que devemos levar em conta tanto argumentos como o de Connell (1995, p. 190), que considera que as narrativas que vêem o gênero como um molde social cuja marca é estampada na infância desprezam a dimensão ativa de uma pessoa em crescimento, quanto estudos que mostram que as identidades de gênero se constroem fortemente já na primeira infância, como o de Duveen (2001).
} 
Um dos pontos em que um possível lugar ambíguo de gênero dentro da família podia ser observado - e que tem a vantagem de não ser algo passível de ressignificação, como as memórias da infância - é o da própria nomeação das crianças. Embora nos encontros não fossem identificadas pelos "nomes de homem", que constavam em seus documentos, as travestis os diziam em alguns contextos. Grande parte destes nomes eram ambíguos em relação à qual sexo poderia se referir ${ }^{17}$. As próprias travestis atribuíam às vezes a escolha de seus nomes a um desejo familiar de se ter uma menina como filha.

Um outro fato que chamou minha atenção em relação à estrutura familiar era o de ser significativo o número de famílias em que havia mais de uma travesti, o que pode estar relacionado a um lugar de ambiguidade atribuído aos meninos nas mesmas:

B chegou atrasada e ao sentar logo gritou: "Primo!", para outra travesti que estava vindo pela primeira vez. A situação foi engraçadíssima. B. disse em um certo momento:"não acredito que você também virou bicha!". Depois as duas contaram que vem de uma família onde tem muitas travestis. Perguntei quantas e elas listaram 13 !!! travestis, entre tias e primas.

Se parecia haver uma certa aceitação em relação aos meninos futuros-travestis por parte das mulheres da casa, os homens, em sua grande maioria, os rejeitavam. Desde pequenos eram objeto de escárnio dos irmãos, primos e colegas. Cedo começavam as ofensas, as alcunhas de "bicha" ou "viado" e também as agressões. Episódios de violência sexual, muitas vezes intra-familiar, pareciam ser comuns nesse período $^{18}$. De forma bastante contraditória, o abuso sexual era tido como um castigo merecido pelo menino efeminado por parte dos abusadores ${ }^{19}$ :

\footnotetext{
${ }^{17}$ Lembro-me particularmente dos "nomes de homem" de quatro travestis bastante frequentes no Grupo, que por motivos éticos não podem ser reproduzidos aqui.

${ }_{18}$ Novamente é importante aqui ressaltar a importância de não universalizar a questão do abuso sexual e de não estigmatizar ainda mais a travesti em função de sua possível ocorrência. A patologização da infância a partir de análises psicologizantes é citada como comum nos discursos relacionados à prostituição na França por Welzer-Lang (1994, p 69) e na São Paulo do início do século XX por Rago (1991, p 21).

19 Trevisan (2000) cita como recorrente no Brasil este tipo de "castigo" sexual ao menino efeminado. (p. $417)$.
} 
S. me chamou em separado depois do encontro e falou que estava com um "problema de cabeça”. Lembrava continuamente de uma situação de abuso pelo pai na sua infância. Disse que muitas vezes em que estava "dando" para alguém se lembrava desta situação e não consegue tirar da cabeça. Sugeri a ela que iniciasse uma psicoterapia ${ }^{20}$.

As experiências sexuais voluntárias, isto é, excluídas aquelas que poderiam ser definidas como abuso sexual ou como incesto, eram referidas também como sendo bastante precoces. Iniciavam-se com o "troca-troca", prática comum no Brasil (Parker, 1995, p. 245) e que se caracteriza por um menino esfregar o pênis - em alguns casos penetrá-lo - no ânus do outro, com a posterior inversão dos papéis. A preferência pelo papel passivo levava esses meninos futuros-travestis a serem preferidos como parceiros de troca-troca, realizando-o muito frequentemente. Alguns deles já tinham vida sexual intensa e regular ao redor dos 10 ou 11 anos. Entre estas práticas, as mais comuns eram sexo oral ativo, sexo anal passivo e masturbação de algum outro jovem da mesma idade ou um pouco mais velho.

A efeminação e a realização de práticas homoeróticas acabavam muitas vezes por ser objeto de comentários nas comunidades em que viviam. As reminiscências das vivências escolares entre as travestis do Grupo, por exemplo, eram entrecortadas pela lembrança de episódios de intensa discriminação, o que levava muitas delas a abandonar o estudo também precocemente ${ }^{21}$. Isso contribuía para gerar um aumento da perseguição por parte da família. Quando este processo se intensificava, grande parte dos futuros travestis acabavam por buscar um outro local de moradia ou eram

\footnotetext{
${ }^{20}$ Embora atuasse também como psicoterapeuta na referida instituição, preferia não atender as travestis em psicoterapia por imaginar que isso poderia gerar algum tipo de rivalidade no Grupo, pelo fato das travestis, bastante competitivas, interpretarem tal fato como um favorecimento de uma delas de minha parte. Neste e em algumas poucos outros casos, especialmente de dependência de drogas, cheguei a encaminhar as travestis para outro psicólogo ou para um psiquiatra da instituição, que no meu entender poderiam atendê-los de forma não-discriminatória. Tais encaminhamentos raramente eram bemsucedidos, uma vez que quase sempre as travestis faltavam nas primeiras consultas.

${ }_{21}$ Várias travestis do Grupo eram iletradas. Quando comecei a participar do mesmo, havia um controle da frequência - que se fazia necessário em função da prestação de contas em relação à distribuição de preservativos realizada - feito por meio de um livro, onde as mesmas escreviam seus nomes, geralmente os femininos. Observei que várias não sabiam escrever seus nomes. Por conta disso, alguma amiga próxima escrevia para elas. Caso tivessem vindo sozinhas, as travestis geralmente simulavam uma escrita do nome com uma espécie de garrancho, de forma a não transparecer que não sabiam escrevê-lo. Após algum tempo, sugeri que tal prática fosse abolida, em virtude do constrangimento que gerava, e o Grupo a substituiu por uma espécie de "chamada", onde alguma travesti se oferecia para atestar a frequência.
} 
expulsos, saindo de sua cidade de origem muitas vezes bastante jovens (por volta de 14 ou 15 anos).

A busca pela "cidade grande" ainda no início da adolescência é citada como comum por diversos pesquisadores do universo das travestis no Brasil, como Benedetti (2000, p 97), Kulick (1998, p 179) e Pelúcio (2005b). Tal busca, para estes autores, possibilita ao mesmo tempo a liberdade frente às pressões da família, permitindo a expressão da própria sexualidade, e a obtenção de ganhos financeiros, considerados difíceis no local de origem, não somente pelas poucas possibilidades de trabalho existentes, o que motiva a migração de muitos segmentos sociais pelo Brasil afora, mas pelo estigma que passa a pesar sobre o jovem "bicha'. Essa conjunção é apontada por Parker (2002) como frequente entre homens com preferências homoeróticas no Brasil ${ }^{22}$ :

\footnotetext{
Para os homens que foram criados no interior, em áreas rurais ou pequenas cidades, a nova abertura, o anonimato e a tolerância das capitais estaduais ou regionais como Fortaleza [cidade analisada pelo autor] podem representar um enorme alívio. Para homens que cresceram nessas cidades, contudo, o peso da vigilância familiar, a pressão social da vizinhança e assim por diante podem ser excessivos, e fugir para cidades grandes como o Rio de Janeiro ou São Paulo passa a ser uma alternativa. Em ambos os casos, contudo, o deslocamento torna-se uma parte fundamental da busca por uma vida melhor, e a idéia do que de fato constitui "melhor" leva em conta não só a oportunidade econômica, mas também o meio social e, fundamentalmente, a liberdade sexual” (p 251-2)
}

A migração para a cidade grande, porém, traz como consequência o isolamento social como fruto do rompimento com a família, algo citado como comum também em outros contextos sociais, como entre gays norte-americanos (Rubin, 1999, p 160).

\section{O "viado" ("bicha")}

Se na cidade de origem a identidade de "viado" ou bicha" já era atribuída às travestis investigadas, na "cidade grande" tal identidade passava a ser ainda mais

\footnotetext{
22 Também citado por Green (2000), que vê São Paulo e Rio de Janeiro como dois grandes pólos de atração para homossexuais que fogem das pressões familiares, ao longo do século XX (p. 34-5 e 255).
} 
fortalecida, pela convivência próxima a outros homossexuais, que passavam a fornecer um rede social de apoio alternativa à família. Pode-se afirmar, neste sentido, que muitas as travestis passaram por um período de vida anterior em que basicamente se reconheciam e eram reconhecidas como "viado" ou "bicha"

Como foi apontado anteriormente, Kulick (1998), em pesquisa sobre travestis de Salvador, postula que as travestis se identificam como as verdadeiras "bichas" ou "viados", no sentido de que levam às últimas consequências tal identidade. Embora tal proposta seja interessante, é, como vimos, insuficiente para contemplar a identidade travesti. O mais apropriado, em nosso entender, seria considerar a identidade de "viado" como um dos componentes de sua identidade travesti, talvez o mais antigo deles. O uso dos termos "bicha" e "viado" como auto-referência ou para referência mútua entre travestis não significa desta forma que elas se identifiquem de forma absoluta com tais termos, mas parece ser antes uma reminiscência de períodos anteriores da vida de cada uma.

Os termos "bicha" e "viado" tem origem, como vimos anteriormente, em uma classificação dos indivíduos com preferências homoeróticas entre ativos e passivos, classificação esta hegemônica no Brasil até os anos 70 do século passado e ainda bastante presente em diversas regiões brasileiras. Tais termos correspondem à polaridade passiva. Parker (1992) coloca a figura do "viado" como o contraponto à figura do pai e do machão na cultura sexual brasileira, constituindo uma ameaça, ao lado da figura do "corno", ao ideal da masculinidade centrado na idéia de "força, poder, violência, agressão, virilidade e potência sexual” (p. 74).

Ao se identificarem desta maneira, as travestis pesquisadas se identificavam também com a idéia de passividade ${ }^{23}$ e de efeminação que seria próprios dos "viados" ou "bichas". Ao fazê-lo, colocavam-se muitas vezes de forma antagônica aos "ativos", desqualificando-os. Era frequente entre elas a crítica a homossexuais de aparência mais máscula, especialmente àqueles que se relacionavam sexualmente de forma

\footnotetext{
${ }^{23}$ Benedetti (2000, p 119), de forma concordante, considera que as travestis situam todas as pessoas que tem desejos sexuais por homens no pólo passivo.
} 
passiva. Para elas, eram homossexuais que não conseguiam se assumir, e portanto, não o eram por inteiro:

Em meio à discussão da eleição para prefeito [onde um dos candidatos era Marta Suplicy, conhecida por ser defensora dos direitos das minorias sexuais], D afirmou categoricamente que jamais votaria em uma mulher que era a favor de "homem ficar beijando homem"24.

De forma semelhante, havia uma frequente desvalorização dos clientes, especialmente dos chamadas "mariconas", homossexuais mais velhos e, como veremos, dos "maridos" que se mostrassem sexualmente "passivos" em algum momento.

\section{Tornando-se travesti}

$\mathrm{Na}$ história de vida contada várias vezes nos encontros, a chegada à cidade grande estava associada também ao ingresso na prostituição. Os jovens "bichas" e "viados" tinham esta como uma das únicas alternativas financeiras. Essa fortíssima associação entre travestis e prostituição ${ }^{25}$, a ser explorada mais extensamente em capítulo específico, se deve a várias razões. A primeira delas relaciona-se à impossibilidade de recorrer à família frente a uma situação de desemprego. Outro motivo, apontado por Kulick (1998), refere-se ao impedimento do acesso a algumas ocupações típicas de segmentos populares, motivado pelo preconceito contra homossexuais efeminados (p.118). Outra razão aparente diz respeito à baixa qualificação profissional, devido ao pouco investimento pessoal ou familiar no estudo (Ferreira, 2003, p 118), também afetado, como vimos, pela discriminação no cotidiano escolar. O recurso de jovens efeminados à prostituição é citado por Green (2000), que vê nesta uma solução para os jovens efeminados na São Paulo da década de 30 ( $p$ 168) e por Barbosa da Silva (2005, p 123-4) que observa a perda do apoio familiar

\footnotetext{
24 A crítica de travestis a respeito de dois homens "masculinos" estarem envolvidos amorosa ou sexualmente é também observada por Kulick (1998, p 126) e Silva (1993, p 42).

${ }^{25}$ Essa associação é reconhecida por todos os estudos sobre travestis já citados.
} 
como fator responsável por este recurso entre estes mesmos homossexuais na São Paulo da década de 50. Discriminados pela sociedade, inclusive por outros segmentos homossexuais, recorriam a estes expedientes, para este autor, por falta de esperanças de ascensão social (p. 94 e 155) ${ }^{26}$.

Valorizados no mercado sexual por sua juventude, não era difícil para as futuras travestis conseguir seus primeiros clientes. Na atividade de prostituição, acabavam por entrar em contato mais próximo com as travestis "já feitas". Esse contato era descrito por elas com riqueza de detalhes. Correspondia à porta de entrada para um novo universo:

V. referiu que se lembra de forma muito clara do momento em que chegou à [capital de estado nordestino]. Disse, retomando uma cara de espanto: "Quando eu vi aquelas bichas, com aqueles bundão, aqueles peitão, eu disse para mim mesma - é isso que eu quero ser” ${ }^{27}$.

Essa "mudança de mundos" parece corresponder de forma bastante próxima à descrição da alternação, proposto por Berger e Luckmann (1966). Esta é definida como um processo onde há uma transformação significativa da realidade subjetiva, exigindo para isso processos de re-socialização.

Para os autores referidos, uma das condições sociais importantes para a alternação refere-se à "possibilidade de dispor de uma estrutura efetiva de plausibilidade, isto é, de uma base social que sirva de "laboratório da transformação" (p. 208). Intrínseca a essa estrutura está a forte identificação afetiva como os demais integrantes da mesma e "uma intensa concentração significante dentro do grupo que corporifica a estrutura de plausibilidade" (p. 209).

Tais elementos estavam certamente presentes na realidade descrita pelas travestis pesquisadas. Estas só se tornavam travestis de fato quando entravam no universo habitado por outras. Embora existissem neste outros atores sociais

\footnotetext{
${ }^{26}$ Há também razões, desenvolvidas no capítulo sobre trabalho, que estão ligadas ao fato da prostituição lhes proporcionar, além de dinheiro, um campo de experiências prazerosas, especialmente ligado ao fato de se sentirem desejadas por homens, que, desta forma, lhes conferem um status de mulher.

${ }^{27}$ Uma travesti entrevistada por Benedetti (2000) faz um relato muito semelhante: "Quando eu vi ela com aquele peito maravilhoso, eu pensei 'é assim que eu vou ser !" (p 96)
} 
importantes, como veremos mais adiante, é principalmente pela relação das travestis umas com as outras que este universo passava a adquirir determinados contornos. Como mostra Weeks (2000), o surgimento de uma identidade que se coloca contra as normas heterossexuais de nossa cultura pressupõe "a possibilidade de algum tipo de espaço social e apoio social ou rede que dê sentido às necessidades individuais" ( $p$ 69). Tal processo corresponde a um dos estágios característicos de formação do que o mesmo autor chama de "identidade pessoal estigmatizada" - denominado estabilização - que pressupõe, pela pessoa, "a completa aceitação de seus sentimentos e estilo de vida, como por exemplo, através do envolvimento numa subcultura que seja capaz de dar apoio a pessoas com a mesma inclinação" ( $p$ 72)

Um dos elementos a serem destacados nesse sentido é a atitude de complacência e cuidado que as travestis tinham, grande parte das vezes, em relação às "novatas", não obstante o risco que estas apresentam às já "feitas" ${ }^{28}$, uma vez que a juventude é, como vimos, extremamente valorizada no mundo da prostituição. Presenciei muitas ocasiões onde esta atitude se manifestou nos encontros:

F. trouxe uma colega no grupo. Perguntaram sua idade: 16 anos. Embora vestida com roupas femininas, ainda não tomava hormônio nem tinha injetado silicone. Imediatamente a novata virou o centro das atenções. Todas queriam dar conselhos a ela em relação às transformações corporais, principalmente incentivando-a a começar logo a tomar hormônios, pois assim o hormônio feminino inibiria o desenvolvimento de pêlos e de formas masculinas. Pensei neste instante que imaginavam para ela um futuro de "deusa"

Esta disposição de ajuda às "novatas" certamente facilitava o ingresso das futuras travestis no universo das "feitas". Essa ajuda materializava-se, muitas vezes, na figura da "madrinha", que tinha uma importância grande entre as travestis estudadas. Correspondia à travesti que inseria outra mais nova na cidade grande, auxiliando-a nos "truques" da profissão e na transformação corporal. Embora não seja impossível a existência de algum interesse financeiro, de participação nos lucros do trabalho da jovem travesti, o interesse maior da madrinha parecia ser o de retribuição: o de ajudar

\footnotetext{
28 O termo "feita" era utilizado no Grupo para designar a travesti que já estava inserida na nova realidade, tendo inclusive passado pelas transformações corpóreas que acompanham tal processo.
} 
alguém como foi um dia ajudada. Nesse caso era comum uma postura maternal, de fazer a "cria" melhor que a "criadora" 29.

Outra figura importante do universo das travestis estudadas era a da "cafetina". Diferentemente da conotação que o termo tem na prostituição feminina, a "cafetina" aqui é uma travesti mais velha, que mantém um espécie de pensão, quase sempre exclusiva para travestis. Enquanto algumas moravam junto com outras, dividindo as despesas e outras com seus "maridos", uma parte considerável das travestis investigadas viviam nessas pensões, administradas por "cafetinas". Essa modalidade de moradia era mais comum entre as mais jovens e isso parecia se dar por dois motivos principais: o fato destas geralmente terem uma renda maior, o que possibilitava maior dispêndio financeiro, e o de isso garantir uma inserção menos perigosa nos pontos de prostituição, na medida em que as "cafetinas" eram figuras respeitadas, devido à idade e/ou à força empregada. As moradoras das pensões geralmente ficavam referidas pelo nome da "cafetina", como no frequente termo "as meninas da J.", por exemplo. Benedetti (2000, p 28) cita a pensão da cafetina como um lugar importante de sociabilidade e aprendizado do universo travesti.

Em sua relação com as "cafetinas" e as demais moradoras, as travestis buscavam muitas vezes a reprodução dos relacionamentos familiares. A exemplo da figura da "madrinha", a "cafetina" parecia ser investida de um lugar maternal, o que algumas vezes gerava profundas decepções entre elas, quando passavam a ser pressionadas nos momentos em que não conseguiam pagar as diárias, evidenciando um interesse apenas financeiro por parte das "cafetinas". Algumas chegavam a aplicar golpes nas moradoras:

P. e A. chegaram visivelmente chateadas. P. contou que a "cafetina" com quem moravam tinha ido embora de repente, levando consigo o dinheiro que elas haviam pedido para guardar. Valores que me impressionaram por serem elevados: $\mathrm{R} \$ 30.000$, no caso de P. e $\mathrm{R} \$$ 10.000, no de A.. Estranhei que tivessem corrido o risco de se deixar tamanha quantia nas mãos da "cafetina". Mais tarde, A. disse: "O pior não foi o dinheiro, o pior foi ela levar também as minhas bonecas" - e começou a chorar.

\footnotetext{
29 A relação com a "madrinha" é também citada por Benedetti (2000, p 99), Ferreira (2003, p.119) e Pelúcio (2005b)
} 
O sofrimento, no caso citado, parecia ser não apenas pela perda financeira, mas também pela perda dos vínculos afetivos próprios a essa família substituta. Tal busca por um grupo que substituísse a família não era exclusiva das travestis do Grupo, mas parece comum a grupos marginalizados socialmente. Walkowitz (1990), por exemplo, descreve o bordel nas grandes cidades européias do século XIX como substitutos da família e como sistema de apoio para mulheres vindas da zona rural ou de camadas populares urbanas, rejeitadas pela família de origem.

Outra modalidade de relacionamento importante entre as travestis estudadas era a de amizade. Estas relações, às vezes bastante intensas, se estabeleciam em função do local de moradia, como no caso das que moravam na mesma casa, apartamento ou pensão, e em função do local de trabalho, como no caso das que trabalhavam em locais próximos. A função de proteção mútua era evidente no caso do trabalho exercido, como veremos no capítulo sobre prostituição, e na evitação da discriminação, uma vez que as ofensas usualmente dirigidas às travestis individualmente tornavam-se perigosas se emitidas para um grupo. Mas certamente havia também trocas afetivas nessas amizades que são relevantes para se entender sua dinâmica de funcionamento. Essa modalidade de relação envolvia muitas vezes o cuidado da amiga travesti doente $^{30}$, mas não era de forma alguma isenta de conflitos, em um grupo marcado fortemente pela competitividade, como veremos mais adiante ${ }^{31}$.

\footnotetext{
${ }^{30}$ Hélio Silva (1993) cita também tal cuidado, que sugere ser substitutivo da relação mãe/filha (p 55).

${ }^{31}$ A busca pela turma de amigos como um substituto da família é citada como algo frequente por Green (2000), em relação do universo homoerótico brasileiro da segunda metade do século XX (p. 290). Entre as travestis estudadas, contudo, a busca por um relacionamento paradigmaticamente familiar não era total. Em relação às que moravam juntas dividindo despesas, tal condição parecia um tanto quanto instável, uma vez que as moradoras continuamente se mudavam de uma casa ou apartamento para outro. Perlongher (1987a, p. 188-194) relaciona o mundo dos michês e de outros personagens da prostituição masculina em São Paulo com o conceito de nomadismo, proposto por Deleuze e Guattari em "Mil Platôs". No nomadismo o modelo de grupalização é o bando, que tem como algumas de suas características a ausência da consolidação de um poder estável, a transitoriedade e a rotatividade, o que faz com que seus integrantes se dissolvam e se reagrupem novamente. Na sedentariedade, por outro lado, ordem dominante na sociedade capitalista e que tem a família como modelo por excelência, os indivíduos são capturados espacial e identitariamente em organizações sociais mais definidas. Estes dois modelos de sociabilidade coexistiam de várias formas no universo dos michês estudados por Perlongher (1987a), o que fazia com que estes constantemente oscilassem entre os mesmos. Tal proposta de análise é adequada também, em meu entender, para explicar a realidade observada por mim entre as travestis de baixa renda estudadas.
} 
A entrada da travesti nesse novo mundo implicava no correspondente afastamento do antigo mundo, algo necessário ao processo de ressocialização descrito por Berger e Luckmann (1966). Isso era bem evidente no caso das travestis pesquisadas, que viviam de fato de forma bastante segregada, convivendo apenas com outros personagens desse universo marginal. Muitas haviam perdido totalmente 0 contato com sua família de origem. Outras mantinham contato por telefone ou carta, com visitas ocasionais. A retomada do contato com a família parecia se tornar possível, algumas vezes, em função da ajuda financeira que passavam a prestar à família - o que as fazia pensar que o apoio familiar era "comprado"32.

\footnotetext{
P. voltou de viagem a sua cidade natal [interior do Nordeste]. Contou que fazia cinco anos que não ia e que resolveu "enfrentar". Temia muito pela reação de seu pai, que ainda não a tinha visto depois da transformação corpórea. Conta que chegou "pisando firme' e que por isso foi respeitada. Nesse momento V. e L comentaram que as famílias só queriam saber de "aqué" [dinheiro], sugerindo que P. só teria sido aceita por ter ajudado financeiramente sua família, mas ela não respondeu à provocação.
}

Outra característica da alternação apontada pelos autores citados é a da reorganização do aparelho de conversa. A nova realidade subjetiva se transforma e se mantém pela permanente conversação com os integrantes da nova realidade objetiva. Implícita nesse processo está a evitação sistemática de pessoas e idéias discrepantes das novas definições de realidade ( $p$ 211). Tal fato era evidenciado no universo das travestis estudadas pela forma como se dava a utilização da linguagem entre elas.

Uma das primeiras dificuldades pelas quais passam aqueles que começam a interagir com travestis é a do entendimento de sua linguagem. Há uma grande utilização de termos que são desconhecidos pela grande maioria da população. Em alguns locais no Brasil, tal linguagem chega inclusive a receber um nome ${ }^{33}$. A utilização de termos específicos serve como instrumento de defesa em relação ao restante da

\footnotetext{
32 A "compra" do apoio familiar entre as travestis de Salvador é citada por Kulick (1998, p 181). Green (2000) sugere ser algo existente no universo homoerótico como um todo (p. 377).

${ }_{33}$ Por exemplo, bate-bate, em Porto Alegre (Florentino, 1998, p. 71-80). "Pajubá” é o nome pelo qual tal linguagem é conhecida nacionalmente. Ao comparar os termos utilizados pelas travestis com os descritos no "Dicionário antológico da cultura afro-brasileira", de Fonseca Jr (1995) observei uma grande concordância nos sentidos a eles atribuídos pelas travestis e pelo dicionário.
} 
sociedade, uma vez que permite uma comunicação efetiva sem que "quem não é do ramo" possa entender ${ }^{34}$.

A linguagem utilizada pelas travestis é permeada por termos oriundos de dialetos africanos, como o iorubá e o nagô. Como mostra Birman (1995, p. 53), nos cultos afrobrasileiros, a utilização de tais dialetos se relaciona à origem étnica dos cultos, mas também é uma manifestação de pertencimento a um grupo seleto e uma proteção em relação aos que estão de fora das fronteiras definidas por estes cultos.

Em seu estudo sobre a relação entre a homossexualidade e os cultos afrobrasileiros, Fry (1982) observa que a literatura existente sobre tal tema sugere que há uma forte associação entre ambos, uma vez que "as casas de culto representam um nicho social no qual os 'homossexuais' podem expressar sua 'feminilidade' através de sua associação com os grupos predominantemente femininos e através da possessão de espíritos femininos" (p. 56). A essas análises, acrescenta que tais cultos atraem indivíduos com preferência homoerótica pelo próprio caráter de desvio atribuído tanto ao culto quanto à homossexualidade. O terreiro, assim, aparece como um lugar de continência para esta.

É possível supor, feitas estas considerações, que a associação histórica entre cultos afro-brasileiros e homossexualidade possibilitou a incorporação, por parte das travestis, de termos presentes nos dialetos utilizados nestes cultos. Tal possibilidade explicaria também a razão de outros segmentos homossexuais utilizarem alguns destes termos. Isso não implica que as travestis de fato frequentem tais cultos em usa maioria. Tal referência entre as travestis do Grupo existia, mas não era comum. Kulick (1998) observa que mesmo em Salvador, local em que fez pesquisa de campo e que tem

\footnotetext{
34. A utilização da linguagem travesti no Grupo era comum, às vezes como meio de evitar meu entendimento do que estava sendo dito. Depois de algum tempo, conseguia “traduzir" a grande maioria dos termos, o que não evitava que eu deixasse de entender algumas travestis que falavam rapidamente, utilizando alguns dos verbos com múltiplos significados típicos dessa linguagem. Uma vez que esta linguagem tem uma função de proteção para as travestis, penso ser importante, por motivos éticos, respeitar esta função, o que significa não descrever e "traduzir" os termos utilizados, a não ser em alguns poucos casos, onde tal descrição seja fundamental para este estudo. Pelo mesmo motivo, evito a citação aqui de alguns "dicionários” já elaborados sobre a linguagem das travestis.
} 
expressiva presença de cultos afro-brasileiros, eram raras as travestis que os frequentavam ${ }^{35}$.

\section{O "marido" e a "mulher submissa"}

Ao considerarmos o tornar-se travesti como um processo de ressocialização, fica claro que a identidade de "viado" ou "bicha" era também bastante modificada, pela incorporação de elementos relativos a outras identidades. Pelo fato da transformação do corpo e gênero próprios ocorrer pela tentativa de feminização dos mesmos, é importante que possamos compreender as concepções de feminilidade presentes entre as travestis estudadas. Para tanto, é necessária uma descrição e análise prévia das diferentes modalidades de relacionamento afetivo e sexual que elas estabeleciam, em diferentes contextos interacionais.

Os parceiros com quem as travestis do Grupo estabeleciam relações amorosas e/ou sexuais eram por elas classificados basicamente em três tipos: os clientes, os "maridos" e os "vícios". Os primeiros, parceiros que pagavam por algum tipo de prática sexual, serão descritos no capítulo sobre prostituição. Os "maridos" correspondiam às pessoas com quem tinham relacionamentos fixos e os "vícios" aos indivíduos com os quais mantinham relações sexuais de forma ocasional. Podia-se perceber um padrão bastante diferenciado entre as relações que estabeleciam com os "maridos" e os "vícios", o que faz necessária sua descrição de forma detalhada.

As relações estabelecidas entre as travestis e seus "maridos" eram inspiradas nas relações que se estabelecem comumente entre homens e mulheres heterossexuais, no que diz respeito ao relacionamento sexual (daí o termo "marido", ser coerente com a representação que se faz do parceiro nesse contexto). Presumia-se que o "marido" deveria fazer o papel correspondente ao do "macho" da relação sexual heterossexual: este podia penetrar analmente sua companheira, tocá-la em suas partes

\footnotetext{
${ }_{35} \mathrm{O}$ único estudo que descreve como frequente prática de rituais afro-brasileiros entre travestis é o de Vale (2000), realizado em Fortaleza (p. 113).
} 
femininas, oferecer seu pênis para felação, mas jamais tocar em seu pênis ou ter o ânus penetrado ou tocado por ela. Dentro deste contexto, a relação com o "marido" parecia oferecer à travesti um lugar imaginário de mulher. O "marido", ou o homem candidato à "marido", parecia ser tão mais valorizado quanto mais se aproximava do estereótipo do "macho" tradicional. Atributos como agressividade e interesse por mulheres e posse de pênis avantajado eram bem-vindos ${ }^{36}$. Consequência disso era a preferência por 'maridos' com alguma inserção no mundo do crime ${ }^{37}$.

O interesse do "marido" por mulheres atestava sua masculinidade, compensando um possível sentimento de ciúmes. Por isso tolerava-se que o mesmo tivesse relacionamento concomitante com mulheres. Havia inclusive "maridos" de travestis que o eram também no sentido clássico, isto é, eram casados heterossexualmente e viviam com suas companheiras mulheres ${ }^{38}$. Aqui aparecia um primeiro ponto de tensão nesse relacionamento, que era o da possível perda desta masculinidade. O receio referia-se à possibilidade deste desejar um relacionamento onde se colocasse de forma passiva com sua companheira travesti ou então, mais grave ainda, com outro homem ou travesti.

Em meio a uma discussão sobre relacionamentos amorosos, V. provocou aquelas que tinham marido no Grupo: "Vocês acham que se eles fossem homens mesmo eles estariam com vocês? Eles iam preferir uma mulher, não um viado"

Talvez uma das decepções mais fortes entre elas fosse a de descobrir que seu "marido" se relacionou sexualmente de forma passiva com outra. Por isso, elas às vezes buscavam seduzir um "marido" exatamente como forma de vingança direcionada

\footnotetext{
${ }^{36}$ Benedetti (2000, p 118-121) considera que tal relação está marcada pela necessidade das travestis se sentirem desejadas como mulher: a relação com um macho "confere e afirma o gênero feminino nas travestis" ( $p$ 118).A relação entre a travesti e seu marido como uma relação entre personagens estereotipadamente masculinos e femininos é também descrita por Kulick (1998, 124-5) e por Pelúcio (2005b)

${ }^{37}$ A relação amorosa das travestis com bandidos, também citada por Benedetti (2000, p 121), será objeto de consideração no último capítulo.

${ }^{38}$ Embora muitas vezes envolvesse moradia conjunta, as travestis às vezes chamavam de "maridos" companheiros que viviam em casas separadas.
} 
a alguma travesti, situação que tinha consequências imprevisíveis, às vezes envolvendo embates mortais.

Um dos campos de tensão na relação das travestis do Grupo com seus "maridos" era o da divisão de trabalho e renda no casal. Embora alguns "maridos" trabalhassem e ajudassem nos gastos do casal, era quase sempre elas que os sustentavam financeiramente, ficando numa posição próxima ao que popularmente se conhece como "mulher de malandro" ${ }^{39}$. Essa dinâmica era muito criticada por outras travestis, que se recusavam a manter tal tipo de relacionamento exatamente por considerá-lo uma exploração sob o aspecto econômico ${ }^{40}$ :

Em uma grande discussão sobre as vantagens de se ter ou não "marido", L. foi bastante enfática: "Eu, hem?! Ficar sustentado malandro? Eu, não !".

Nesta relação permeada pela idéia de passividade, partia-se do pressuposto de que a travesti, assim como a mulher, deveria aceitar de forma submissa os desejos e as ordens do "marido" e satisfazê-lo sexualmente. A representação da mulher submissa presente nessa relação era, muitas vezes, exagerada, aparecendo de forma nítida no sofrimento cultivado na relação. Por diversas vezes pude presenciar conversas de travestis contando uma às outras explosões de agressividade de seus "maridos", de forma bastante prazerosa:

\footnotetext{
39 O termo "mulher de malandro" foi popularizado por um samba de Heitor dos Prazeres, gravado por Francisco Alves, na década de 30, cuja letra afirmava: "Mulher de malandro sabe ser / Carinhosa de verdade / Ela vive com tanto prazer / Quanto mais apanha a ele tem amizade! / (Longe dele tem saudade) / Ela briga com o malandro / Enraivecida manda ele andar / Ele se aborrece e desaparece / Ela sente saudade, vai procurar / (Há um ditado muito certo: pancada de amor não dói) / Muitas vezes ela chora / Mas não despreza o amor que tem / Sempre apanhando e se lastimando / Perto do malandro se sente bem / (É, meu bem, o malandro também tem seu valor).

40 A referência ao frequente sustento financeiro do marido e os conflitos daí advindos são também feitas por Kulick (1998, p. 107), Benedetti (2000, p 122), Silva (1993, p 77), Ferreira (2003, p. 60) e Pelúcio $(2005 \mathrm{~b})$
} 
S. falou por um bom tempo de como seu marido era agressivo, tinha ciúmes de outros homens e clientes. Nitidamente estava 'dando um close'41 para as outras. Em um certo momento, falou para todas: “Ah, como é sofrido ser mulher!”

Tal agressividade evidenciaria não somente a masculinidade do "marido" como também a feminilidade da travesti agredida. Algumas falavam com nítido prazer do sofrimento que experimentavam quando apaixonadas, em um aparente deleite. A paixão e a submissão pareciam desejáveis, da mesma forma que a passividade, por conferir-lhes um lugar feminino ${ }^{42}$.

A busca por uma feminilidade associada à passividade, submissão e paixão desenfreada, contudo, talvez não explique totalmente tal relação. Silva (1993, p 73), por exemplo, considera que um certo elogio da agressividade viril é compatível com os maus-tratos aos quais as travestis estão acostumadas, ou seja, podemos pensar que em tal relação se configura uma forma de afeto - misturada à violência - que teriam aprendido no decorrer de sua vida. Podemos perceber uma semelhança desta relação, também, com a relação clássica da prostituta com seu cafetão. Ao analisar tal relação na São Paulo do início do século XX, Rago (1991) observa que nesta a prostituta podia ser reconhecida como um indivíduo, ao contrário do que ocorria na estabelecida com o cliente, para quem "representava um órgão e uma performance" (p. 279). O apanhar e bater próprios à relação com o cafetão constituía-se como uma troca afetiva ausente na interação com o freguês. Consideramos que tal análise é apropriada para explicar também a relação estabelecida entre as travestis pesquisadas e seus "maridos".

A analogia da relação entre a travesti e seu "marido", com aquela estabelecida entre a prostituta e seu "cafetão", porém, mostra que o "marido" fica, também, paradoxalmente, em uma posição tradicionalmente feminina, uma vez que, como mostra Parker (1992), na relação da prostituta com seu cafetão ocorre "a dependência econômica dele em relação a ela, a aceitação o dinheiro que ela recebe e a concordância em que ela mantenha relações sexuais com outros homens" ( $p$ 85).

\footnotetext{
${ }^{41} \mathrm{O}$ termo se refere aos atos de provocação pelos quais uma travesti tenta demonstrar que é superior à outra. É possível que tenha origem na música feita por Erasmo Carlos para a conhecida travesti Roberta Close, cujo refrão diz "dá um close nela”.

${ }_{42}$ Essa associação é também proposta por Kulick (1998, p 93 e 107) e Benedetti ( 2000, p 121 )
} 
Um outro elemento que mostrava as contradições presentes na incorporação da identidade de "mulher submissa", na relação das travestis com seus "maridos", era a recusa aos trabalhos domésticos por parte de algumas delas. Se a paixão e a sexualidade Ihes conferia um lugar imaginário de mulher, o trabalho equivalente ao da "dona-de-casa" não ${ }^{43}$ :

[Em uma conversa sobre as vantagens de se alugar uma casa ou apartamento com outras travestis] L falou que as muitas eram "preguiçosas" e não queriam "saber de lavar um prato ou uma panela" e por isso preferiam ficar morando com cafetina - pareciam "um bando de marmanjo”. A reação de várias - uma risadinha discreta - pareceu mostrar uma concordância em relação a L.

Uma consequência do relacionamento com os "maridos", tal como ele era estruturado hegemonicamente entre as travestis do Grupo, era a ausência da possibilidade de ejaculação da travesti no relacionamento sexual. Ter ejaculação ou mesmo ter ereção significava se colocar como "homem" na relação, saindo do lugar imaginário de mulher ${ }^{44}$.

V. [ausente do Grupo por alguns meses] retornou com o corpo visivelmente modificado, tendo principalmente os seios aumentados. Ao ser questionada por mim se havia colocado silicone, ela respondeu, orgulhosa e realçando o busto, que não, que tal mudança era resultado de um tratamento hormonal e que estava tomando "duas injeções por dia”. Um tanto preocupado com sua saúde, quis saber os motivos dela estar fazendo uso de tal quantidade de hormônios, mas ela mudou de assunto, dando a entender que tal ato teria algo a ver com seu novo "marido". Pensei que talvez houvesse um desejo de sua parte de se mostrar a ele com um corpo mais feminino. Neste instante, L. entrou na conversa e disse que havia deixado de tomar hormônios recentemente por estar tendo dificuldade de ereção no relacionamento sexual com seus clientes. Seguiu-se uma discussão com outras integrantes do grupo a respeito da relação entre uso de hormônios femininos e dificuldade de ereção e V. se exasperou durante ela, afirmando que se utilizava de hormônios femininos justamente por

\footnotetext{
${ }^{43}$ Silva (1993, p 94) mostra também a crítica de algumas travestis àquelas que não faziam o trabalho doméstico.

${ }^{44}$ Kulick (1998, p 57 e 133) observa de forma semelhante que só com clientes a travesti poderia ter prazer, não com seus "maridos". É importante relativizar, contudo, a equivalência do prazer com orgasmo: o fato de não terem ejaculação não significa que a relação não fosse sexualmente prazerosa (tal observação me foi sugerida por Marília Pinto Carvalho, no Exame de Qualificação)
} 
sua propriedade de evitar a ereção, dizendo achar "um absurdo" ter ereção quando em relação íntima com seu "marido”. L. [cujo "marido” estava presente na reunião] disse a V. que para ela “isso não tinha nada a ver" e que ela achava que se podia perfeitamente ter ereção e orgasmo no relacionamento sexual com o "marido", desde que não fosse de forma ativa, se masturbando durante uma relação anal passiva, por exemplo.

Interessante notar a partir desse relato que, embora houvesse uma visão predominante entre elas a respeito do que era pertinente à travesti a ao "marido" em uma relação sexual, ou, imaginariamente, à mulher e ao homem, esta visão não era única e estava sujeita a abalos e mudanças. V., por exemplo, supunha que no lugar feminino passivo em que se colocava não cabia a possibilidade de se excitar, daí o receio em relação à ereção. No caso de L., o diferencial estabelecido entre ela e o parceiro fixo dizia respeito à iniciativa e controle frente ao ato, que cabia ao último, transparecendo uma idealização do gênero feminino como passivo, porém sexualmente excitável. Em outros momentos pude presenciar travestis manifestarem posições diferentes: algumas referiram se masturbar somente depois da relação sexual, na ausência do "marido", enquanto outras disseram gostar de ser também "ativas" na relação com seus "maridos", buscando a penetração ${ }^{45}$.

Paralelamente ao modelo travesti/"marido" existiam entre as travestis estudadas outras modalidades de relacionamentos fixos, minoritárias, que fugiam das características deste modelo. Exatamente por fugir do padrão considerado aceitável pelas demais, tais relacionamentos eram pouco comentados nos encontros. Uma delas referia-se ao vínculo amoroso com michês, também citado por Perlongher (1987a, $p$ 236), que envolvia o compartilhar das despesas domésticas e que implicava na aceitação do michê ter relações "passivas" com os clientes, o que o diferenciava do "marido" tradicional. Outra modalidade existente era o do relacionamento amoroso entre

\footnotetext{
${ }_{45} \mathrm{O}$ reconhecimento de que as relações hegemônicas entre as travestis do Grupo e seus “ maridos” não eram absolutas é concordante com outras pesquisas sobre travestis no Brasil, como as de Marcelo Oliveira (1997, p 76) e de Florentino (1998, p. 154). Kulick (1998) ao contrário, defende o modelo predominante como total, afirmando que travestis jamais tolerariam penetrar sexualmente um "marido" (p 107).
} 
duas travestis, algo muito criticados pela maior parte delas, que chamavam tais travestis de "bichas lésbicas"

S. veio pela segunda vez no Grupo. Disseram-me que ela era "bicha lésbica" e que tinha um "caso" com F. Durante o encontro tal assunto veio à tona, e S. defendeu seu relacionamento: "eu gosto de bicha, sim, qual o problema?". As demais travestis pareceram inconformadas com a situação.

A maioria delas evitava a proximidade dos "maridos" com outras travestis por serem os mesmos intensamente assediados. Mesmo assim pude ter contato com alguns destes "maridos", que às vezes frequentavam os encontros. Geralmente eram bastante jovens, alguns adolescentes e procuravam manter uma postura máscula, na maneira de se sentar e falar. Aparentavam sempre um certo incômodo por estarem participando de um Grupo nomeado como "grupo de travestis". Em mais de uma ocasião, porém, observei que os mesmos se entusiasmavam quando o assunto se direcionava ao consumo de drogas, o que me deu a impressão de serem usuários assíduos. Um "marido", especificamente, me solicitou um encaminhamento para tratamento em virtude de dependência de cocaína, que era adquirida com o dinheiro dos "programas" de sua companheira.

\section{O "vício"}

Se a relação hegemônica das travestis com seus "maridos" tinha suas regras continuamente desafiadas, a relação com os "vícios" exprimia de forma ainda mais complexa o relacionamento delas com o sistema de gêneros existente. O "vício" era geralmente um jovem que atraía a travesti por seus dotes físicos: beleza e, principalmente, pênis grande, bastante valorizado por elas, em virtude de supostamente

\footnotetext{
46 A existência de relacionamentos afetivos entre travestis, muitas vezes de longa duração, é também observada por Benedetti (2000, p 120)
} 
proporcionar maior prazer sexual ${ }^{47}$. Se a regra com os "maridos" era a da passividade, com os "vícios" virtualmente tudo era possível. Aparentemente era nessa modalidade de relação que o prazer sexual se maximizava, em suas várias formas, com a travesti passando a assumir também as posições tidas como "masculinas" no relacionamento sexual e se permitindo a ejaculação e o orgasmo:

Tanto prazer era gerado por este tipo de relacionamento que o mesmo se tornava uma ameaça: a de levar a travesti a se relacionar sexualmente apenas por prazer, deixando o interesse econômico de lado. O próprio termo de referência, "vício" vinha daí, ou seja, algo prazeroso, mas potencialmente destrutivo, se não for controlado $^{48}$. O termo "bicha viciosa" era usado para se referir de forma pejorativa às travestis que frequentemente se relacionavam sexualmente apenas por prazer, o que representava uma ameaça a todas elas: se podiam ter relacionamento sexual grátis, por que os "vícios" iriam pagar por ele?

Entre os "vícios" comuns das travestis do Grupo estavam adolescentes bastante jovens, fato que comentavam com certo cuidado, pelas possíveis implicações legais de tal relacionamento:

L. falou baixinho para mim que seu "vício" principal era por garotos jovens. Rindo, disse que adorava "dar de mamar para eles" [sexo oral passivo], mas que fazia tudo "meio escondido" por medo da polícia [tinha medo de ser acusada por abuso sexual de menores]

Algumas referiam ser constantemente procuradas por estes jovens, alguns "bichinhas", segundo elas, para relações sexuais gratuitas. Em alguns casos, esta procura parecia estar relacionada ao desejo de se aproximar delas, pela admiração que despertavam neles:

\footnotetext{
47 Tal modalidade de relacionamento sexual é citada também por Kulick (1998, p. 29), Pelúcio (2005b), que considera o vício um "meio-termo" entre o cliente e o "marido". Benedetti (2000, p 124), usa o termo "boiação”, que parece ser mais comum na região Sul, para esta relação, mas considera que nelas as travestis são sexualmente "passivas", buscando somente se sentir desejadas (p 126-7), o que difere de minha observação entre as travestis do Grupo

${ }_{48}$ Vale (2000), em um estudo sobre um cinema pornô de Fortaleza, com forte presença de travestis, observa esta mesma preocupação entre as mesmas (p 123)
} 
L. contou que um garoto, morador de uma favela próxima ao local onde faz ponto ficou olhando-a detidamente, ao que ela indagou: “o que foi, menino ?”. O menino pediu para ver seu pênis, ao que ela consentiu, por se tratar de horário de baixo movimento. Deu uma “pegadinha”, segundo ela e perguntou no final: "Tia, posso ser igual a você quando crescer?"

Um elemento interessante a ser destacado nas descrições sexuais das travestis pesquisadas em relação aos vícios, assim como nas estabelecidas com os clientes, era o da grande aceitação das diversas modalidades de práticas sexuais, ao contrário do que ocorria na interação com os "maridos". Welzer-Lang (1994, p 108) observou, entre homens e mulheres que se prostituíam em Lyon, na França, que, enquanto as mulheres construíam um discurso onde diversas práticas sexuais eram negadas, em função da dor e do nojo que diziam provocar ${ }^{49}$, entre transgêneros a aceitação era quase total. Penso que o mesmo acontecia entre as travestis do Grupo, onde pouquíssimas vezes ouvi referências à repulsa frente a determinado tipo de ato sexual, nas relações com vícios ou clientes. Isso só ocorreu, segundo minhas anotações e lembranças, em dois contextos: em relação aos sexo oral com mulheres, clientes muito esporádicas ${ }^{50}$ e no caso de um cliente frequente na "noite", que demandava relações sexuais com travestis na companhia de seu filho, de cerca de 8 anos, o que a maioria recusava.

Se na relação com o "marido" percebemos a "mulher submissa" como um fragmento identitário constituinte de identidade travesti, na relação com os vícios as travestis eram sobretudo "gays". Embora a passividade frente aos atos sexuais ainda fosse um elemento dominante, abria-se espaço para uma flexibilização frente a esses lugares, assumindo-se elementos de uma "identidade gay", que como vimos, começou a se disseminar nas grandes cidades brasileiras a partir da década de 70 , co-existindo e se misturando às identidades "tradicionais" do universo homoerótico e que tem como uma de suas características a recusa às posições fixas do "ativo" e "passivo" no relacionamento sexual.

\footnotetext{
${ }^{49}$ Citado também entre prostitutas cariocas por Gaspar (1985, p 114)

${ }^{50} \mathrm{O}$ mais comum, nestes casos, é que casais procurassem a travesti, solicitando que a mesma mantivesse relacionamento sexual com a mulher. Enquanto o sexo vaginal era tolerado, embora muitas vezes nãodesejado, o sexo oral causava repulsa em algumas, mas não em todas: uma delas afirmou, em um dos encontros, gostar bastante da referida prática.
} 


\section{CORPO}

Uma perspectiva comum nas Ciências Humanas tem sido a de tratar o corpo como um elemento variável, sujeito a uma história, e não como um elemento constante, forma como é encarado tipicamente nas Ciências Biológicas (Nicholson, 2000, p.14). Em sua defesa da genealogia niestzschiana, que implica na negação da busca por origens essenciais nas pesquisas e em uma proposta de compreensão a partir de uma radical historicidade, Foucault (1979) considera o corpo como "inteiramente marcado de história" ( $p$ 22). Aceitar isso pressupõe que qualquer entendimento sobre o corpo deva se basear em uma análise das condições históricas às quais o mesmo é submetido, uma vez que não há como se falar de um corpo "natural", puramente biológico, que esteja fora das relações de poder.

Para Foucault (1975), a própria noção de indivíduo é produzida pelo que denomina "poder disciplinar". Seu corpo, a partir do século XVIII, no Ocidente, se transformou no alvo principal das estratégias de controle sobre estes indivíduos, por permitir sua localização no espaço. Neste momento histórico, o corpo passou a ser objeto de análise, através da anatomia, revestindo-se seu funcionamento de inteligibilidade. Por garantir a visibilidade dos indivíduos, se tornou também objeto de uma série de processos e regulamentos com a finalidade de controle e correção de suas operações. O objetivo das tecnologias disciplinares, para o autor, foi o de garantir a utilidade e docilidade desses corpos.

Os discursos médicos exercem forte influência sobre a sociedade contemporânea, se impondo como "o" saber sobre o corpo, em uma posição de superioridade sobre os saberes alternativos. Tributário do poder disciplinar, o saber médico tende a considerar os corpos como elementos estáveis, desconsiderando o fato de que "construímos nossos corpos, incorporando a experiência em nossa carne mesma " (Fausto-Sterling, 2001, p 59). A alternativa a essa visão é a de considerar o 
discurso médico como "um" saber sobre o corpo, a partir de uma abordagem crítica, sem desconsiderar o fato de que tal saber se coloca de forma hegemônica para diversos segmentos sociais.

A medicina que se desenvolve a partir da era moderna tem como uma de suas características principais a tendência a pensar os corpos como matéria, à semelhança dos objetos inanimados, tornando o homem cada vez mais coisificado, como mostra Nicholson (2000, p. 15). Essa ênfase no materialismo das ciências médicas não significou, contudo, apenas uma mudança em relação à forma de se entender o corpo, uma vez que se passou também a procurar neste explicações para as diferenças que até então eram justificadas por argumentos derivados da religião ou da filosofia. Para a mesma autora, o corpo progressivamente assumiu um lugar central na definição do eu (p. 16), o que é evidente nas tendências dentro das ciências médicas que se pautam pelo determinismo biológico. Um dos exemplos mais citados por historiadores para mostrar a forma como o corpo foi utilizado para justificar as diferenças entre grupos humanos é o surgimento da idéia de raça, no século XVIII. Nicholson (2000), revisando o estudo de vários estudiosos do assunto, mostra que, anteriormente a esse período, as diferenças que os africanos tinham em relação aos europeus eram explicadas não somente pelas diferenças físicas, mas principalmente pela diferença de costumes e pelo fato de serem pagãos. A partir do conceito de raça, o corpo se tornou não apenas um dos elementos de diferenciação entre europeus e africanos, mas a causa de todas as diferenças existentes ( $p$ 17-8).

Um processo semelhante se deu em relação à diferenciação entre homens e mulheres. Enquanto as diferenças entre ambos eram justificadas na Filosofia por motivos metafísicos (por exemplo, em Aristóteles, onde a mulher era a causa material e o homem a causa eficiente) e no Cristianismo por motivos religiosos (utilizando-se a Bíblia como testemunha), na medicina moderna passaram a ser explicadas fundamentalmente a partir das diferenças corporais entre eles. Para Nicholson (2000), a distinção masculino/feminina se tornou objetificada nos corpos por uma metafísica materialista ( $p$ 18). Laqueur (1992) vai se referir a este processo como o surgimento de um modelo bissexuado do corpo. 
As obras sobre a história da anatomia sexual escritas pelo historiador Thomas Laqueur $(1987,1992)$ tiveram um grande impacto sobre os estudos de gênero e sexualidade desde então. Isto se deve ao fato dos estudos antropológicos a respeito de outras culturas serem a principal fonte até aquele momento para o questionamento da vinculação entre biologia e as diferenças percebidas entre homens e mulheres. A antropologia serviu como principal instrumento para a crítica à concepção essencialista da sexualidade, ou seja, à idéia de que o sexo é uma força que antecede a vida social, sendo algo imutável, a-histórico (Rubin, 1999). Como resposta a esse tipo de visão surgiram as teorias que passaram a ser agrupadas sob o nome de "construcionismo social", ou seja, teorias que enfatizavam que a divisão de gênero é uma construção cultural que surge para dar conta das diferenças sexuais binárias. Alguns autores, porém, passaram a questionar também essas teorias, postulando uma forma mais radical de "construcionismo social", onde o corpo passa a ser entendido também como algo histórico, e não como algo biológico, invariante, sobre o qual a cultura se instaura (Moore, 1994). Foram justamente as obras de Laqueur que vieram a fortalecer esse tipo de visão dentro das Ciências Sociais, quando o mesmo questiona a idéia da obviedade do dimorfismo sexual, propondo que tal concepção é bastante recente dentro das sociedades ocidentais. O impacto de suas obras deveu-se principalmente ao fato de tais discussões terem se movido do terreno referente a outras sociedades, objetos tradicionais dos estudos antropológicos, para o das próprias sociedades ocidentais.

A tese central de Laqueur (1992) é a de que a concepção atual da existência de um dimorfismo sexual entre homens e mulheres tem suas raízes no século XVIII. Enquanto na literatura médica anterior, dos gregos até meados do século XVII, o corpo feminino era considerado uma versão do corpo masculino, tendo em relação ao mesmo uma proximidade maior e diferenças sutis, a visão do corpo feminino a partir do século XVIII é a de algo radicalmente diferenciado em relação ao corpo masculino, em muitos sentidos oposto ao mesmo.

Laqueur (1992) fornece inúmeras evidências que apontam a existência de uma diferença de grau e não de tipo entre homens e mulheres na Medicina até o século XVII. A vagina, por exemplo, era tida como uma versão de um pênis menos desenvolvido e interiorizado. A menstruação, por sua vez, era entendida não como algo 
próprio às mulheres, mas como uma tendência dos corpos humanos ao sangramento, que tinha a função de livrá-los do excesso de nutrientes. A produção de sêmen, para a medicina grega, era algo presente em homens e mulheres. Havia, assim, um modelo de hierarquia entre homens e mulheres que não obedecia a idéia de que a diferença sexual era causadora da superioridade masculina. As "descobertas" médicas, longe de apontar a diferença entre homens e mulheres, se acomodavam sempre à idéia de que ambos tinham corpos semelhantes. O corpo feminino era entendido como uma versão inferior do masculino, havendo uma paridade entre órgãos como testículos e ovários, escroto e útero, prepúcio e lábios da vagina, glande e clitóris. Mesmo o nome utilizado era o mesmo para cada um desses pares citados, sendo indiferente seu uso para se referir aos órgãos do homem ou da mulher. O elenco de homologias entre o homem e a mulher citadas pelo autor é extenso: acreditou-se durante muito tempo na medicina ocidental que só com a liberação de um tipo de esperma pela mulher, durante o orgasmo feminino, é que poderia haver fecundação.

Este panorama começa a mudar substancialmente, porém, em meados do século XVIII, com o surgimento do que Laqueur (1992) denominou modelo de dois sexos (twosex model) dentro da medicina. As razões que propõe para tal surgimento são o declínio do domínio religioso - e consequentemente da Bíblia como fonte de justificativa para as diferenças entre homens e mulheres - e das explicações aristotélicas, com a conseqüente necessidade de encontrar novas formas de se explicar tais diferenças, mantendo a hierarquia homem/mulher. O domínio privilegiado que passou a servir de suporte para as novas legitimações das diferenças é justamente aquele que já se tornava o alvo principal das estratégias de controle naquele momento: o corpo.

A partir do século XVIII começou a haver uma verdadeira "corrida" para se encontrar as máximas diferenças nos corpos masculino e feminino: havia que se encontrar nestes tudo o que servisse para justificá-las. A anatomia passou a buscar nos ossos músculos, nervos e veias dos seres humanos elementos que mostrassem que os dois sexos eram completamente diferenciados (Schiebinger, 1987). O esqueleto passou a ser considerado uma prova da diferença primordial entre homens e mulheres (e da superioridade masculina), uma vez que a pélvis mais alargada provaria o destino das mulheres à maternidade e o menor tamanho do crânio sua inferioridade intelectual. Da 
mesma forma, toda a atual descrição da anatomia sexual feminina passou a ser progressivamente formulada a partir daquele momento histórico, estabelecendo-se de forma marcante as concepções de dimorfismo sexual que perduram até hoje ${ }^{1}$.

Fica claro, uma vez expostas estas idéias, que há na posição de Laqueur uma tendência exatamente oposta ao determinismo biológico citado anteriormente: ao contrário da noção de que o sexo determina o gênero, suas idéias nos levam a pensar que o sistema de gêneros, tal como construído em uma dada sociedade, é que vai determinar a forma como a mesma vai interpretar o sexo, mesmo em sua dimensão "biológica". O sexo, exatamente em sua dimensão corporal, é um produto social, posição esta que é semelhante àquela defendida por teóricas importantes, como Moore (1994), Rubin (1999) e Nicholson (2000).

A consequência deste processo de diferenciação histórica progressiva entre os corpos masculino e feminino é a da construção de identidades sexuais masculina e feminina distintas e enraizadas em corpos diferenciados (Nicholson, 2000, p. 21). Para Godelier $^{2}$ (apud Scott, 1995), neste sentido, as "diferenças entre os corpos, relacionadas ao sexo, são constantemente solicitadas a testemunhar as relações sociais e as realidades que não tem nada a ver com sexualidade" ( $p$ 12).

A concepção de hermafroditismo e de transexualismo nos relatos médicos anteriores ao século XVIII são diretamente derivadas da concepção de homologia entre homens e mulheres. Se ambos estavam "distantes" enquanto gêneros distintos, tinham corpos muito mais "próximos" do que na concepção ocidental atual. As imitações do gênero oposto eram objeto de escárnio, como fica claro no teatro pós-renascimento, quando atores se vestiam como mulheres para caracterizar personagens femininos de forma burlesca (Laqueur, 1992). Ao mesmo tempo, porém, as mudanças de sexo espontâneas eram vistas como algo compreensível e natural nos discursos médicos. Se fosse possível a utilização da linguagem psiquiátrica atual para descrever outros

\footnotetext{
${ }^{1}$ Algumas destas tentativas revelaram-se porém, infrutíferas. Um exemplo citado por Laqueur (1992) é o da postulação do orgasmo vaginal, realizada por Freud, que encontrou considerável aceitação na sexologia de então, até ser veementemente negado em estudos nas décadas de 40 e 50 por Masters \& Johnson.
}

${ }^{2}$ GODELIER, Maurice. The origins of the male domination. New Left Review 127:17, 1981. 
períodos históricos, dir-se-ia que o transexualismo era muito mais aceito que o travestismo, tendência justamente contrária à das sociedades ocidentais contemporâneas. É somente quando os corpos de homens e mulheres tornaram-se incomensuráveis e uma longa distância passou a ser estabelecida entre eles que o transexualismo começou a ser concebido como uma longa jornada, tornando os relatos médicos do período anterior completamente inverossímeis.

Nos relatos médicos anteriores ao século XVIII fica claro como fenômenos relacionados ao corpo podem assumir conotações completamente diversas em contextos sócio-históricos diferenciados. Laqueur (1992) cita vários relatos médicos de casos onde mulheres transformavam-se em homens de forma espontânea, uma vez que, tendo a mulher pênis e testículos internalizados, algum incidente era capaz de promover a externalização de tais órgãos, o que fazia com que tal pessoa mudasse de sexo. Tal mudança era explicada pelo excesso de movimentos violentos por parte da mulher, pela ativação do calor interno pela atividade sexual, que empurraria os testículos (ovários) para fora, ou mesmo por algum acidente fortuito.

O hermafroditismo, da mesma forma, estava longe de ser considerado a aberração que se tornou no século XIX, já que, se havia uma homologia entre os órgãos sexuais do homem e da mulher, era natural que as misturas de ambos pudessem ocorrer. Este panorama começou a mudar substancialmente, porém, em meados do século XVIII, momento em que o hermafrodita passou a ser objeto de investigação para se descobrir o "verdadeiro sexo" por trás de seu corpo (Foucault, 1982a). No lugar de homologia e proximidade dos corpos passou a haver uma relação de total incomensurabilidade entre os mesmos. Instaurou-se a partir desse momento a necessidade de se descobrir por trás das aparências confusas o único sexo real e o perito passou a ser o responsável por apontar a qual sexo pertencia o indivíduo, que perdeu o poder de manter ambos ou mesmo de escolher por si próprio ser considerado homem ou mulher.

Se é na verdade do corpo que se passou a descobrir a verdadeira identidade de cada um (Foucault, 1982), não foi mais tolerada a existência de corpos "refratários aos escaninhos macho/fêmea (Fausto-Sterling, 2001, p. 67). Esta negação de qualquer 
possibilidade de mistura do masculino e feminino nos corpos pode ser criticada dentro de uma visão construcionista, uma vez que a formação de um sujeito é nesta entendida como fruto da identificação com um sexo e do repúdio ao que nele não se encaixa (Butler, 1993 p 3). Isto significa que desde a infância, em alguma medida, a criança absorve o gênero socialmente estabelecido em seu próprio corpo, suprimindo do mesmo as características correspondentes às do gênero oposto. (Butler, 2003, p. 108). O entendimento dos corpos como socialmente construídos permite a compreensão de que há a "masculinização dos corpos masculinos e a feminilização dos corpos femininos".(Bourdieu, 1998, p. 22), o que abre espaço para que possamos conceber, em decorrência, corpos masculinos feminizados e corpos femininos masculinizados.

\section{Transgêneros e corpo}

Dado este panorama histórico, é importante discutir o lugar que a manipulação do corpo assume entre transgêneros, uma vez que entre as características que estão presentes em algumas ou várias das identidades transgenéricas está a busca por elementos físicos definidores do gênero ou sexo opostos ao que corresponderia ao próprio.

A busca por um "novo" corpo assume um lugar central entre transgêneros, seja na transformação definitiva do corpo pela via cirúrgica ou hormonal, na transformação provisória do corpo por musculação ou depilação, no uso da vestimenta íntima ou social típica do masculino ou feminino, ou ainda na busca por gestuais e representações que possibilitem a associação com o gênero oposto. A constituição das identidades transgenéricas só é possível, desta forma, pela manipulação do corpo.

No caso de modalidades de transgêneros que envolvem algum tipo de mudança definitiva, como no caso dos(as) transexuais e das travestis, pode-se acrescentar que tais identidades só se tornam possíveis a partir do desenvolvimento das tecnologias médicas de transformação corporal. Cirurgias de realinhamento sexual, uso de hormônios e cirurgias plásticas são apropriadas de diferentes formas por travestis ou transexuais. Como vimos anteriormente, a apropriação caseira dos hormônios e silicone 
por parte de um contingente de homossexuais efeminados é um dos fatores que possibilitou a disseminação de travestis pelas ruas das grandes cidades brasileiras a partir da década de 70 .

Se as diferentes modalidades de transgêneros supõe, em alguma medida, a manipulação do corpo, há muita diferença entre elas no que diz respeito à reprodução ou não da crença na existência de um dimorfismo sexual "natural" no ser humano. No caso do transexualismo cirúrgico, por exemplo, parece haver antes uma conformação a essa crença. Nessa modalidade, que envolve a ablação peniana e a construção da vagina (ou a construção do pênis), parece estar implícita a idéia de que devam haver diferenças no corpo que justifiquem a identidade sexual. Se há relação de incongruência entre gênero e sexo, busca-se, pelas cirurgias de realinhamento sexual, uma equivalência total entre ambos. Para Kessler e McKenna (1985) tais cirurgias reforçam a idéia existente na maior parte das sociedades ocidentais modernas de que deva haver uma correspondência estreita entre gênero e sexo: "In a society that could tolerate lack of correspondence [entre sexo e gênero], there would be no transexual individual. There would be men with vaginas and women with penises or perhaps different signs of gender". (pg. 120). Stone (1991) observa de forma semelhante que os(as) transexuais dividem os territórios masculino e feminino sem estabelecer um espaço intermediário entre ambos (p 286-9). Ao fazê-lo, ganham aceitação social, mas perdem em complexidade e ambiguidade da experiência vivida (p. 295). Tal procedimento é tão absoluto que as transexuais "homem-para-mulher" acabam por se tornar mais femininas em aparência do que a grande maioria das mulheres (Shapiro, 1991, p. 253)

Em relação às travestis que frequentavam o Grupo, por outro lado, é possível considerar a presença de um movimento de resistência à idéia da incomensurabilidade entre os corpos masculino e feminino. Havia um ideal de corpo feminino a ser alcançado, como veremos a seguir, mas elas também eram submetidas às demandas da profissão, que exige a posse de um pênis. Nesse sentido, as travestis acabavam por construir um corpo que não era propriamente masculino ou feminino - ou era ambos, simultaneamente - criando ao mesmo tempo um universo de significações relacionado a essa ambiguidade corpórea. Uma vez que o corpo "tem funcionado como o significante 
da condensação das subjetividades no indivíduo" como mostra Hall (2000, p 121), somente um corpo ao mesmo tempo masculino e feminino daria conta de uma identidade que incorpora fortemente elementos masculinos e femininos.

Nas diferentes modalidades de transgêneros é evidente também a objetificação do corpo, tida quase consensualmente nas Ciências Humanas como uma característica da contemporaneidade. Uma vez que o corpo é um lugar privilegiado de controle, de atribuição de correção e normalidade, a manipulação do próprio corpo por parte dos indivíduos na busca por adequação social é uma decorrência lógica desse fato. Se somos julgados e classificados pelo nosso corpo, como mostra Le Breton (2003), há uma relação direta entre a transformação corporal e a busca por aceitação social. O narcisismo contemporâneo refletido no corpo é, assim, a contrapartida do controle social do mesmo: os indivíduos passam cada vez mais a buscar no corpo sua normalidade, mesmo quando aparentemente rompem com a mesma. Se o(a) transexual rompe com o imperativo biológico do sexo, e por isso transgride, ao mesmo tempo busca em sua transformação a normalidade do masculino (ou do feminino). Da mesma forma a aprendizagem do gestual tipicamente feminino por parte de cross-dressers, travestis e transformistas implica muitas vezes em um clichê do feminino, codificado de forma estereotipada e, portanto, normalizado.

Outro aspecto da virtualidade do corpo presente em algumas modalidades de transgêneros é o da dissolução das barreiras entre a roupa e o corpo. O corpo se torna na contemporaneidade tão maleável, tão modificável, que se torna quase uma vestimenta, como mostra Kehl (2002). Silva (1993) observou esta característica entre as travestis por ele estudadas, uma vez que estas supunham o próprio corpo como moldável, vendo-o como uma "vestimenta corrigível, costurável, enxertável" ( $p$ 123).

A objetificação e a maleabilidade dos corpos era particularmente perceptível, entre as travestis aqui estudadas, na apropriação que faziam das tecnologias de transformação do corpo. Isso leva Benedetti (2000) a afirmar, como vimos, que as travestis não buscavam sua verdade na interioridade, mas no próprio corpo. A exibição dos corpos recém siliconados era um evento cotidiano nos encontros. Nestes havia 
quase sempre alguém que tinha "bombado"3 recentemente e que exibia os novos atributos físicos às demais. A ansiedade em exibir o novo corpo era tamanha, que muitas vezes levava algumas travestis a não obedecer o prazo de repouso obrigatório para o silicone enrijecer e, assim, evitar deformidades:

Em um momento do encontro uma colega de L. comentou que sua calça estava "vazando".
De fato sua calça estava com uma mancha de silicone líquido atrás. Rapidamente esta se
tornou o centro das atenções. Contou que tinha aplicado silicone há três dias, nas nádegas.
As outras integrantes do Grupo disseram a ela para ir para casa repousar, para não ficar
"deformada".

Outro assunto preferido era o dos planos acerca das próximas aplicações e a troca de opiniões a respeito. Algumas vezes observei travestis modificarem completamente o corpo no decorrer de poucos meses, a ponto de não reconhecer a mesma pessoa depois da transformação. Em um caso particular, a mesma travesti começou a frequentar o Grupo ainda como homossexual efeminada, passou cerca de dois meses depois a se "montar", utilizando roupas femininas e peruca, e, finalmente, começou a tomar hormônios femininos e injetar silicone simultaneamente. Em cerca de seis meses mudou completamente sua aparência, seus gestos e sua voz.

A apropriação por parte delas das tecnologias de transformação do corpo era bastante peculiar e quase sempre alheia ao controle médico. Havia, por exemplo, uma série de "regras" sobre as formas adequadas ou não de se tomar hormônios que certamente seriam desaconselhadas pela totalidade dos médicos pelas altas doses e inconstância de utilização dos mesmos. Com relação à utilização do silicone, tal desautorização seria ainda mais evidente, uma vez que há riscos de infecção e reação alérgica com o uso de silicone industrial..

O uso de hormônios e silicone, embora muito comum, não era unânime entre elas. Algumas jamais fizeram uso de quaisquer destes métodos de feminização corpórea ${ }^{4}$ :

\footnotetext{
s O termo refere-se à aplicação caseira de silicone industrial e "bombadeira" refere-se à travesti especializada na aplicação do silicone.

${ }^{4}$ Minha observação é discrepante das de Silva (1993, p 133), Benedetti (2000, p. 74) e Pelúcio (2005a), que consideram que a condição travesti é definida pelo uso de hormônios, algo que, no Grupo, não era
} 
L. contou que nunca tomou hormônio e nem colocou silicone. Eu, que nunca tinha notado, estranhei e perguntei: 'Não, mesmo ?' Ela disse que não, que gostava do jeito que era e que ser travesti era 'algo daqui', apontando a cabeça.

Os cuidados estéticos cotidianos, porém, eram unânimes. As travestis pesquisadas sempre dedicaram boa parte do tempo dos encontros a temas como depilação, maquiagem, cuidados com cabelos, etc. Medicamentos e "simpatias" para queda de cabelo eram frequentemente citados. Por não dominar tais temas eu raramente era solicitado como interlocutor nas conversas. Por outro lado, era comum que compartilhassem tais assuntos com mulheres. Duas funcionárias da instituição onde o Grupo de encontrava eram frequentemente requisitadas para conversas neste sentido.

Com relação aos métodos "definitivos" de transformação corpórea, havia todo um universo de crenças entre as travestis a respeito dos mesmos. Pode-se afirmar mesmo a existência de uma tecnologia de transformação corpórea nesse sentido. Por este motivo, é necessário descrever tais métodos e sua significação para as travestis em itens específicos.

\section{Os Hormônios}

O uso de hormônios femininos entre as travestis estudadas estava baseado na crença de que estes ajudavam tanto no desenvolvimento das características corporais consideradas femininas - seios, formas arredondadas - como na diminuição das masculinas - como a voz grossa e a pilosidade. Quanto mais precoce o uso, maior se acreditava que seria seu efeito, o que fazia com que as mais velhas "doutrinassem" as mais jovens a respeito da necessidade de começar cedo seu uso.

considerado como elemento essencial para definição de quem seria - ou não - travesti. Ferreira (2003) sugere que as hormonioterapia era, em seu início, típica da região centro-sul do pais, tendo demorado a chegar em Belém, onde as travestis se utilizavam de recursos não-definitivos para se "montarem" (p. 43$4)$. 
As travestis do Grupo trocavam abertamente informações sobre quais hormônios deveriam tomar - e com que frequência - para desenvolver o corpo que desejavam, mas tais regras pareciam estar bastante submetidas ao desejo por transformações rápidas, o que fazia com que houvesse um uso abusivo dessas substâncias:

A. contou que tomava dois Perlutans [contraceptivo injetável] por dia [ou seja, o equivalente a 60 vezes a dose mensal que uma mulher necessita para evitar a concepção]. Assustei-me com a quantidade e perguntei a ela se não se sentia mal. Ela disse que não, que no começo tinha muita dor de cabeça, mas que depois o "corpo se acostumou"

A preferência pelos anti-concepcionais injetáveis, que supostamente causavam transformações mais rápidas, nem sempre era seguida por elas, devido ao fato da grande maioria ter silicone nas nádegas, o que restringia a aplicação nesta área. $A$ aplicação em outras áreas do corpo era referida como dolorosa ou como propiciadora de marcas corporais devido às frequentes picadas, o que levava grande parte a rejeitar tal procedimento.

As implicações indesejáveis do uso de hormônios femininos eram objeto de frequente discussão nos encontros. Uma delas referia-se à pretensa irritabilidade causada pelo uso intenso de hormônios ${ }^{5}$. Episódios de agressividade eram frequentemente justificados pelo uso exagerado de hormônios:

D. comentou que A. [citada no exemplo anterior e ausente no encontro] a tinha ajudado a espancar um cliente que não queria lhe pagar o combinado. Comentei que achava que ela tinha ”cara de santa”. Várias riram do meu comentário e contaram de alguns 'ataques' de A. Em um deles, disseram que A. 'quebrou um bar inteiro' porque o dono não quis lhe vender um drink. Relacionaram diretamente isso com os hormônios que tomava.

Outra intercorrência bastante citada referente ao uso de hormônios dizia respeito à suposta impotência gerada por seu uso. Tal problema afetava diretamente a vida profissional, uma vez que era comum o desejo dos clientes em ter relacionamento

\footnotetext{
${ }_{5}^{5}$ Citado também por Benedetti (2000, p 72) e Pelúcio (2005c), que relaciona esse nervosismo como busca de um elemento socialmente sancionado como feminino. Penso, contudo, que faltam elementos para justificar esta associação entre nervosismo e feminilidade no artigo da autora.
} 
sexual anal passivo com elas. Não havia, contudo, concordância total em relação a este ponto: enquanto muitas afirmavam ficar impotentes com o hormônio, outras diziam o contrário, mesmo tomando doses altas. Uma "solução de compromisso" frequentemente buscada era o uso de uma dosagem intermediária como resposta ao conflito entre o desejo de transformação corporal rápida e intensa e o possível risco de impotência ${ }^{6}$.

Frente à impossibilidade de ereção no relacionamento sexual com os clientes, as travestis estudadas lançavam mão de alguns artifícios. Um dos mais comuns era o recurso a outra modalidade de prática sexual, como o sexo oral, culpando ao mesmo tempo o cliente que reclamasse, atribuindo a falta de ereção ao fato do mesmo ser pouco atrativo sexualmente. Outra possibilidade era a da utilização de um dos chamados "truques da mona", enganando o cliente ao simular uma introdução anal com o pênis quando na verdade isso era feito com os dedos.

Se a ereção ainda era possível para algumas travestis que tomavam hormônio, a ejaculação era considerada totalmente indesejável. Uma crença comum a elas era a de que a ejaculação expulsava o hormônio feminino do corpo, tornando sua utilização inútil ${ }^{8}$ :

Em uma discussão sobre o uso de hormônios, P. contou que estava tomando regularmente e que não ficou 'brocha'. V. se voltou a ela e perguntou: 'mas você não tá gozando, tá?’ Quando ela respondeu afirmativamente, $\mathrm{V}$ emendou 'desse jeito não vai adiantar nada, bicha, você vai por todo o hormônio para fora”.

Independentemente dos reais efeitos do hormônio, é interessante observar que tais crenças trazem consigo certos elementos imaginários. Neste caso, parecia haver a transposição da "luta" entre o masculino e o feminino no corpo para o campo dos hormônios, entre o masculino fabricado e o feminino ingerido. Agir "como homem",

\footnotetext{
${ }^{6}$ Essa tentativa de conciliação é também citada por Benedetti (2000, p 73)

${ }^{7}$ Há determinados “segredos' que as travestis relutam muito em compartilhar, que são chamados dessa forma e que não devem ser perguntados diretamente. Às vezes são revelados depois de muito tempo de convivência, de maneira casual.

${ }^{8}$ Citado por Pelúcio (2005c). Kulick (1998) cita também o receio das travestis em relação à diminuição dos seios caso ejaculassem (p 86)
} 
ejacular, significa eliminar o feminino do corpo. Ao mesmo tempo, tal crença parecia conferir ao próprio esperma uma ambiguidade, uma vez que este seria o veículo condutor do hormônio feminino para fora do corpo.

\section{O Silicone}

Frente à demora pela feminização corpórea via hormônios e suas possíveis intercorrências, o silicone aparecia muitas vezes para as travestis pesquisadas como uma alternativa mais atraente. Além disso, considerava-se que as formas corporais adquiridas pelo uso do silicone eram definitivas, enquanto as conquistadas por meio de hormônios só se mantinham pelo uso contínuo, sob pena de se perderem.

Entre as travestis com que tive contato, raras recorreram a cirurgias plásticas para implantação de próteses de silicone, devido ao seu preço elevado ${ }^{9}$. Muito mais frequente era a aplicação caseira, feita por "bombadeiras", travestis especializadas na aplicação do silicone líquido, prática atraente por seu preço ${ }^{10}$ e por oferecer possibilidades que a cirurgia plástica tradicional não oferece, uma vez que o controle sobre os procedimentos na Medicina é certamente muito mais rígido do que o executado pelas "bombadeiras".

A aplicação de silicone líquido é uma prática que envolve vários riscos. Há a possibilidade de reação alérgica, de rejeição ao silicone e do mesmo migrar pelo corpo. Além disso, o silicone, uma vez aplicado, adere ao tecido do corpo, tornando-se quase impossível sua remoção. Por este motivo, é uma prática proibida em diversos países, mesmo aos cirurgiões plásticos. Nos EUA, por exemplo, sua utilização foi proibida pelo FDA em 1965, após muitos pacientes apresentarem as intercorrências citadas ${ }^{11}$. Sua utilização sob a forma de próteses ainda é objeto de polêmica exatamente pelo fato da

\footnotetext{
9 Pelúcio (2005c) observa, em contrapartida, que as travestis de alta renda não "bombam".

${ }_{10}$ Duas travestis do Grupo que colocaram prótese de silicone nos seios pagaram R $\$ 3.000,00$ cada uma por tal procedimento (dados de 2002). "Fazer os seios" com uma bombadeira, na mesma época, custava por volta de $\mathrm{R} \$ 300,00$, ou seja, dez vezes menos.

${ }^{11}$ Fonte: www.breastimplantinfo.org
} 
possibilidade da prótese se romper e o silicone entrar em contato com o corpo, gerando as mesmas reações. Evidentemente estes riscos se agravam nas aplicações caseiras, uma vez que o silicone utilizado, de origem industrial, é sujeito a impurezas e é aplicado em grande quantidade, por pessoas muitas vezes sem o preparo adequado. Por este motivo, tal prática é objeto de intenso controle policial, o que faz com que ocorra na mais absoluta clandestinidade ${ }^{12}$. Devido a isso, existem "bombadeiras" em número reduzido e somente em algumas grandes cidades brasileiras ${ }^{13}$.

Todo um campo de crenças a respeito da injeção de silicone líquido era compartilhado nos encontros. Eram comuns discussões a respeito de quem era a melhor "bombadeira", das formas de se evitar os efeitos colaterais das aplicações, das áreas do corpo a serem trabalhadas, etc. Entre as recomendações seguidas pelas travestis referentes ao silicone estavam o uso de antibióticos e corticóides no período imediatamente anterior e no posterior à aplicação, para prevenção de possíveis infecções e reações alérgicas, respectivamente. Outra recomendação era a de um período de repouso, variável conforme o local de aplicação, para que o silicone se solidificasse e não escorresse para outras áreas.

A figura da bombadeira era bastante ambígua: ao mesmo tempo em que concretizava uma liberdade em relação ao controle médico, que impunha preços e parâmetros éticos para a cirurgia plástica, tornava muitas delas vítimas permanentes de procedimentos mal-realizados $^{14}$. Era grande o número de travestis do Grupo que

\footnotetext{
12 A perseguição policial às "bombadeiras" acaba gerando um efeito perverso. Muitas vezes estas já desenvolveram alguma experiência com aplicações, o que contribui para diminuir o risco da prática. Ao serem presas, cedem espaço para as iniciantes, muitas vezes ajudantes que apenas assistiam às aplicações, gerando um aumento dos riscos.

${ }_{13}$ Em Belém, por exemplo, cidade com grande mercado sexual, não havia nenhuma "bombadeira", segundo Ferreira (2003, p 55)

${ }^{14}$ Um outro dado interessante referido pelas travestis do Grupo referia-se ao fato da utilização caseira de silicone estar transcendendo os limites do próprio segmento das travestis. Diziam que as "bombadeiras" de São Paulo estavam aplicando silicone também em mulheres, desejosas de formas corporais mais evidentes, e em homens adeptos do fisiculturismo, em busca de aparentar ter mais massa muscular. Isso sugere que tal prática pode estar se tornando uma alternativa para pessoas de baixa renda que não tem acesso aos procedimentos cirúrgicos por motivos financeiros, configurando-se como uma espécie de "plástica para pobres". Esta proliferação do uso é confirmada por algumas reportagens jornalísticas ("Silicone deixa três pessoas em estado grave" - O Globo - 4/11/2004; "Uso de silicone industrial causa perda de seios"- Folha de S.Paulo 03/11/2004)
} 
apresentavam acúmulo de silicone nos tornozelos e pés, devido ao pouco tempo de repouso após aplicação nas coxas, o que deixava os mesmos com a aparência de "inchados". Mais raramente, o mesmo tipo de deformação podia ser observado em algumas delas nas "maçãs" do rosto - gerando uma aparência de "bochechas caídas". Um risco ainda mais grave era o dos seios perderem o formato, com o silicone se deslocando pelo peito:

P. contou que quando 'fez o peito', bobeou e tirou o cabo de vassoura [que usualmente é colocado entre os seios e amarrado ao corpo até que o silicone se solidifique] antes da hora, o que fez com que o silicone escorresse. Foi no Hospital das Clínicas para retirá-lo. mas grande parte já tinha aderido ao tecido e não pode ser recolhido. Disse que ficou com cicatrizes horríveis e que desconfiava que eram resultado de incompetência do médico que a operou, ou, pior ainda, que foram feitas propositalmente por ele para castigá-la.

Uma das causas do aumento do risco do silicone escorrer era o fato de muitas delas não seguirem o período de repouso recomendado, por motivos financeiros ou pelo desejo de exibir as novas formas conquistadas. Isto também facilitava a formação dos "mondrongos", que correspondiam a deformidades da parte "feita" com silicone, geralmente nádegas, quadris ou coxas, devido a algum tipo de pancada, acidental ou não.

Frente ao uso do silicone industrial, claramente não-recomendável em termos de saúde, a intervenção realizada no Grupo era baseada nas estratégias de redução de danos, descritas na introdução deste estudo. Partia-se do pressuposto de que as travestis iriam aplicá-lo de qualquer forma. Sendo assim, era melhor que o aplicassem reduzindo as consequências adversas. Toda uma série de recomendações era com frequência desenvolvida neste sentido: que se evitasse recorrer a "bombadeiras" iniciantes, mesmo que isto envolvesse um custo maior, que se verificasse a procedência do silicone, dando preferência à aquisição do mesmo diretamente da loja ${ }^{15}$, que se evitasse a aplicação de uma quantidade muito grande em uma única sessão,

\footnotetext{
${ }^{15}$ No município de São Paulo, as lojas não vendem silicone diretamente para travestis, o que faz com que seja necessário que alguma conhecido, “vício” ou “marido”, vá adquirir para elas.
} 
que se fizesse uma reserva financeira para os dias de repouso, evitando desta forma a necessidade de "batalhar" antes da hora.

Durante o período em que ocorreram os encontros, pude perceber que a utilização de silicone industrial como estratégia principal de feminização corpórea era mais comum entre as travestis de menor rendimento. Considero haver pelo menos duas razões que expliquem isso. A primeira delas refere-se ao fato destas travestis, por viverem em situação de penúria econômica, não poderem abrir mão de clientes desejosos de relacionamento sexual passivo, o que dificultava o uso alternativo de hormônios. A segunda relaciona-se à necessidade de ressaltar as formas femininas, de maneira a compensar a perda de atrativos físicos ocasionada pela idade:

J. [travesti de cerca de 45 anos, que nunca tinha aplicado silicone] veio ao Grupo nitidamente 'bombada'. Quando questionada por outra travesti se tinha colocado na boca, disse que sim e contou que tinha "feito" os seios, a boca e a testa. Mencionou tal necessidade exatamente pelo fato de não ser mais jovem.

O uso do silicone era objeto frequente de preocupação entre elas. Muitas estabeleciam um "projeto" de tudo o que precisava ser mudado no corpo, das novas aplicações à correção das imperfeições geradas por aplicações não tão bem sucedidas (os "mondrongos"). A impressão que sempre tive era que o corpo estava em permanente construção, não sendo nunca finalizado, uma vez que havia sempre algo a ser modificado em direção a um corpo imaginado perfeito ${ }^{16}$.

Em relação a essa permanente siliconização do corpo, as travestis referiam que de fato o uso poderia virar um vício bastante arriscado. Isso porque havia uma crença bastante frequente de que o corpo comportaria somente uma certa quantidade de silicone, acima da qual a aplicação se tornaria perigosa. Circulavam entre elas relatos de falecimento do travestis após terem "bombado", que eram acrescidos dessa explicação.

Em relação aos impedimentos ao uso do silicone, além do medo das intercorrências já descritas, eram comuns as referências às fortes dores inerentes à

\footnotetext{
${ }^{16}$ Benedetti (2000) também cita o exaustivo planejamento das futuras aplicações de silicone (p. 80)
} 
aplicação. A dor referida não me parecia de forma alguma imaginária, pois, como o silicone é um líquido espesso, a agulha utilizada para a aplicação deve ser grossa, o que faz com que as "bombadeiras" utilizem seringas e agulhas veterinárias, próprias para vacinação de gado. As picadas não cicatrizam facilmente, fazendo-se necessário o uso de pontos cirúrgicos, ou, mais comumente, de cola do tipo "super-bonder" para fechar o ponto da picada. Como cada aplicação envolve várias picadas, não é difícil imaginar a dor intensa que tal procedimento gera.

As dores da aplicação do silicone eram frequentemente citadas pelas travestis pesquisadas como "as dores de ser mulher". Tal descrição era também comum em referência às dores dos procedimentos depilatórios, principalmente o que utiliza cera quente. Pode-se observar novamente aqui a representação da mulher como alguém que sofre, presente em outros pontos já discutidos, como no sofrimento que se acredita que os "maridos" frequentemente impingem às mulheres (ou travestis).

\section{A "mulher super-sedutora"}

A necessidade de ter um corpo feminino e de se vestir e se comportar como mulher entre as travestis estudadas tinha certamente relação com a prostituição, como veremos no capítulo seguinte. Mas a forma como se dava a construção do corpo e dos gestuais certamente transcende em muito os domínios dessa atividade. Se na relação com o "marido" predominava a figura da mulher submissa, nos cuidados corpóreos era um outro tipo de mulher que emergia, a mulher super-sedutora, figura que passou por algumas transformações históricas, como a "femme fatale" da segunda metade do século XIX e a "vamp" do início do século XX. A travesti que conseguia incorporar suficientemente tal representação de mulher era chamada por elas de "mulherão"

Rago (1991) mostra que no imaginário do final do século XIX e início do XX, em São Paulo, havia uma forte associação entre a figura da prostituta e a da femme fatale", que aparecia na literatura, jornais e romances como "destruidora dos elos racionais de civilidade" (p. 44). Tais figuras não se superpunham totalmente, uma vez que a "femme fatale" é forte, não se apaixona nunca e não é obrigada a comercializar o próprio corpo" 
(p 203). Ao se fundir com a imagem da "vamp" do cinema a partir da década de 10 do século XX , passa a ser representada como a uma mulher poderosa e sensual, "cheia de artifícios, ousada e extravagante" e "dotada de instinto sexual indomável, selvagem e insaciável" ( $p$ 202). A partir da década de 30, para a autora, porém, a mulher fatal progressivamente se torna mais charmosa e sensual do que cruel, sucumbindo mais facilmente à sedução masculina, principalmente no cinema norte-americano.

A mulher "vamp" mostra a exacerbação do componente "sedução", atributo comum à mulher burguesa, como mostra Morin (1969, pg 150). Para o mesmo autor, essa mulher, disseminada pela cultura de massa, passou a chamar a atenção especialmente "para os caracteres sexuais secundários (cabelos, peitos, boca, olhos), para os atributos erógenos (roupas de baixo, vestidos, enfeites), para um ideal de beleza delgado, esbelto - quadris, ancas e pernas" (pg 147). Tal representação de mulher, para ele, é fruto da conjunção entre o erotismo feminino e o movimento do capitalismo moderno, que procura estimular o consumo (pg 126), cabendo à mulher a função de transmitir o desejo a ela direcionado às mercadorias às quais se associa, erotizando-as dessa forma.

Para Morin (1969), se a mulher sedutora é o objeto de desejo masculino, é, também e de forma talvez mais intensa, modelo identificatório para as mulheres (pg 150). As mulheres burguesas e, ao longo do tempo, também as das camadas populares, vão absorver tal modelo, desvinculando-a da figura da prostituta, figura na qual a mulher super-sedutora ficou por muito tempo subsumida. ${ }^{17}$. A mulher supersedutora pode ser vista também como a contrapartida no âmbito privado da progressiva emancipação da mulher na esfera pública, representada pelo acesso às carreiras tradicionalmente masculinas. A iniciativa frente ao contato com os homens e a busca pela realização sexual são elementos importantes desse imaginário (Passerini, 1990, pg 382).

Diversos autores observam ser a mulher super-sedutora um modelo recorrente de feminilidade buscada por diferentes modalidades de transgêneros em outros países.

\footnotetext{
17 Rago (1991) mostra, em um momento histórico anterior, as mulheres paulistanas ainda presas entre as atração das novidades comerciais voltadas à sedução, veiculadas pelas revistas femininas, e o fantasma da prostituição, ao qual a "femme fatale” ainda estava fortemente associada” (p 66)
} 
Woodhouse (1989, p 142) mostra que os(as) cross-dressers ingleses(as) tinham uma tendência clara pela busca de uma aparência feminina extrema, com o uso intenso de maquiagem e roupas íntimas erotizadas. Newton (1979, p. 57) observa que as transformistas $^{18}$ norte-americanas representavam as mulheres em sua forma mais excitante e desejável para os homens, o que estava associado a seios grandes, quadris largos, rosto jovem, maquiagem, jóias, brincos, cabelos longos, vestido preferencialmente curto - e sapato de salto alto (p. 49). A crítica constante feita à apropriação desse modelo de mulher por transgêneros diz respeito à reificação da associação da feminilidade com sedução que ela opera, como se a sedução fosse o que caracterizasse a mulher em última instância, o que denota um reducionismo sexista. Para Woodhouse (1989), por exemplo, o cross-dressing se baseia na utilização de imagens estereotipadas de mulher que foram usadas para objetificar e oprimir as mulheres (pg 145). Mais incisiva é a critica feita por Raymond (1979) ao transexualismo, que considera ser movido pelo desejo dos homens de se apropriar simbolicamente do poder de reprodução das mulheres ${ }^{19}$. De forma semelhante, Stone (1991) considera a "mulher" construída pelo(a) transexual como um fetiche masculino (p. 285-6)

No caso brasileiro, Green (2000) observa forte associação entre alguns segmentos de homossexuais e o "culto" a divas hollywoodianas e às estrelas do rádio, na década de 50, em São Paulo e Rio de Janeiro. Alguns homossexuais efeminados chegavam a adotar os nomes das atrizes e imitar as mesmas (p. 164-8), o que era mais intenso no caso dos(as) transformistas da década de 60 ( $p$ 378). Em relação às travestis, especificamente, alguns autores ressaltam a construção de um feminino exagerado, "kitsch" (Silva, 1993, p. 160), produto da imaginação masculina (Terto Jr, 1989, p. 7). Vale (2000) descreve, entre as travestis de um cinema pornô de Fortaleza, as performances cinematográficas que as mesmas faziam ao lado da tela, imitando as atrizes dos filmes (p. 13), o que mostra a efetividade do cinema como veículo identificatório, algo assinalado por Hall (2000, p. 113).

\footnotetext{
18 Traduzo o termo "female impersonator" como transformista pelo fato da descrição de Newton mostrar uma grande semelhança entre estes(as) e os(as) transformistas brasileiros(as).

19 Um argumento um tanto exagerado neste sentido é o de Welzer-Lang (1994) para quem as diversas modalidades de transgêneros correspondem a uma reação dos homens à liberdade alcançada pelas mulheres, o que os faz construir um mundo que prescinde delas (p. 185).
} 
A busca por um certo perfil corporal, voluptuoso, por uma certa forma de se vestir, o mais atraente possível, e por um uso intenso da sedução nos relacionamentos era algo que em muitos momentos pude observar nas travestis estudadas, o que sugere ser a mulher "vamp" um dos elementos identificatórios para as mesmas. Nesse sentido, encarnavam o que poderíamos chamar de "hiper-feminilidade", em um exagero de características tidas como típicas das mulheres ${ }^{20}$. O corpo almejado, por exemplo, não era o corpo que as mulheres mais comumente possuem em nossa sociedade, mas um corpo onde algumas características corporais femininas eram ressaltadas, onde os seios, as nádegas e coxas eram trabalhados de forma a se tornarem volumosos o máximo possível. Da mesma forma, a roupa era escolhida muito em função de seu poder de sedução, de exibir as formas corporais. O mesmo ocorria em relação aos penteados e cortes de cabelos, frequentemente aumentados com apliques. Mexer nos cabelos longos era outro ato muito recorrente entre elas, em uma tentativa de mostrar sensualidade ${ }^{21}$.

Se a identidade da mulher "fatal" muitas vezes se misturava à da prostituta entre elas, devido à necessidade de sedução do sexo oposto presente em ambas, em vários momentos essas identidades se descolavam, como no cotidiano exame do próprio corpo, diretamente ou por espelhos. É em frente ao espelho que muitas travestis o examinavam em busca de imperfeições a serem corrigidas e ensaiavam os gestuais tidos como tipicamente femininos, em uma busca da apropriação de um modelo de "femme fatale". Havia mesmo uma certa competição no Grupo, a respeito de quem se mostrava mais feminina, ou, mais apropriadamente, hiper-feminina, o que ocorria de forma ainda mais enfática na presença de algum "bofe", homem com aparência

\footnotetext{
20 A hiper-feminilidade representada acaba suscitando, como pude observar diversas vezes, reações bastante interessantes em mulheres que convivem com travestis, que vão desde a admiração frente ao corpo das mesmas até uma necessidade de desqualificar a feminilidade representada corporalmente por elas. No primeiro caso lembro-me particularmente de uma funcionária da instituição onde o Grupo de reunia, que repetia semanalmente seu desejo não realizado em ter um corpo como o delas.

${ }^{21}$ Como nem todas as travestis conseguiam manter cabelos compridos naturais, tê-los era sinal de status no Grupo, o que fazia com que jogar o cabelo para o lado fosse usado como um recurso para mostrar superioridade. O mesmo gesto foi observado por Benedetti (2000, p 55) entre as travestis de Porto Alegre.
} 
máscula, com quem pudessem ter algum tipo de relacionamento ${ }^{22}$. A exibição e a necessidade do reconhecimento entre elas próprias de uma feminilidade "supersedutora", em um contexto relacional distinto daquele relativo à prostituição, foram diversas vezes presenciadas por mim:

J. [travesti mais velha que frequentava o Grupo, aparentando cerca de 55 anos] veio à festa [de final de ano, realizada pelo próprio Grupo] com uma roupa bastante sofisticada. Estava com um vestido preto, curto, todo rendado, e foi bastante elogiada pelas demais. D. comentou que ela estava uma "diva".

R. [travesti que referia já ter vivido na Itália e que agora trabalhava como cabeleireira] contou que costumava em ir uma boate da região central de São Paulo, onde muitas travestis se encontravam de madrugada para dublar, cantar e dançar. Pensei que se tratava de uma casa de shows com transformistas e ela me disse que não. Tratava-se de um espaço organizado pelas próprias travestis onde elas "curtiam o final da noite" entre elas, assistindo umas às outras.

Um outro aspecto que evidenciava a identidade da "mulher fatal" como um dos fragmentos identitários constituintes da identidade travesti era o dos nomes "de mulher" ou "de bicha" por elas escolhidos. Infelizmente tais nomes não podem ser reproduzidos aqui por motivos éticos, mas algumas características comuns a eles podem ser descritas. Era muito comum entre elas a utilização de nomes duplos, ou seja, de um nome e de um sobrenome, frequentemente estrangeiros. Muitos desses eram, literalmente, nomes ou sobrenomes de "divas" do cinema. Quando não, eram nomes carregados de ípsilons, dáblios, cás e duplas consoantes, difíceis de serem registrados ${ }^{23}$. Tal escolha de nomes transparecia a busca por um ideal de feminilidade típico das representações veiculadas pela cultura de massas ${ }^{24}$.

\footnotetext{
${ }^{22}$ Em situações de rivalidade, descaracterizar a aparência pouco feminina da outra travesti era um artifício frequentemente utilizado.

${ }^{23}$ Algumas vezes eram compostos de um nome simples, às vezes dados pelos femininos dos próprios nomes "de homem" das travestis, conjugado com um sobrenome estrangeiro. Outras vezes, o primeiro nome, estrangeiro, era acrescido do nome da cidade ou estado de origem.

${ }^{24}$ Pelúcio (2005a) observa também a escolha de nomes comuns atrizes e musas hollywoodianas entre as travestis que estuda. Neusa de Oliveira (1994) considera que em Salvador as travestis copiam explicitamente as divas do cinema e as estrelas do mundo musical (p. 38).
} 
No que diz respeito à discussão apresentada anteriormente, a respeito do quanto a assimilação da mulher super-sedutora pelas travestis significaria a reificação da feminilidade nesses termos, consideramos aqui tal visão "negativa" dessa apropriação pode ser contraposta à interpretação de que as travestis, ao fazê-lo, ao mesmo tempo desconstróem a idéia de um gênero "natural". O transformismo e o "drag" tem sido apontado na literatura das Ciências Humanas como potencialmente transgressivo, na medida em que rompem com a idéia de que há naturalidade na identidade de gênero, mostrando que este pode ser construído (Tyler, 1991, p. 32 e 53). Para Butler (2003), a performance drag mostra que não há um corpo nem um psiquismo que explique o gênero, revelando "a estrutura imitativa do próprio gênero" (p 196). Ao exagerar as normas heterossexuais do gênero, o drag não é meramente uma imitação de um "projeto original", uma vez que ele acaba por mostrar que o próprio "original" é construído (Butler, 1993, 124), constituindo-se, desta forma, simultaneamente como uma sujeição e uma subversão ao sistema de gêneros estabelecidos (p.128), argumento este que consideramos perfeitamente aplicável ao caso das travestis aqui estudadas.

Se muitas das características corpóreas tipicamente masculinas podiam ser "diminuídas" pelos hormônios e silicone ${ }^{25}$, na construção da mulher super-sedutora, um elemento-chave associado à masculinidade, porém, era objeto de intensa problematização neste processo: o pênis. A relação das travestis com o próprio pênis, dada sua complexidade, merece ser analisada em um item à parte.

\section{A“neca" (pênis)}

Para se referirem aos pênis dos clientes, vícios, ou "maridos", as travestis pesquisadas se utilizavam de termos comuns em nossa linguagem. No entanto,

\footnotetext{
${ }^{25}$ Além destes, uma série de procedimentos se voltava à tentativa de eliminação das características tidas como masculinas pelas travestis, como a depilação, as tentativas de afinar a voz, o uso de perucas como corretivo para a queda de cabelos, etc.
} 
utilizavam o termo "neca" como referência ao próprio pênis ou ao pênis de outras travestis. O uso de algum outro termo como referência ao pênis de uma travesti era feito somente em um contexto de crítica (por exemplo, em relação a andar exibindo-o na rua à noite, para atrair clientes). Levei, no período de funcionamento do Grupo, pelo menos duas "broncas" por ter utilizado outras palavras, indevidamente, como referência à "neca":

Em uma discussão sobre a perseguição de um delegado às travestis da Av. [zona norte de $\mathrm{SP}$ ] várias delas falaram que as colegas estavam abusando ao se exibirem nuas na rua. Perguntei se elas estavam somente nuas ou se também estavam "puxando o pau" [referência ao ato de se masturbar lentamente, com o objetivo de manter o pênis em ereção, comum em alguns contextos homoeróticos]. Nesse momento, P. me deu um corte e falou: ”É neca, Marcos, puxando a neca!"

O termo "neca" é um dos termos incorporado pelas travestis em sua gíria cotidiana, que como vimos, é considerada ser descendente de dialetos iorubás e nagôs. Em Português, porém, tem a significação de negação, de "nada", o que nos faz pensar de antemão na complexidade de significações que o pênis assume entre as travestis estudadas $^{26}$.

Embora não fosse certamente a maioria, uma parcela significativa de travestis expunham nos encontros seu desejo de se submeter à cirurgia de transgenitalização. Ter um pênis, porém, como foi observado anteriormente, era importantíssimo às travestis de baixa renda, que não podiam abrir mão dos clientes que desejam sexo anal passivo. Durante cerca de um ano, uma travesti "operada" frequentou o Grupo e esta contradição foi observada diretamente por mim:

G. veio pela primeira vez e se tornou o centro das atenções. Disse ter voltado recentemente da Europa. É bastante articulada e aparenta cerca de 50 anos. Contou que é operada - fez a cirurgia em Marrocos, na década de 70, o que despertou um grande interesse no grupo. Todas queriam saber como foi a operação, se era verdade que não se gozava mais, etc. G.

\footnotetext{
${ }^{26}$ Silva (1996) considera que entre as travestis podemos perceber uma nítida "feminização do membro" (p. 63). Apesar de tal idéia ser instigante, penso que o mais apropriado seria falar em uma negação do pênis do que em uma feminização do mesmo, uma vez que o pênis é talvez o elemento mais fortemente associado à masculinidade em nossa cultura.
} 
disse que mostraria sua 'buceta', mas que ficaria constrangida com minha presença. Fiquei aliviado, pois também ficaria constrangido em observá-la. Saí da sala para que pudessem vêla, combinando que me chamassem depois. Quando voltei, havia um silêncio total. Tentei introduzir algum tema para discussão, mas nada vingou. Resolvi encerrar o encontro.

Em referência ao encontro da semana passada, ouvi V. falando baixinho para L: "esquisita a buceta daquela bicha, né?”27. Acho que isso explica o silêncio que houve.

G. reclamou que os clientes no Brasil eram muito passivos, ao contrário dos europeus, e que por isso às vezes tinha que utilizar um pênis artificial nas relações com eles.

Em uma discussão sobre cirurgia [G não estava presente] L aconselhou P., dizendo que, para operar, ela teria que estar com a "vida feita”, caso contrário acabaria ficando como G. , tendo que usar um "pau de borracha”.

A contradição entre o desejo pela feminilidade e a posse de um pênis era também evidenciada por outro fato: a preferência dos clientes pelas travestis com pênis maiores. Ser "bem-dotada" era uma garantia de maiores ganhos, o que gerava um sentimento de ambiguidade naquelas que o eram, uma vez que tinham maior rendimento que as outras, o que era a princípio era positivo, mas o faziam graças a um atributo tipicamente masculino, o que era desvalorizado.

Em uma discussão sobre preferência dos clientes, P. disse que eles preferiam as loiras como ela. V. se virou para ela e disse: "É nada, meu bem, isso é por causa do tamanho da sua neca" e fez um gesto mostrando que P. era "bem-dotada" P. ficou nitidamente constrangida.

Outro obstáculo à cirurgia de transgenitalização bastante citado por elas referiase à possível interrupção de se ter prazer sexual pela via do orgasmo. Embora a impossibilidade do orgasmo, por si só, fosse algo constantemente temido, ainda mais o era a possibilidade de enlouquecer. Uma crença muitas vezes revelada nos encontros era de que, com a operação, o esperma da travesti não teria por onde sair e subiria até a cabeça, enlouquecendo- $a^{28}$.

\footnotetext{
${ }^{27}$ Silva (1993) ao ver a genitália de uma travesti operada, descreve a impressão de que a mesma "não forma uma gestalt" (p. 45).

${ }^{28}$ Kulick (1998) cita, de forma semelhante, a crença entre as travestis que estuda de que o sêmen acumulado formaria uma pedra no cérebro, enlouquecendo a pessoa (p 86)
} 
A crença que associa a impossibilidade de orgasmo e o enlouquecimento nos mostra o quanto entre as travestis pesquisadas o "ser travesti" era muitas vezes tomado como algo definitivo. Mesmo após a cirurgia, concebia-se que o esperma, masculino, continuaria a ser produzido e atuar no corpo, o que parecia indicar que as travestis nunca seriam plenamente mulheres, mesmo que "operadas". Dentro dessa compreensão, fazia sentido continuar tratando uma "operada" como travesti29, conforme vimos no capítulo sobre Identidade.

A masculinidade, neste sentido podia ser diminuída, aplainada, corrigida, extirpada, mas nunca desaparecia por completo da travesti. Não se acreditava, por outro lado, que as travestis pudessem "virar homem" plenamente, o que se mostrava evidente no desdém com que em algumas ocasiões eram referidas as que buscavam deixar de ser travestis. Essas conversas eram consequência dos convites que uma Igreja Neo-Pentecostal, localizada na região central de São Paulo, fazia periodicamente às travestis nas ruas, para um "almoço de domingo" destinado à conversão religiosa e à tentativa de convencimento das travestis em deixar de sê-lo, o que acompanhava inclusive o oferecimento de retirada cirúrgica do silicone implantado ${ }^{30}$ :

\footnotetext{
A. contou que foi no almoço da Igreja ( ) e ficou impressionada por ter encontrado uma (ex)travesti [conhecida de várias do Grupo]. Disse que ela estava com barba, tinha tirado o silicone e "nem parecia mais bicha". As demais integrantes começaram a brincar com o fato, dizendo que ela deveria estar “dando” para todos os pastores da Igreja.
}

A permanência eterna em um lugar de ambiguidade, sem nunca ser plenamente "mulher" nem "homem" mostra que as travestis do Grupo pareciam reivindicar a própria identidade de forma essencialista, algo, como mostra Woodhouse (1989), frequente em diversos grupos de transgêneros. Ser travesti, para aquelas aqui estudadas, parecia implicar em sê-lo para sempre.

\footnotetext{
${ }^{29}$ Benedetti (2000, p 105) e Silva (1993, p 131) relatam, de forma semelhante que as 'operadas' continuam sendo consideradas travestis.

30 Araújo Jr (2006) relata uma interessante história de “conversão” religiosa de uma (ex)travesti em Londrina (75-82).
} 


\section{A "Tia” (AIDS)}

A AIDS era muito presente no universo das travestis investigadas. Mesmo para as que não eram HIV-positivas, ocupava um lugar muito importante. Isso se explica por uma razão bastante simples: as travestis foram e ainda são um dos grupos sociais mais vulneráveis à infecção pelo HIV no Brasil. As travestis foram, e aqui é importante usar um termo incisivo, dizimadas pelas complicações relacionadas à AIDS no período da segunda metade da década de 80 e da primeira metade da década de 90 . Este é um dos principais motivos pelos quais hoje há poucas travestis com faixa etária acima dos 40 anos, em comparação com as mais jovens ${ }^{31}$, algo que pude perceber no Grupo e que me foi várias vezes confirmado pelas suas integrantes. Alguns estudos mostram que, praticamente desde o surgimento da AIDS, a incidência de HIV entre travestis e o número de portadores que desenvolveram a doença são muitíssimo altos $^{32}$. A situação de marginalização a que elas estão submetidas no Brasil, sem dúvida, está diretamente relacionada aos altos índice de infecção, uma vez que, conforme mostra Parker (1994), as relações de poder e dominação estruturam a vulnerabilidade social e individual frente à AIDS (p. 60).

A AIDS era quase sempre referida entre elas pelo termo "tia". Este uso correspondia a uma estratégia de evitação da palavra, o que mostra o "peso" que representou desde seu início para as travestis enquanto segmento social. Por isso era um termo evitado entre elas: fui corrigido várias vezes ao falar "AIDS" nos encontros, até o momento em que passei a adotar também "tia". Mas "tia" é também um termo comumente utilizado em nossa cultura para se referir a pessoas mais velhas, muitas

\footnotetext{
${ }_{31}$ Também citado por Kulick (1998, p 39) e Benedetti (2000, p. 30). Um outro motivo importante referese aos assassinatos cometidos contra travestis, principalmente por clientes, policiais ou outras travestis, tema ao qual retornaremos mais adiante.

32 A divulgação dos índices de infecção por HIV entre profissionais do sexo é um assunto polêmico. Por um lado a pesquisa se faz necessária para orientar campanhas de prevenção e programas de atendimento voltados a essa população. Por outro, a publicação de tais resultados pode contribuir para aumentar o estigma que já existe sobre esses profissionais e, mais grave ainda, para afastar os clientes, afetando de forma negativa sua vida profissional. Em relação a travestis, embora muitos destes dados já tenham sido publicados em diferentes contextos, considero que reproduzi-los aqui seria indevido devido aos motivos apresentados. Entre os fatores que tem maior correlação com o índice de infecção citados nestes estudos estão a maior idade, o alto consumo de drogas e o maior tempo de prisão durante a vida.
} 
vezes implicando em uma relação de familiaridade com a pessoa referida. É neste sentido que acredito que se dava a apropriação do termo por elas, refletindo um sentimento de proximidade, de algo ou alguém que está por perto, como alguém da mesma família.

A abordagem da "tia" no Grupo era feita frequentemente de forma individualizada ${ }^{33}$, uma vez que muitas evitavam assumir publicamente serem HIVpositivas ou terem AIDS. Isso se devia ao fato de temerem a exploração do fato por parte de outras travestis, no cotidiano da prostituição. Várias delas relataram que era algo comum que uma travesti acusasse outra de ter AIDS como forma de assustar seus clientes e tomá-los para si. Em situações de conflito, ter AIDS era um dos atributos frequentemente visados nas brigas e discussões, ao lado de referências à pouca feminilidade do corpo e ao pouco rendimento obtido com a prostituição. Neste caso, o termo mais utilizado era o popular "aidética", mostrando uma clara tendência à desqualificação daquela à qual o adjetivo era direcionado.

O impacto da "tia" se fazia sentir em várias esferas da vida das travestis estudadas. A principal, obviamente, era a da saúde. Pude acompanhar o sofrimento físico de muitas delas, orientando-as e encaminhando-as para tratamento adequado, uma vez que a instituição em que ocorria o Grupo tinha muito pouco a oferecer neste sentido. Uma das orientações constantemente repetida era a de não se interromper o tratamento com anti-retrovirais, algo muito comum entre elas e motivado na maior parte das vezes pelas constantes "temporadas" passadas em outras cidades.

Outro ponto onde o impacto da "tia" se fazia sentir de forma pronunciada era em relação às transformações corpóreas dela advinda. Se o corpo almejado pelas travestis era o da "mulher fatal", construído por hormônios e silicone, a "tia" em certa medida desconstruía este corpo, devido ao frequente emagrecimento que gera, levando à perda de formas voluptuosas tidas como tipicamente femininas e cultuadas por elas. $O$ mesmo ocorria em relação à queda de cabelos, outro símbolo da feminilidade para as

\footnotetext{
${ }^{33}$ Era comum que algumas chegassem antes do horário ou ficassem esperando até as demais irem embora para um conversa "em particular" comigo.
} 
mesmas. Em um certo sentido, pode-se dizer que a "tia" era percebida como algo que "re-masculinizava" o corpo:

\footnotetext{
P. me procurou depois do encontro para pedir um encaminhamento para um outro local para tratamento de AIDS, pois não estava satisfeita com seu médico do (...) Disse que estava só "pele e osso", que perdeu seu "corpão", que os hormônios "foram embora".
}

É importante, também, ressaltar o impacto da "tia" na auto-imagem das travestis. Uma outra expressão bastante utilizada por elas mostra isso com clareza: "ter o sangue sujo", utilizada como referência ao fato de alguém ser HIV-positivo. Como mostra Duarte (1986), o sangue traz frequentemente em suas representações uma dimensão moral, como, por exemplo, na frequente expressão "sangue ruim", que carrega consigo a idéia de que os aspectos morais negativos seriam hereditários. Da mesma forma, a sujeira, para Douglas (1991) é frequentemente utilizada em diferentes sistemas culturais como critério de classificação entre o que está dentro e fora da ordem das coisas, o que implica no fato de os esforços para a limpeza serem também esforços para organizar o ambiente. A expressão "sangue sujo" parece implicar, assim, não somente o sangue contaminado pelo HIV, mas também uma "sujeira" moral em quem o tem, impossível de ser "limpa". Por isso, revelar que se tem o "sangue sujo" é algo envolvido em uma atmosfera de vergonha e culpa. Como pude presenciar várias vezes, esta revelação assumia um tom confessional, que se assemelhava à admissão de se ter cometido um "pecado" ou alguma coisa errada. É uma expressão que sem dúvida transparecia uma auto-culpabilização intensa em relação ao fato da travesti se saber portadora do HIV.

Em estudo sobre travestis argentinas, Barreda e Isnardi (sd) fazem uma observação que considero pertinente também em relação às travestis pesquisadas: estas pareciam conceber a AIDS como um "destino", que não pode ser mudado. Para as mesmas autoras, a idéia de prevenção requer um pensamento antecipatório, a visualização do futuro, o que acaba sendo prejudicado em um segmento da população que tem como prioridade a preservação imediata de sua integridade física, constantemente ameaçada pela violência social. Frente a essa dificuldade, a abordagem da prevenção à AIDS no Grupo - não somente a relacionada à infecção, 
mas também a relacionada à re-infecção - era feita a partir das estratégias de redução de danos já citadas, uma vez que ficou claro para mim, após algum tempo de intervenção, que seria impossível que elas adotassem plenamente os cuidados relacionados ao sexo seguro. O uso de preservativos, por exemplo, era comum apenas nas relações com os clientes, e não nas relações com "maridos" e "vícios" ${ }^{34}$, algo constantemente discutido nos encontros quanto a suas implicações.

Um outro aspecto que considero interessante ressaltar em relação ao tema diz respeito à forma como certos discursos médicos eram por elas interiorizados. Diferentemente da Argentina, onde, segundo Barreda e Isnardi (sd) havia uma invisibilidade das travestis nas políticas públicas de saúde, por conta da negação de sua existência enquanto "outro", por sua "sexualidade errática e improdutiva", no Brasil, segundo me parece, as travestis foram contempladas com programas específicos de prevenção, bastante criativos $^{35}$. Um dos elementos mais destacados nestes programas refere-se à tentativa de se explicar o conceito de "carga viral", na expectativa de que as travestis que já são soropositivas se engajem mais fortemente na prevenção da AIDS. Trata-se de explicar a elas que uma re-infecção pelo HIV gera um aumento da carga viral, o que pode contribuir para a doença se manifestar mais rapidamente e com maior intensidade. Tal conceito, porém, entre várias das travestis investigadas, era interpretado de forma a se pensar que a "carga viral" era algo constante, o que levava à consequência imaginada de que era algo passível de diminuição caso mantivessem relações sexuais sem uso de preservativo. Da mesma forma que o hormônio feminino, como vimos anteriormente, o vírus da AIDS poderia ser "expulso" do corpo pela via da ejaculação.

\footnotetext{
34. Observação semelhante é feita por Kulick (1998, p 29)

35 Entre outros recursos, desde o início dos anos 90, o poder público, em, diferentes locais do país, financiou cartilhas específicas para o segmento travesti, muitas realizadas com a colaboração das mesmas. Da mesma forma, o Ministério da Saúde financiou eventos específicos para esta população, os principais dos quais foram os diversos ENTLAIDS - sigla que a princípio significou "Encontro Nacional de Travestis e Liberados que atuam na prevenção de DST/AIDS” e modificou-se posteriormente para "Encontro Nacional das Travestis, Transexuais e Transgêneros que Atuam na Prevenção da AIDS"
} 


\section{TRABALHO}

Como vimos no primeiro capítulo deste estudo, a configuração das travestis enquanto grupo social, a partir de meados da década de 70, é inseparável da prostituição. Embora nem sempre sejam profissionais do sexo, a elevadíssima frequência em que isto ocorre acaba por tornar a prostituição um elemento definidor da identidade travesti. Faz sentido, portanto, relacionar suas vivências com as de outros profissionais do sexo, como prostitutas e michês. Da mesma forma, é importante que se considere os diferentes segmentos de prostituição de acordo com a renda, uma vez que isto determina formas diversas de inserção social.

Antes, contudo, é necessário que algumas ponderações sejam feitas em relação à atividade da prostituição. Isto implica em refletir sobre um triplo cuidado necessário ao se abordar o tema: considerá-la como historicamente contingente, como tendo limites imprecisos e como algo que não define os sujeitos que a praticam em sua totalidade vivencial, cuidados estes que buscaremos em nosso estudo.

Uma das observações importantes de ser levada a cabo em relação à prostituição é em relação às circunstâncias históricas a ela associadas. Isso significa afirmar que a prática da prostituição está sempre relacionada a um contexto social maior, assumindo especificidades decorrentes das particularidades deste contexto. Como mostra Rago (1991), em relação à história da prostituição no Brasil, o próprio termo "prostituição" é apropriado por um regime discursivo médico-jurídico, não podendo "ser projetado retroativamente para nomear práticas de comercialização sexual feminina em outras formações sociais, sem realizar um aplainamento violento da singularidade dos acontecimentos" ( $p$ 23). No contexto do Brasil do século XIX e início do século $X X$, é relevante, por exemplo, a forma como os poderes policiais se 
combinam ás estratégias sanitaristas a serviço do controle das prostitutas oriundas de segmentos populares, como mostram Rago (1991) e Engel (1988).

Outra consideração importante a respeito da prostituição é em relação aos limites das práticas que o termo define. Piscitelli (2005) considera que as definições de prostituição, ao se concentrarem na idéia de uma prática que necessariamente assume a forma de um contrato explícito de intercâmbio entre sexo e dinheiro, deixam de lado outros tipos de interação onde tal troca está implícita, como na situação do "velho que ajuda" economicamente jovens das camadas populares, que não são consideradas prostitutas. Tal modalidade de relação onde um parceiro, mais velho, "ajuda" financeiramente o outro, mais jovem, é comum também nos meios homoeróticos brasileiros, como mostra Perlongher (1987a).

Como última consideração, compreende-se aqui a importância de fugir das armadilhas essencialistas que reduzem a figura da prostituta a sua ocupação, caracterizando-a como uma "espécie" diferente de ser humano, herança da concepção médico-higienista do século XIX e início do XX, o que leva a uma ontologização de uma prática social específica, como mostra Welzer-Lang (1994, p 67). Essa representação ocorre também em função do fato de prostitutas em diversos locais do mundo formarem grupos socialmente isolados, ao contrário do que ocorre com outras ocupações, de acordo com Rubin (1999).

Feitas estas ponderações, é importante considerar que o momento histórico em que as travestis apareceram como grupo social distinto, tendo a prostituição como ocupação principal - anos 70 - corresponde a um período, que se estende aos dias de hoje, em que a prostituição enquanto prática autônoma não é considerada ilegal. Não há, por outro lado, o reconhecimento da prostituição como prática profissional, o que faz com que subterfúgios legais possam ser usados como instrumentos de repressão à prostituição, tanto masculina como feminina, como veremos mais adiante.

Em meados da década de 80, com a abertura política, movimentos associativos começaram no Brasil, ecoando propostas similares em outros países ${ }^{1}$, a exigir o

\footnotetext{
1 Trata-se, de acordo com Welzer-Lang (1994) de uma reivindicação por parte das prostitutas em serem “sujeitos” e não “objetos”(p 19)
} 
reconhecimento da prostituição como uma forma de trabalho, compreendendo este como um passo importante para a garantia de alguns direitos fundamentais. Essa discussão em relação à prostituição feminina ganhou força no Brasil com o surgimento de lideranças que defendiam a legalização da prostituição (Moraes, 1996). Mais recentemente algumas associações de travestis, principalmente no Rio de Janeiro e em Salvador passaram a defender posição parecida ${ }^{2}$. Tais lutas se aprofundaram nas décadas seguintes e ainda são fortemente atuantes no dias de hoje ${ }^{3}$.

O termo "profissional do sexo" passou a ser usado como referência ao profissional masculino ou feminino que exerce a atividade de prostituição, sendo popularizado tanto pelos movimentos associativos como pelos estudos acadêmicos a respeito da prostituição. Embora esta não seja legalizada, a ocupação de "profissionais do sexo" foi recentemente reconhecida pela Classificação Brasileira de Ocupações do Ministério do Trabalho, o que reflete o embate atual em relação ao status jurídico da prostituição. Nesta Classificação, são considerados como sinônimos de profissional do sexo:

Garota de programa, Garoto de programa, Meretriz, Messalina, Michê, Mulher da vida, Prostituta, Puta, Quenga, Rapariga, Trabalhador do sexo, Transexual (profissionais do sexo), Travesti (profissionais do sexo)

As atividades de tais profissionais são assim detalhadas:

"Batalham programas sexuais em locais privados, vias públicas e garimpos; atendem e acompanham clientes homens e mulheres, de orientações sexuais diversas; administram orçamentos individuais e familiares; promovem a organização da categoria. Realizam ações educativas no campo da sexualidade; propagandeiam os serviços prestados. As atividades são exercidas seguindo normas e procedimentos que minimizam as vulnerabilidades da profissão.”

Fonte: Classificação Brasileira de Ocupações do Ministério do Trabalho

\footnotetext{
${ }^{2}$ Duas das Associações de travestis mais antigas e atuantes no Brasil são a ATRAS, de Salvador e a ASTRAL, do Rio de Janeiro

${ }^{3}$ Atualmente encontra-se em tramitação no Congresso Nacional o Projeto de Lei 98/2003, que busca legalizar a prostituição.
} 
Em uma breve análise destas descrições, fica clara a unificação das diferentes modalidades de prostituição, como as dos michês, prostitutas e travestis, em uma única categoria. Da mesma forma, os profissionais do sexo nelas aparecem como pessoas necessariamente conscientes, em termos políticos, uma vez que "promovem a organização da categoria", e em termos sexuais, já que "realizam ações educativas no campo da sexualidade' e tem suas atividades exercidas "seguindo normas e procedimentos que minimizam as vulnerabilidades da profissão". Seguindo a consideração de Rago (1991) a respeito do fato da prostituição ser historicamente contingente, o que parece estar em jogo aqui é o surgimento de uma nova identidade na prostituição, sob a figura do "profissional do sexo", estabelecida como resultado dos movimentos associativos e das políticas de prevenção e de promoção de saúde pósAIDS.

No caso das travestis aqui pesquisadas, a discussão da prática da prostituição como um exercício profissional era constantemente destacada, tanto pelas travestis como por mim, na figura de coordenador do Grupo, que sempre me coloquei nele de forma favorável ao seu reconhecimento profissional. A incorporação dessa nova identidade relacionada à prostituição, a de "profissional do sexo", era, contudo incipiente, como veremos adiante.

Outro ponto importante a ser destacado em relação ao Grupo era, como vimos, o fato dele concentrar travestis de baixo rendimento com a prostituição, vindas em sua grande maioria dos "pontos" das regiões norte e central da cidade de São Paulo que concentravam tal segmento da população travesti. Algumas de alta renda chegaram a frequentá-lo em alguns poucos encontros, mas não aderiram ao mesmo:

S. veio novamente, extremamente bem-vestida. Saiu por duas vezes da sala para atender o celular [acessório que as travestis do Grupo em sua grande maioria não utilizavam]. Pediu desculpas, dizendo que era um cliente. Observei alguns olhares atravessados de travestis para ela, que praticamente não interagiu com as demais.

A prostituição de rua ou "trottoir" era a modalidade fortemente predominante entre elas, daí ser objeto de consideração mais extensa. 


\section{O "Trottoir"}

Em relação aos espaços ocupados pelas travestis para trabalhar, os chamados "pontos" de prostituição, há algumas considerações importantes a serem feitas. Em um dos encontros, no início de 2003, procurei traçar, com o auxílio das mesmas, um mapa dos principais pontos de prostituição travesti em São Paulo. Foram referidos os seguintes ${ }^{4}$ :

- imediações da Av Amaral Gurgel, Rego Freitas e adjacências (Vila Buarque)

- "boca do Lixo", cinemas da região da Av Ipiranga e Mercado Municipal (Santa Efigênia)

- região da Av Cruzeiro do Sul (Carandiru)

- região da R, Voluntários da Pátria (Santana)

- região do Jóquei e Cidade Universitária (Butantã)

- região da Av Indianápolis (Planalto Paulista)

- região da Av. Marquês de São Vicente (Barra Funda)

- região da R. Juntas Provisórias (Ipiranga)

- parque do Carmo (Itaquera)

No estudo de Perlongher (1987a) sobre michês em São Paulo, na década de 80, que aborda também secundariamente as travestis, a prostituição homossexual em São Paulo é descrita como algo que obedecia a uma territorialização da homossexualidade em São Paulo, ou seja, como algo que ocorria em regiões onde havia grande frequência de homossexuais. Uma análise dos pontos de prostituição travesti descritos,

\footnotetext{
${ }^{4}$ Estes dados são citados aqui para mostrar o quanto tal modalidade de prostituição está disseminada por todas as regiões de São Paulo e não tem a pretensão de ser um retrato fiel desta realidade. Além do fato dos pontos de prostituição travesti estarem em constante mobilidade, por causa, na maior parte das vezes, da violência policial e de clientes, há certamente outras regiões importantes que não foram citadas por elas, como, por exemplo, as da Avenida São Miguel, na Zona Leste e a do Parque do Ibirapuera (Autorama) na Zona Sul.
} 
porém, mostra que tal associação não se sustenta mais: há um claro rompimento desta com os limites da territorialização homossexual em São Paulo.

Diversos autores, como Pascual (1995), Trindade (2004), Simões e França (2005) e Antunes (2005) apontam que há atualmente um certo contraponto entre duas regiões em São Paulo - Centro e Jardins - que congregam boa parte dos locais de lazer e, em muitos casos, de moradia de homossexuais em São Paulo, havendo um predomínio de segmentos de renda mais altos nos Jardins em relação ao Centro. Considerando, porém, as principais regiões de concentração travesti em São Paulo descritas anteriormente, podemos perceber que apenas os dois primeiros estão inseridos nestes territórios ou, ao menos, próximos a eles. Os demais encontram-se fora e, em alguns casos, bastante distantes dos mesmos.

Uma das possíveis razões para explicar tal fato refere-se à maneira como se formam os pontos de prostituição de travestis. Se os mais antigos, justamente aqueles que se situam nos territórios de maior predominância homossexual, desenvolveram-se em regiões onde havia uma confluência da prostituição feminina e de forte presença de indivíduos com preferências homoeróticas (Santa Efigênia e Vila Buarque) ${ }^{5}$, os demais, mais recentes, parecem corresponder a uma ocupação de pontos de prostituição tradicionalmente femininos ${ }^{6}$. Isso ocorreu, segundo relatos das próprias travestis investigadas, nas regiões do Jóquei e Cidade Universitária e nas imediações das avenidas Indianápolis e Cruzeiro do Sul e R. Voluntários da Pátria ${ }^{7}$. Se em algumas destas regiões há ainda uma convivência, ainda que tensa com as prostitutas, em outros estas foram expulsas pelas travestis, muitas vezes de forma violenta ${ }^{8}$.

\footnotetext{
${ }^{5}$ Parker (2002) cita a sobreposição das regiões ocupadas por homossexuais e prostitutas como algo comum nos grandes centros brasileiros (p. 102).

${ }^{6}$ Perlongher (1987a) cita uma confluência de prostitutas e travestis nas mesmas ruas da região da Vila Buarque, em São Paulo, nos anos 80, mas com as prostitutas em desvantagem nos conflitos territoriais, o que implica em ocupar os locais com menor "movimento" (p 87)

${ }^{7}$ Não obtive informações sobre os demais pontos, situados na Barra Funda, Ipiranga e Itaquera

${ }^{8}$ Gaspar (1985) ressalta que o mesmo processo ocorreu no Rio de Janeiro, na região da Lapa e na Av. Nossa Senhora de Copacabana (p. 18).
} 
As razões que explicam a lógica da disseminação de travestis pela apropriação dos territórios femininos são obscuras. Se estudos sobre os clientes da prostituição feminina são poucos ${ }^{9}$, os dos clientes das travestis são praticamente inexistentes ${ }^{10}$, pois é uma população muito difícil de ser abordada, dado o estigma que envolve a prática de se ter relacionamento sexual com as mesmas. Trevisan (2000) considera a dispersão delas por bairros de classe média como uma consequência da repressão policial na região central de São Paulo, no final da década de 70 e início da de 80 (p. 420). Embora este possa ter sido de fato um fator importante, é necessário, contudo, considerar também a dinâmica própria à prostituição. É possível pensar que talvez muitas travestis tenham passado a se deslocar pela cidade à procura de outros clientes e/ou que seus clientes tradicionais tenham começado a frequentar menos as regiões centrais da cidade, acompanhando o movimento de crescente segmentação geográfica de classes pelo qual passa a sociedade brasileira. Pode-se supor, também, que uma parcela, ainda que pequena, dos clientes das prostitutas busquem travestis de forma eventual para relacionamento sexual, o que explicaria a entrada destas nesses pontos. Uma vez consolidados, passariam a atrair apenas clientes desejosos de relacionamento com travestis, após a expulsão das prostitutas por parte delas.

Em relação ao local de moradia, era comum que as travestis pesquisadas buscassem morar em locais próximo aos pontos de prostituição, embora isto não ocorresse na totalidade dos casos. Entre os motivos apresentados por elas para essa associação entre local de trabalho e de moradia estavam os relacionados às facilidades logísticas e à evitação do preconceito. Em relação a este último fato, o que parecia ocorrer pela descrição das mesmas era a criação de um certo espaço de tolerância por parte de comerciantes e, às vezes, até mesmo por parte de alguns moradores, em relação a sua presença em uma determinada área. Após algum tempo de convivência mais tensa, a vizinhança "se acostumava" com sua ocupação de determinados "pontos", o que certamente não ocorria na totalidade dos mesmos, uma vez que conflitos entre travestis e moradores são comuns em diversas regiões de São Paulo

\footnotetext{
${ }^{9}$ Ver a esse respeito, o trabalho de Souza (2000)

${ }^{10}$ Há apenas um estudo sobre estes (Pelúcio, 2005a), que será comentado mais adiante.
} 
Algumas travestis que participavam dos encontros também se utilizavam de cinemas como local de prostituição. Os cinemas pornográficos das grandes cidades são considerados importantes locais de socialização homossexual por Parker (2002), especialmente no que diz respeito à busca por parceiros sexuais, geralmente anônimos (p. 74). Os estudos sobre cinemas de "pegação" realizados por Terto Jr (1989), no Rio de Janeiro, e por Vale (2000), em Fortaleza, mostram realidades parecidas em termos da configuração de um cenário orgiástico nestes cinemas, com intensa atividade sexual ocorrendo de várias formas. Nestes dois estudos as travestis são referidas como personagens importantes. Ambos descrevem a busca ativa e incessante das mesmas por clientes nos cinemas analisados (Terto Jr, 1989, p. 62 ; Vale, 2000, 117), ao mesmo tempo que observam as mesmas participando, em alguns momentos de relações sexuais sem cobrar, principalmente com garotos jovens e atléticos, e das próprias orgias (Terto Jr, 1989, p 60 e Vale, 2000, p 123).

As travestis do Grupo que se prostituíam nos cinemas o faziam na maior parte das vezes como algo alternativo à prostituição de rua ${ }^{11}$. Nestes, buscavam seus clientes entre os frequentadores, realizando o "programa" geralmente no banheiro do cinema ou nas últimas fileiras de poltronas. Os "programas" eram descritos por elas como mais curtos e mais baratos, havendo um rodízio maior de clientes em comparação com os típicos da prostituição de rua. A grande desvantagem dessa modalidade, apontada por muitas, referia-se a uma "diária" que muitos cinemas cobravam delas, o que fazia que elas precisassem trabalhar muito mais para conseguir ter um lucro com a atividade. Por outro lado, a segurança no exercício profissional dentro dos cinemas era considerada bem maior do que nos espaços públicos, o que fazia com que estes fossem utilizados como alternativa em períodos onde havia maior risco nas ruas.

Embora fosse um local de trabalho escolhido por algumas, a prostituição nos cinemas pornôs era recusada por outras, que diziam se sentir mal em trabalhar em locais "fechados", como é o caso dos cinemas. Referiam-se a rua como um espaço de liberdade. Podemos relacionar tais observações ao estudo de Freitas (1985) sobre a

\footnotetext{
11 Vale(2000) ressalta a presença de travestis que trabalhavam somente no cinema que estudou e de outras que o frequentavam ocasionalmente, trabalhando também nas ruas.
} 
prostituição feminina em Belo Horizonte. Este autor considera que há características importantes que diferenciam a prostituição de rua, em comparação com as modalidades exercidas em locais fechados, como nos bordéis, uma vez que o bordel cria uma fronteira física entre um lado de "dentro" e um de "fora", segregando fisicamente as prostitutas que recruta e reforçando nas mesmas um sentimento de exclusão ( $p$ 49). No trottoir, pelo fato de não haver uma fronteira física definida, não se cria uma segregação espacial imediata, uma vez que outros personagens, além dos clientes, circulam por estes lugares, o que permite outros tipos de interação, reduzindo-se o sentimento de exclusão referido. Consideramos que tal interpretação é viável para explicar a recusa de muitas travestis investigadas em relação à prostituição em cinemas.

\section{A "puta"}

Um vez que a prostituição é uma posição histórica e culturalmente instituída como feminina ${ }^{12}$ (Arent, 1999), é possível considerar que a apropriação desse campo de trabalho levava as travestis pesquisadas à incorporação de outra identidade social em sua "colcha de retalhos" identitária: a da "puta". Se algumas se identificavam como "profissionais do sexo", o que implica em uma ressignificação do sentido historicamente atribuído à prostituição, relacionado à valorização desta enquanto trabalho, a maior parte parecia se apropriar de uma concepção imaginária do que é "ser puta" típica da cultura de gêneros tradicional no Brasil ${ }^{13}$.

Analisando a cultura sexual brasileira tradicional, Parker (1992), conceitua a "puta" como uma figura que desempenha papel importante na construção do gênero da vida diária. Ao mesmo tempo em que serve de veículo de confirmação da masculinidade para seus clientes, a puta "é vista como agente de destruição, como a mulher que 'come', que desvia homens, famílias, tudo que encontra no seu caminho" ( $p$. 85). Entre os estereótipos associados à "puta" no Brasil, descritos por Moraes (1996),

12 É importante considerar, também, que, embora seja um ethos feminino, a prostituição é submetida a normas ditadas por um domínio masculino, como afirma Moraes (1996, p. 155)

${ }^{13}$ Kulick (1998) afirma que a "puta” é a representação de mulher mais comum entre travestis (p 235) 
há alguns que parecem ter sido incorporados pelas travestis estudadas: "(...) Carregam marcas que as identificam: 'roupas extravagantes e indecentes, acessórios aberrantes', expressam-se através de posturas e gestos que são considerados ousados e imorais" (p. 33-4). A impressão que formei no contato semanal com essas travestis foi semelhante à descrita por Welzer-Lang (1994, p 131) a respeito das transgêneros que se prostituem em Lyon, na França: a de que elas pareciam corresponder ao estereótipo da prostitutas muito mais do que as próprias mulheres que se prostituem.

A incorporação da imagem da "puta" pelas travestis estudadas pode ser interpretada como uma necessidade de corresponder às fantasias de seus clientes. Mas certamente esse não é o único fator, uma vez que não pode ser desprezado aqui o contato próximo que as mesmas mantinham com várias mulheres prostitutas ${ }^{14}$. $\mathrm{O}$ relacionamento das travestis com estas, embora muitas vezes envolvesse tensão e violência, como vimos, não pode ser descrito sempre nestes termos. No Grupo, por exemplo, algumas mulheres prostitutas participavam ocasionalmente dos encontros e pareciam conviver de forma relativamente harmônica com as travestis, compartilhando inclusive pontos de prostituição contíguos:

\begin{abstract}
Hoje compareceu uma integrante nova, T. No meio do encontro ela começou a dar algumas opiniões e eu comecei a achar que ela era mulher. Não resisti e perguntei. Ela disse: "Claro que sou mulher!”. Pensei que só eu tinha me enganado, mas outra travesti disse que ela também tinha achado que ela era "bicha". T. contou que ela vivia tanto no meio das travestis que acabou "pegando o jeito delas”. Ela e mais duas mulheres dividem uma casa na região da [avenida da zona norte] e estão lá há cinco anos. Contaram que faziam programas junto com as meninas da P. [referência às travestis que moravam na pensão da cafetina P.]
\end{abstract}

A assunção da figura da prostituta pelas travesti pesquisadas pode ser vista também como guiada pela necessidade de sentirem desejadas, o que thes daria uma afirmação da feminilidade que buscam, idéia defendida por Calligaris (2004) a respeito das travestis em geral. A prostituição apareceria assim não somente como motivada pela necessidade econômica, mas também como um espaço de afirmação da

\footnotetext{
14 Embora tenha trabalhado apenas ocasionalmente com prostitutas, no próprio Grupo e em outros contextos profissionais, tive contato constante com profissionais que trabalhavam com este segmento. A troca de informações sempre me sugeriu um grande número de semelhanças entre travestis e prostitutas.
} 
feminilidade. Pode, portanto, conforme propõe Kulick (1998, p 136, 184) e Benedetti (2000, 114), ser vista como um campo de experiências prazerosas para as travestis ${ }^{15}$, certamente mais do que entre a maior parte das prostitutas mulheres:

R. [uma das pouquíssimas travestis do Grupo que não se prostituíam regularmente e que tinha um pequeno salão de cabeleireira, adquirido após um período vivendo na Europa] disse que tinha um "vicio" em ir para a Avenida, mesmo não precisando mais do dinheiro. Contou que adorava ver os carros pararem, buzinarem para ela, que achava aquilo "o máximo".

Isso explica também o desprezo delas voltado aos clientes que buscavam por relações sexuais passivas nos "programas", uma vez que, embora isso garantisse a satisfação das necessidades financeiras, não realizava as da ordem de serem desejadas como "mulheres". O "programa", contudo, quando realizado com um cliente que buscava por sexo "ativo" e que as pagava satisfatoriamente, era visto como algo agradável. De forma semelhante, a falta de clientes era motivo de queixa da parte delas, não somente pelos problemas financeiros que gerava, como também por não proporcionar seu reconhecimento como "mulheres" desejáveis. Neste sentido, Kulick (1998) afirma que a prostituição é o único contexto onde a travesti desenvolve a autoestima, podendo ser elogiada, reconhecida, "cantada" e, ao mesmo tempo, ganhar dinheiro (p.189-190). Tal afirmação, contudo, tem que ser relativizada em função da "decadência" no mercado sexual, o que se configurava como uma fonte de sofrimento intensa para as travestis investigadas, especialmente quando não conseguiam ganhar o suficiente para manter seu modo de vida.

A vivência da prostituição como algo associado ao prazer tinha implicações importantes na constituição subjetiva das travestis estudadas. Diferentemente do que é comum entre prostitutas mulheres, conforme mostram os estudos de Gaspar(1985) e Castro (1993), não havia a necessidade entre elas de configurar uma "vida dupla", escondendo da família a atividade profissional exercida - o que em parte se devia ao

\footnotetext{
${ }^{15} \mathrm{O}$ prazer em se sentir desejado, em conquistar e em ser pago é também citado por Welzer-Lang (1994) entre transgêneros que se prostituem na França, para quem esta modalidade de prostituição está mais associada ao prazer e à festa do que a feminina (p 76-7). .
} 
fato de grande parte delas não ter contato com a mesma. Gaspar (1985) mostra, entre as prostitutas cariocas que estudou, a necessidade destas de construir limites na interação com os clientes, como na restrição ao beijo na boca, ao orgasmo e ao ato de dormir junto com os mesmos. Essa evitação do envolvimento emocional com eles, segundo a mesma autora, era associada a uma cisão entre o "self" e o papel profissional das prostitutas (p. 116-9). Tais limites eram praticamente inexistentes entre as travestis do Grupo, o que mostra que estas incorporavam plenamente a identidade da prostituta, não buscando se dissociar da mesma.

Apesar de algumas diferenças existentes, contudo, as semelhanças entre os universos vivenciais de travestis e prostitutas de baixa renda eram inúmeras e se mostrava principalmente pela dinâmica intrínseca ao exercício profissional, discussão que, por sua complexidade, merece um item específico.

\section{Travestis como trabalhadoras informais autônomas}

O fato da prostituição ser uma ocupação não-regulamentada no Brasil coloca as travestis pesquisadas em uma categoria sociológica maior, que é a dos trabalhadores informais. Da mesma forma, em razão da cafetinagem típica da prostituição feminina ser praticamente inexistente entre elas, podem ser localizadas no setor autônomo da economia. Singer (1979) define este como "aquele que é composto por empreendimentos individuais cujo produto se destina ao mercado", englobando, entre outros, o segmento denominado de "lúmpen" pelos marxistas, constituído por mendigos, prostitutas e delinquentes ( p. 79). O setor autônomo é constituído, para este autor, por atividades de nível de produtividade precário, com raras exceções, e tende a "absorver a força de trabalho excedente, ou seja, aquela que se encontra na economia de mercado, porém não consegue empregar-se na economia capitalista ou nas atividades governamentais" ( $p$ 80). Por este motivo, tem uma relação inversamente proporcional com a economia capitalista, uma vez que se retrai quando esta está em expansão e tem seu contingente ampliado quando a mesma está em crise. 
Paralelamente à demanda insuficiente pela sua força de trabalho, os “desempregados disfarçados", para Singer (1979), se deparam com obstáculos sociais a sua inserção na divisão social capitalista do trabalho. Entre estes, o autor cita dois que consideramos relevantes em relação às travestis estudadas: a "insuficiente preparação técnica e psicológica para se incorporar às atividades rotinizadas da economia capitalista" e os preconceitos de raça, sexo, idade, etc, que levam à "recusa por parte das empresas de engajar negros mulheres e pessoas acima de certa idade" ( $p$ 84). Como vimos anteriormente, o pouco preparo escolar e o preconceito social direcionado aos homossexuais efeminados eram fatores determinantes para a entrada destas na prostituição.

Pelo fato de se colocarem como trabalhadoras informais autônomas e de ocuparem espaços públicos em sua atividades, abordando os clientes em ruas, praças e avenidas, as travestis pesquisadas aproximavam-se de outras categorias profissionais, como a dos ambulantes ou camelôs. Explorar os aspectos comuns a estes segmentos, portanto, é relevante, uma vez que isso nos permite perceber que um número significativo de traços apresentados por elas não tinha sua origem, especificamente, em determinantes relacionados ao gênero e nem mesmo à prostituição por si só, mas sim à forma como se dava sua inserção no mercado profissional.

Ramires (2000), em estudo de campo com camelôs na cidade de São Paulo, aponta algumas características deste grupo:

(1) - a utilização da rua e a falta de um espaço privado que defina o exercício da profissão gera uma competição pela utilização do espaço público entre os camelôs. Nasce aí a disputa pelos melhores "pontos" de venda. A falta de legalização da prática acaba por gerar outros tipos de atividades ilegais relacionadas à atividade profissional, como o pagamento pelos "pontos" de melhor movimento.

(2) - a utilização do espaço público gera resistência de comerciantes, que os acusam de os inviabilizar economicamente em função dos baixos preços cobrados, e de moradores, que se queixam do lixo jogado nas ruas. A pressão destes gera muitas vezes a ação policial de "limpeza" da área e expulsão dos camelôs. 
(3) - a falta de comprovação de renda leva a um encarecimento do crédito e do aluguel. Isso acaba por gerar relações de exploração entre os próprios camelôs, como a sublocação de quartos a preços muito superiores ao mercado.

(4) - a falta de perspectiva profissional e endividamento constante levam muitos camelôs ao ensejo de ganhos rápidos, o que muitas vezes acaba por conduzi-los a outra atividades ilegais, como a receptação e venda de mercadorias ilícitas.

(5) - a competição direta com os outros camelôs gera muitas vezes uma "guerra de preços" que contribui para o processo de pauperização entre eles. O aumento da rivalidade entre eles acaba por gerar dificuldade de articular os interesses comuns, o que fica patente na dificuldade de criação e funcionamento das associações de camelôs.

Tais características podem ser relacionadas de forma muito próxima àquelas apresentadas pelas travestis aqui investigadas:

\section{(1) - a competição pelo espaço público.}

Ter um bom "ponto" de prostituição era algo considerado fundamental entre elas. Defendê-lo contra "invasões" de outras travestis era também uma necessidade constante. As mais velhas e as que trabalhavam há mais tempo no local reivindicavam para si a primazia de ocupar os melhores "pontos". O único episódio de agressão física que presenciei durante a duração do Grupo ocorreu exatamente por este motivo:

Hoje ocorreu uma briga violenta. Em um determinado momento D. se virou para T., que estava do outro lado da sala e começou a gritar, dizendo que já tinha dito a ela que não era mais para ela descer do lado da rua em que ela (D.) ficava. Ela se levantou e foi muito rápido para cima de T., que estava do meu lado, tirou o seu sapato e bateu com o salto em sua testa, fazendo esguichar sangue pela sala, inclusive em mim. Imediatamente eu saí de perto, com medo de ser agredido e de T. ser soropositiva. As outras travestis seguraram D. e saí para avisar o [enfermeiro da instituição] para fazer o curativo em T., mas esta não quis esperar e foi embora antes. Na discussão posterior D. continuava muito alterada dizendo que "sabia que ia pegar ela” no Grupo. As outras travestis falaram que ela errou ao agredi-la ali, mas pareceram achar totalmente justificável a agressão em si. 
Outra similaridade das travestis estudadas com os camelôs refere-se ao aluguel de "pontos". A cobrança de alguma "taxa" era citada como uma estratégia utilizada às vezes pelas mais velhas em relação às mais novas, recém-chegadas a São Paulo e/ou recém-ingressas na prostituição. Tal cobrança parecia se referir a necessidade das mais jovens compensarem as mais velhas por uma possível queda de seus rendimentos, uma vez que atrairiam mais clientes, prejudicando-as financeiramente ${ }^{16}$. Embora acontecesse nessa situação, o pagamento de diárias e/ou taxas de proteção não era referido como prática que se sustentava por longos períodos entre elas. As mais jovens logo se revoltavam contra as taxas que lhes eram impostas, mudando de ponto de prostituição ou enfrentando as mais velhas, tendo como garantia os novos laços de sociabilidade feitos com outras travestis ou a proteção de uma "cafetina".

O termo "cafetina", utilizado, como vimos, em referência à travesti mais velha, dona de pensão específica para travestis, diferia do "cafetão" ou "cafetina" típicos da prostituição feminina, em função de implicar em uma relação de moradia, mais do que de proteção, ainda que esta última por vezes estivesse presente. Também se configurava como um vínculo escolhido pela travesti, e não como uma relação imposta, o que por vezes ocorre na prostituição feminina. A forma de dominação exercida pelo cafetão típico da prostituição feminina, contudo, às vezes aparecia também entre as travestis pesquisadas e era objeto de reações violentas:

Hoje no Grupo vieram só três travestis. Estavam assustadas com algumas brigas que estavam ocorrendo na região da [...]. Pelo que contaram, C. [travesti muito presente no Grupo antes, mas que estava afastada] voltou de [capital nordestina] com seu irmão e cinco outras travestis. Estas se instalaram na região e o irmão de C. começou a cafetiná-las. L. e D. [duas travestis mais velhas, muito atuantes no Grupo] não gostaram dessa atitude e ameaçaram C. Em um conflito entre as duas. D. esfaqueou C. O irmão de C. foi atrás de D. e atirou nela, ferindo-a na região da virilha.

Sobre os conflitos ocorridos na semana retrasada, $\mathrm{P}$ contou que $\mathrm{D}$. estava melhor, mas resolveu passar “um tempo em sua terra até a poeira abaixar”. Sob a pressão de L e de outras travestis, C e seu irmão concordaram que as travestis novatas passassem a fazer ponto em

\footnotetext{
${ }^{16}$ A rivalidade entre travestis mais jovens e mais velhas é também referida por Ferreira (2003, p 90-1) e
} Pelúcio (2005b). 
outra região. M. comentou no Grupo que "logo, logo, essas bichas vão dar problema”, referindo-se ao fato que elas não iriam tolerar ser cafetinadas por muito tempo.

\section{(2) - a reclamação de comerciantes e moradores.}

Segundo as travestis investigadas, o objeto de queixa mais comum dos moradores e comerciantes era relativo ao fato delas muitas vezes andarem semi-nuas e de mostrarem os genitais em público. A exibição ostensiva da nudez era referida por elas como uma necessidade para a conquista de clientes. Se a exibição dos seios e nádegas era algo corriqueiro entre elas ${ }^{17}$, a exibição do pênis se devia principalmente à exigência da parte deles, que queriam conferir o tamanho da "neca" - algo, como vimos, bastante valorizado no universo homoerótico. A incompatibilidade entre as exigências dos clientes e as da comunidade levava muitas vezes os moradores ou comerciantes a demandar a ação policial ou a lançar mão de estratégias próprias de combate à prostituição, como a de anotar as placas dos carros como forma de coagir os possíveis clientes das travestis a não frequentar mais o local ${ }^{18}$. Por implicar muitas vezes conflitos onde a violência era um elemento presente, tal tema será discutido no capítulo seguinte.

\section{(3) - o encarecimento do crédito e do aluguel.}

O problema da moradia era um dos considerados mais difíceis de serem equacionados pelas travestis estudadas. Uma das dificuldades referia-se ao requisito de se comprovar renda exigido por alguns locatários. O estigma que elas carregam fazia também com que estes logo imaginassem que elas levariam clientes para o

\footnotetext{
${ }^{17} \mathrm{O}$ padrão de decoro que as travestis exibiam quando reunidas difere muito daquele seguido pelas maior parte dos brasileiros. Era muito comum que uma mostrasse a outra seios ou nádegas, por exemplo, o que chegou, inclusive, a causar problemas na instituição em que o Grupo se reunia, já que às vezes estas o faziam em ambientes compartilhados com os pacientes da instituição, gerando reclamações por parte destes.

18 Tal estratégia é citada por Trevisan (2000, p. 420-1) e por reportagem do "Estadão" "Foto do carro do cliente: arma contra travestis - OESP: 03/12/2004). Na região da Cidade Universitária, moradores lançaram mãos de artifícios para dificultar a passagem de veículos em algumas ruas costumeiramente ocupadas por travestis e prostitutas, como a mudança da mão das vias e a colocação de barreiras para impedir a circulação dos carros [observação pessoal].
} 
imóvel, suscitando reclamações de vizinhos. Para "compensar" este risco, muitos locatários cobravam aluguéis mais altos e exigiam um depósito antecipado de vários meses. ${ }^{19}$.

Como resposta a estas exigências, elas se utilizavam de algumas estratégias. A principal era a de se reunirem em grupos e alugar coletivamente alguma casa ou apartamento. Esta era a alternativa mais barata de moradia, mas exigia alguns requisitos: um bom relacionamento entre as moradoras, algo sujeito a mudanças súbitas, como abordaremos a seguir, um bom relacionamento com os vizinhos, o que dependia do grau de transfobia no local, e uma preocupação pelo cuidado da casa ${ }^{20}$, algo que algumas travestis não possuíam, uma vez que a identidade feminina da "donade-casa" era algo recusado por elas, como vimos anteriormente.

Outra estratégia de moradia muito comum era a de se viver na pensão de alguma "cafetina". Esta possibilidade, escolhida como vimos anteriormente em função do conforto que representava e por oferecer alguma proteção, era mais comum entre as mais jovens, que podiam arcar com tais despesas em virtude dos maiores ganhos com a prostituição. O gasto para se morar em uma pensão de "cafetina" era bem mais alto do que o das demais modalidades. Em dezembro de 2002, morar em uma das duas pensões de uma das regiões de prostituição da Zona Norte de São Paulo significava um custo diário de $\mathrm{R} \$ 30,00$. Em virtude disso, assumia também uma conotação de status entre elas.

Morar com uma cafetina, porém, significava também estar submetida ao controle por parte desta, considerada uma figura perigosa por elas ${ }^{21}$. Embora a relação com ela

\footnotetext{
19 Welzer-Lang (1994) cita as dificuldades de se conseguir empréstimos e de se alugar imóveis pelo mesmo motivo como um problema comum nas diferentes modalidades de prostituição de Lyon (p. 140). Os aluguéis caros como consequência da discriminação são também citados por Kulick (1998) em relação às travestis soteropolitanas (p. 24)

20 A principal necessidade referia-se ao preparo dos alimentos. Muitas travestis, por não assumirem esta função, acabavam por se alimentar em restaurantes e bares, gerando um dispêndio financeiro elevado para seus ganhos financeiros.

${ }^{21}$ Em vários momentos no Grupo fui advertido a não questionar os altos preços pagos pelas travestis que moravam em pensões e não sugerir possibilidades alternativas de moradia, sob o risco de receber algum "doce", que na linguagem utilizada por elas tem a conotação de castigo, de ordem física, como uma surra, ou de ordem financeira, como um roubo.
} 
fosse muitas vezes, como vimos anteriormente, uma relação substitutiva da relação familiar, implicava em possível violência quando as diárias da pensão começavam a se acumular, sem pagamento. Neste caso, era comum que esta pressionasse as moradoras para que extorquissem ou roubassem seus clientes ${ }^{22}$. Algumas travestis, contudo, fugiam da referida pensão e eram comuns histórias de cafetinas que passavam anos perseguindo uma ex-hóspede, em episódios que por vezes terminavam em confrontos violentos. Um dos castigos comuns nestas disputas, descrito por elas, neste e em outros contextos, era o de se ferir o rosto profundamente, formando uma cicatriz permanente, algo muito temido por elas, zelosas por sua aparência.

A questão da moradia relacionava-se também com outra questão premente entre as travestis pesquisadas: o manejo dos ganhos financeiros. Havia entre elas uma frequente desvalorização do dinheiro vindo da prostituição, referido como um "dinheiro sujo". Muitas diziam ser ele "amaldiçoado" e que "entrava rápido e saía rápido", demonstrando uma desvalorização da própria atividade profissional. Da mesma forma que na expressão "sangue sujo", como referência ao fato de alguém ser portador do HIV, analisada anteriormente, a expressão "dinheiro sujo" parece remeter a uma "sujeira" moral, neste caso de quem ganha o dinheiro ${ }^{23}$.

Se seu ganho financeiro já era pouco, a desvalorização do mesmo fazia com que o dinheiro se tornasse ainda mais exíguo. Isso as impedia de poupar recursos em momentos de "vacas gordas", ${ }^{24}$ levando-as a gastos aparentemente exagerados com roupas e adereços, mas, principalmente, com drogas, forte escoadouro destes recursos. Gaspar (1985) observou o mesmo fenômeno entre prostitutas cariocas: o estilo de vida destas era às vezes incompatível com os rendimentos, acarretando endividamento e deixando-as na penúria.

\footnotetext{
${ }_{22}^{2}$ Os riscos envolvidos em uma dívida para com uma cafetina são também descritos por Benedetti (2000, $\mathrm{p}, .28)$.

23 Interessante observar que expressão equivalente- "argent sale” - é utilizada na prostituição francesa analisada por Welzer-Lang (1994, p. 101). Vale (2000) cita a expressão “dinheiro sujo” sendo utilizada também pelas travestis de Fortaleza (p 125)

24. Como a grande maioria das travestis de baixa renda viviam no limite da sobrevivência, sem conseguir economizar para os períodos mais críticos, meses de "baixo movimento”, como janeiro e julho, geravam um aumento da penúria e um consequente incremento dos furtos e roubos.
} 


\section{(4) - a falta de perspectiva profissional e o recurso a atividades ilegais}

Se a falta de perspectivas profissionais é comum em outras modalidades de trabalhadores informais, como a dos camelôs, tal fenômeno se intensifica na prostituição. No caso desta atividade, não só a progressão da idade é um elemento que faz com que os(as) profissionais(as) do sexo sejam considerados(as) menos atraentes ${ }^{25}$ como também o próprio estigma ligado à atividade faz com que se torne difícil a mudança de ocupação.

No caso das travestis, há, ainda, uma diferença delas em relação às demais modalidades de profissionais do sexo que merece ser ressaltada: a dificuldade muito maior de mudança de ocupação, em virtude das transformações corpóreas pelas quais passaram. Se a mulher prostituta pode, em muitos casos, esconder sua ocupação, anterior ou atual ${ }^{26}$, a travesti não, por carregar um estigma relacionado às transformações corpóreas facilmente identificáveis ${ }^{27}$.

Frente a isso, algumas travestis estudadas reconheciam o imperativo de se "fazer a vida" 28 enquanto jovem. O recurso de ir à Europa, acessível às "deusas", era descrito como tendo esta motivação principal. Para Silva (1993), a Europa é valorizada pelas travestis não somente como lugar de dinheiro e requinte, mas também porque simboliza um cruzamento de fronteiras análogo à mudança de gênero efetuada por elas (p 47). Algumas travestis do Grupo, mais jovens, sonhavam em ir para tal continente, mas reconheciam a necessidade de alcançar um padrão estético compatível para isso:

\footnotetext{
${ }_{25}$ Embora a progressão etária fosse um fator considerado negativo entre as travestis do Grupo, pelo desejo dos clientes por travestis mais jovens, esta modalidade de prostituição parece ser mais longeva do que outras. Uma das participantes do Grupo, que foi michê na juventude e "virou” travesti após os 25 anos, quando inquirida sobre os motivos da mudança, apontou a maior possibilidade de ganho da travesti na prostituição como a causa principal da transformação. Segundo Perlongher (1987a), a carreira do michê na prostituição é mais curta, indo até a cerca de 25 anos.

26 Segundo Moraes (1996, p. 36) “diferentemente de outras categorias estigmatizadas que tem características distintivas imediatamente evidentes, que não podem se clandestinizar - como é o caso dos negros e portadores de deficiência, o estigma da prostituta não é imediatamente percebido”

${ }^{27}$ Esta dificuldade é apontada também por Silva (1993)

${ }_{28}$ A expressão "fazer a vida" é com frequência usada por travestis para indicar uma certa estabilidade financeira. É interessante notar uma aproximação do termo com as expressões "cair na vida”, como referência à entrada na prostituição, tanto masculina como feminina, e "fazer o corpo", utilizada para se referir às mudanças corpóreas.
} 
P. [travesti que foi roubada por uma “cafetina” em R \$30.00o, episódio já citado anteriormente] disse que estava economizando para fazer várias cirurgias plásticas e para pagar a passagem. Contou que ia ter que começar tudo de novo, mas que desta vez não ia “dar moleza para as mariconas" [referência a que intencionava roubá-los ou extorqui-los mais do que já fazia anteriormente]

A visão de que a Europa Ihes garantiria tranquilidade financeira vitalícia, porém, era negada pela própria experiência de vida de algumas delas que já haviam lá vivido. Uma delas até conseguiu realizar parcialmente este projeto, voltando ao Brasil e abrindo um pequeno salão de cabeleireiro, apesar da dependência em heroína adquirida na Itália. Outra, porém, foi extraditada ao Brasil por imigração ilegal e envolvimento com a mesma substância. Uma terceira, operada, nunca contou os motivos de seu insucesso neste projeto de vida comum a elas ${ }^{29}$. Estas três travestis apresentaram muitas vezes uma visão francamente favorável dos clientes europeus em comparação com os brasileiros, considerando que os mesmos eram mais corteses, mais frequentemente "ativos" no relacionamento sexual e mais generosos com o pagamento.

No caso das travestis mais velhas, que não "fizeram a vida", eram poucas as ocupações referidas como acessíveis a elas, além da de profissional do sexo ${ }^{30}$ : Entre estas estavam ocupações que exigiam escolaridade, como, por exemplo, a de auxiliar de enfermagem, o que demandava dedicação financeira e temporal de longo prazo, uma vez que muitas tinham passado por um processo de escolarização precário.

Citavam também como alternativas atividades comumente associadas ao universo homoerótico, como a de transformista, cabeleireiro e manicure. Estas

\footnotetext{
${ }_{29}$ Trevisan (2000) cita estimativas que falam em 500 travestis brasileiras na França e outra 500 na Itália, em meados da década de 90. Observa que as mesmas na França foram acusadas de "roubar" clientes das prostitutas francesas e de gerar aumento da criminalidade. Na Itália muitas se tornaram dependentes e passaram a traficar heroína. (p 421-3)

30 Este tema era bastante discutido no Grupo, sem a perspectiva, porém, de incentivá-las a deixar a prostituição. A este respeito, considero que, embora haja a necessidade de se lutar pelo reconhecimento profissional e pela melhora das condições de trabalho no universo da prostituição, é importante que uma reflexão seja feita em relação ao quanto a prostituição é viável como ocupação a partir de uma certa idade. A exemplo de outras ocupações em que a idade progressiva é um elemento que limita o sucesso profissional - como é o caso de modelos e de jogadores de futebol - torna-se importante pensar, a partir de um certo momento, em alternativas onde a idade não seja um impedimento tão forte.
} 
atividades, porém, estão passando há algum tempo por um processo de retração como no caso do transformismo em clubes noturnos - ou de acentuada pauperização (como no caso de cabeleireiros e manicures) ${ }^{31}$.

Outras ocupações referidas eram próprias ao universo das travestis. Entre estas, a de "bombadeira", perigosa porque objeto de intensa perseguição por parte da polícia, como vimos anteriormente, ou de "cafetina", que demandava, porém, um investimento financeiro inicial alto:

J. contou no Grupo que já foi cafetina, que teve uma casa com oito travestis, mas que "não deu certo" porque ela estava em um período "muito viciada”. Disse, porém, que ela ainda ia abrir uma nova casa. [J. era uma das travestis que frequentemente roubava seus clientes 'imaginei que um de seus objetivos era acumular recursos para montar sua casa novamente]

Outra possibilidade era a da comercialização de produtos para as próprias travestis, como roupas, sapatos e cosméticos, o que era utilizado como recurso financeiro adicional por algumas travestis pesquisadas ${ }^{32}$. Uma delas, especificamente, se especializou em na confecção de calcinhas de vinil, especialmente desenhadas para esconder a "neca". Não era incomum que no encontros elas comercializassem peças de roupa e perfumes.

O emprego doméstico, em residências privadas ou nas próprias pensões para travestis, era também citado como uma alternativa ${ }^{33}$. Tal ocupação nas pensões, contudo, era bastante desvalorizada, uma vez que implicava em ficar na posição de serviçal frente às demais:

\footnotetext{
${ }^{31}$ Apenas para ilustração: segundo elas próprias, na região central de São Paulo, um corte de cabelo em salões populares custa por volta de $\mathrm{R} \$ 5,00$ (dados de 2003). O cabeleireiro que trabalha para o dono do salão fica com um porcentagem desse valor, geralmente entre 30 e $40 \%$

${ }^{32}$ Também citado por Benedetti (2000) que relaciona esta função como uma resposta à discriminação nas lojas, que não comercializam tamanhos apropriados e não permitem pagamentos a prazo para travestis (p. 64)

33 Algumas travestis trabalharam em empregos domésticos ("casa de família") antes da entrada na prostituição ou em momentos onde este mercado não estava lhes providenciando rendimento suficiente. Uma delas, especificamente, alternava a ocupação na prostituição e no emprego doméstico. Contava que era difícil a relação com os patrões neste último, por causa do intenso assédio sexual dos mesmos, o que gerava ciúmes nas esposas.
} 
Percebi que algumas travestis estavam "dando um close" ${ }^{34}$ para V. No decorrer do encontro, fiquei sabendo que ela aceitou trabalhar como empregada doméstica na pensão de P. [uma "cafetina"], para quem já estava devendo algum tempo de aluguel. V, nitidamente incomodada com o fato de ter que aguentar uma posição subserviente em relação às colegas, disse, tentando sair desse incômodo: "Pelo menos não tenho que ficar penando na rua como muitas aí, grudando cliente para conseguir pagar o aluguel'. Pensei que, se não fosse por seus aproximados um metro e noventa e cinco de altura, sem salto, V. seria facilmente feita de "bode expiatório" pelas colegas.

Ainda outra ocupação acessível a elas, embora restrita, era a de se tornarem agentes comunitárias de saúde. No caso do município de São Paulo, tal alternativa foi possibilitada por um programa específico direcionado à prevenção das DSTs e AIDS entre prostitutas, travestis e michês, ligado à Secretaria Municipal de Saúde, que envolvia a participação de profissionais do sexo como agentes comunitários e que recebiam auxílio financeiro pela função exercida ${ }^{35}$. Uma das travestis mais frequentes aos encontros, que exercia uma certa liderança sobre as demais, assumiu esta função em meados de $2002^{36}$.

Como as ocupações alternativas eram também pouco rentosas ou bastante restritas, muitas travestis acabavam por se manter na prostituição, apesar da situação de pauperização crescente bastante evidente. Entre os fatores intrínsecos à prostituição que determinavam um menor rendimento nesta atividade entre elas estavam a idade um pouco mais avançada - principalmente quando acima dos 40 anos - e o fato de

\footnotetext{
${ }^{34} \mathrm{O}$ termo se refere às travestis que tentam se mostrar "superior" às demais. Penso que tem origem na música feita por Erasmo Carlos para a conhecida travesti Roberta Close, cujo refrão diz "dá um close nela".

${ }^{35}$ Se os Programas de Prevenção em DST e AIDS específicos para travestis são iniciativas louváveis, mais ainda o são aqueles que incluem as próprias como agentes comunitárias ou multiplicadoras. Algumas travestis pesquisadas, porém, especialmente as que viviam em maior situação de penúria e/ou as que tinham dependência por alguma substância ilícita se utilizavam da comercialização dos preservativos distribuídos como fonte de renda. A estratégia era frequentar diversos serviços que os fornecessem e vendê-los em hotéis da região central. Por não ter como coibir tal prática, eu evitava distribuir muitos preservativos por encontro. Algumas travestis, em particular, me contavam quais eram as que realizavam mais comumente tal prática.

${ }^{36}$ Algumas ocupações alternativas à prostituição citadas no Grupo são semelhantes às descritas por Kulick (1998). Em Salvador travestis mais velhas recorriam ao tráfico de drogas, ao trabalho doméstico para outras travestis, e à posse de uma "barraca" para vender bebidas ou lanches, além das funções de "cafetina" e "bombadeira".(p. 39)
} 
terem AIDS, quando tal fato se tornava perceptível, o que levava os clientes em potencial a se afastarem. Isso, somado à falta de suporte financeiro, em decorrência do isolamento familiar e ao frequente uso abusivo de drogas, especialmente o crack, as levava a uma inquietude em relação ao futuro, o que era algo às vezes expresso nos encontros:

\begin{abstract}
Hoje foi contada a história de uma travesti da região da [...], que trabalhou durante anos nas ruas e que foi "decaindo" pouco a pouco, segundo elas. Começou a morar debaixo de um viaduto, porque não conseguia pagar mais aluguel e agora estava catando papelão para vender, "puxando carro". V. contou que ela tinha virado uma "mendiga". Notei uma apreensão no Grupo frente a uma realidade que poderia corresponder ao futuro delas mesmas.
\end{abstract}

Para fugir desta situação de miséria econômica ${ }^{37}$, muitas delas acabavam por recorrer a estratégias ilícitas como complemento da atividade de prostituição, às vezes substituindo-as completamente por elas. Entre estas, as principais referiam-se a roubos, furtos e tráfico de drogas. Embora tais atividades possam também ser descritas como “ocupações”, fazem jus a descrição em capítulo específico, por seu caráter ilegal e pela violência a elas associadas.

\title{
(5) - competição predatória e dificuldade de associação.
}

A escassez de clientes era um objeto de reclamação constante nos encontros. Muitas comparavam o "movimento" de clientes com o de décadas passadas, avaliandoo como muito menor. As razões mais atribuídas por elas a esta diminuição eram o advento da AIDS e o medo dos clientes, nos anos 80, e o crescimento de roubos e furtos aos mesmos, na década de 90, além da impressão de uma constante expansão

\footnotetext{
37 Em conversa com o secretário municipal de Assistência Social, Floriano Pesaro, este revelou ter recebido reivindicações específicas de travestis de baixa renda da região central de São Paulo, no sentido da disponibilização de um albergue específico para este segmento da população, pelo fato delas se sentirem muitas vezes discriminadas nos albergues existentes. (comunicação pessoal em dezembro de 2006) Tal fato mostra que a pauperização das travestis parece ter se acentuado ainda mais nos últimos anos
} 
do número de travestis nas ruas de São Paulo ${ }^{38}$. Mesmo que relativizemos tal comparação, uma vez que era feita pelas travestis mais velhas, e, portanto, menos valorizadas no mercado sexual, é bastante provável que as duas primeiras razões citadas tenham impactado negativamente a procura de clientes por travestis ${ }^{39}$.

A resposta mais comum à escassez de clientes era uma oferta de serviços sexuais a preços mais baixos, o que acabava gerando uma forte concorrência entre elas. A tensão gerada por este motivo era mais do que evidente. Um dos termos utilizados de forma pejorativa nos encontros mostra isso: "varejeira", vindo da expressão "fazer varejo", que se referia a cobrar menos pelos programas (tal termo parece fazer referência às lojas varejistas que fazem promoções, dão descontos, etc). Embora tivesse uma conotação negativa, algumas travestis se assumiam "varejeiras", criticando as colegas que diziam cobrar mais pelos "programas" do que de fato cobravam:

Em meio a uma discussão sobre os preços cobrados pelos programas, quando muitas diziam cobrar 20 ou 30 reais, L. se virou ao Grupo e disse: "Eu faço varejo mesmo, cobro três a chupeta e cinco a trepada”. Percebi que um certo silêncio se fez, como se ela tivesse evidenciado uma realidade que elas não queriam admitir, talvez para mim, talvez para si mesmas.

Era comum também relatos da decepção de ficar muito tempo nas ruas e não conseguir nenhum cliente. Outro termo, também pejorativo, utilizado entre elas para designar a travesti que não conseguia clientes era o adjetivo "penosa", que se referia ao fato de se passar muito tempo "penando" nas ruas, algo que era sentido de uma forma bastante sofrida:

\footnotetext{
${ }^{38}$ Ferreira (2003) cita as mesmas queixas entre as travestis de Belém, relacionando tal fato ao medo dos clientes da AIDS e da extorsão policial, além das brigas e furtos praticados pelas travestis (p. 69)

${ }^{39}$ Quanto à terceira razão, o maior número de travestis nas ruas, é difícil avaliar sua precisão. Considero que é lícito supor, neste sentido, que um número maior de travestis esteja envelhecendo na prostituição em função do surgimento dos medicamentos antiretrovirais, voltados ao tratamento da AIDS a partir dos anos 90. O uso destes medicamentos, disponibilizados pela rede pública de saúde, certamente permitiu uma diminuição significativa da mortalidade precoce neste segmento da população.
} 
B. contou que sempre tentava sair com o primeiro cliente que aparecia, não importando quanto pudesse pagar. Disse que para ela era importante "abrir o caixa”, porque ficava "neurótica”, caso ficasse algumas horas na rua sem arrumar ninguém.

Se algumas passavam a maior parte do tempo culpando aquelas que roubavam ou furtavam clientes pelo pouco movimento, por vezes surgia entre elas um ideal de uma "associação", de criar uma organização como forma de combinar preços e lidar com outras dificuldades ligadas ao seu universo. Busquei sempre incentivar tal movimento, mas as próprias travestis diziam insistentemente que isso era "muito difícil", que elas eram "assim mesmo", que "não se uniam nunca"40.

A atribuição de uma competição intrínseca ao fato de se ser travesti parecia negar o fato de que eram as próprias relações de trabalho que geravam esse problema entre elas. Apesar disso, houve um momento, motivado pelo assassinato de uma travesti da região da Av. Cruzeiro do Sul, que, segundo elas, teria sido sepultada como indigente, que suscitou uma discussão mais aprofundada sobre o tema. Tal movimento foi ajudado pela frequência de duas novas travestis aos encontros, que trouxeram seu desejo de contar com uma "associação de verdade", inclusive legalizada. Nesse momento, me dispus a buscar informações sobre os procedimentos legais necessários para se formar uma ONG, pensando em auxiliá-las nesse sentido. Encontrei um grande obstáculo de ordem jurídica: as ONGs, para serem regularizadas, precisam de um diretoria que possa atestar ter "bons antecedentes criminais", algo raro entre elas. Este momento - no primeiro semestre se 2002 - foi aquele em que as discussões sobre a necessidade de união foram mais intensas. Logo depois, porém, se dispersou, devido ao fato de várias travestis mudarem de cidade, por conta do baixo movimento do mês de julho, algo comum, segundo elas mesmas, por causa do frio e das férias escolares.

\footnotetext{
${ }^{40}$ Kulick (1998) caracterizou a relação entre as travestis como marcada pela suspeita e desconfiança (p. 41 ), relacionando tal fato com as dificuldades financeiras, o que fazia com que as mesmas aproveitassem a oportunidade para tingir seus objetivos, mesmo que isto implicasse numa traição às companheiras (p. 43). Ferreira (2003) relacionou o mesmo fenômeno, em Belém, à competição relacionada ao trabalho e à antipatia pessoal entre as travestis (p. 89). Esta competitividade dentro dos grupos é também ressaltada em estudos sobre outras modalidades de prostituição, como pode ser deduzido da observação de Perlongher (1987a) de que "não há amizade entre michês" (p. 167), em seu estudo sobre michês paulistanos.
} 


\section{Os Clientes}

A demanda por determinadas formas de relacionamento sexual por parte dos clientes determina em certa medida as configurações da prostituição. Nas palavras de Welzer-Lang (1994), "la prostitution s'adapte à la société où elle prend corps” (p.15). É em virtude, portanto, do desejo dos clientes que a prostituição travesti se organiza, fazendo destes personagens importantes em qualquer discussão que se refira ao tema.

A consideração dos clientes, contudo, é aqui feita com base nas descrições que as próprias travestis estudadas faziam dos mesmos, uma vez que não tivemos contato direto com eles, ao contrário do ocorrido com alguns "maridos". Como vimos anteriormente, tal contato é difícil e o único estudo disponível sobre o tema, o de Pelúcio (2005a) retrata um segmento reduzido dos mesmos, que se auto-intitulam "Tlovers". Estes trocam informações sobre travestis pela Internet e tem uma reunião semanal aberta em um bar da região central de São Paulo, assumindo-se como "adoradores" de travestis e relacionando-se principalmente com as "deusas" - travestis de alta renda ${ }^{41}$. Embora interessante, o estudo não parece retratar os clientes típicos das travestis, ao menos daquelas frequentavam o Grupo.

A descrição por elas dos clientes mostrava uma evidente heterogeneidade dos mesmos. Havia aqueles que as buscavam, segundo elas, como "mulheres", mantendo relacionamento sexual apenas "ativo", outros que procuravam por sexo "passivo"42 e ainda aqueles que praticavam as duas modalidades de relação. Havia ainda aqueles, minoritários, que demandavam por agressões físicas, solicitando-as a agir neste

\footnotetext{
${ }^{41}$ Em uma conversa com um integrante da comunidade virtual e participante das reuniões dos T-Lovers, o mesmo considerou que a motivação principal de tal frequência seria a busca de um apoio mútuo frente ao preconceito voltado a quem se relaciona sexualmente com travestis - em suas palavras, "amar uma travesti é uma experiência muito marginal". Além disso eram locais de troca de informações a respeito de quais travestis seriam potencialmente violentas (comunicação pessoal de N. em agosto de 2005). O site da comunidade na Internet elabora inclusive uma "lista negra" das mesmas. A busca dos T-Lovers em não serem associados à homossexualidade é descrita por Pelúcio (2005a), que considera que os mesmos reproduzem a masculinidade hegemônica, exagerando os atributos considerados masculinos. Vale (2000) em seu estudo sobre a prostituição travesti em um cinema de Fortaleza, cita a mesma preocupação entre os clientes das travestis dali (p. 109).

${ }^{42}$ Kulick (1998) chama a atenção para o fato das travestis talvez exagerarem a quantidade de clientes que busquem por sexo "passivo" com elas (p. 160).
} 
sentido, e a procura por parte de casais, que buscavam relacionamento sexual da travesti com o homem, a mulher ou ambos.

A idade dos clientes era referida também como bastante variada, embora os mais velhos predominassem. A combinação da idade mais avançada com o desejo por relacionamento sexual passivo correspondia ao cliente que denominavam "maricona", o tipo mais depreciado por elas, o que se dava tanto por sua passividade como pela idade. Como mostra Perlongher (1987a), em seu estudo sobre michês de São Paulo, a idade leva a uma desvalorização no universo homoerótico, dificultando o encontro de parceiros para relações sexuais ocasionais e gerando a necessidade de se pagar pelas mesmas (p. 124). Este e o fato de haver uma certa correlação entre idade e disponibilidade financeira explicaria o fato de michês terem como clientes mais comuns homossexuais mais velhos, para este autor. Consideramos que tal interpretação é também apropriada para o caso dos clientes das travestis aqui investigadas. Mas estas eram procuradas também, embora minoritariamente, por clientes mais jovens, denominados de "boy", bem mais agradáveis a elas, mesmo quando buscavam por relações sexuais "passivas" - casos em que eram referidos como bicha-boys.

Um outro ponto que mostra a prostituição como determinante do universo das travestis estudadas era o desempenho do sexo anal ativo com seus clientes. Embora a grande maioria preferisse relações sexuais passivas ${ }^{43}$, o desejo dos clientes em serem penetrados acabava prevalecendo, o que fazia com que estes fossem muitas vezes objeto de escárnio dentro do Grupo, algo que denotava uma certa raiva pela situação vivida.

A submissão das travestis aos desejos e necessidades dos clientes podia ser observada também na forma com estas se relacionavam com o próprio corpo. A transformação do mesmo era em certa medida determinada pelas demandas dos clientes, como no caso analisado da evitação da cirurgia de transgenitalização. Ter seios e nádegas grandes era algo também descrito não somente como fruto da

\footnotetext{
${ }^{43}$ Isso é algo que não pode ser generalizado para todas. Algumas referiam gostar de se relacionar de forma ativa, inclusive tendo relações sexuais com mulheres.
} 
necessidade de satisfação pessoal por parte delas, mas, também, como algo comumente desejado pelos clientes ${ }^{44}$.

As travestis investigadas formulavam algumas hipóteses para a procura específica de clientes pelo sexo com elas. Alguns deles eram considerados "bichas enrustidas", que as procuravam, segundo elas, porque não conseguiam se "assumir" como homossexuais, "fingindo" para a sociedade - e talvez para si mesmos - que buscavam por um relacionamento com uma mulher, quando na verdade o estavam fazendo com um homem. Tais clientes eram os mais visados para extorsão financeira por parte delas e mantinham relações sexuais em uma atmosfera de culpa ${ }^{45}$. Esta interpretação, contudo, não era por elas generalizada para o conjunto dos clientes, uma vez que havia os que aparentemente buscavam por práticas sexuais que suas esposas não lhes proporcionavam, como sexo anal e oral ${ }^{46}$.

Alguns autores relacionam a procura por relacionamento amoroso e sexual em relação à transgêneros como a busca por um ideal de feminilidade estereotipada, associada á sedução, que, segundo Welzer-Lang (1994) as mulheres "de verdade" não mais encarnariam, por conta da recente emancipação feminina, que as faria recusar a posição de "mulher-objeto". Essa "mulher ideal" seria mais facilmente inventada por um homem, pelo fato dele conhecer mais profundamente os desejos masculinos, algo que é proposto, em relação às travestis no Brasil, por Vale (2000, p 58 e 119). Estes argumentos, semelhantes aos abordados no item que diz respeito à construção da "mulher super-sedutora" pelas travestis, são interessantes, mas tendem a generalizar seus clientes como portadores de um única forma de desejo e um único conjunto de fantasias, o que consideramos equivocado. Entre as travestis pesquisadas, a descrição de clientes variados, com fantasias diversas, sugere a imprecisão de tal estereotipia.

\footnotetext{
${ }^{44}$ A esse respeito, Pelúcio (2005b) cita que as travestis atuais tem estilo menos exagerado, buscando formas menos voluptuosas, seios menores e roupas mais adolescentes, aproximando-se de um estilo "patricinha". É importante considerar, contudo, que sua amostragem refere-se predominantemente a travestis de alta renda. Não observei tal fenômeno entre as de baixa renda, que tinham como modelo identificatório, como vimos, a figura da "mulher fatal".

${ }_{45} \mathrm{Um}$ outro elemento que indicava que as travestis tinham clientes muitas vezes culpados era a demanda insistente por sexo sem preservativo da parte deles em relação àquelas que reconhecivelmente já tinham desenvolvido a AIDS. Tal relação era feita por elas próprias.
}

${ }_{46}$ Também citado por Ferreira (2003, p 72) 


\section{O "malandro"}

Apesar de, em certa medida, estarem em uma posição de subserviência em relação a seus clientes, por dependerem financeiramente dos mesmos, não era assim que as travestis estudadas os enxergavam. O mais comum nos discursos em referência aos mesmos era desqualificá-los, como vimos no caso das "mariconas". Se com os "maridos" as travestis aceitavam quase sempre uma posição de submissão e na relação com os vícios a relação parecia mais igualitária, na relação com os clientes pareciam buscar, na maior parte das vezes, se sentir em uma posição de domínio sobre os mesmos. Consideramos, assim, que, nessa relação, uma outra figura identitária pode ser percebida como sendo parcialmente por elas incorporada: a do malandro.

Silva (1993) refere, no início de seu estudo sobre travestis no Rio de Janeiro, ter a hipótese inicial de que o personagem travesti poderia ser entendido como uma metamorfose do malandro carioca (p. 31), hipótese à qual não volta a se referir em seu trabalho. Penso ser interessante a retomada dessa hipótese de uma outra forma: não a de que a travesti corresponda a uma transformação do malandro, mas a de que a identidade do malandro seja parcialmente incorporada na identidade travesti.

A figura do malandro tem sido analisada por diversos cientistas sociais no Brasil. Cândido (1993), em sua análise de "Memórias de um Sargento de Milícias", considera o personagem central do romance, Leonardo, como o primeiro malandro da novelística brasileira. O malandro tem, para ele, proximidade com "tricksters" de outras literaturas, inclusive de fábulas infantis, representada pelas figuras do macaco e do jabuti, e do folclore, como o personagem Pedro Malasartes. É uma figura que transita entre o universo da ordem e da desordem, não se fixando em nenhum dos dois e permanecendo em um lugar ambíguo. Em continuidade com a análise de Antônio Cândido, Da Matta (1983), em seu clássico “Carnavais, Malandros e Heróis”, faz considerações importantes a respeito de como a figura do malandro se descola da figura do bandido ou marginal. Avalia, ao analisar o mito de "Pedro Malasartes", que o malandro não vive nem no mundo da ordem (do trabalho formal) nem no da desordem 
(da criminalidade), "vive nos seus interstícios, entre a ordem e a desordem, utilizando ambos e nutrindo-se tanto dos que estão fora quanto dos que estão dentro do mundo quadrado da estrutura" (pg 139).

Considerando especificamente a figura do malandro carioca, Zaluar (2004) observa também diferenças com a figura do bandido. O malandro, personagem da boemia carioca até meados da década de 60 , participava intensamente da vida cultural da cidade e do espaço público, embora fosse continuamente associado ao golpismo e à preguiça (p 61). O bandido, em especial aquele surgido no rastro do tráfico de drogas no Rio de Janeiro, a partir da década de 70, por outro lado, não participa deste mesmo espaço público, uma vez que não leva em consideração o "outro", em sua busca pela maximização dos lucros nos grandes mercados da contravenção e do tráfico de drogas. A autora observa, contrapondo o funk ao samba de morro carioca, que no último impera a "capacidade de se colocar como um igual, com todos problemas e deficiências de qualquer um" (p. 391), algo associado a algumas representações do malandro.

Questionando tais análises, Misse (1999), em sua abordagem da transformação histórica do imaginário associado ao banditismo no Rio de Janeiro, considera que opor o malandro ao bandido corresponde a uma idealização do primeiro e à estigmatização do segundo (p 7). Tal visão "romântica" do malandro, criada nos anos 60, para ele, o representa como alguém avesso à violência, (p. 187) e o associa

\footnotetext{
“à recusa ao trabalho e a sua substituição por atividades ilícitas, expedientes de 'ganho' como o jogo, o furto e o estelionato ou à sua preeminência em mercados ilícitos, que exigem certos talentos e habilidades, principalmente a prostituição e o jogo, ou em situações delicadas, como nas estratégias de sedução” (p 253)
}

As diferenças entre as representações comumente associadas ao malandro e ao bandido ou marginal são resumidas por este autor em um quadro, aqui reproduzido (p. 185) :

\begin{tabular}{|l|l|}
\hline Malandro & Marginal \\
\hline $\begin{array}{l}\text { Inteligente, astucioso, simpático, "não } \\
\text { perde o controle" }\end{array}$ & $\begin{array}{l}\text { Ignorante, agressivo, antipático, } \\
\text { descontrolado }\end{array}$ \\
\hline Prezado por sua comunidade & Desprezado pela sua comunidade \\
\hline
\end{tabular}




\begin{tabular}{|l|l|}
\hline Individualista & Quadrilheiro \\
\hline Evita o enfrentamento direto & $\begin{array}{l}\text { Busca o enfrentamento direto, com } \\
\text { armas de fogo }\end{array}$ \\
\hline $\begin{array}{l}\text { Crimes: estelionato, sedução, } \\
\text { lenocínio, furto qualificado, } \\
\text { contrabando e contravenção (jogo de } \\
\text { azar, jogo do bicho, porte de arma) }\end{array}$ & $\begin{array}{l}\text { Crimes: Roubo, assalto a mão armada, } \\
\text { estupro, latrocínio, tráfico de drogas. }\end{array}$ \\
\hline
\end{tabular}

Misse (1999) observa que tal representação não pode ser tomada de forma definitiva, como se existissem tipos sociais estanques atravessando todo o século $X X$. Observa que o malandro, nas representações e ele associadas na primeira metade do século XX, era considerado bastante perigoso, diferentemente do que passou a ocorrer nas representações posteriores ( $p$ 390). Propõe que tal figura, assim como outras associadas ao banditismo, como as do marginal, do valente e do vagabundo, seja compreendida a partir de sua historicidade e observa que tais figuras tem conotações diferentes no "mundo do crime" e nos discursos que circulam por outros setores sociais, se modificando e, por vezes, se fundindo umas às outras em seu processo de transformação ${ }^{47}$.

Embora os argumentos de Misse (1999) sejam bastante convincentes, é importante considerar, em nosso estudo, que é justamente a figura imaginária do "malandro" que está em jogo, quando falamos de sua incorporação parcial pelas travestis na formação de sua identidade. Não haveria, é claro, como pensar de outro modo, uma vez que o surgimento das travestis como segmento social (anos 70) é posterior à "morte" ou "aposentadoria" do "malandro" histórico, personagem que desaparece em meados dos anos 60 .

A figura do malandro é bastante presente no universo da prostituição. Historicamente, é muitas vezes associada à figura do "cafetão", como mostra Misse (1999). Feldman (1989) mostra que a vinculação entre estas duas figuras não era

\footnotetext{
${ }^{47}$ Ramalho (1983), em seu estudo no Complexo Penitenciário do Carandiru, refere que a representação do malandro ali era a de alguém que tinha o domínio das regras e códigos da cadeia, sendo capaz de lidar com os obstáculos ali dentro e de enganar a polícia.(p. 64-5). No "mundo do crime", portanto, não se coloca como uma figura oposta ao bandido, observação semelhante à feita por Misse (1999)
} 
absoluta, na prostituição da região da Santa Efigênia e Campos Elíseos, zona central de São Paulo, nas décadas de 50 e 60. Observa que estes bairros eram apropriados simultaneamente pos mulheres prostitutas e por indivíduos que se enquadravam em atividades ilícitas, como os malandros ${ }^{48}$ (p. 123), que passaram a sobreviver da exploração da prostituição. Uma das principais fontes de renda de tais malandros, para este autor, era a sub-locação de imóveis para moradia entre as prostitutas da região. Não se configuravam, portanto, como cafetões no sentido usual, uma vez que não recebiam diretamente das prostitutas pelos "programas" que faziam, embora as explorassem economicamente cobrando aluguéis altos.

A diferenciação entre as figuras do cafetão e do malandro é mais explicitada no estudo de Moraes (1996) a respeito da prostituição na Vila Mimosa, no Rio de Janeiro. Nela, a figura do cafetão é claramente censurada, por conta da exploração a que submete as prostitutas e que aparece sob a forma de comportamentos abusivos, como “obrigá-las a cumprir programas indesejados, conduzi-las ao trabalho dopadas, viciálas, deixá-las sem dinheiro, expô-las a situações de risco com os clientes, agredi-las, etc" ( $p$ 151). Por isso, é uma figura quase em extinção na Vila Mimosa. O malandro, por outro lado, aparece como uma figura mitificada e valorizada por elas. Embora não exista mais o malandro histórico, as prostitutas costumam ter, segundo a autora, envolvimento afetivo com homens que carregam traços desta figura. Estes são aqueles que transitam pela "zona", bebendo e jogando e que buscam seduzir as prostitutas em busca de relacionamento amoroso e/ou sexual, mas sem fazer uso da violência. São tidos como companheiros e como pessoas carinhosas e mantém relações cordiais com os outros personagens da "zona", sendo ajudados financeiramente, às vezes, pelas prostitutas com quem se relacionam.

Moraes (1996) considera que o fascínio despertado pelo figura do malandro na Vila Mimosa se devia a um encantamento com a postura transgressora a que é associado. A questão que se coloca aqui é se esta postura não seria comum à própria prostituição, em muitas de suas modalidades. Em seu estudo sobre michês paulistanos, Perlongher (1987a) considera a michetagem como uma recusa à ordem formal -

\footnotetext{
${ }^{48}$ Essa contiguidade geográfica é também citada por Perlongher (1987a, p. 26 e 49))
} 
relacionada à disciplina do trabalho - e não somente como uma impossibilidade de acesso ao trabalho, devido ao desemprego (p. 294). Tal interpretação é muito próxima às considerações clássicas que são feitas em relação à malandragem. Pode-se pensar, assim, que o malandro não tem apenas proximidade geográfica com o universo da prostituição dos michês, mas que, mais do que isso, se torna uma figura incorporada por eles.

Da Matta (1983), como vimos, associa o bandido à ilegalidade e o malandro a alguém que vive entre os espaços da legalidade e da ilegalidade. Se refletirmos nestes termos sobre os espaços que os profissionais do sexo ocupam nas últimas décadas na sociedade brasileira, podemos associá-los aos mesmos ocupados pelo malandro na proposta deste autor. Na medida em que a prostituição não é considerada um crime, mas também não é uma atividade legalizada, isso a deixa exatamente nesta brecha entre os mundos da legalidade e da ilegalidade - ou, se utilizarmos os termos de Cândido (1993) - da ordem e da desordem.

Ser, em alguma medida, "malandro", no universo da prostituição, parece se fazer necessário, principalmente se considerarmos que a figura do cafetão - por vezes associada ao "malandro" - está em plena decadência na prostituição feminina e é praticamente inexistente na masculina. Sem nenhum tipo de proteção jurídica, por não terem sua profissão reconhecida legalmente, e sem ninguém para Ihes "proteger", cabe, muitas vezes, às próprias prostitutas, michês e travestis a busca de recursos para conseguirem se posicionar de forma não-submissa no universo da prostituição.

Em relação às travestis de baixa renda investigadas, consideramos que a incorporação da figura do "malandro" era algo claramente perceptível na relação que estabeleciam com seus clientes. A oposição entre o "malandro" e o "otário" 49 parece descrever de forma bastante próxima a relação estabelecida, muitas vezes, entre elas e seus clientes. A busca pelos diversos "truques" e estratégias para enganá-los era objeto

\footnotetext{
${ }_{49}$ A figura do “otário” é descrita por Misse (1999) como a figura complementar à do malandro.
} 
frequente de conversas nos encontros, usualmente com elas se vangloriando de suas ações e rindo dos clientes "otários" 50 .

Entre as estratégias utilizadas por elas para aumentar os ganhos no "programa" estava a de cobrar menos para atrair o cliente para um atividade sexual específica (por exemplo, sexo oral) e depois seduzi-lo para outra modalidade de relação (por exemplo, sexo anal). Como o acordo financeiro não era feito de antemão, isso lhes permitia cobrar um valor muito maior do que o usual.

Outro recurso utilizado para ludibriar os clientes referia-se a alguns "truques", como o de simulação da introdução do pênis no ânus, já citado. Se a ereção não ocorresse com o cliente desejoso de ser penetrado analmente e tal "truque" não fosse possível, a travesti comumente o acusava de ser pouco atrativo sexualmente e cobrava o valor estipulado anteriormente de forma integral. O recurso de urinar no ânus do cliente para simular uma ejaculação também era referido por algumas ${ }^{51}$.

A tentativa por parte dos clientes de inverter a relação de domínio que as travestis estabeleciam em relação a eles era sempre punida. Se o furto ou roubo aos clientes era condenado por algumas delas, todas concordavam com algum tipo de punição financeira ao cliente que as tentasse enganar. Ou seja, em hipótese alguma era permitido ao cliente fazê-las de "otárias". Um episódio recorrente a esse respeito, descrito nos encontros, era o do cliente que pedia um "desconto" pelo programa, referindo não ter dinheiro suficiente para pagar a quantia sugerida pela travesti, e que depois mostrava ter na carteira a quantia em questão. A punição neste caso era quase sempre a totalidade do dinheiro que houvesse na carteira ${ }^{52}$.

As estratégias utilizadas para manter os clientes na posição de dominados podem ser classificadas em duas modalidades, que frequentemente se somavam: o

\footnotetext{
50 Segundo Welzer-Lang (1994), da mesma forma que há uma reificação da(o) prostituta(o), na prostituição o cliente é também reificado, reduzido a um pênis e uma carteira (p. 67 e 107)

${ }^{51}$ Também citado por Perlongher (1987a) entre michês (p. 231). Tal “truque” era referido como difícil pelas travestis do Grupo, uma vez que exigia um grande controle da micção, que nem todas tinham.

52 Pelúcio (2005b) afirma, a meu ver equivocadamente, que os castigos e multas aos clientes só eram praticados pelas “tops”, travestis de alta renda, por atenderem "em condições mais confortáveis e seguras, além de trabalharem com homens mais endinheirados e temerosos de escândalo”
} 
"escândalo" e o uso da força física. O escândalo é uma estratégia comum na prostituição feminina, como mostram Gaspar (1986) e Freitas (1985) ${ }^{53}$. Para Gaspar (1986), o escândalo é uma alternativa de controle frente à possível violência do cliente. Relaciona este procedimento às teses de Goffman (1982), para quem os grupos estigmatizados frequentemente tentam tirar proveito das acusações de que são vítimas. Neste caso há a manipulação da própria identidade deteriorada: chamando atenção para si, expõe-se o cliente, muitas vezes envergonhado com a situação, constrangendo-o a pagar um "resgate" 54 .

Entre as travestis estudadas o "escândalo" era uma estratégia comum, devido ao receio frequente dos clientes em serem identificados como homossexuais e/ou clientes de travestis. As ameaças mais frequentes delas eram a de chamar a polícia ou de anotar o número da placa do carro - neste caso diziam ter um amigo no DETRAN que Ihes conseguiria seu endereço e ameaçavam mandar uma carta para sua casa, "contando tudo". As travestis identificavam os clientes com aspecto mais "assustado" e se utilizavam disso como uma estratégia para aumentar os ganhos com o programa, cobrando a mais pela demora no ato sexual ou pela repetição do mesmo e os "multando" por terem procurado outra travesti ${ }^{55}$ ou por alguma observação considerada indevida:

\footnotetext{
Um dos assuntos discutidos hoje foi o dos truques para se conseguir mais dinheiro dos clientes. P. contou que um cliente na noite anterior tinha comentado do tamanho de sua 'neca' e ela disse para ele que ele não podia fazer um comentário daqueles para uma 'menina' como ela e que por isso ele ia ter um castigo - pagar $\mathrm{R} \$ 20,00$ a mais. Todas riram da história e várias contaram episódios onde os clientes apareceram sempre no lugar de 'trouxas'.
}

\footnotetext{
${ }^{53}$ Freitas (1985) considera o "escândalo" uma estratégia inerente à prostituição de rua. Em bordéis, pela negociação antecipada dos valores e pela lógica mais "empresarial" do negócio, este fica impossibilitado.

${ }^{54}$ Uma visão alternativa é a de Arent (1999), que vê no escândalo uma possível resistência do profissional do sexo em colocado como objeto sexual (p. 150-1), uma vez que, para ela, a prostituição se configuraria como uma expropriação do próprio desejo, a fim de atender o do cliente.
}

${ }_{55}$ Tal "castigo" é também citado por Kulick (1998, p 155) 
Quando a estratégia do escândalo não era suficiente, algumas lançavam mão de ameaças físicas, às vezes brigando de fato com eles ${ }^{56}$. Não era nem um pouco incomum a presença de alguma delas aparecer com alguma marca no corpo ou no rosto, fruto de algum episódio nesse sentido. Embora saíssem por vezes machucadas desse enfrentamento, estes clientes eram referidos de forma mais positiva pelas travestis investigadas, por não terem tido se submetido a elas, o que corresponderia, portanto, a uma postura mais "máscula" da parte deles, algo por elas valorizado:

P. estava com a região de um dos olhos bastante inchada. Contou que tinha tentado tirara "um dinheiro a mais" de um cliente, ameaçando-o levar à delegacia e este a enfrentou: "Vamos agora”, se encaminhando até uma delegacia próxima. P. virou a direção do carro, quase fazendo ele se chocar com um poste. O cliente parou o carro e ambos se atracaram. Ela foi espancada, mas conta que também conseguiu feri-lo com as unhas. Disse para as outras integrantes que pensou que ia ser fácil, que "ele era magrinho", mas que acabou se “dando mal". D. contou um caso onde ela apanhou de um cliente que "também era um homem de verdade".

Um dos elementos que chamam a atenção em relação à identidade do malandro, é que esta se coloca entre as identidades pertencentes ao campo da masculinidade em nossa cultura. Se a identidade do "viado" é considerada como pouco masculina, a do malandro não ${ }^{57}$. A associação do malandro com a masculinidade não se dá em termos somente de sua violência potencial ou real, uma vez que, como vimos, o malandro não é representado como uma figura eminentemente violenta ${ }^{58}$. Tal associação parece se fazer mais em função do lugar de dominador que o malandro estabelece em relação a

\footnotetext{
${ }^{56}$ Em relação à prostituição feminina no Rio de Janeiro, Gaspar (1985) observa de forma semelhante que a violência direcionada ao cliente que não cumpria o acordo feito era algo considerado plenamente justificável para elas (p. 120)

${ }^{57}$ No caso das travestis, o cliente "passivo" parece ficar no lugar do "viado", portanto em uma posição mais feminina, o que confere um lugar masculino a quem o explora, como a travesti, como mostra Benedetti (2000, p 124).

${ }_{58}$ Podemos abstrair de um dos exemplos de Zaluar (2004) que a figura do malandro carioca incorporou também, ao menos parcialmente, a figura do "cabra macho" nordestino, observável na presença de migrantes nordestinos no Rio, como é o caso de Madame Satã, pernambucano, e Bezerra da Silva, paraibano (p 392-3). Neste caso, o malandro/cabra macho passa a responder com violência em defesa de sua honra. No caso das travestis do Grupo, em grande parte migrantes norte/nordestinas, tal associação também não pode ser desprezada.
} 
suas figuras complementares: a "mulher de malandro" e o "otário". Assim, se na relação com o "marido" as travestis do Grupo se colocavam em uma posição feminina submissa, que se aproximava da de "mulher de malandro", na prostituição, assumiam frequentemente a do próprio malandro, deixando o cliente nesse lugar submisso. Essa e outras contradições serão discutidas na parte final deste estudo. 


\section{VIOLÊNCIA}

A violência era onipresente no universo das travestis de baixa renda estudadas. Aparecia em diversos contextos, nos abusos sexuais e espancamentos na infância, na marginalização social a elas impingida, na relação com seus "maridos", na interação com os clientes, na perseguição policial, nos insultos e ofensas a elas cotidianamente dirigidos, nos procedimentos de transformação corporal rudimentares a que se submetiam, nos assassinatos de que eram vítimas frequentes, entre outros ${ }^{1}$. Por isso a violência é considerada aqui como um eixo fundamental do universo vivencial das travestis, ao lado dos três outros - gênero, corpo e trabalho - analisados anteriormente e com os quais se sobrepõe em muitos pontos.

A violência é algo de difícil definição. Para Misse (1999), "não existe 'violência', mas violência múltiplas, plurais, em diferentes graus de visibilidade, de abstração e de definição de suas alteridades"(p. 38). Considera que o termo é representado como uma "idealidade negativa" que se opõe a outra, "positiva", de paz, justiça, segurança e harmonia. Por isso, em seu estudo sobre o que denomina "acumulação social da violência" no Rio de Janeiro, abdica de trabalhar com um conceito de violência, preferindo analisar as representações da mesma (p. 41).

Zaluar (2004) observa a multiplicidade de sentidos que foram dados ao conceito na produção de diversos cientistas sociais, mostrando que entre estes a violência foi definida como um instrumento que abdica "do uso da linguagem que caracteriza as relações de poder, baseadas na persuasão, influência ou legitimidade", como "o não-

\footnotetext{
1 Todos os estudos sobre travestis descrevem a violência a elas direcionada. Dois deles, porém, relativizam tal fato. Marcelo Oliveira (1997) considera que em cidades menores, como Florianópolis, lugar em que faz sua pesquisa, a violência sofrida pelas travestis é menor. Pelúcio (2005b) considera que é necessário desmistificar a idéia de que o cotidiano das travestis seja violento, afirmando que esta é menor do que se acredita. Sua pesquisa, porém, volta-se predominantemente a travestis de alta renda, o que talvez possibilite tal afirmação.
} 
reconhecimento, a anulação ou a cisão do outro", como a "negação da dignidade humana", como a "falta de compaixão", como a "palavra emparedada ou o excesso de poder", observando que

\footnotetext{
"em todas elas ressalta-se, explicitamente ou não, o pouco espaço existente para que se manifeste o sujeito da argumentação, da negociação ou da demanda, enclausurado que fica na exibição da força física pelo seu oponente ou esmagado pela arbitrariedade dos poderosos que se negam ao diálogo” (p. 239)
}

Ao analisar especificamente a violência associada ao tráfico de drogas nas últimas décadas no Rio de Janeiro, a autora vê uma interrupção intensa dessa argumentação e da negociação, que se configura como uma recusa em participar do espaço público. A violência nos morros cariocas aparece, para ela, associada a um "etos guerreiro", que se manifesta pelo seu uso expressivo - com o intuito de afirmar a vitória de um grupo de homens sobre outro - e instrumental - com o objetivo de aumentar os ganhos comerciais.

Se aceitarmos a definição de violência feita por Zaluar como pertinente, ainda que imperfeita, cumpre refletir sobre o porquê das travestis serem vítimas de tantas modalidades de violência. É possível a consideração que isso se deve à recusa de sua entrada neste espaço público de negociação. Se não há o reconhecimento destas enquanto sujeitos, pelo próprio fato, como vimos, de escaparem às classificações sociais estabelecidas, como incluí-las como um segmento significativo neste espaço público? Caso aproximemos, aparadas algumas arestas, o conceito de "espaço público" do de "mundo da ordem" visto anteriormente, fica claro que só resta às travestis ocupar os interstícios, vivendo entre o mundo da ordem e da desordem, como ocorre na prostituição e na "malandragem", ou então mergulhar de vez no mundo da desordem, da criminalidade, que é o que de fato ocorria muitas vezes entre as travestis pesquisas.

As diversas formas de violência a que estas eram submetidas se condensavam em seu corpo, nas cicatrizes ${ }^{2}$ :

\footnotetext{
2 A observação das inúmeras marcas corpóreas da violência entre travestis é feita também por Kulick (1998, p 29-35) e Benedetti (2000, p. 38)
} 
Em um determinado momento começaram a falar de cicatrizes no corpo e várias começaram a mostrar as suas. Fiquei completamente chocado com a quantidade e a extensão das marcas de facadas e tiros, que praticamente todas tinham.

Se refletirmos sobre o significado destas, podemos entendê-las como uma escrita sobre o corpo. Clastres (2003), em ensaio de 1973, mostra ser comum nos ritos iniciáticos de diversas sociedades tribais os procedimentos extremamente dolorosos que deixam marcados os corpos de quem a eles se submete. Interpreta tais cicatrizes como uma memória social, como um obstáculo ao esquecimento de que se é membro de uma dada sociedade e de que se é igual aos demais membros da mesma (p. 197204). No caso das travestis investigadas, tais marcas parecem dizer justamente o contrário: a de que estas não fazem - ou não deveriam fazer - parte da mesma sociedade que os demais integrantes desta. Parafraseando Clastres $^{3}$, a mensagem sobre o corpo de cada uma delas carrega o significado de que "Tu não és um dos nossos e não te esquecerás disso".

\section{Os “alibãs” (polícia)}

A história da homossexualidade, a partir do século XIX, é marcada pelas concepções médicas e jurídicas, que associavam-na ao mesmo tempo como uma doença e como uma conduta condenável, passível de punição. Realidade comum ao mundo ocidental, esta situação não era diferente no caso brasileiro. Historiadores da homossexualidade no Brasil, como Trevisan (2000) e Green (2000) descrevem longamente a perseguição aos homossexuais aqui ocorrida, em especial àqueles considerados mais femininos. Se a sodomia foi descriminalizada desde a promulgação do Código Penal Imperial de 1830, tentativas constantes foram feitas, durante toda a primeira metade do século XX, para incluir a homossexualidade como algo, por si só, passível de punição (Green, 2000, p. 219). Embora tais tentativas não tenham se concretizado, mostram que a homossexualidade permaneceu no limite de ser considerada uma conduta criminosa, o que facilitava a prisão de indivíduos com

\footnotetext{
${ }^{3}$ Clastres (2003) considera que subjacente às marcas corporais adquiridas nos ritos entre os Guayaki está a mensagem "Tu és um dos nossos e não te esquecerás disso" (p. 201)
} 
práticas homoeróticas sob diversas acusações, principalmente o conhecido "atentado ao pudor" (p. 219). Quando escapava da prisão, não era raro um homossexual acabar por ser internado em um hospital psiquiátrico, às vezes a pedido da própria família, como mostra Cunha (1986), em sua história do Juquery (p. 103 e 156-7).

Realidade semelhante viveram as prostitutas na história brasileira. Como mostra Rago (1991), no período compreendido em sua análise (1890-1930), eram comuns as referências de criminologistas, médicos e policiais à criminologia de Lombroso, que associava a prostituição e a criminalidade, de forma a estabelecer uma identidade entre as mesmas ( $\mathrm{p} \mathrm{160-1}$ ) $^{4}$. A alternância de períodos de maior repressão policial à prostituição com períodos de maior tolerância, como o atual, não significa que esta associação não continue presente no imaginário social, uma vez que até hoje "subterfúgios legais, tais como o atentado ao pudor ou o escândalo público, têm sido utilizados como álibis para o enquadramento legal do exercício da prostituição", como mostram Guimarães e Merchán-Hammann (2005) em sua análise da prostituição feminina em diferentes cidades brasileiras (p. 526).

Não é difícil imaginar a intensa repressão policial a que foram submetidas as travestis desde seu surgimento como grupo social, no universo da prostituição. Simultaneamente "bichas" e "putas", as travestis passaram a ser um alvo privilegiado de contenção por parte dos encarregados de "manter a ordem". O final dos anos 70, por exemplo, foi um momento de especial perseguição policial às mesmas, recordado por algumas travestis mais velhas do Grupo. Este período, correspondeu a um momento de intensa repressão a prostitutas, travestis e homossexuais na região central de São Paulo, coordenado pelo delegado Richetti ${ }^{5}$, figura que aparecia como a encarnação da violência policial no discurso delas, direcionado às travestis mais jovens, quando estas se queixavam da mesma: "Vocês não sabem como era na época do Richetti !"

\footnotetext{
4. Para a mesma autora, a violência era um elemento comum no universo da prostituição feminina (p. 231$)$

${ }_{5}$ Tal perseguição e a reação de vários movimentos sociais, bem no momento da abertura política no Brasil, é descrita por Trevisan (2000). Perlongher (1987a) refere-se à intervenção do delegado Richetti, que tem seu auge em 1980, como uma proposta assumida de confinamento e proibição ao trottoir de prostitutas e travestis (p. 92-7)

${ }^{6}$ A impressão das travestis mais velhas do Grupo era de que a violência policial havia diminuído na década de 90, se comparada ao final da década de 70 e à de 80, mesmo sendo ainda intensa.
} 
A relação das travestis investigadas com a polícia era bastante complexa. Estas diferenciavam os policiais "do bem" e "do mal". Os policiais "do bem" eram descritos como aqueles que mantinham relacionamento próximo com elas, muitas vezes também sexual, e que limitavam sua ação a coibir o que elas mesmas consideravam "abuso", como a nudez excessiva, a venda de drogas e os roubos e furtos. Muitos destes costumavam avisá-las de alguma "batida" que fosse ocorrer em algum ponto de prostituição. Por outro lado, os policiais "do mal" eram descritos como aqueles que acharcavam as travestis, com interesses econômicos, e associavam a ação policial à transfobia, se utilizando de métodos violentos de repressão. Alguns episódios de violência policial por elas descrito se configuravam como práticas de tortura:

\begin{abstract}
As travestis estavam revoltadas com um batida policial na região da [...] Várias foram levadas de camburão para a Delegacia. A e F contaram que foram levadas para a Serra da Cantareira e deixadas nuas, no meio da estrada, depois de terem sido humilhadas de várias formas. A. disse que no caminho foi obrigada a fazer sexo oral como um morador de rua enquanto os policiais riam. Muitas histórias passadas de perseguição policial foram retomadas, entre elas algumas que sugeriam um interesse erótico dos policiais pelas travestis, em situações que misturavam violência e maus-tratos com demandas de ordem sexual por parte dos mesmos, em serem “chupados' ou até mesmo penetrados por elas?.
\end{abstract}

Em seu estudo a respeito da violência contra homossexuais em São Paulo, Spagnol (2001) dedica grande parte de suas descrições à violência de policiais direcionada a travestis. Alguns dados mostram de forma clara a transfobia entre eles. Da frase de um comandante da PM, "se eu pudesse, mataria todos !" (p. 36) às descrições das blitzs como "limpeza" (p. 36 e 38), das estratégias de pressão aos clientes, pela anotação das placas dos automóveis (p. 39) à descrição do caso de um policial assassino serial de travestis (p. 143-164), o autor deixa claro que a violência policial parece não ser exceção, mas sim a regra no trato com tal segmento da população.

\footnotetext{
7 A explicação de que o preconceito exacerbado era causado por conflitos psíquicos relacionados à falta de aceitação da própria homossexualidade era tida como verdade absoluta entre as travestis estudadas. Os inúmeros exemplos que deram convenceram-me que tal hipótese não é desprezível - embora por si só não explique a violência a elas direcionada. O argumento da "bicha enrustida" para explicar a "transfobia" é coerente com as teorias psicológicas que utilizam o conceito de projeção para explicar o preconceito.
} 


\section{Roubos e furtos}

É importante ressaltar que a crítica às instituições policiais e às abordagens teóricas que associam homossexualidade e prostituição à criminalidade não podem obscurecer o fato de que muitas travestis acabam por recorrer com frequência a atividades ilícitas, associadas ou não à prostituição. Assunto pouquíssimo descrito nos estudos sobre travestis ${ }^{8}$, sua abordagem se torna importante para uma compreensão efetiva de seu processo de formação identitária.

Os furtos e roubos aos clientes entre as travestis pesquisadas eram uma consequência óbvia do processo de pauperização pelo qual algumas passavam. Isoladas de outros grupos sociais, sem relações de apoio, sem reservas financeiras adequadas para os períodos de menores ganhos, elas se utilizavam dos roubos como estratégia frequente para possibilitar a satisfação, na maior parte das vezes, de necessidades imediatas, como alimentação e moradia.

O recurso às atividades ilícitas como fonte de renda pode também ser visto como consequência de uma certa associação estabelecida entre os mercados informais como o da prostituição - e os ilícitos - como o dos roubos e do tráfico de drogas. Misse (1999) observa ambos se expandindo simultaneamente no Rio de Janeiro a partir da década de 70 , como consequência da precarização do trabalho e do aumento da desigualdade de classes, e considera que a ausência de regulação por parte do Estado faz com que estes mercados se utilizem da violência como um recurso comum (p. 2857).

As travestis investigadas dedicavam boa parte de seu tempo e conversas ao tema dos roubos e furtos. No entanto, tal assunto demorou a aparecer nele de forma significativa: ocorreram, no início, apenas algumas referências àquelas que roubavam,

\footnotetext{
8 As travestis do Grupo referiam que roubos e furtos de (possíveis) clientes eram uma realidade em praticamente todas as grandes cidades brasileiras, com exceção do Rio de Janeiro, onde havia uma forte aliança entre a polícia e as próprias travestis no sentido de evitar que tal fato ocorresse, o que era motivado, segundo elas, pela proteção aos turistas.Apesar disto, só é descrito, resumidamente, por Kulick (1998), entre as travestis de Salvador, e por Ferreira (2003), entre as de Belém.
} 
afugentando os clientes em consequência ${ }^{9}$. Analisando tal fato, retrospectivamente, penso que tal inibição se deveu principalmente à minha postura pessoal como coordenador naquele momento, de condenação de tais práticas, justamente em função da consequência citada e da violência e perseguição policial que acarretava. Tal postura mudou gradativamente, no entanto, à medida em que fui percebendo que tal realidade era por demais incorporada pela maioria delas, o que me fez aceitá-la como algo praticamente intrínseco às travestis de baixa renda. Passei a deixá-las falar sobre o tema sem emitir julgamentos, o que favoreceu a expressão do mesmo por parte das delas. Em alguns momentos, contudo, algumas travestis que estavam começando a frequentar os encontros estranhavam que as demais falassem sobre tais temas na minha presença, o que denotava um acordo tácito entre elas de que tais assuntos não deveriam ser comentados na presença de quem não era "do meio"10:

Percebi em certo momento que uma novata se virou para J. [em meio a uma discussão sobre roubos] e disse baixinho para ela não falar algo na minha frente. J. respondeu alto que não havia problema, que ela podia falar tudo que quisesse, que eu não ia criticar ninguém.

A abordagem da questão passou, a partir desse momento, a ser centrada na proposta de redução de danos, o que envolvia a discussão de estratégias para que as travestis não precisassem roubar com tanta frequência, minimizando-se, dessa forma, os prejuízos potenciais que tais práticas traziam.

As modalidades de roubo e furto de clientes mais comuns entre elas eram três, denominadas de "beijo", "grude" e "puxar a chave". Além destas, haviam alguns golpes

\footnotetext{
${ }^{9}$ Ferreira (2003) considera os roubos um dos principais motivos da diminuição alegada da clientela pelas travestis de Belém (p. 91)

${ }^{10}$ Esta evitação em se falar do tema pode ajudar a explicar o porquê este é pouco abordado em outros estudos sobre travestis. Outra explicação possível é o fato de alguns estudiosos terem uma postura "militante", de defesa das travestis, o que faz com que uma descrição deste aspecto, comum em suas vidas, possa contribuir para estigmatizá-las. Uma terceira possibilidade é tal expressão ter sido facilitada pelo fato de elas me considerarem um "bofe" (homem heterossexual). Se eu não era tido como um interlocutor interessante em assuntos considerados femininos, como os relacionados aos cuidados com a beleza, talvez eu pudesse sê-lo em relação a um tema "masculino", como era o da violência. Os outros pesquisadores, em sua maior parte mulheres ou homens que se identificavam como homossexuais junto às travestis, talvez fossem tidos como bons interlocutores para assuntos mais "femininos", dificultando a expressão dos conteúdos citados.
} 
utilizados, menos frequentes, como algumas variações do "suador" e do "Boa Noite Cinderela". ${ }^{11}$

O "beijo" envolvia o furto de dinheiro e/ou cartões de crédito ou bancários do cliente $^{12}$. Era feito durante o ato sexual propriamente dito, geralmente no próprio carro do cliente, em drive-ins, momento no qual a travesti vasculhava sua carteira nos bolsos, debaixo do banco do carro ou em outros esconderijos comuns.

"Beijar" era considerado por algumas delas uma "arte", pois implicava em grande habilidade, para o cliente não perceber o furto:

P. [travesti muito frequente no Grupo, especialista em "beijo"] disse que nunca havia sido “pega”. Disse a ela que duvidava de tanta habilidade. No meio do encontro várias travestis começaram a rir e perguntei os motivos. P., que estava sentada duas cadeiras à minha direita, mostrou minha carteira, que tinha pego em minha bolsa, a qual tinha ficado o tempo todo do meu lado. Fiquei surpreso com sua rapidez.

Para garantir o sucesso da operação e ainda ganhar um extra, a travesti, depois do "beijo", costumeiramente dava uma bronca enorme no cliente quando este se percebia sem dinheiro, na hora do pagamento do "programa". Exigia que o mesmo fosse sacar dinheiro em algum posto bancário ou que voltasse para pagar no dia seguinte. A bronca neste caso parecia servir para desconcertá-lo, fazendo-o pensar que havia perdido o dinheiro ou tivesse sido furtado em outro local.

Outra modalidade muito utilizada era o "grude"13. Este correspondia entre elas à utilização dos mesmos mecanismos de "escândalo" e de ameaça de uso da violência citados no capítulo anterior. Neste caso, porém, não eram estratégias para se conseguir um pagamento considerado adequado, mas sim para se roubar alguém. O "grude" era, em função de seu objetivo, claramente diferenciado, por elas, do castigo financeiro

\footnotetext{
${ }_{11} \mathrm{O}$ primeiro envolve o furto do cliente por uma outra pessoa, durante a relação sexual com o profissional do sexo. O segundo implica em fazer o cliente ingerir algo que o faça dormir - ou o deixe sem poder de reação - enquanto se furta ou rouba o mesmo. As travestis descreviam diversas variações dos dois, que eram, às vezes, inclusive misturados. O "Boa Noite Cinderela", por exemplo, era mais frequentemente realizado pela alcoolização excessiva do cliente.

12 Também citado por Kulick (1998, p 153)

${ }^{13}$ Citado por Kulick (1998, p 154)
} 
considerado merecido, que era impingido ao cliente que as humilhava, solicitando descontos, por exemplo. Podia envolver alguém que havia pago pelo programa a quantia combinada ou que ainda estava negociando o preço de um programa. Uma estratégia comum para "grudar" era a de se pedir uma "carona"e ameaçar a pessoa no caminho $^{14}$.

Como envolvia um enfrentamento direto com o (possível) cliente, o "grude" envolvia riscos maiores, principalmente se este estivesse armado. Algumas travestis pesquisadas não "grudavam" - ou o faziam raramente - em função do medo da reação que poderia provocar. Para "grudar", consideravam que a travesti deveria ser corajosa:

\footnotetext{
Na discussão [sobre o consumo excessivo de álcool e drogas] B. contou que só bebia excessivamente às terças-feiras. Achei estranho tal padrão de consumo. Mais tarde revelou os motivos da preferência por este dia: era seu dia de "grudar" e o álcool era necessário para lhe dar a coragem que precisava.
}

A terceira modalidade entre as mais utilizadas era a de "puxar a chave". Tal prática envolvia uma aproximação do automóvel do (possível) cliente pelo lado do passageiro e um "mergulho" rápido para retirar a chave do contato. A chave, neste caso, só era entregue mediante um certo pagamento, que aquele quase sempre fazia, por medo de ser agredido ou ter seu carro amassado ou riscado, o que era comumente feito se o pagamento não fosse efetuado. A exemplo das outras modalidades, o "puxar a chave" envolvia o conhecimento das diferenças entre os automóveis ${ }^{15}$ e uma técnica precisa:

V. contou no Grupo que tinha tentado "puxar a chave” do carro de um cliente e que não conseguiu tirá-la. O cliente riu de sua falta de jeito e $\mathrm{V}$. disse que ficou envergonhada e que nunca mais tentaria fazê-lo de novo. Várias travestis riram e P. lhe deu dicas de como

\footnotetext{
${ }_{14}$ Para Misse (1999) a extorsão, ao agir sobre um bem privado valorizado - como a liberdade do corpo e a segurança pessoal do extorquido - tem sua lógica econômica baseada em uma relação extra-econômica (p 292).

${ }_{15}$ Como consequência do fato da grande parte de seus clientes as abordarem de carro, as travestis do Grupo tinham uma grande capacidade de identificar os diferentes modelos e marcas. Constantemente se referiam a algum cliente pela marca e cor de seu carro.
} 
deveria girar a chave. A. falou porém de alguns modelos de carro que tinham mecanismo diferentes.

A exemplo do dinheiro ganho com a prostituição, o obtido com os roubos e furtos era também considerado um dinheiro "maldito", que "entrava e saia fácil", o que as mantinha na necessidade de novos "golpes", mesmo quando conseguiam uma quantia elevada em alguma destas ocasiões. Zaluar (2004) observa tal representação do dinheiro também entre "bandidos" cariocas, que justificavam desta forma a necessidade constante de continuar praticando atos ilícitos (p. 257-8). ${ }^{16}$

Quando percebiam que o cliente era potencialmente agressivo, as travestis evitavam durante um certo período frequentar o mesmo ponto de prostituição e migravam para outros. Outras faziam o processo inverso: buscavam pontos distintos para roubar, mantendo o seu para a prostituição. Obviamente isto só poderia ser feito em São Paulo ou em outras metrópoles que tem várias regiões de prostituição travesti. Mas mesmo nestas, elas podiam ficar visadas após algum tempo, tornando necessária a mudança para outra cidade. Este é, como vimos, um os fatores que explicam a constante migração de travestis pelas grandes cidades brasileiras.

A resposta aos roubos e furtos era algumas vezes bastante violenta. Eram comuns as histórias de clientes que voltam armados procurando as travestis de que foram vítimas ${ }^{17}$ :

Hoje todas estavam assustadas. Contaram que havia uma carro preto suspeito circulando pela Av. $[\ldots]$ e que achavam que estavam procurando por alguma travesti da área, segundo o que uma outra travesti teria comentado. Achavam provável que fosse um cliente que tinha sido roubado por alguma delas e que veio para "acertá-la"

\footnotetext{
${ }^{16}$ Eram raras as vezes em que as travestis do Grupo "aproveitavam" o dinheiro conseguido em uma destas circunstâncias para a realização de algo que ambicionavam. Lembro-me somente de uma vez em que isto ocorreu: ocasião em que uma travesti aproveitou o dinheiro obtido desta forma para colocar uma prótese de silicone nos seios.

17 Durante o período de existência do Grupo, pelo menos duas travestis que o frequentavam foram assassinadas por clientes em busca de vingança. Em ambos os casos, segundo os relatos, o assassino escolheu a vítima "errada", confundindo-a com outra. Isso evidenciava que a prática de roubos gerava problemas para o grupo como um todo e não somente para a travesti que os praticava.
} 
Hoje o assunto foi o assassinato de P. [travesti que já tinha vindo ao Grupo uma ou duas vezes]. Segundo elas, P. foi morta por engano, confundida com outra travesti loira. Acham que o assassino não achou a outra e acabou matando-a "para não perder a viagem", porque ambas eram muito diferentes

A violência dos clientes era bem mais temida do que a policial, em virtude de ser muitas vezes mortal. Se eram uma resposta dos clientes a pequenos golpes, roubos e furtos por parte delas próprias, o grau de violência empregado e o desejo de humilhação das travestis implícito nos atos sugeria também a transfobia à qual nos referimos $^{18}$. Os inúmeros assassinatos de travestis no Brasil, quase todos crimes sem investigação e punição dos responsáveis, são descritos por Mott (2000)

Alguns clientes denunciavam o roubo à polícia, sendo este um dos principais motivos de prisão de travestis. Mas alguns, segundo elas, "gostavam" de ser roubados e continuavam frequentando o mesmo ponto, às vezes na mesma noite, esperando novo roubo. Em sua pesquisa com michês de São Paulo, Perlongher (1987a) observa que a agressividade presumida nos michês é um dos grandes atrativos por parte da clientela, por remeter a uma idéia de hiper-masculinidade que excita os clientes, que nesse caso algumas vezes até apreciam atos violentos ou roubo por parte dos michês. Como explicar o mesmo fenômeno no caso de travestis pesquisadas e seus clientes ? Por detrás das roupas e corpo feminizados delas, há o mesmo desejo por uma virilidade violenta da parte dos clientes ? Ou há um desejo de auto-punição deles pela atração despertada pelas travestis ? Ou ainda, trata-se de um comportamento masoquista clássico $^{19}$ ? As próprias travestis investigadas não conseguiam entender este comportamento e referiam-se de forma jocosa ao mesmo, aproveitando a ocasião para ganhar algum "extra".

\footnotetext{
${ }_{18}$ Uma outra explicação para a resposta por vezes desproporcional dos clientes é o fato de se sentirem enganados por "bichas". Isso poderia fazê-los se sentir particularmente humilhados, em virtude de ficarem em um lugar submisso.

19 Em seu estudo, Perlongher (1987a) também considera que o gosto dos clientes pelo perigo se aproxima do masoquismo, mas nota que seu desejo parece ser mais pela humilhação do que pela dos física (p. 221)
} 


\section{A "pedra" (crack)}

Os vários motivos que levavam as travestis a uma situação de penúria motivando um incremento das atividades ilegais - foram descritos no capítulo anterior. Um deles, porém, por sua importância, merece um item específico neste estudo: o (ab)uso de substâncias psicoativas ${ }^{20}$

O álcool era de uso muito frequente entre elas. Muitas só conseguiam trabalhar "colocadas"21, uma vez que isso as permitia, segundo relatavam, vencer a timidez e ficar mais expansivas com os clientes, além disso garantir maior proteção contra o frio, nos meses do ano em que este se agravava. Apesar disto, não pareciam apresentar sinais de dependência do mesmo, com raríssimas exceções. A maconha, referida por elas como "taba" era também bastante utilizada, algumas vezes como uma estratégia de redução de danos, em momentos de "fissura" em relação ao crack. Tais substância não eram problematizadas por elas, ao contrário do que ocorria com a cocaína e com seu derivado, o crack.

As travestis estudadas eram unânimes em afirmar que a disseminação do crack em São Paulo, na década de 90, foi um fator importante para o aumento de violência e roubos direcionados aos clientes. Aquelas que faziam uso constante do crack, que não eram poucas, estavam quase sempre entre as que mais "beijavam", "grudavam" ou "puxavam a chave". O dinheiro obtido desta forma era quase sempre revertido todo para a compra do produto, mantendo-as em uma situação de penúria econômica. Tais travestis eram referidas como "nóias" ou "noiadas", termo comum para os usuários de crack na região central de São Paulo

\footnotetext{
20 Embora ao termo "dependência química” seja o mais utilizado atualmente para se referir ao uso e dependência que estas substâncias geram, tem sua origem por demais associada a uma visão neuropsiquiátrica, o que leva ao enfoque da questão em uma perspectiva um tanto quanto universalizante. Daí a opção pela sua não utilização neste estudo.

21 Termo mais utilizado entre elas para se referir a quem ingeriu bebida alcoólica. Ferreira (2003) observou de forma semelhante ser esta uma necessidade constante entre as travestis que pesquisou (p. 73)
} 
Se em relação ao álcool ou à maconha não havia sinais de dependência visíveis, o mesmo não se pode dizer em relação ao crack. Algumas mostravam sinais claros de abstinência do uso ${ }^{22}$ - a chamada "fissura". A própria discussão da "pedra", termo de referência mais comum ao crack, levava muitas a manifestá-la, pela imitação frequente do gesto do consumo - acendendo imaginariamente um cachimbo com um isqueiro, aspirando fortemente o ar. ${ }^{23}$

O ab(uso) do crack fazia com que algumas delas passassem a vendê-lo ou repassá-lo (como "avião") aos clientes ou outros usuários. Esta era uma estratégia que Ihes permitia utilizar parte das "pedras" adquiridas ${ }^{24}$ :

T. contou que no dia anterior uma pessoa solicitou a ela que fosse comprar duas pedras de 10 [em meados de 2002, uma pedra pequena custava 5 reais e uma maior 10 na região central de São Paulo]. Ela pegou o dinheiro, comprou as duas e as dividiu, ficando com duas para ela.

A instituição em que o Grupo se reunia ficava próxima à área conhecida como "Crackolândia", na região da Santa Efigênia, zona central de São Paulo. Por congregar simultaneamente um mercado de prostituição, possibilitado pela presença de inúmeros hotéis baratos, e o comércio do crack e outras substâncias psicoativas, tal área permitia um envolvimento muito próximo de várias travestis com estas substâncias ${ }^{25}$. Por causa da repressão policial ao comércio e uso do crack, muitos hotéis proibiam a presença de clientes desacompanhados por um período curto de tempo, em virtude justamente da desconfiança em relação ao provável uso da substância. Isso fazia com que muitos

\footnotetext{
${ }_{22}$ Por ter trabalhado durante um ano em uma instituição para tratamento da dependência gerada por substâncias psicoativas, acabei adquirindo um certo "olhar" para identificá-la.

${ }_{23} \mathrm{Um}$ dos aspectos que as incomodava particularmente em relação ao crack era em relação ao emagrecimento que este gera com o uso contínuo, em função de um de seus efeitos mais comuns ser a perda do apetite. Como vimos nas considerações a respeito da AIDS, a busca por um corpo mais feminino entre elas estava associado a ter formas corporais mais arredondadas, o era impossibilitado pelo emagrecimento.

${ }^{24} \mathrm{O}$ fato de haver um associação frequente entre mercados informais e ilícitos certamente ajuda a explicar a aproximação frequente da prostituição com o uso de substâncias ilícitas, mas é importante considerar também que ambos os mercados estão relacionados diretamente ao prazer, o que faz com que os clientes das travestis sejam frequentemente usuários destas substâncias.
}

${ }^{25}$ Mais recentemente a mesma região tem sido alvo de políticas públicas no sentido de revitalizá-la. 
usuários buscassem travestis ou prostitutas como "acompanhantes", tendo o intuito simultâneo ou exclusivo de fumar crack. Algumas travestis referiram ter sido este mecanismo que levou-as à dependência deste. Este mesmo processo levou outras a entrar diretamente no tráfico, passando a oferecer e vender as "pedras" aos usuários.

\section{A prisão}

Era significativo o número de travestis do Grupo que já tinham sido condenadas por algum tipo de delito e que haviam passado algum tempo cumprindo pena, isso sem considerar o fato que a quase totalidade delas já havia sido detida por um ou alguns poucos dias, sob a frequente acusação de "atentado ao pudor" 26 . Lugares quase esquecidos nos estudos sobre travestis| ${ }^{27}$, as delegacias e prisões tinham um lugar relevante, porém, na socialização e consituição identitária das travestis investigadas.

A detenção temporária, que envolvia muitas vezes passar a noite em alguma delegacia, era uma constante entre elas. Motivada na maior parte das vezes pela reclamação de moradores, em virtude de atos considerados obscenos, tal detenção, na maior parte das vezes, segundo elas, era feita por "atentado ao pudor" ${ }^{28}$, com as

\footnotetext{
${ }^{26}$ As travestis estudadas se referiam como "atentado ao pudor" a qualquer ato considerado obsceno, como, por exemplo, nudez excessiva. No Código Penal Brasileiro, porém, o termo "Atentado violento ao pudor" - artigo 214- refere-se a todo o ato pelo qual uma pessoa, mediante violência ou grave ameaça, constrange outra pessoa a praticar ou permitir que com ele se pratique ato libidinoso diverso da conjunção carnal. O artigo 233, por outro lado, conceitua o "ato obsceno", definindo-o da seguinte forma: "praticar ato obsceno em lugar público, ou aberto ou exposto ao público". Essa confusão é bastante comum, segundo alguns advogados com quem conversei, e se deve aos códigos antigos e ao fato do artigo 233 situar-se em um Capítulo do Código denominado "Do Ultraje Público ao Pudor"

${ }^{27}$ Não pude encontrar estudos disponíveis sobre a situação de travestis nas prisões. O estudos sobre travestis já citados não fazem referência às vivências prisionais.

${ }^{28}$ Como vimos anteriormente, temos que considerar que aquilo que é considerado obsceno para elas é diferente dos padrões sociais hegemônicos. Isso não significa, no entanto, que não existam de fato certos abusos neste sentido, ainda que reconheçamos que o "atentado ao pudor" é muitas vezes um subterfúgio para prendê-las sem acusação alguma. Algumas travestis do Grupo, que defendiam o estabelecimento de uma boa relação com os moradores, questionavam as colegas que se mostravam excessivamente nuas e/ou que praticavam relações sexuais ao ar livre, em frente às residências. Os argumentos utilizados contra os moradores das regiões onde se prostituíam, que se queixavam destas práticas, se referiam muitas vezes à hipocrisia dos mesmos, uma vez que alguns eram identificados como clientes ocasionais.
} 
travestis sendo liberadas no dia seguinte. Entre elas, de tão comum, tal prática era referida como "dormir na delegacia".

Nas noites passadas em delegacias, era comum que realizassem algum "programa" com outra pessoa detida. Havia, porém, a possibilidade de abuso sexual por parte dos outros presos, principalmente se a mesma tivesse sido presa sem a companhia de outras travestis. Tal possibilidade era utilizada como instrumento de pressão ou como simples "castigo" por parte de policiais ${ }^{29}$. Não eram incomuns outra estratégias com a mesma finalidade, como obrigá-las a fazer a faxina da delegacia ${ }^{30} \mathrm{e}$ ameaçá-las a "assinar o artigo".

"Assinar o artigo", isto é, ser acusada formalmente pelo "atentado ao pudor"31 ou por outro motivo era algo bastante temido por elas. Se nas delegacias haviam maustratos, estes eram muito menores do que os que ocorriam no final da década de 70 e na década de 80 , segundo aquelas mais velhas presentes aos encontros ${ }^{32}$. Além disso, configurava-se como uma situação transitória, diferentemente da condenação por algum crime, que as levava às instituições penitenciárias.

Aquelas que já haviam cumprido pena privativa de liberdade tinham más recordações dos presídios pelos quais passaram. Embora pareça haver muita diferença entre eles, a julgar pelo discurso delas, no que diz respeito à aceitação ao grau de aceitação de travestis, no geral elas eram submetidas a diversas formas de discriminação nos presídios, por parte de agentes penitenciários e de outros presos.

J e D. foram visitar A. na Cadeia de Pinheiros [que havia sido presa por tentativa de assalto alguns meses antes]. Disseram que ela estava com o cabelo curso e estava triste com isso. A.

\footnotetext{
${ }^{29}$ Era comum que policiais pressionassem travestis para que estas delatassem suspeitos de ter realizado algum crime. Personagens "da noite”, eram consideradas boas informantes pelos policiais, segundo referência delas mesmas.

${ }_{30}$ Tal castigo em relação a travestis é citado por Trevisan (2000, p. 419). Recordemos aqui que esse castigo era o mesmo aplicado ao homossexuais efeminados no início do século XX no Brasil.

${ }^{31} \mathrm{O}$ que, na verdade, corresponderia, como vimos, ao “ato obsceno” do Código Penal

$32 \mathrm{Na}$ década de 70 era constante o recurso à auto-mutilação para conseguirem ser liberadas da delegacia, feita principalmente por cortes no braço. Algumas travesti, mais velhas, apresentavam cicatrizes referentes a esta prática, que, segundo elas, não existia mais.
} 
contou a elas que estava "dando mais que chuchu na cerca" para se virar na prisão e que pediu aos funcionários para que tentassem mudá-la de local”

Welzer-Lang (2001) considera que as prisões reproduzem a imagem hierarquizada das relações entre homens e mulheres, o que pode ser observado na forma como alguns segmentos de homens - considerados mais femininos - são tratados por outros - tidos como mais masculinos - o que faz com que

\begin{abstract}
os jovens homens, os homens localizados ou designados como homossexuais (homens ditos efeminados, travestis....), homens que se recusam a lutar, ou também os que estupraram as mulheres, dominadas, são tratados como mulheres, violentados sexualmente pelos "grandes homens" que são os chefões do tráfico, roubados, violentados". Freqüentemente, eles são apenas colocados na posição da "empregada" e devem assumir o serviço daqueles que os controlam, particularmente o trabalho doméstico (limpeza da célula, da roupa...) e os serviços sexuais.
\end{abstract}

Embora a análise de Welzer-Lang (2001) apresentada seja excessivamente generalizante, tal descrição parece corresponder em uma certa medida àquela descrita pelas travestis do Grupo que já ficaram presas por um certo período ${ }^{33}$. Mas a submissão delas não era total como o trecho sugere, uma vez que, quando juntas, podiam estabelecer espaços de resistência frente aos vários segmentos da população carcerária.

Duas obras voltadas à descrição do Complexo Penitenciário do Carandiru, recentemente demolido, mostram as relações das travestis com o demais presos como algo contraditório. Em seu best-seller "Estação Carandiru", Varella (2003) identifica. as travestis ali presas como vindas todas da camada mais pobre da população. No presídio ficavam geralmente em celas especiais, mas havia casos de travestis espalhadas pela penitenciária, e eram identificadas como perigosas,

\footnotetext{
${ }^{33}$ Em seu estudo no "Carandiru", no final da década de 70, Ramalho (1983) descreve a diferença entre a figura da travesti e a do "boy", que era feito "na marra", ou seja, forçado a manter um relacionamento com algum outro preso, ocupando o lugar passivo. Alguns "boys", no entanto, acabavam se prostituindo no interior do presídio, algo motivado, principalmente, pelo consumo de drogas. As travestis, por serem mais disputadas pelos presos, geravam conflitos entre eles, o que demandava sua permanência em celas separadas (p. 49-56).
} 
independentemente do que tinham feito. Referidas como "mulheres de cadeia"34, ocupavam, contudo, um lugar específico na hierarquia entre os diferentes segmentos de presidiários, um vez que não era tolerado que cometessem atos violentos relacionados aos bandidos "homens". O documentário "O Prisioneiro da Grade de Ferro", realizado por presidiários do mesmo Complexo, mostra a mesma ambivalência. A travesti que narra a filmagem da "Rua das Flores", local que concentrava parte das travestis dali, relata: "Nós que somos bichas não pode quase nada. Quem pode é só os homens. Nós pode ficar quietinha ficar quieta no lugar da gente.". Ao mesmo tempo, porém, refere que a restrição geográfica a que as travestis ficam submetidas se deve às brigas que causam em outros setores da penitenciária, o que mostra que não há uma submissão total por parte delas, que reagem muitas vezes à violência sofrida.

\section{O "bandido"}

Algumas lideranças que defendem a legalização da prostituição buscam separar tal atividade das atividades ilícitas, nas quais os segmentos que representam às vezes se envolvem ${ }^{35}$. Isso também ocorria no Grupo, onde algumas travestis que se opunham aos roubos e furtos, minoritárias entre aquelas deste estudo, referiam-se à prática exclusiva da prostituição, somada a eventuais "castigos" aos clientes que as humilhavam, como "trabalhar na moral". Buscavam, nestes termos, se diferenciar das que roubavam e as criticavam abertamente nos encontros, sendo este um campo de tensão permanente entre elas.

É evidente que do ponto de vista político esta distinção se faz necessária, uma vez que é mais provável - ainda que difícil - o apoio da opinião pública à prostituição do que aos roubos e furtos. Mas tal defesa não pode obscurecer a proximidade histórica entre os "mundos" da prostituição, da homossexualidade e do crime, associação esta

\footnotetext{
34 As travestis segundo o autor tem vida sexual muito intensa na cadeia e tem um altíssimo nível de infecção pelo HIV. ,

${ }_{35}$ Em um dos Encontros Nacionais de Prostitutas, segundo uma pessoa presente, Gabriela Leite teria afirmado, com referência às prostitutas que se envolviam em atividades ilícitas, como roubos, furtos e tráfico de drogas, que elas não seriam prostitutas, mas "bandidas" (Comunicação pessoal de Josefa Laurindo da Silva, a "Nina”, em fevereiro de 2002).
} 
facilitada pelo estigma relacionado a todos eles. Tal conjunção é citada na década de 30 por Green (2000), que mostra a prostituição e o crime como respostas possíveis ao desemprego por parte de jovens efeminados e por Barbosa da Silva (2005), que refere o mesmo na década de 50 em São Paulo, como consequência da falta de apoio familiar a estes mesmos jovens (p. 123-4). Em algumas modalidades de prostituição feminina tal associação também parece ser frequente, como mostra Gaspar (1985) a respeito das prostitutas de Copacabana (p. 20, 39, 69 e 91). O crime, desta forma, aparece como uma resposta a uma condição social.

Além da questão financeira, outros elementos podem estar presentes nesta associação. Perlongher (1987a), em seu estudo sobre michês paulistanos na década de 80 , interpreta os roubos de clientes por parte deles como motivados não só pela necessidade financeira imediata, mas também como uma maneira de extravazar a raiva em relação à situação de penúria, algo que fica mais explícito na relação com clientes de maior poder aquisitivo ( 175 e 184). Observa que também são consequência da destruição de laços de solidariedade territorial entre os diversos segmentos que ocupam os mesmos espaços, o que faz com que os relacionamentos passem a ser cada vez mais anônimos (p. 100).

A conjunção entre a prostituição masculina e a criminalidade é também facilitada pela superposição dos territórios da homossexualidade e da criminalidade em algumas grandes cidades. A base espacial comum da prostituição masculina e criminalidade é citada em relação aos michês por Perlongher (1987a, p. 49), em São Paulo, e às travestis por Silva (1993), no Rio de Janeiro, que considera que bandidos e travestis estão imersos em um mesmo circuito de relações informais (p. 87).

Se as que "trabalhavam na moral" incorporavam parcialmente as identidades de prostituta e de malandro no campo ocupacional, propomos considerar aqui que as travestis que se envolviam diretamente em atividades ilícitas se apropriavam também de uma outra identidade nesta esfera: a de bandido. O termo "bandida" era, de fato, algumas vezes utilizado no Grupo como referência às travestis que roubavam.

Consideramos aqui que, a exemplo da identidade da prostituta, a identidade do "bandido" é parcialmente incorporada não somente pela prática em comum - roubar - 
como pela convivência próxima que muitas delas tinham com bandidos. A convivência se dava nos relacionamentos amorosos - muitos "maridos" eram bandidos ${ }^{36}$ - no relacionamento cotidiano com traficantes ou ladrões, que às vezes as ajudavam em roubos a clientes potenciais e, como vimos, nas vivências no sistema prisional.

Adorno (1991) propõe considerar que as respostas institucionais a comportamentos desviantes, como as práticas prisionais, resultam na elaboração de identidade e carreiras criminosas. A reincidência criminal, para o autor, mostra que a separação entre "trabalhadores" e "bandidos" é facilitada pela especialização na prática do crime. Misse (1999) denomina tal processo "sujeição criminal' e considera que a representação de "mundo" ou "submundo do crime" apóia-se na noção de "bandido", que passa a ser diferenciado de outros tipos sociais (p. 41-3). O controle deste submundo exige a demarcação de quem faz parte dele, o que produz a sujeição criminal - passam a haver subjetividades que incorporam a incriminação a elas direcionada, agindo "como se, de algum modo, capturassem a sua definição social, assumindo-a e desenvolvendo-a como sua própria definição" ( p. 47). A transgressão "desliza" para a subjetividade do agressor e passa a ser entendida como algo inerente a ele, como seu caráter, formando uma identidade de "bandido".

Se a identidade de bandido é resultado tanto de atribuição social quanto de incorporação da mesma, como encarar tal processo entre travestis ? Em uma visita ocasional ao "Museu do Crime", próximo ao Campus da USP da Cidade Universitária, observei a foto de uma travesti. A referência da foto não explicitava qualquer tipo de crime cometido: a travesti estava lá pelo simples fato de ser travesti. Isso mostra que estas são objeto de incriminação social por sua própria existência ${ }^{37}$. É possível

\footnotetext{
36 Algumas vezes as travestis e seus "maridos" ou "vícios" se tornavam parceiros de atos infracionais, especialmente o roubo de clientes. A participação exata deles nestes roubos não era relatada. Com relação aos roubos e furtos, mantive sempre uma postura de ouvir o que me contavam, sem perguntar muito além disso. Embora tivesse curiosidade e interesse acadêmico pelo assunto, não posso deixar de reconhecer um certo medo das consequências de ser mal-interpretado, caso perguntasse demais sobre o assunto. A parceria entre travestis e “maridos” nos furtos e golpes é também citada por Benedetti (2000, p 117$)$.

${ }^{37}$ No referido Museu, visitado em outubro de 2005, há uma sala nomeada "Medicina Legal”. Nesta há algumas seções: Suicídios, Homicídios, Necropsia, Exumação, Abortos e Infanticídios e, finalmente, uma denominada "Diversos", que é onde a referida foto se encontra. Nesta última seção, há fotos de um falso pedinte, que simulava problemas físicos, de acidentes de trabalho, de empalamento, de um homem que se
} 
considerar a esse respeito que as travestis tenham progressivamente incorporado a incriminação a que foram historicamente submetidas.

Outro fato a se considerar é a relação que as próprias travestis estabelecem com os "bandidos". Misse (1999) ao falar da sujeição criminal, considera-a como uma "potencialidade de todos os indivíduos que possuam atributos próximos ou afins ao tipo social acusado" (p. 65). Isso equivale a dizer que se há o tipo "ideal” do bandido, há os que dele se aproximam em maior ou menor grau. Para o autor, há uma ampliação da sujeição criminal para os indivíduos e grupos que mantém relações regulares com os que se encontram socialmente sob "exclusão criminal", mas que não são considerados bandidos (p. 233).

Na configuração de sua identidade, para o mesmo autor, os "bandidos" passam a valorizar positivamente a identidade a eles atribuída, originalmente negativa (p. 67). Tal positivação da identidade pode ser percebida, para ele, nas "narrativas de trajetórias, peripécias e façanhas" dos sujeitos criminais (p. 202). Tais narrativas podiam ser observadas entre as travestis aqui pesquisadas, envoltas na demonstração de orgulho pelas habilidades e nos relatos um tanto ostentosos dos golpes aplicados. Aquelas que roubavam chegavam a exibir um certo desprezo em relação às que só "trabalhavam na moral", o que era interpretado por elas como falta de coragem, e não como algo fruto de uma postura mais ética.

Os bandidos eram, como vimos, "maridos" ou "vícios" valorizados pelas travestis, por sua representação de uma masculinidade associada à violência, comum em alguns segmentos populares ${ }^{38}$. Não eram raras as referências entre elas ao "tesão" que estes

acidentou ao tentar voar com um aparelho rudimentar, de um acidente com cobra e da travesti em questão. Esta é mostrada em duas fotos: na primeira está com um vestido e na segunda com o mesmo levantado, mostrando os órgãos genitais masculinos. A legenda refere simplesmente "Travesti (1928)". Como o Museu mudou de lugar várias vezes, não é possível saber a partir de que momento a pessoa em questão passou a ser identificada como "travesti”. O que chama a atenção é que todas as fotos e ícones presentes na Sala referem-se diretamente a crimes e/ou acidentes, com exceção da foto da "travesti" referida.

${ }_{38}$ Zaluar (2004) problematiza a naturalização da associação entre violência e masculinidade, uma vez que as masculinidades hegemônicas se baseiam principalmente no consentimento e aceitação, tornando a violência desnecessária. Mesmo a consideração de que a violência seria típica da masculinidade subalterna ou marginal nega que, mesmo nos segmentos marginalizados, há diferentes concepções de masculinidade (p. 366-7). Nos morros cariocas, porém, observa que o "etos guerreiro", que passa a predominar a partir 
Ihes despertavam. Se a hiper-masculinidade associada ao bandido era algo desejável, a apropriação da mesma identidade pelas travestis não era isenta de contradições, uma vez que a mesma implicava em se colocar em uma posição eminentemente masculina, algo contraditório em um grupo que em outras modalidade de interação busca por um lugar feminino ${ }^{39}$.

do crescimento do tráfico de drogas, faz claramente a associação referida, enfraquecendo outras identidades masculinas que eram valorizadas no local, como a de sambista, de malandro, de jogador de futebol, de pai-de-família (p. 64).

${ }^{39}$ A incompatibilidade entre a figura do "viado" e a do "bandido" é observada também por Misse (1999) 


\section{CONCLUSÃO}

Na proposta de entendimento da identidade social desenvolvida no início deste estudo, consideramos que esta em alguns grupos sociais pode ser compreendida como resultante da incorporação de fragmentos de diferentes identidades sociais por parte de um grupo. Denominamos a identidade resultante deste processo como "colcha de retalhos", pela metáfora de unificar, em um mesmo produto final, elementos por vezes bastante distintos entre si. Consideramos também que a apreensão destas identidades poderia se dar de forma imaginária ou a partir de vivências concretas com outros grupos onde elas estejam presentes.

Conforme analisamos no decorrer deste estudo, a identidade entre as travestis de baixa renda estudadas pode ser entendida como fruto da assimilação de diferentes identidades sociais que foram abordadas em cada um dos eixos especificados - gênero, corpo, trabalho e violência, que, como vimos, se interpenetram em vários pontos.

Nas considerações a respeito do primeiro eixo - gênero - sugerimos que as travestis de baixa renda estudadas eram objeto de intensa discriminação pelo fato de excederem as classificações normativas associadas ao gênero e sexualidade presentes em nossa sociedade. Figuras consideradas "monstruosas" e abjetas, não são apropriadas pelos sistemas de saber e poder estabelecidos, o que suscita sua eliminação, algo que é perceptível nos assassinatos frequentes de travestis, fruto de um sentimento que denominamos transfobia.

Com relação a história de vida comum às mesmas, observamos que estas eram oriundas de famílias de baixa renda, em sua grande maioria, e desde cedo já eram consideradas como "bichas" ou "viados", sofrendo agressões na escola e na própria família em função disso. Ao sair da cidade de origem para a "cidade grande", na expectativa de melhores condições de trabalho e de aceitação social, quase sempre 
tinham como única alternativa a prostituição. Por esta via, entravam em contato com as travestis já "feitas", que as ajudavam na entrada neste novo universo, processo este que corresponde, como vimos, a uma ressocialização.

Vimos também que nas relações afetivas e sexuais com seus companheiros - os "maridos" - as travestis estudadas incorporavam a identidade da mulher submissa, permanecendo geralmente em um posição passiva frente aos mesmos, que muitas vezes as exploravam economicamente, e associando a feminilidade com o sofrimento. Nas relações com os vícios, parceiros ocasionais, porém, mantinham um relação mais igualitária.

No segundo eixo abordado - o da relação com o corpo - consideramos que sua vivência corporal passava por uma percepção do caráter ambíguo do mesmo, o que sugeria que elas não o percebiam como apenas masculino ou feminino. Observamos uma intensa preocupação relacionada à transformação corpórea entre elas, principalmente voltada ao uso de métodos definitivos, como a hormonioterapia e a aplicação de silicone. Consideramos que a busca por um corpo voluptuoso e sedutor correspondia à incorporação de outra identidade por parte das mesmas: a da mulher sedutora, personagem frequente nos meios de comunicação de massa, especialmente no cinema.

Observamos também que nas representações das mesmas a respeito do próprio corpo era comum a concepção de que havia uma "luta" entre os aspectos femininos e masculinos, o que ficava implícito na problematização que faziam da própria "neca" (pênis), da ejaculação e da cirurgia de transgenitalização. Observamos também que a AIDS era percebida como algo que masculinizava seus corpos, sendo este mais um motivo de sofrimento para as portadoras de HIV ou para aquelas que já haviam desenvolvido a doença.

Em relação ao terceiro eixo - o do trabalho - observamos que a prostituição é algo inseparável da constituição das travestis enquanto grupo social. Vimos que as mesmas praticavam principalmente a modalidade do trottoir e que a prostituição travesti em São Paulo rompeu de forma evidente com a territorialização homossexual na cidade, ocupando espaços da prostituição feminina. A atividade em comum, a 
contiguidade espacial e a convivência com prostitutas mulheres levou-as à incorporação de outra identidade em sua "colcha de retalhos": a da "puta".

Consideramos que muitas das características das travestis pesquisadas deviamse exatamente ao fato de serem trabalhadoras autônomas do setor informal da economia. Isto fazia com que, a exemplo de outras modalidades de trabalhadores informais que ocupam espaços públicos, como camelôs, competissem por estes espaços entre si e atraíssem constantemente a rejeição da parte de moradores e comerciantes do local. Observamos que a falta de trabalho formal gerava um encarecimento do crédito e do aluguel para as mesmas. O fato da prostituição ser uma ocupação onde há um intensa valorização da juventude levava as mais velhas, que tiveram quase sempre um processo de escolarização precário, a ter pouquíssimas alternativas profissionais a esta atividade, a maioria delas associada ao próprio universo das travestis. A pauperização pela qual muitas passavam levava a uma competição predatória pelos clientes, o que acabava por fazer com que todas fossem afetadas neste processo e por gerar dificuldades de associação entre elas.

Verificamos, a partir dos discursos das mesmas, uma grande heterogeneidade entre seus clientes $\mathrm{Na}$ relação com estes vimos que as travestis investigadas buscavam por um lugar de domínio, incorporando mais uma identidade, a do "malandro". Pelo uso do escândalo e pela ameaça do uso da força física, combinados aos "truques" da profissão, vimos que as mesmas colocavam frequentemente os clientes na posição de "otários", objeto de exploração econômica da parte delas.

No quarto eixo - o da violência - vimos que as travestis são submetidas a múltiplas formas de violência no decorrer da sua vida, o que foi relacionado ao não reconhecimento de seu direito de existência enquanto grupo social. Em função disso, vimos que historicamente desenvolveram relações tensas com a polícia, o que era patente entre as travestis investigadas.

Em relação à prática de atividade ilícitas, consideramos que as travestis estudadas incorporaram historicamente o processo de incriminação a que foram submetidas. Pela falta de perspectiva profissional e pelos recursos muitas vezes insuficientes vindos da prostituição, vimos que muitas passaram a recorrer aos roubos e 
furtos como estratégia de ganhos financeiros. Descrevemos as três modalidades mais praticadas - o "beijo" , o "grude" e o "puxar a chave", observando que tais práticas contribuíam para o aumento da violência direcionada a elas como grupo social.

Com relação a este eixo refletimos também sobre a importância de considerar o relacionamento com os bandidos e as vivências no sistema prisional como elementos importantes na socialização das travestis pesquisadas. A prática de delitos e o tráfico de drogas - no qual várias se envolviam, em maior ou menor grau, para sustentar o próprio consumo, especialmente do crack - fazia com que as mesmas se aproximassem do "mundo do crime", o que determinava a possível incorporação da última das identidades que consideramos relevante na sua constituição identitária: a do "bandido".

Conceber a identidade das travestis estudadas como uma "colcha de retalhos", como vimos, é distinto de se afirmar que elas eram às vezes "putas", em outros momentos "viados" e em outros ainda "malandros". Significa, ao contrário, dizer que elas eram travestis justamente porque assumiam todas estas figuras. A síntese de elementos contraditórios em uma mesma figura é também metaforizada na figura mítica do dragão, mesmo termo utilizado pelas travestis para designar aquelas que são pobres e/ou tem aparência masculina. Tal figura, embora seja representada de maneira distinta em diferentes mitologias, tem como marca comum a mistura de elementos de diferentes animais, como a cabeça de cobra ou lagarto e a presença de asas e plumas, somados a poderes mágicos e ao hálito de fogo. É entendida como representante de poderes do "bem" ou do "mal" em mitologias distintas, o que sugere uma outra analogia com as travestis, que são tidas como figuras a serem eliminadas, mas que simultaneamente atraem o desejo erótico de muitos, às vezes os mesmos que as agridem.

Ao considerar a identidade das travestis investigadas a partir desta proposta, não podemos correr o risco de reificar as identidades sociais descritas que the deram origem. Algumas delas correspondem a posições de sujeito "ocupadas" de forma significativa e estão também elas em processo de transformação. Observamos estas mudanças no caso da "puta", que se transforma em "profissional do sexo", do "viado", que se torna "gay", nas representações sucessivas da mulher super-sedutora e na "morte" do malandro. 
Da mesma forma, considerar a "identidade travesti" a partir deste modelo não implica em tomá-lo como definitivo em relação ao conjunto final dos fragmentos introjetados e ao peso relativo de cada um deles neste conjunto. Isso significa dizer que talvez os "retalhos" não sejam os únicos a preencher a "colcha" e que cada um deles pode ter "tamanhos" diferentes. No primeiro caso, vimos que outras identidades sociais também podem ser consideradas como tendo alguma importância na formação da identidade das travestis estudadas, como no caso da figura do "nóia" ou do "aidético". No segundo, vimos que, enquanto algumas identidades incorporadas, como a do "viado" e da "puta" são onipresentes entre elas, outras podem ter um peso relativamente menor, como no caso das referentes ao "bandido" e à "mulher submissa"

As observações feitas referem-se, em última instância, a não se tomar tal compreensão de identidade a partir de uma perspectiva essencializante. Como vimos, a identidade é uma categoria útil para análise dos grupos sociais, desde que submetida a um processo de desconstrução da própria categoria, como forma de evitar que seja concebida como algo definitivo. Essa conceituação implica em conceber que a “identidade travesti” está sujeita a oscilações em função do processo histórico, do lugar geográfico em que as travestis se encontram e do segmento de renda a que pertencem. Neste último caso, é possível se considerar que determinados fragmentos identitários, como o do "malandro" e o do "bandido" sejam mais relevantes em segmentos de baixa renda. Conforme observamos anteriormente, o presente estudo visa oferecer uma possibilidade de compreensão em um dado lugar e momento histórico, correspondendo a um retrato de uma "colcha" em permanente construção.

Considerar as identidades sociais descritas como as principais constituintes da identidade travesti implica, também, em reconhecer que tal identidade é fortemente sujeita a tensões. Tensões evidentes entre as identidades masculinas e femininas, mas também dentro dos próprio campo da feminilidade e da masculinidade. Algumas destas foram descritas no transcorrer deste estudo. No campo da feminilidade, por exemplo, exploramos a contradição entre a submissão da "mulher de malandro" e o desejo de domínio presente na figura da "femme fatale", ou o possível desacordo entre ser desejada, como no caso desta última, e ser usada, como no caso da "puta". No campo da masculinidade, observamos a contradição entre a figura do "malandro" e a do 
"bandido" no que se refere às práticas que são por elas aceitas em relação aos clientes, e a incoerência entre a mesma figura do "bandido", representativa de uma masculinidade viril e violenta e a do "viado", tida como passiva e "covarde". As contradições entre as identidades masculinas e femininas descritas eram ainda mais intensas. Se aceitavam o "marido" malandro, incorporando a figura da "mulher submissa", na relação com os clientes se colocavam como "malandros", mantendo-os em uma posição complementar à sua - a de "otários" - e se revoltando contra aqueles que tentavam deixá-las em um lugar submisso.

Os "nós" e "costuras"da "colcha de retalhos" são certamente dificultados pelas tensões citadas, que se configuram desta forma como uma marca constituinte da própria identidade travesti. Ser travesti é viver tais contradições cotidianamente, no corpo, na auto-representação, nos relacionamentos duradouros e nos transitórios, e ser cotidianamente punida por isso.

As tensões entre os diferentes fragmentos da identidade travesti a impedem também de se solidificar, de se tornar claramente perceptível, a tal ponto que suscita frequentemente a questão: "afinal de contas, quem é a travesti ?". Os estudiosos que se debruçam sobre o tema se fazem sempre esta pergunta e tentam, como foi observado, descobrir o aspecto fundamental da mesma. As próprias travestis do Grupo não o conseguiam. Tinham a percepção de que havia, sim, algo que as definia o grupo, mas quando inquiridas sobre o que seria este "algo" as respostas eram sempre contraditórias ou evasivas. Dadas as tensões descritas, não haveria como ser de outra forma.

A identidade fraturada, de viado e mulher submissa, super-sedutora e quase sempre puta, às vezes malandro e outras bandido, é de difícil consolidação. Se as travestis de segmentos de renda mais alto, as "deusas", talvez consigam uma aproximação maior com as identidades tipicamente femininas descritas e, por isso, diminuam a contradição, fruto da apropriação de identidades de difícil síntese, as "dragões" tem uma tarefa certamente mais difícil. A construção de uma identidade neste caso traz fissuras evidentes, demandando uma cicatrização de ordem subjetiva ainda mais difícil do que aquela de ordem física fruto das transformações corpóreas e dos atos de violência sofridos. 


\section{BIBLIOGRAFIA}

ABREU, M. Meninas Perdidas. In PRIORE, M. (org). História das crianças no Brasil. SP: Contexto, 1999.

ADORNO, Sérgio. A prisão sob a ótica de seus protagonistas: itinerário de uma pesquisa. Tempo Social; Rev. Sociol. USP, S. Paulo, 3(1-2): 7-40, 1991.

AMÂNCIO, Lígia. Identidade social e relações intergrupais. In: VALA, J. \& MONTEIRO, M. B. (coords.). Psicologia Social. Lisboa: Fundação Calouste Gulbenkian, 1999

ANDRADE, Maria Cristina Antunes. Territórios de vulnerabilidade ao HIV: homossexualidades masculinas em São Paulo. Tese de Doutorado em Psicologia Social. São Paulo, Universidade de São Paulo, 2005.

ARAÚJO JR, José Carlos de. A Metamorfose Encarnada: travestimento em Londrina (1970-1980). Dissertação de Mestrado em História. Campinas, Universidade Estadual de Campinas, 2006

ARENT, Marion. O preço do prazer: uma análise psicossocial do trabalho dos garotos de programa. Dissertação de Mestrado em Psicologia Social e da Personalidade. Porto Alegre, Pontifícia Universidade Católica do Rio Grande do Sul, 1999.

BARBOSA DA SILVA, José Fábio. Homossexualismo em São Paulo: Estudo de um grupo minoritário. IN GREEN, James, N. e TRINDADE, Ronaldo (orgs). Homossexualismo em São Paulo e outros escritos. SP: Editora UNESP, 2005

BARREDA, Victoria e ISNARDI, Virginia. Travestismo y HIV: uma problemática em torno a la diferencia. Disponível na Internet:

http://www.sasnac.org.ar/docs/ciencias_sociales/travestismo_y_hiv.pdf [12 jan. 2007]

BENEDETTI, Marcos Renato. Toda Feita: o corpo e o gênero das travestis. Dissertação de Mestrado em Antropologia Social. Porto Alegre, Universidade Federal do Rio Grande do Sul, 2000.

BERGER, Peter, L e LUCKMANN, Thomas.(1966) A construção social da realidade: tratado de sociologia do conhecimento. Petrópolis: Vozes, 1985.

BIRMAN, Patrícia. Fazer estilo criando gênero: estudo sobre a construção religiosa da possessão e da diferença de gêneros em terreiros de umbanda e candomblé do Rio de Janeiro. Rio de Janeiro: RelumeDumará/Ed UERJ, 1995

BOURDIEU, Pierre. Conferência do Prêmio Goffman: a dominação masculina revisitada. In. LINS, Daniel (org) A dominação masculina revisitada.Campinas: Papirus, 1998 
BRANDÃO, Carlos Rodrigues (org.) Repensando a pesquisa participante. São Paulo, Brasiliense, 1987

BUTLER, Judith. Bodies that Matter: on the discursive limits of 'sex'. New York \& London, Routledge, 1993.

BUTLER, Judith. Problemas de gênero: feminismo e subversão da identidade. Rio de Janeiro: Civilização Brasileira, 2003

CALligaris, Contardo. "Transex" Folha de S. Paulo. Caderno Ilustrada. 18/11/2004

CÂNDIDO, Antônio (1973) Dialética da malandragem. In: O discurso e a cidade. São Paulo: Duas Cidades, 1993

CASSIDY, Clare e TREW, Karen. Identity in Northern Ireland: a multidimensional approach. Journal os Social Issues. Vol. 54, $\mathrm{N}^{\mathrm{o}} 4,1998$, pp. 725-740

CASTRO, R. V. Representações sociais da prostituição na cidade do Rio de Janeiro IN SPINK, M. J. (org). O conhecimento no cotidiano: as representações sociais na perspectiva da Psicologia Social. SP, Brasiliense, 1993

CLASSIFICAÇÃO BRASILEIRA DE OCUPAÇÕES - Ministério do Trabalho. Disponível na Internet: http://www.mtecbo.gov.br/busca/descricao.asp?codigo=5198 [20 dez. 2006]

CLASTRES, Pierre. A sociedade contra o Estado - pesquisas de antropologia política. São Paulo: Cosac\&Naify, 2003

CONNELL, Robert W. Políticas da Masculinidade. Educação\&Realidade, 2O(2): 185-206. jul-dez. 1995

CONNELL, Robert W. La organización social de la masculinidad. IN VALDÉS, T; OLAVARIA, J. (eds). Masculinidad/es: poder y crisis, Santiago, Chile: Isis Internacional, 1997

CUNHA, Maria Clementina Pereira. O espelho do mundo - Juquery, a história de um asilo. Rio de Janeiro: Paz e Terra, 1986.

DA MATTA, Roberto. Carnavais, malandros e heróis: para uma sociologia do dilema brasileiro. Rio de Janeiro: Zahar, 1983.

DOUGLAS, Mary. Pureza e perigo. Lisboa: Edições 70, 1991

DUARTE, Luis Fernando. Da vida nervosa nas classes trabalhadores urbanas. Rio de Janeiro: Zahar/CNPq, 1986

DUVEEN, Gerard. Representations, Identities, Resistance. In DEAUX, K \& PHILOGENE, G. (eds) Social Representations: Introductions and Explorations. Oxford: Blackwell, 2001.

ELlEMERS, Naomi, SPEARS, Russell e DOOSJE, Bertjan. Self and Social Identity. Annu. Rev. Psychol., 2002, 53:161-186, 2002. 
ENGEL, M. Meretrizes e Doutores. SP: Brasiliense, 1988.

ERIKSON, E. Identity, Youth and Crisis. New York: Norton\&Company Inc, 1968

FARINA, Roberto. Transexualismo: do homem à mulher normal através dos estados de intersexualidade e das parafilias. São Paulo: Novalunar, 1982

FAUSTO-Sterling, Anne. Dualismos em duelo. Cadernos Pagu, Campinas, v. 17/18, p. 9-79, $2001 / 2002$

FELDMAN, Sarah. Segregações espaciais urbanas: a territorialização da prostituição feminina em São Paulo. Dissertação de Mestrado em Arquitetura e Urbanismo. São Paulo: Universidade de São Paulo, 1989

FERREIRA, Rubens da Silva Ferreira. As “Bonecas” da Pista no Horizonte da Cidadania: uma jornada no cotidiano travesti. Dissertação de Mestrado multidisciplinar em Desenvolvimento Sustentável do Trópico Úmido. Belém, Universidade Federal do Pará, 2003.

FIGUEIREDO, L. C. Modos de Subjetivação e outros escritos. São Paulo: Escuta/EDUC, 1995

FLORENTINO, Cristina de Oliveira. Bicha tu tens na barriga, eu sou é mulher: etnografia sobre travestis em Porto Alegre. Dissertação de Mestrado em Antropologia Social. Florianópolis, Universidade Federal de Santa Catarina, 1998.

FONSECA JR, Eduardo. Dicionário Antológico da cultura afro-brasileira. São Paulo: Maltese, 1995

FONTENELE, Cláudia Valença. Entre estrelas e passarelas: a condição travesti e seus ritos de apresentação. Dissertação de Mestrado em Sociologia. Fortaleza, Universidade Federal do Ceará, 1999

FOUCAUlT, Michel, (1975). Vigiar e Punir. Trad. Ligia M. Pondé Vassalo. Petrópolis: Vozes, 1987.

FOUCAULT, Michel (1976). História da Sexualidade I: A vontade de saber. Trad. Maria Thereza da Costa Albuquerque e J. A. Guilhon Albuquerque. RJ: Graal, 1988.

FOUCAULT, Michel. Nietzsche, a Genealogia e a História. In: Microfísica do Poder. Rio de Janeiro, Graal, 1979.

FOUCAULT, Michel. Herculine Barbin: o diário de um hermafrodita. Rio de Janeiro: Francisco Alves, 1982a

FOUCAULT, M. (1982B) Sex, power and the politics of identity. In FOUCAULT, M. Ethics, Subjectivity and Truth: The Essencial Works of Michel Foucault, 1954-1984", vol. I; edited by Paul Rabinow. New York, New Press, 1997.

FOUCAULT, Michel. Os anormais. São Paulo : Martins Fontes, 2001

FREUD, Sigmund (1921). Psicologia de Grupo e Análise do Ego. In: Edição Eletrônica Brasileira das Obras Completas de Sigmund Freud. Rio de janeiro: Imago/Z.Movie, 1998. 
FRABLE, Deborrah E. S. Gender, racial, ethnic, sexual, and class identities. Annu. Rev. Psychol., 1997, 48:139-62, 1997.

FREITAS, Renan Springer. Bordel, Bordéis: negociando identidades. Petrópolis: Vozes, 1985.

FRY, Peter. Para inglês ver: identidade e política na cultura brasileira. RJ: Zahar, 1982

GAJARDO, Marcela. Pesquisa Participante: Propostas e projetos. In BRANDÃO, Carlos Rodrigues (org.) Repensando a pesquisa participante. São Paulo, Brasiliense, 1987

GAMSON, Joshua. Must identity movements self-destruct? A queer dilema. In NARDI, P. M. e SCHNEIDER, B. E. (orgs) Social perspectives ei lesbian and gay studies. London: Routledge, 1998

GARCIA, Marcos R. V. "Virgindade e iniciação sexual entre as adolescentes brasileiras. São Paulo: Arte\&Ciência, 2004

GASPAR, Maria Dulce. Garotas de Programa: Prostituição em Copacabana e Identidade Social. Rio de Janeiro: Jorge Zahar Ed, 1985.

GIUST-DESPRAIRIES, Florence. A identidade como processo, entre ligação e desprendimento. In: ZUGUEIB NETO, Jamil. Identidades e crises sociais na contemporaneidade. Curitiba: Ed. UFPR, 2005

GOFFMAN, E. Estigma: notas sobre a manipulação da identidade deteriorada. RJ: Zahar, 1982.

GORDO-LOPEZ, Angel. The Rhetorics of Gender Identity Clinics: Transsexuals and Other Boundary Objects.. In AITKEN, G. (et al.) Psychology Discourse \& Practice: From Regulation to Resistance. London, Taylor \& Francis, 1996

GREEN, James, N. Além do Carnaval: a homossexualidade masculina no Brasil do século XX. SP: Editora UNESP, 2000.

GUATTARI, F. e ROLNIK, S. Micropolítica: cartografias do desejo. Petrópolis: Vozes, 1986

GUIMARÃES, Katia e MERCHÁN-HAMANN, Egdar Comercializando fantasias: a representação social da prostituição, dilemas da profissão e a construção da cidadania. Estudos Feministas, Florianópolis, 13(3): 525-544, set-dez/2005

HAGUETTE, Teresa Maria Frota. Metodologias Qualitativas na Sociologia. Petrópolis: Vozes, 1987

HALL, Stuart. Quem precisa de identidade?. In, SILVA, Tomaz Tadeu da (org.) Identidade e diferença: a perspectiva dos estudos culturais. Petrópolis: Vozes, 2000..

HALL, Stuart. A identidade cultural na pós-modernidade. Rio de Janeiro : DP \& A, 2003.

HARAWAY, DONNA. The Promises of Monsters: A Regenerative Politics for Inappropriate/d Others. In: GROSSBERG, Lawrence, NELSON, Cary e TREICHLER, Paula A. (eds.) Cultural Studies.New York; Routledge, 1992. 
KATZ, Jonathan Ned. A Invenção da Heterossexualidade. Rio de Janeiro: Ediouro, 1996.

KEHL, Maria Rita. “Com que corpo eu vou”? Folha de S. Paulo. Caderno Mais. 30/06/2002.

KESSLER, Suzanne J \& MCKENNA, Wendy. Gender: an ethnomethodological approach. Chicago \&London, The University of Chicago Press, 1985.

KULICK, Don. Travesti : sex, gender, and culture among Brazilian transgendered prostitutes. Chicago : University of Chicago Press, 1998

LACAN, J. (1949). O estádio do espelho como formador da função do eu. In: Escritos. Jorge Zahar Editor, Rio, 1998

LAQUEUR, Thomas. Orgasm, Generation, and the Politics of Reproductive Biology. In: GALLAGHER, Catherine and LAQUEUR, Thomas (eds.) The making of the modern body: sexuality and society in the nineteenth centuty. Los Angeles, University of Califórnia Press, 1987

LAQUEUR, Thomas e GALLAGHER, Catherine The making of the modern body: sexuality and society in the nineteenth century. Los Angeles, University of Califórnia Press, 1987

LAQUEUR, Thomas. Making sex: body and gender from the greeks to Freud. Harvard University Press, 1992.

LE BRETON, David. Adeus ao Corpo: Antropologia e Sociedade. Campinas-SP, Papirus, 2003.

LEWINS, Frank. W. Transsexualism in society: a sociology of male-to-female transsexuals. South Melbourne: Macmillan Education Australia, 1995

MACRAE, Edward. Em defesa do Gueto. Novos Estudos CEBRAP, v.2, n. 1. p. 53-60, abr. 1983

MANNONI, Octave Um espanto tão intenso. RJ: Campus, 1992.

MAY, Tim. Pesquisa Social: questões, métodos e processos. Porto Alegre: Artmed, 2004.

MISSE, Michel. Malandros, marginais e vagabundos: Acumulação social da violência no Rio de Janeiro. Tese de doutorado em Sociologia. Rio de Janeiro, Instituto de Pesquisas Universitárias do Rio de Janeiro, 1999.

MOORE, Henrietta. Understanding sex and gender IN: INGOLD, Tim. (ed) Companion Encyclopedia of Antropology. London, Routledge, 1994.

MORAES, Aparecida Fonseca. Mulheres da Vila. Petrópolis, Vozes, 1996

MORIN, Edgar. Cultura de Massas no século XX: o espírito do tempo. RJ: Forense, 1969

MOTT, Luiz. Violação dos direitos humanos e assassinato de homossexuais no Brasil. Salvador: Ed. Grupo Gay da Bahia, 2000 
NANDA, Serena. Hijras: an alternativa sex and gender role in Índia. In HERDT, Gilbert. Third sex, third gender: beyond sexual dimorphism in culture and history. New Yok, Zone Books, 1994

NEWTON, Esther. Mother camp: female impersonators in America. Chicago ; London : Univ. of Chicago, 1979

NICHOLSON, Linda. Interpretando o gênero. Estudos Feministas, Florianópolis, v.8, n.2, p.9-42, 2000 .

OLIVEIRA, Neusa Maria. Damas de Paus: o jogo aberto dos travestis no espelho da mulher. Salvador: Centro Editorial e Didático da UFBA, 1994.

OLIVEIRA, Marcelo José. O lugar do travesti em desterro. Dissertação de Mestrado em Antropologia Social. Florianópolis, Universidade Federal de Santa Catarina, 1997.

OLIVEIRA, Pedro Paulo Martins. A construção social da masculinidade. Tese de Doutorado em Sociologia. São Paulo, Universidade de São Paulo, 2002

OLIVEIRA, R. D. e OLIVEIRA, M. D. Pesquisa social e ação educativa. In BRANDÃO, Carlos Rodrigues (org.) Pesquisa Participante. São Paulo, Brasiliense, 1985

ORGANIZAÇÃO MUNDIAL DA SAÚDE / FACULDADE DE SAÚDE PÚBLICA DA UNIVERSIDADE DE SÃO PAULO / ORGANIZAÇÃO PAN-AMERICANA DE SAÚDE Décima Revisão da Classificação Internacional de Doenças e de Problemas Relacionados à Saúde (CID 10) . Edição Eletrônica, 1993

PAIVA, Vera. Sexualidades adolescentes: escolaridade, gênero e o sujeito sexual. In PARKER, Richard e BARBOSA, Regina, M. Sexualidades brasileiras. RJ: Relume-Dumará: ABIA: IMS/UERJ, 1996.

PAIVA, Geraldo J. Identidade e pluralismo: identidade religiosa em adeptos brasileiros de novas religiões japonesas. Psic.: Teor. e Pesq. vol.20 no.1 Brasília Jan./Abr. 2004

PALOMINO, Erika. Babado Forte: moda, música e noite. SP: Mandarim, 1999.

PARKER, Richard.. Corpos, prazeres e paixões. SP: Best-Seller, 1992.

PARKER, Richard..A Construção da Solidariedade: AIDS, Sexualidade e Política no Brasil. Richard Parker. Rio de Janeiro: Abia, IMS-UERJ, Relume-Dumará, 1994.

PARKER, Richard.. Changing Brazilian Constructions oh Homossexuality. In: MURRAY, Stephen O. Latin American male homosexualities. Albuquerque : University of New Mexico Press, 1995.

PARKER, Richard. Abaixo do Equador. Rio de Janeiro: Record, 2002.

PASCUAL, Francisco P. F. A utilização do espaço urbano em São Paulo. Dissertação de Mestrado em Arquitetura e Urbanismo. São Paulo, Universidade de São Paulo, 1995. 
PASSERINI, Luisa. Mulheres, consumo e cultura de massas. In DUBY, Georges \& PERROT, Michelle (dir.). História das mulheres no Ocidente - Vol. 5: O Século XX. Porto : Afrontamento, 1990

PATRÍCIO. Maria Cecília. O Travesti: uma questão de gênero. Dissertação de Mestrado em Antropologia. Recife, Universidade Federal de Pernambuco, 2002.

PELUCIO, Larissa . Sexualidade, gênero e masculinidade no mundo dos T-lovers. Anais do XII Congresso Brasileiro de Sociologia, Belo Horizonte, 2005a

PELUCIO, Larissa . Na noite nem todos os gatos são pardos - notas sobre a prostituição travesti. Cadernos Pagu, Campinas, v. 25, p. 217-248, 2005b.

PELUCIO, Larissa . Toda Quebrada na Plástica - corporalidade e construção de gênero entre travestis paulistas. Campos (Curitiba), Curitiba-PR, v. 06, n. 01, p. 97-112, 2005

PERLONGHER, Néstor. O negócio do michê: prostituição viril em São Paulo. São Paulo: Brasiliense, $1987 \mathrm{a}$

PERLONGHER, Néstor. O michê é homossexual? Ou: A política da identidade. In: TRONCA, Ítalo A. (org). Foucault vivo. Campinas: Pontes, 1987b

PISCITELLI, Adriana. Apresentação: gênero no mercado do sexo. Cad. Pagu no.25 Campinas Jul/Dez. 2005

POLLAK, Michael. A homossexualidade masculina, ou: a felicidade no gueto ?. In ARIÉS, Philippe e BÉJIN, André (orgs.). Sexualidades ocidentais: contribuições para a história e para a sociologia da sexualidade. SP: Brasiliense, 1987

RAGO, M. Os prazeres da noite : prostituição e códigos da sexualidade feminina em São Paulo, 18901930. Rio de Janeiro: Paz e Terra, 1991.

RAMIRES, Francisco José. Severinos na metrópole: a negação do trabalho na cidade de São Paulo. Dissertação de Mestrado. Fac. de Filosofia, Ciências e Letras da USP, 2000

RAMALHO, João Ricardo. Mundo do crime: a ordem pelo avesso. Rio de Janeiro, Graal, 1983

RAYMOND, Janice. The Transsexual Empire: the making of the she-male. Boston: Beacon Press, 1979.

ROSCOE, Will. How to become a berdache: toward a unified analysis of gender diversity. In HERDT, Gilbert. Third sex, third gender: beyond sexual dimorphism in culture and history. New Yok, Zone Books, 1994

RUBIN, G. Thinking sex: notes for a radical theory of politics of sexuality". In Parker, Richard \& AGGLETON, P. Culture, society and sexuality - a reader. London, Taylor\&Francis, 1999.

SCHIEBINGER, Londa. Skeletons in the closet: the first illustrations of the female skeleton in eighteenth-century anatomy. IN: GALLAGHER, Catherine and LAQUEUR, Thomas (eds.) The 
making of the modern body: sexuality and society in the nineteenth centuty. Los Angeles, University of Califórnia Press, 1987

SCOTT, Joan W. Prefácio a Gender and Politics of History. Cadernos Pagu (3) 1994: pp. 11-27

SCOTT, J. Gênero: uma categoria útil para a análise histórica. Recife: SOS-Corpo, 1995.

SHAPIRO, Judith. Transsexualism: reflections on the persistence of gender and the mutability of sex. In EPSTEIN, Julia and STRAUB, Kristina (eds). Body guards :the cultural politics of gender ambiguity. New York : Routledge, 1991

SÍCOLI, Juliana Lordello e NASCIMENTO, Paulo Roberto. Promoção de saúde: concepções, princípios e operacionalização. Interface - Comunic, Saúde, Educ, v7, n12, p.101-22, fev 2003

SILVA, Hélio R. S. Travesti: a invenção do feminino Rio de Janeiro: Relume-Dumará, 1993

SILVA, Hélio R.S. Certas cariocas :travestis e vida de rua no Rio de Janeiro. Rio de Janeiro : RelumeDumará, 1996.

SIMÕES, Júlio Assis e FRANÇA, Isadora Lins. Do gueto ao mercado. IN GREEN, James, N. e TRINDADE, Ronaldo (orgs). Homossexualismo em São Paulo e outros escritos. SP: Editora UNESP, 2005.

SINGER, Paul. Economia política do trabalho. São Paulo: Hucitec, 1979

SLUGOVSKI, B. R. \& GINSBURG, G. P. Ego Identity and Explanatory Speech. In SHOTTER, J. \& GERGEN, K, ed., Texts of Identity: London, Sage Publications, 1990.

SOIHET, Rachel. Mulheres pobres e violência no Brasil urbano. IN Priore, M. (org): História das mulheres no Brasil. SP: Contexto, 1997.

SOUZA, Elza Maria e GRUNDY, Emily. Promoção da saúde, epidemiologia social e capital social: interrelações e perspectivas para a saúde pública. Cad. Saúde Pública v.20 n.5 Rio de Janeiro set./out. 2004

SPAGNOL, Antonio Sergio . O Desejo Marginal. São Paulo: Arte\&Ciência, 2001.

STOLLER, Robert J. A experiência transexual. Rio de Janeiro : Imago, 1982.

STONE, Sandy. The empire strikes back: a posttranssexual manifesto. In EPSTEIN, Julia and STRAUB, Kristina (eds). Body guards :the cultural politics of gender ambiguity. New York : Routledge, 1991

TAJFEL, Henri. Grupos Humanos e categorias sociais - estudos em Psicologia Social. Lisboa: Livros Horizonte, 1983.

TERTO JR, Veriano. No escurinho do cinema...: sociabilidade orgiástica nas tardes cariocas. Dissertação de Mestrado em Psicologia. Pontifícia Universidade Católica do Rio de Janeiro, 1989 
THIOLLENT, Michel. Metodologia da Pesquisa-ação. São Paulo, Cortez, 2002

TREVISAN, João Silvério. O espetáculo do desejo: homossexualidade e crise do masculino. In: CALDAS, Dario (org.). Homens. São Paulo: Editora SENAC São Paulo, 1997.

TREVISAN, João Silvério. Devassos no paraíso: a homossexualidade no Brasil, da Colônia à atualidade. Rio de Janeiro: Record, 2000

TRINDADE, Ronaldo. De dores e amores: transformações da homossexualidade paulistana na virada do século XX. Tese de Doutorado em Antropologia. São Paulo, Universidade de São Paulo, 2004.

TURNER, J. C. Social identification and psychological group formation. In: TAJFEL, H. The social dimension. Cambridge, Cambridge University Press, 1984. v. 2, p. 518- 38.

TYLER, Carole-Anne. Boys will be girls: the politics of gay drag. IN FUSS, Diana. Inside/out: lesbian theories, gay theories. New York; London: Routledge, 1991

VALE, Alexandre Fleming Câmara. No escurinho do cinema:: Cenas de um público Implícito. São Paulo: Annablume ; Fortaleza: Secretaria de Cultura e Desporto do Estado do Ceará, 2000.

VARELlA, Drauzio. Estação Carandiru. São Paulo : Companhia das Letras, 2003

VENCATO, Anna Paula. Fora do armário, dentro do closet: o camarim como espaço de transformação. Cad. Pagu no.24 Campinas Jan./Jun 2005

VIEIRA, Tereza Rodrigues. Mudança de sexo: aspectos médicos, psicológico, e jurídicos. São Paulo: Santos Livraria Editora, 1996.

WALKOWITZ, Judith, R. Sexualidades Perigosas. In DUBY, Georges \& Perrot, Michelle (dir.). História das mulheres no Ocidente - Vol. 4: O Século XIX. Porto : Afrontamento, 1990

WEEKS, Jeffrey . O corpo e a sexualidade. In LOURO, Guacira Lopes (org). O corpo educado: pedagogias da sexualidade. Belo Horizonte: Autêntica, 2000

WELZER-LANG, Daniel. Prostitution: Les uns, les unes et les autres. Paris: Éditions Métailié: 1994

WELZER-LANG, Daniel A construção do masculino: dominação das mulheres e homofobia $\stackrel{*}{*}$ Rev. Estud. Fem. v.9 n.2 Florianópolis 2001

WODAK, Alex. Redução de Danos e Programas de Troca de Seringas. In BASTOS, F,. I., MESQUITA, F. E MARQUES, L. F. (orgs). Troca de seringas: ciência, debate e saúde pública. Brasília, Ministério da Saúde, 1998

WOODHOUSE, Annie. Fantastic women: sex, gender and transvestism. Basingstoke: Macmillan, Education, 1989.

WOODWARD, Kathryn. Identidade e diferença: uma introdução teórica e conceitual. In: Silva, Tomaz Tadeu da (org.) Identidade e diferença: a perspectiva dos estudos culturais. Petrópolis: Vozes, 2000.. 
WORLD HEALTH ORGANIZATION. Health promotion evaluation: recommendations to policymakers.Copenhagen: European Working Group on Health Promotion Evaluation, 1998.

ZALUAR, Alba. Integração perversa: pobreza e tráfico de drogas. Rio de Janeiro: Editora FGV. 2004 